\title{
Oxyacylation of lodoalkynes: Gold(I)-Catalyzed Expeditious Access to Benzofurans
}

\author{
Paula Fernández-Canelas, Eduardo Rubio and José M. González* \\ Department of Organic and Inorganic Chemistry, University of Oviedo \\ University Institute of Organometallic Chemistry "Enrique Moles” \\ Oviedo, Spain
}

Supporting Information

Index

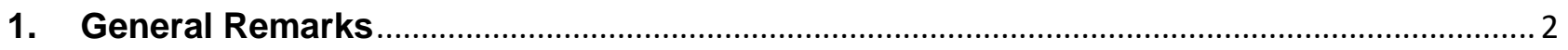

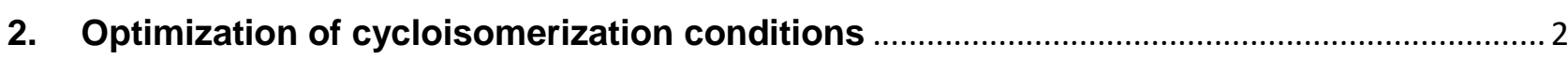

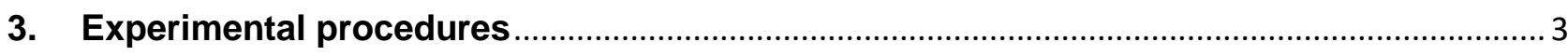

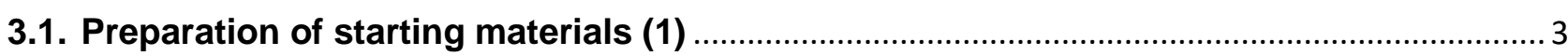

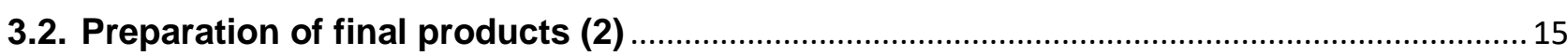

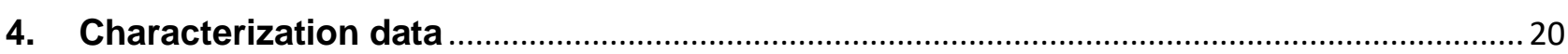

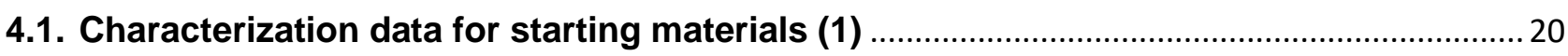

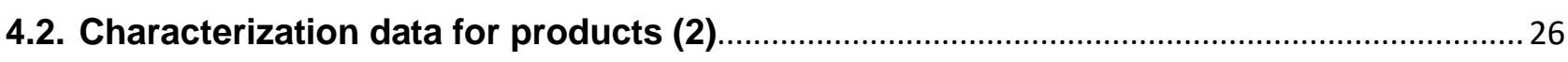

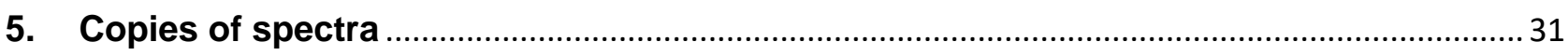

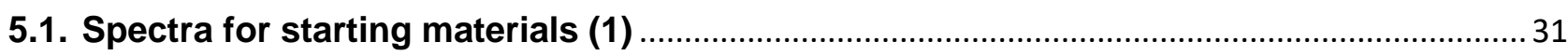

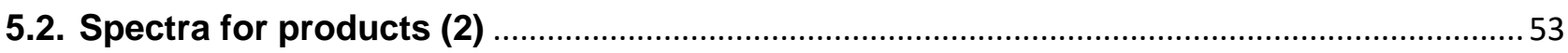

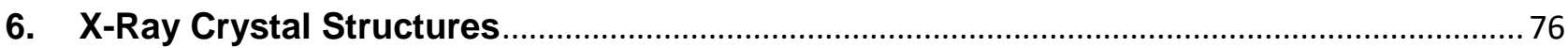

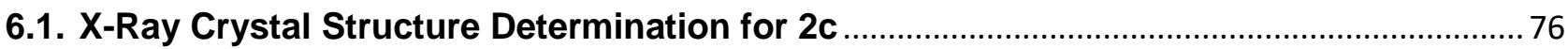

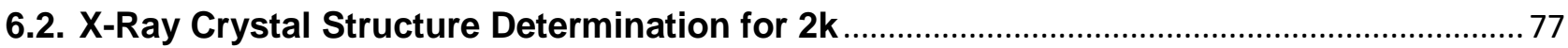

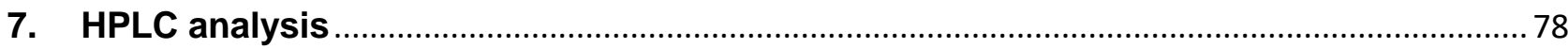

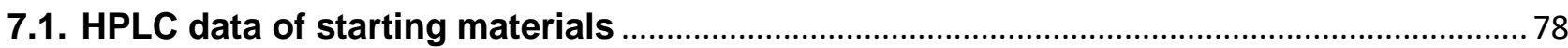

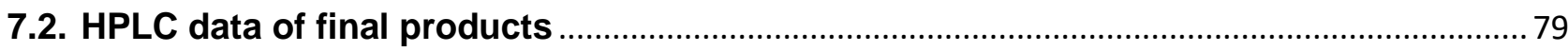

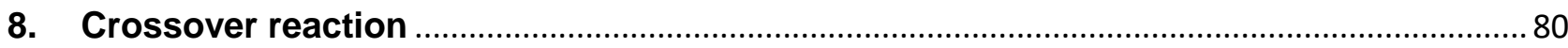

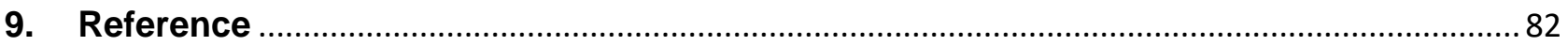




\section{General Remarks}

\section{Reactions, Solvents and Chromatography}

All reactions discussed as results of this work were carried out using oven dried glassware under an atmosphere of argon (99.999\%). 1,2-Dichloroethane (DCE), tetrahydrofuran (THF) and 1,4-dioxane were distilled from $\mathrm{CaH}_{2}$ or sodium as desiccants. Toluene was purified through an Innovative Technology System, provided with two one-meter length columns, filled with activated alumina. Commercial reagents were purchased with the best quality affordable and used without further purification unless otherwise stated. Reactions aimed to prepare compounds 2 were conducted at $80{ }^{\circ} \mathrm{C}$ in a Carousel Reaction Station from Radleys Discovery Technologies, equipped with gastight threaded caps with a valve, cooling reflux head system, and digital temperature controller.

TLC was performed on aluminum-backed plates coated with silica gel 60, with F245 indicator, and developed with $p$-anisaldehyde, phosphomolybdic acid or potassium permanganate stains. Column chromatography was carried out on silica gel (230 - 400 mesh). Solvents used in column chromatography were obtained from commercial suppliers and used without further purification.

\section{Data Collection}

${ }^{1} \mathrm{H}-\mathrm{NMR}(300,400 \mathrm{MHz})$ and ${ }^{13} \mathrm{C}-\mathrm{NMR}(75,100 \mathrm{MHz})$ spectra were measured at room temperature, on a Bruker DPX-300 MHz, Bruker AV-300 MHz, Bruker AV-400 MHz and Bruker NAV-400 MHz apparatus, with $\mathrm{CD}_{2} \mathrm{Cl}_{2}\left({ }^{1} \mathrm{H}-\mathrm{NMR} \delta=5.32,{ }^{13} \mathrm{C}-\mathrm{NMR}=53.8\right)$ as internal standard. Data are reported as follows: chemical shift $(\delta)$ in parts per million (ppm), multiplicity (s: singlet, d: doublet, t: triplet, q: quartet, sep: septet, non: nonet, dd: double doublet, dt: double triplet, m: multiplet), coupling constants $(\mathcal{J})$ in $\mathrm{Hertz}(\mathrm{Hz})$ and integration. ${ }^{13} \mathrm{C}$ multiplicities were assigned by DEPT experiments.

High resolution mass spectra (HRMS) were determined by the University of Oviedo with a high-resolution mass spectrometer (IMPACT II, BRUKER) with a quadrupole and a Time-Of-Flight (TOF) tube as analyzers, and a conventional Electrospray lon Source (ESI). The equipment uses $\mathrm{N}_{2}$ at the nebulization (2.4 Bar), and as drying gas ( $\left.250^{\circ} \mathrm{C}, 6.0 \mathrm{l} / \mathrm{min}\right)$. Mass spectra were acquired in full scan mode $(4 \mathrm{eV})$ and positive ion polarity.

Melting points (m.p.) of solid compounds were measured on a Melting Point Apparatus SMP20, Bibby Scientific, Stuart.

\section{Optimization of cycloisomerization conditions}

The optimization of the cycloisomerization reaction was carried out with the substrate 1a.<smiles>O=C(Cc1ccccc1)Oc1ccccc1C#CI</smiles>

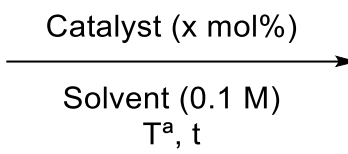<smiles>O=C(Cc1ccccc1)c1oc2ccccc2c1I</smiles>

\begin{tabular}{|c|c|c|c|c|c|c|}
\hline Entry & Catalyst & $\mathrm{mol} \%$ & Solvent & $T^{\underline{a}}$ & $\mathrm{t}$ & Yield $(\%)^{[a]}$ \\
\hline 1 & IPrAuNTf $_{2}$ & 2.5 & DCE & $80^{\circ} \mathrm{C}$ & $1 \mathrm{~h}$. & 80 \\
\hline 2 & {$\left[\mathrm{IPrAu}\left(\mathrm{CH}_{3} \mathrm{CN}\right)\right]\left[\mathrm{SbF}_{6}\right]$} & 2.5 & DCE & $80^{\circ} \mathrm{C}$ & $25 \mathrm{~min}$. & $82^{[b]}$ \\
\hline 3 & JohnPhosAuNTf 2 & 2.5 & DCE & $80^{\circ} \mathrm{C}$ & $23 \mathrm{~h}$. & 7 \\
\hline 4 & $(\mathrm{RO})_{3} \mathrm{PAuNTf}_{2}$ & 2.5 & DCE & $80^{\circ} \mathrm{C}$ & $23 \mathrm{~h}$. & 0 \\
\hline 5 & $\mathrm{AuCl}$ & 5 & DCE & $80^{\circ} \mathrm{C}$ & $23 \mathrm{~h}$. & 71 \\
\hline 6 & $\mathrm{PicAuCl}_{2}$ & 2.5 & DCE & $80^{\circ} \mathrm{C}$ & $23 \mathrm{~h}$. & 26 \\
\hline 7 & {$\left[\mathrm{IPrAu}\left(\mathrm{CH}_{3} \mathrm{CN}\right)\right]\left[\mathrm{SbF}_{6}\right]$} & 2.5 & HFIP & $50^{\circ} \mathrm{C}$ & $23 \mathrm{~h}$. & 9 \\
\hline 8 & {$\left[\mathrm{IPrAu}\left(\mathrm{CH}_{3} \mathrm{CN}\right)\right]\left[\mathrm{SbF}_{6}\right]$} & 2.5 & 1,4-Dioxane & $80^{\circ} \mathrm{C}$ & $23 \mathrm{~h}$. & - \\
\hline 9 & {$\left[\mathrm{IPrAu}\left(\mathrm{CH}_{3} \mathrm{CN}\right)\right]\left[\mathrm{SbF}_{6}\right]$} & 2.5 & THF & $80^{\circ} \mathrm{C}$ & $23 \mathrm{~h}$. & - \\
\hline 10 & {$\left[\mathrm{IPrAu}\left(\mathrm{CH}_{3} \mathrm{CN}\right)\right]\left[\mathrm{SbF}_{6}\right]$} & 2.5 & Toluene & $80^{\circ} \mathrm{C}$ & $23 \mathrm{~h}$. & 27 \\
\hline 11 & - & - & DCE & $80^{\circ} \mathrm{C}$ & $23 \mathrm{~h}$. & - \\
\hline
\end{tabular}

[a] The yield was determined from the ${ }^{1} \mathrm{H}$ NMR spectra of the corresponding crude reaction mixture upon addition of $\mathrm{CH}_{2} \mathrm{Br}_{2}$ as internal standard.

${ }^{[b]}$ Isolated yield.

The best two reaction conditions above identify (entries 1 and 2) were tested over an additional substrate. Again, the use of $\left[\mathrm{IPrAu}\left(\mathrm{CH}_{3} \mathrm{CN}\right)\right]\left[\mathrm{SbF}_{6}\right]$ gave superior experimental performance.<smiles>CC(C)=CC(=O)Oc1ccccc1C#CI</smiles>

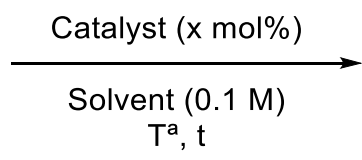<smiles>CC(C)=CC(=O)c1oc2ccccc2c1I</smiles>

\begin{tabular}{|c|c|c|c|c|c|c|}
\hline Entry & Catalyst & $\mathrm{mol} \%$ & Solvent & $\mathrm{T}^{\mathrm{a}}$ & $\mathrm{t}$ & Yield (\%) \\
\hline 1 & IPrAuNTf $_{2}$ & 2.5 & DCE & $80^{\circ} \mathrm{C}$ & $30 \mathrm{~min}$. & 63 \\
\hline 2 & {$\left[\mathrm{IPrAu}\left(\mathrm{CH}_{3} \mathrm{CN}\right)\right]\left[\mathrm{SbF}_{6}\right]$} & 2.5 & DCE & $80^{\circ} \mathrm{C}$ & $30 \mathrm{~min}$. & 81 \\
\hline
\end{tabular}




\section{Experimental procedures}

\subsection{Preparation of starting materials (1)}

\section{General Method for the synthesis of 2-(iodoethynyl)phenyl derivatives (1)}

Commercially available 2-iodophenol was used for the synthesis of compounds $\mathbf{1 a}-\mathbf{1 g}$ and $\mathbf{1 I}-\mathbf{1 p}$. 2-((trimethylsilyl)ethynyl)phenol was prepared following a Sonogashira coupling (see general method) and was next subjected to esterification and a last iodination step:

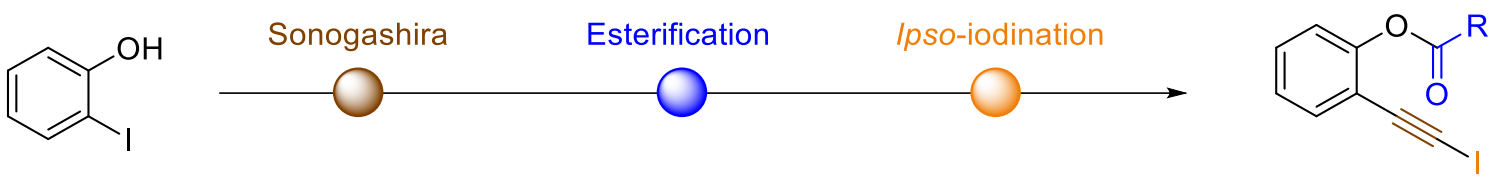

For compounds $\mathbf{1 h}-\mathbf{1 k}$ the substituted phenol was first ortho-iodinated and then subjected to the same scheme of reactions described above:

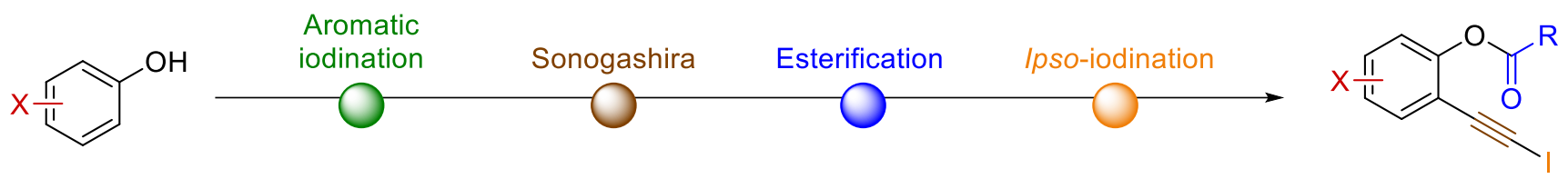

\section{General Method for the Sonogashira coupling ${ }^{1}$}

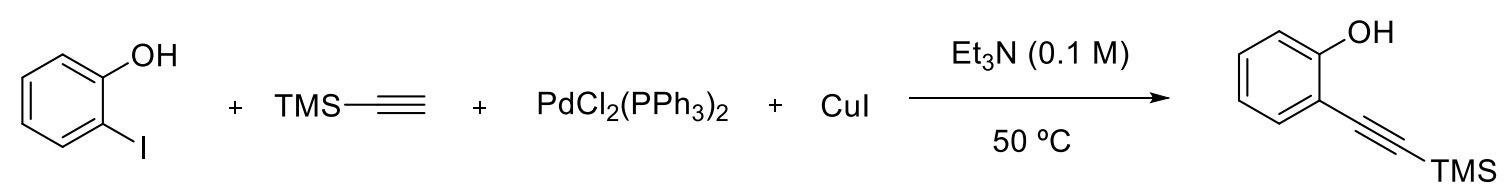

Commercial 2-iodophenol (1.00 eq., $8.40 \mathrm{mmol}, 2.00 \mathrm{~g}$ ) is added to a triethylamine solution $(0.10 \mathrm{M}$, $84.00 \mathrm{ml})$, containing bis(triphenylphosphine)palladium(II) chloride (0.02 eq., $0.17 \mathrm{mmol}, 117.9 \mathrm{mg}$ ) and copper iodide (0.02 eq., $0.17 \mathrm{mmol}, 32.0 \mathrm{mg})$. The mixture is vigorously stirred at room temperature, under argon atmosphere. After 10 minutes, trimethylsylilacetylene (1.10 eq., $9.24 \mathrm{mmol}, 1.30 \mathrm{ml}$ ) is added. The reaction is heated at $50{ }^{\circ} \mathrm{C}$ for 5 hours. Then, the heating source is retired, hexane (20 ml) is added and the mixture is filtered through celite. The solvents are evaporated and the crude is purified by column chromatography (silica gel) using a mixture of hexane:ethyl acetate (5:1) as eluent. $1.45 \mathrm{~g}$ of 2-((trimethylsilyl)ethynyl)phenol are obtained following the evaporation of the solvents (92\%).

This process is the result of an optimization of standard literature procedures for the Sonogashira coupling. The reaction proved to be robust to prepared the target alkyne from $1.30 \mathrm{~g}$ to $11 \mathrm{~g}$.

\section{Synthesis of 2-(iodoethynyl)phenyl 2-phenylacetate (1a)}

\section{- Sonogashira}

$(\text { See the General Method) })^{2}$

\section{- Esterification ${ }^{3}$}<smiles>CC#CC#Cc1ccccc1O</smiles><smiles>O=C(Cl)Cc1ccccc1</smiles>
$+\mathrm{NaH}$<smiles>CC#Cc1ccccc1OC(=O)Cc1ccccc1</smiles>

A solution of 2-[(trimethylsilyl)ethynyl]phenol (1.00 eq., $6.00 \mathrm{mmol}, 1.14 \mathrm{~g})$ in anhydrous THF $(0.77 \mathrm{M} ., 7.79 \mathrm{ml})$ is added, via cannula, over a period of 5 minutes to a solution of $\mathrm{NaH}(1.10$ eq., $6.60 \mathrm{mmol}, 158.4 \mathrm{mg})$ in anhydrous THF $(2.50 \mathrm{M}, 2.64 \mathrm{ml})$, The mixture is vigorously stirred at $0{ }^{\circ} \mathrm{C}$, under argon atmosphere. After 10 minutes, a solution of commercially available 2-phenylacetyl chloride (1.10 eq., $6.60 \mathrm{mmol}, 0.87 \mathrm{ml})$ in anhydrous THF $(1.55 \mathrm{M}, 4.40 \mathrm{ml})$ is slowly added for a period of 5 minutes, keeping the temperature at $0 \stackrel{\circ}{\circ}$. Once the addition is finished, the reaction mixture is stirred for 4 hours and 30 minutes at room temperature. Then, water $(20$ $\mathrm{ml})$ and acetic acid $(46.20 \mathrm{M}, 0.13 \mathrm{ml})$ are added and the crude extracted twice with diethyl ether. The organic layers are washed with a saturated $\mathrm{NaCl}$ solution $(3 \times 10 \mathrm{ml})$, dried over sodium sulfate, filtered and concentrated. The crude of the reaction is purified through column chromatography (silica gel, hexane:AcOEt (40:1)), obtaining $1.68 \mathrm{~g}$ of 2-[(trimethylsilyl)ethynyl]phenyl 2-phenylacetate as a yellow solid ( $91 \%$ yield). 
<smiles></smiles>

Over a solution of 2-[(trimethylsilyl)ethynyl]phenyl 2-phenylacetate (1.00 eq., $2.00 \mathrm{mmol}, 616.9 \mathrm{mg})$ in anhydrous DMF (0.20 M, $10.00 \mathrm{ml}$ ) protected from light, $N$-iodosuccinimide $(1.50$ eq., $3.00 \mathrm{mmol}, 674.9 \mathrm{mg})$ and silver nitrate $(1.10$ eq., $2.20 \mathrm{mmol}, 373.7 \mathrm{mg})$ are successively added. The resulting mixture is stirred at room temperature for 3 hours. Next, a saturated $\mathrm{NH}_{4} \mathrm{Cl}$ solution (10 ml) is added and the mixture is filtered through celite using diethyl ether as eluent. Then, the crude is extracted 3 times with diethyl ether and the organic layers washed with a $\mathrm{NaCl}$ saturated solution $(5 \times 10 \mathrm{ml})$, dried over sodium sulfate, filtered and concentrated. The crude of the reaction is purified by column chromatography (silica gel, hexane:AcOEt (20:1)), obtaining $650.4 \mathrm{mg}$ of 2-(iodoethynyl)phenyl 2-phenylacetate (1a) as a yellow solid (90\% yield).

\section{Preparation of 2-(iodoethynyl)phenyl acetate (1b)}

\section{- Sonogashira}

(See the General Method) $)^{2}$

\section{- Esterification ${ }^{5}$}<smiles>CC(=O)OC(C)=O</smiles>

Acetic anhydride (1.50 eq., $3.75 \mathrm{mmol}, 0.35 \mathrm{ml})$ and pyridine $(0.60$ eq., $1.50 \mathrm{mmol}, 0.12 \mathrm{ml})$ are successively added to a 2-[(trimethylsilyl)ethynyl]phenol (1.00 eq., $2.50 \mathrm{mmol}, 475.8 \mathrm{mg})$. The reaction is stirred vigorously for 1 hour and then, water is added and stirred for another 30 minutes. The crude is extracted 3 times with diethyl ether and the organic layers sequentially washed with a $1 \mathrm{M}$ solution of $\mathrm{HCl}$, saturated solutions of $\mathrm{NaHCO}_{3}$ and $\mathrm{NaCl}$, dried over sodium sulfate, filtered and concentrated. The crude of the reaction is purified through column chromatography (silica gel, hexane:AcOEt (40:1)), obtaining $517.4 \mathrm{mg}$ (89\% yield).

- lodoalkyne synthesis ${ }^{4}$<smiles>CC(=O)Oc1ccccc1C#CC#N</smiles>

Over a solution of 2-[(trimethylsilyl)ethynyl]phenyl acetate $(1.00$ eq., $2.23 \mathrm{mmol}, 517.4 \mathrm{mg})$ in anhydrous DMF (0.20 M, $11.00 \mathrm{ml})$ protected from light, $N$-iodosuccinimide $(1.50$ eq., $3.35 \mathrm{mmol}, 752.5 \mathrm{mg}$ ) and silver nitrate $(1.10$ eq., $2.45 \mathrm{mmol}, 416.7 \mathrm{mg})$ are successively added. The resulting mixture is stirred at room temperature for 3 hours. Next, a saturated $\mathrm{NH}_{4} \mathrm{Cl}$ solution (10 ml) is added and the mixture is filtered through celite using diethyl ether as eluent. Then, the crude is extracted 3 times with diethyl ether $(20 \mathrm{ml})$ and the organic layers washed with a $\mathrm{NaCl}$ saturated solution $(5 \times 10 \mathrm{ml})$, dried over sodium sulfate, filtered and concentrated. The crude of the reaction is purified by column chromatography (silica gel, hexane:AcOEt (10:1)), obtaining $523.9 \mathrm{mg}$ of 2-(iodoethynyl)phenyl acetate (1b) as a pale yellow solid (82\% yield).

\section{Preparation of 2-(iodoethynyl)phenyl 3-methylbutanoate (1c)}

\section{- Sonogashira}

(See the General Method) ${ }^{2}$

\section{- Esterification ${ }^{4}$}<smiles>CC#CC#Cc1ccccc1O</smiles><smiles>CC(C)CC(=O)Cl</smiles>

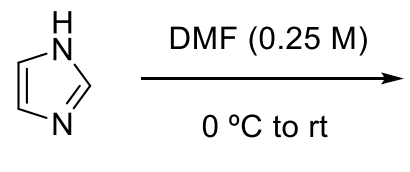<smiles>CC#Cc1ccccc1OC(=O)CC(C)C</smiles>

Imidazol (2.50 eq., $10.00 \mathrm{mmol}, 680.8 \mathrm{mg})$ and 3-methylbutanoyl chloride (1.40 eq., $5.60 \mathrm{mmol}, 0.68 \mathrm{ml})$ are successively added to a solution of 2-[(trimethylsilyl)ethynyl]phenol (1.00 eq., $4.00 \mathrm{mmol}, 761.3 \mathrm{mg})$ in anhydrous DMF $(0.25 \mathrm{M}, 16.00 \mathrm{ml})$ at $0 \stackrel{\circ}{\circ} \mathrm{C}$. The reaction is stirred vigorously for 5 minutes and then, stirring is continued at room temperature for 24 hours. $\mathrm{Next}$, a saturated $\mathrm{NH}_{4} \mathrm{Cl}$ solution is added $(15 \mathrm{ml})$ and stirred for another 20 minutes. The crude is extracted with diethyl ether $(3 \times 10 \mathrm{ml})$ and the organic layers washed with a saturated solution of $\mathrm{NaCl}(5 \times 10 \mathrm{ml})$, dried over sodium sulfate, filtered and concentrated. The crude of the reaction is purified through column chromatography (silica gel, hexane:AcOEt (80:1)), obtaining $966.7 \mathrm{mg}$ (88\% yield). 


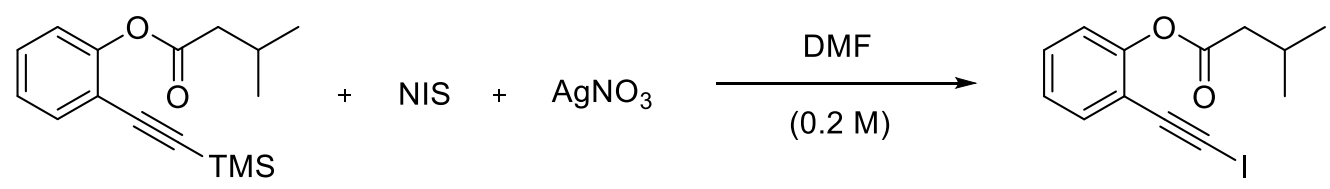

Over a solution of 2-[(trimethylsilyl)ethynyl]phenyl 3-methylbutanoate (1.00 eq., $1.50 \mathrm{mmol}, 411.7 \mathrm{mg})$ in anhydrous DMF (0.20 M, $7.50 \mathrm{ml}$ ) protected from light, $N$-iodosuccinimide $(1.50$ eq., $2.25 \mathrm{mmol}, 506.2 \mathrm{mg}$ ) and silver nitrate $(1.10$ eq., $1.65 \mathrm{mmol}, 280.3 \mathrm{mg})$ are successively added. The resulting mixture is stirred at room temperature for 3 hours. Next, a saturate $\mathrm{NH}_{4} \mathrm{Cl}$ solution (10 ml) is added and the mixture is filtered through celite using diethyl ether as eluent. Then, the crude is extracted 3 times with diethyl ether $(20 \mathrm{ml})$ and the organic layers washed with a $\mathrm{NaCl}$ saturated solution $(5 \times 10 \mathrm{ml})$, dried over sodium sulfate, filtered and concentrated. The crude of the reaction is purified by column chromatography (silica gel, hexane:AcOEt (40:1)), obtaining $275.2 \mathrm{mg}$ of 2-(iodoethynyl)phenyl 3-methylbutanoate (1c) as a yellow oil (56\% yield).

\section{Preparation of 2-(iodoethynyl)phenyl 3-phenylpropanoate (1d)}

\section{- Sonogashira}

$(\text { See the General Method) })^{2}$

\section{- Esterification ${ }^{4}$}<smiles>CC#CC#Cc1ccccc1O</smiles><smiles>O=C(Cl)CCc1ccccc1</smiles><smiles>c1c[nH]cn1</smiles><smiles>O=[R6]O[Na]</smiles><smiles>CC#Cc1ccccc1OC(=O)CCc1ccccc1</smiles>

Imidazol (2.50 eq., $7.50 \mathrm{mmol}, 510.6 \mathrm{mg}$ ) and 3-phenylpropanoyl chloride (1.40 eq., $4.20 \mathrm{mmol}, 0.62 \mathrm{ml})$ are successively added to a solution of 2-[(trimethylsilyl)ethynyl]phenol $(1.00$ eq3.00 mmol, $571.0 \mathrm{mg})$ in anhydrous DMF $(0.25 \mathrm{M}, 12.00 \mathrm{ml})$ at $0{ }^{\circ} \mathrm{C}$. The reaction is stirred vigorously for 5 minutes and then, stirring is continued at room temperature for 14 hours. Next, a saturated $\mathrm{NH}_{4} \mathrm{Cl}$ solution is added $(10 \mathrm{ml})$ and stirred for another 20 minutes. The crude is extracted with diethyl ether $(3 \times 10 \mathrm{ml})$ and the organic layers washed with a saturated solution of $\mathrm{NaCl}(5 \times 10 \mathrm{ml})$, dried over sodium sulfate, filtered and concentrated. The crude of the reaction is purified through column chromatography (silica gel, hexane:AcOEt (80:1)), obtaining $435.9 \mathrm{mg}$ of the product (45\% yield).

\section{- lodoalkyne synthesis ${ }^{4}$}<smiles>CC(C)(C)C#Cc1ccccc1OC(=O)CCc1ccccc1</smiles>

Over a solution of 2-[(trimethylsilyl)ethynyl]phenyl 3-phenylpropanoate (1.00 eq., $1.17 \mathrm{mmol}, 377.5 \mathrm{mg})$ in anhydrous DMF (0.20 M, $5.85 \mathrm{ml})$ protected from light, $N$-iodosuccinimide $(1.50 \mathrm{eq}, 1.76 \mathrm{mmol}, 394.8 \mathrm{mg})$ and silver nitrate $(1.10$ eq., $1.29 \mathrm{mmol}, 218.6 \mathrm{mg})$ are successively added. The resulting mixture is stirred at room temperature for 3 hours. Next, a saturated $\mathrm{NH}_{4} \mathrm{Cl}$ solution $(5 \mathrm{ml})$ is added and the mixture is filtered through celite using diethyl ether as eluent. Then, the crude is extracted 3 times with diethyl ether and the organic layers washed with a NaCl saturated solution $(5 \times 10 \mathrm{ml})$, dried over sodium sulfate, filtered and concentrated. The crude of the reaction is purified by column chromatography (silica gel, hexane:AcOEt (80:1)), obtaining $377.2 \mathrm{mg}$ of 2-(iodoethynyl)phenyl 3-phenylpropanoate (1d) as a yellow oil (86\% yield).

\section{Preparation of 2-(iodoethynyl)phenyl benzoate (1e)}

\section{- Sonogashira}

(See the General Method) ${ }^{2}$

\section{- Esterification ${ }^{6}$}<smiles>CC(C)(C)NC(=O)c1ccccc1ON=O</smiles> 
2-[(trimethylsilyl)ethynyl]phenol (1.00 eq, $5.00 \mathrm{mmol}, 951.6 \mathrm{mg})$ is added to a solution of $\mathrm{NaOH}(10 \%$ in water) and the mixture is cooled to $0^{\circ} \mathrm{C}$. A solution of tetrabutylammonium chloride $(0.10$ eq., $0.50 \mathrm{mmol}, 139.0 \mathrm{mg})$ in anhydrous methylene chloride $(0.30 \mathrm{M}$, $1.70 \mathrm{ml}$ ) is prepared in another flask at $0 \stackrel{\circ}{\circ}$. Then, this solution is added to the flask containing the alkyne. Next, a solution of benzoyl chloride $(1.00$ eq., $5.00 \mathrm{mmol}, 0.58 \mathrm{ml})$ in anhydrous dichloromethane $(1.00 \mathrm{M}, 5.00 \mathrm{ml})$ is prepared. The later solution is added to the first one and the reaction is stirred vigorously for 5 minutes, keeping the temperature at $0{ }^{\circ} \mathrm{C}$. ice water $(5 \mathrm{ml})$ is then added, and the resulting mixture is stirred for additional 35 minutes. Following, the mixture is extracted with diethyl ether, the organic layers washed with a saturated $\mathrm{NaCl}$ solution $(3 \times 5 \mathrm{ml})$. The mixture is dried over sodium sulfate, filtered and concentrated. The crude of the reaction is purified through column chromatography (silica gel, hexane:AcOEt (80:1)), obtaining 866.9 mg of the product (78\% yield).

\section{- lodoalkyne synthesis ${ }^{7}$}

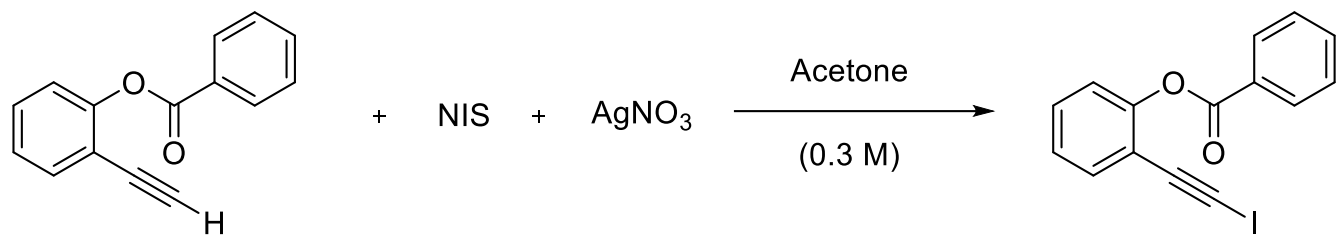

Over a solution of 2-ethynylphenyl benzoate (1.00 eq., $3.82 \mathrm{mmol}, 849.2 \mathrm{mg})$ in acetone $(0.30 \mathrm{M}, 12.73 \mathrm{ml})$ protected from light, $\mathrm{N}$-iodosuccinimide $(1.20$ eq., $4.58 \mathrm{mmol}, 1.03 \mathrm{~g})$ and silver nitrate $(0.10 \mathrm{eq}$., $0.38 \mathrm{mmol}, 64.9 \mathrm{mg})$ are successively added. The resulting mixture is stirred at room temperature for 3 hours. Next, hexane $(8 \mathrm{ml})$ is added and the mixture is filtered through celite using hexane as eluent. Then, the crude is concentrated and purified by column chromatography (silica gel, hexane:AcOEt (80:1)), obtaining $1.16 \mathrm{~g}$ of 2-(iodoethynyl)phenyl benzoate (1e) as a brown oil ( $87 \%$ yield).

\section{Preparation of 2-(iodoethynyl)phenyl 4-methoxybenzoate (1f)}

\section{- Sonogashira}

$(\text { See the General Method })^{2}$

\section{- Esterification;Error! Marcador no definido.}<smiles>COc1ccc(C(=O)Oc2ccccc2C#CC(=O)NO[N+](Cl)(Cl)C(C)(C)C)cc1</smiles>

2-[(trimethylsilyl)ethynyl]phenol (1.00 eq, $3.00 \mathrm{mmol}, 570.9 \mathrm{mg})$ is added over a solution of $\mathrm{NaOH}(10 \%$ in water) and the mixture is cooled to $0 \stackrel{\circ}{\circ}$. A solution of tetrabutylammonium chloride $(0.10$ eq., $0.30 \mathrm{mmol}, 83.4 \mathrm{mg})$ in anhydrous methylene chloride $(0.30 \mathrm{M}$, $1.00 \mathrm{ml}$ ) is prepared, in another flask at $0{ }^{\circ} \mathrm{C}$. Then, this solution is added to the flask containing the alkyne. Next, a solution of 4-methoxybenzoyl chloride $(1.00$ eq., $3.00 \mathrm{mmol}, 0.41 \mathrm{ml})$ in ahydrous dichloromethane $(1.00 \mathrm{M}, 3.00 \mathrm{ml})$ is prepared. The later solution is added to the first one and the reaction is stirred vigorously for 5 minutes, keeping the temperature at $0 \stackrel{\circ}{\circ} \mathrm{C}$. ice water $(3 \mathrm{ml})$ is then added, and the resulting mixture is stirred for additional 35 minutes. Following, the mixture is extracted with diethyl ether ( $3 \times$ $10 \mathrm{ml})$, the organic layers washed with a saturated $\mathrm{NaCl}$ solution $(3 \times 5 \mathrm{ml})$. The mixture is dried over sodium sulfate, filtered and concentrated. The crude of the reaction is purified through column chromatography (silica gel, hexane:AcOEt $(40: 1$ to $20: 1)$ ), obtaining $664.0 \mathrm{mg}$ of the product ( $88 \%$ yield).

\section{- lodoalkyne synthesis ${ }^{7}$}<smiles>COc1ccc(C(=O)Oc2ccccc2C#CI)cc1</smiles>

Over a solution of 2-ethynylphenyl 4-methoxybenzoate (1.00 eq., $1.63 \mathrm{mmol}, 411.2 \mathrm{mg})$ in acetone $(0.30 \mathrm{M}, 5.43 \mathrm{ml})$ protected from light, $N$-iodosuccinimide $(1.20$ eq., $1.96 \mathrm{mmol}, 440.0 \mathrm{mg})$ and silver nitrate $(0.10$ eq., $0.16 \mathrm{mmol}, 27.7 \mathrm{mg})$ are successively added. The resulting mixture is stirred at room temperature for 3 hours. Next, hexane $(5 \mathrm{ml})$ is added and the mixture is filtered through celite using hexane as eluent. Then, the crude is concentrated and purified by column chromatography (silica gel, hexane:AcOEt (10:1)), obtaining 568.0 mg of 2-(iodoethynyl)phenyl 4-methoxybenzoate (1f) as a white solid (92\% yield).

\section{Synthesis of 2-(iodoethynyl)phenyl 4-bromobenzoate (1g)}

\section{- Sonogashira}

(See the General Method) ${ }^{2}$ 


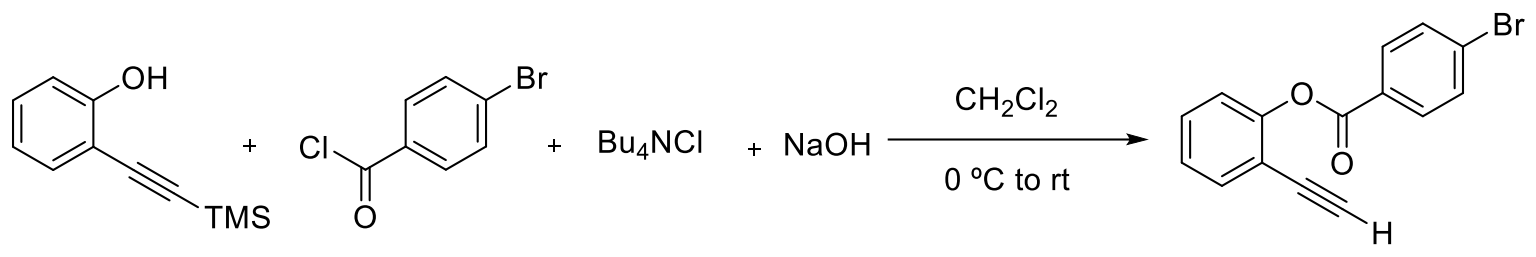

2-[(trimethylsilyl)ethynyl]phenol $(1.00 \mathrm{eq}, ., 3.00 \mathrm{mmol}, 570.9 \mathrm{mg})$ is added to a solution of $\mathrm{NaOH}(10 \%$ in water) and the mixture is cooled to $0 \stackrel{\circ}{\circ}$. A solution of tetrabutylammonium chloride $(0.10$ eq., $0.30 \mathrm{mmol}, 83.4 \mathrm{mg})$ in anhydrous methylene chloride $(0.30 \mathrm{M}$, $1.00 \mathrm{ml}$ ) is prepared in another flask at $0{ }^{\circ} \mathrm{C}$. Then, this is added to the flask containing the alkyne. Next, a solution of 4-bromobenzoyl chloride (1.00 eq., $3.00 \mathrm{mmol}, 658.4 \mathrm{mg})$ in ahydrous dichloromethane $(1.00 \mathrm{M}, 3.00 \mathrm{ml})$ is prepared. The later solution is added to the first one and the reaction is stirred vigorously for 5 minutes, keeping the temperature at $0{ }^{\circ} \mathrm{C}$. ice water $(3 \mathrm{ml})$ is then added, and the resulting mixture is stirred for additional 35 minutes. Following, the mixture is extracted with diethyl ether $(3 \times$ $10 \mathrm{ml})$, the organic layers washed with a saturated $\mathrm{NaCl}$ solution $(3 \times 5 \mathrm{ml})$ The mixture is dried over sodium sulfate, filtered and concentrated. The crude of the reaction is purified through column chromatography (silica gel, hexane:AcOEt (40:1)), obtaining $587.9 \mathrm{mg}$ of 2-ethynylphenyl 4-bromobenzoate (88\% yield).

\section{- lodoalkyne synthesis ${ }^{7}$}<smiles></smiles>

Over a solution of 2-ethynylphenyl 4-bromobenzoate ( 1.00 eq., $1.88 \mathrm{mmol}, 566.1 \mathrm{mg})$ in acetone $(0.30 \mathrm{M}, 6.26 \mathrm{ml})$ protected from light, $N$-iodosuccinimide (1.20 eq., $2.26 \mathrm{mmol}, 507.5 \mathrm{mg})$ ) and silver nitrate $(0.10$ eq., $0.19 \mathrm{mmol}, 31.9 \mathrm{mg})$ are successively added. The resulting mixture is stirred at room temperature for 3 hours. Next, hexane $(6 \mathrm{ml})$ is added and the mixture is filtered through celite using hexane as eluent. Then, the crude is concentrated and purified by column chromatography (silica gel, hexane:AcOEt (20:1)), obtaining $754.7 \mathrm{mg}$ of 2-(iodoethynyl)phenyl 4-bromobenzoate (19) a white solid (94\% yield).

\section{Synthesis of 4-chloro-2-(iodoethynyl)phenyl benzoate (1h)}

\section{- Aromatic lodination ${ }^{4}$}<smiles>Oc1ccc(Cl)cc1</smiles><smiles>CCOCCOCCOCC</smiles><smiles>Oc1ccc(Cl)cc1I</smiles>

To a solution of 4-chlorophenol (1.00 eq., $24.00 \mathrm{mmol}, 3.10 \mathrm{~g})$ in anhydrous dichloromethane $(500 \mathrm{ml})$ at $0 \stackrel{\circ}{\circ}$, a solution of tetrafluoroboric acid diethyl ether complex $(0.92$ eq., $22.00 \mathrm{mmol}, 3.00 \mathrm{ml})$ and iodonium bispyridine tetrafluoroborate $(0.83 \mathrm{eq}$., $20.00 \mathrm{mmol}, 7.40 \mathrm{~g}$ ) are added. The addition of this last reagent is carried out slowly over a period of 30 minutes. The mixture is allowed to reach room temperature and stirred for 60 minutes. Then, a solution of sodium thiosulfate $(5 \% \mathrm{w} / \mathrm{v})(100 \mathrm{ml})$ is added, the mixture is concentrated until $100 \mathrm{ml}$ approximately. The organic layer is separated and washed successively with $\mathrm{HCl}(1 \mathrm{M}, 100 \mathrm{ml})$, sodium thiosulfate $(5 \% \mathrm{w} / \mathrm{v})(100 \mathrm{ml})$ and a saturated $\mathrm{NaCl}$ solution $(100 \mathrm{ml})$. Then, it is dried over sodium sulfate, filtered through celite using hexane:ethyl acetate (2:1) as eluent, obtaining the product that is used for the next step without further purification.

\section{- Sonogashira ${ }^{4}$}

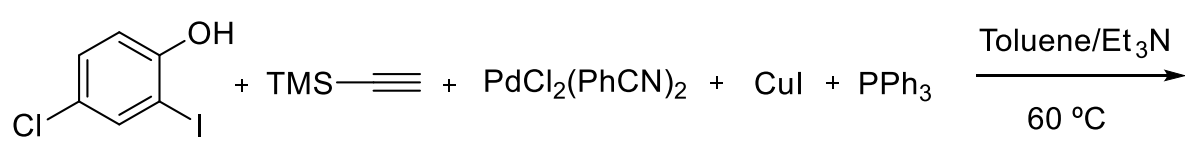<smiles>CC#Cc1cc(Cl)ccc1O</smiles>

To a solution of 4-chloro-2-iodophenol (1.00 eq., $20.00 \mathrm{mmol}, 5.09 \mathrm{~g})$ in $50 \mathrm{ml}$ of a mixture of toluene: dry trimethylamine (4:1) under argon atmosphere at room temperature, bis(benzonitrile)palladium (II) chloride (0.02 eq., $0.40 \mathrm{mmol}, 150.0 \mathrm{mg}$ ), triphenylphosphine (0.06 eq., $1.20 \mathrm{mmol}, 310.0 \mathrm{mg})$, copper iodide $(0.02$ eq., $0.40 \mathrm{mmol}, 80.0 \mathrm{mg})$ and trimethylsylilacetylene $(2.00$ eq., $40.00 \mathrm{mmol}$, $5.60 \mathrm{ml}$ ) are sequentially added in 5 minutes intervals between each addition. The reaction is allowed to evolve for 14 hours at $60 \stackrel{\circ}{ } \mathrm{C}$ Then, the heat source is removed, the reaction reaches the room temperature and a saturated solution of ammonium chloride (10 $\mathrm{ml}$ ) is added, the mixture is then filtered through celite using ethyl acetate $(50 \mathrm{ml})$ as eluent. The mixture is then concentrated and purified through column chromatography (silica gel, hexane:AcOEt (40:1 to 20:1 gradient)), obtaining $3.11 \mathrm{~g}$ of the product (69\%). 
<smiles>CC(C)(C)[N+](Cl)(Cl)c1ccccc1C(=O)Cl</smiles>

4-chloro-2-[(trimethylsilyl)ethynyl]phenol (1.00 eq., $2.00 \mathrm{mmol}, 449.5 \mathrm{mg})$ is added to a solution of $\mathrm{NaOH}(10 \%$ in water) and the mixture is cooled to $0 \stackrel{\circ}{\circ}$. A solution of tetrabutylammonium chloride $(0.10$ eq., $0.20 \mathrm{mmol}, 55.6 \mathrm{mg})$ in anhydrous methylene chloride $(0.30 \mathrm{M}, 0.70 \mathrm{ml})$ is prepared in another flask also at $0{ }^{\circ} \mathrm{C}$. Then, this solution is added to the flask containing the alkyne. Next, a solution of benzoyl chloride $(1.00$ eq., $2.00 \mathrm{mmol}, 0.23 \mathrm{ml})$ in ahydrous dichloromethane $(1.00 \mathrm{M}, 2.00 \mathrm{ml})$ is prepared. The later solution is added to the first one and the reaction is stirred vigorously for 5 minutes, keeping the temperature at $0{ }^{\circ} \mathrm{C}$. ice water $(3 \mathrm{ml})$ is then added, and the resulting mixture is stirred for additional 60 minutes. Following, the mixture is extracted with diethyl ether ( $3 \times$ $10 \mathrm{ml})$, the organic layers washed with a saturated $\mathrm{NaCl}$ solution $(3 \times 5 \mathrm{ml})$. The mixture is dried over sodium sulfate, filtered and concentrated. The crude of the reaction is purified through column chromatography (silica gel, hexane:AcOEt (20:1)), obtaining $384.1 \mathrm{mg}$ of 4-chloro-2-ethynylphenyl benzoate (75 \% yield).

\section{- lodoalkyne synthesis ${ }^{7}$}

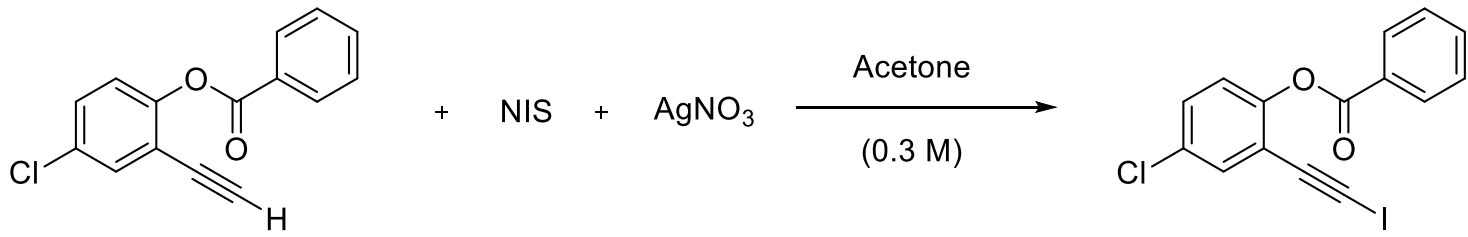

Over a solution of 4-chloro-2-ethynylphenyl benzoate $(1.00$ eq., $1.50 \mathrm{mmol}, 384.1 \mathrm{mg})$ in acetone $(0.30 \mathrm{M}, 5.00 \mathrm{ml})$ protected from light, $N$-iodosuccinimide (1.20 eq., $1.80 \mathrm{mmol}, 404.9 \mathrm{mg})$ and silver nitrate $(0.10$ eq., $0.16 \mathrm{mmol}, 25.5 \mathrm{mg})$ are successively added. The resulting mixture is stirred at room temperature for 3 hours. Next, hexane $(5 \mathrm{ml})$ is added and the mixture is filtered through celite using hexane as eluent. Then, the crude is concentrated and purified by column chromatography (silica gel, hexane:AcOEt (20:1)), obtaining $526.0 \mathrm{mg}$ 4-chloro-2-(iodoethynyl)phenyl benzoate (1h) as a pale yellow solid (92 \% yield).

\section{Synthesis of ethyl 4-(benzoyloxy)-3-(iodoethynyl)benzoate (1i)}

\section{- Aromatic lodination ${ }^{4}$}<smiles>CCOC(=O)c1ccc(O)c(I)c1</smiles>

To a solution of ethyl 4-hydroxy benzoate (1.00 eq., $24.00 \mathrm{mmol}, 4.00 \mathrm{~g})$ in dichloromethane $(500 \mathrm{ml})$ at $0{ }^{\circ} \mathrm{C}$, a solution of tetrafluoroboric acid diethyl ether complex $(0.92$ eq., $22.00 \mathrm{mmol}, 3.00 \mathrm{ml})$ and iodonium bispyridine tetrafluoroborate $(0.83 \mathrm{eq}$., 20.00 $\mathrm{mmol}, 7.40 \mathrm{~g}$ ) are added. The addition of this last reagent is carried out slowly over a period of 30 minutes. The mixture is allowed to reach room temperature and stirred for 60 minutes. Then, a solution of sodium thiosulfate $(5 \% \mathrm{w} / \mathrm{v})(100 \mathrm{ml})$ is added, the mixture is concentrated until $100 \mathrm{ml}$ approximately. The mixture is washed successively with $\mathrm{HCl}(1 \mathrm{M}, 100 \mathrm{ml})$, sodium thiosulfate $(5 \% \mathrm{w} / \mathrm{v})$ $(100 \mathrm{ml})$ and a saturated $\mathrm{NaCl}$ solution $(100 \mathrm{ml})$. Then, it is dried over sodium sulfate, filtered through celite using hexane:AcOEt $(1: 1)$ as eluent, obtaining the product that is used for the next step without further purification.

\section{- Sonogashira ${ }^{4}$}

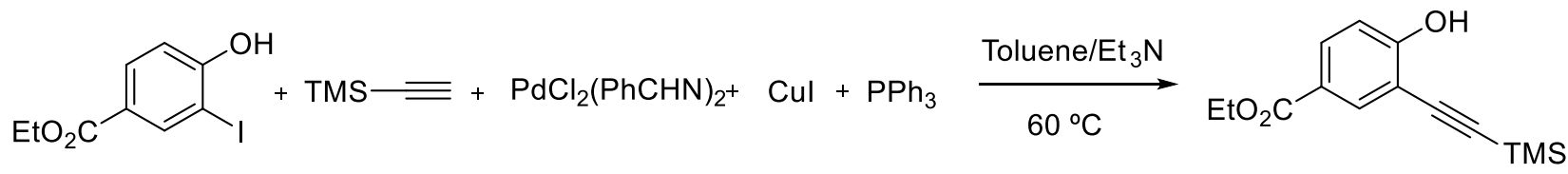

To a solution of ethyl 4-hydroxy-3-iodobenzoate (1.00 eq., $20.00 \mathrm{mmol}, 5.84 \mathrm{~g}$ ) in $50 \mathrm{ml}$ of a mixture of toluene:dry trimethylamine (4:1) under argon atmosphere at room temperature, bis(benzonitrile)palladium (II) chloride (0.02 eq., $0.40 \mathrm{mmol}, 150.0 \mathrm{mg}$ ), triphenylphosphine $(0.06$ eq., $1.20 \mathrm{mmol}, 310.0 \mathrm{mg}$ ), copper iodide $(0.02$ eq., $0.40 \mathrm{mmol}, 80.0 \mathrm{mg})$ and trimethylsylilacetylene (2.00 eq., $40.00 \mathrm{mmol}, 5.60 \mathrm{ml}$ ) are sequentially added in 5 minutes intervals between each addition. The reaction is allowed to evolve for 14 hours at $60^{\circ} \mathrm{C}$. Then, the heat source is removed, the reaction reaches the room temperature and a saturated solution of ammonium chloride $(10 \mathrm{ml})$ is added, the mixture is then filtered through celite using ethyl acetate $(50 \mathrm{ml})$ as eluent. The mixture is then concentrated and purified through column chromatography (silica gel, hexane:AcOEt (20:1 to 10:1 gradient)), obtaining the product in $85 \%$ yield. 


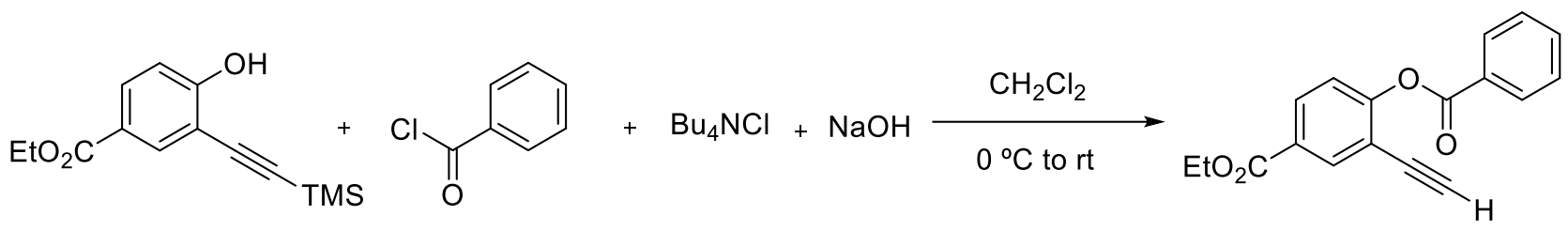

ethyl 4-hydroxy-3-[(trimethylsilyl)ethynyl]benzoate (1.00 eq., $2.00 \mathrm{mmol}, 524.8 \mathrm{mg})$ is added to a solution of $\mathrm{NaOH}(10 \%$ in water) and the mixture is cooled to $0{ }^{\circ} \mathrm{C}$. A solution of tetrabutylammonium chloride $(0.10$ eq., $0.20 \mathrm{mmol}, 55.6 \mathrm{mg})$ in anhydrous methylene chloride $(0.30 \mathrm{M}, 0.70 \mathrm{ml})$ is prepared in another flask, also at $0{ }^{\circ} \mathrm{C}$. Then, this solution is added is added to the flask containing the alkyne. Next, a solution benzoyl chloride $(1.00$ eq., $2.00 \mathrm{mmol}, 0.23 \mathrm{ml})$ in ahydrous dichloromethane $(1.00 \mathrm{M}, 2.00 \mathrm{ml})$ is prepared. The later solution is added to the first one and the reaction is stirred vigorously for 5 minutes, keeping the temperature at $0 \stackrel{\circ}{ } \mathrm{C}$. ice water $(3 \mathrm{ml})$ is then added, and the resulting mixture is stirred for additional 20 minutes. Following, the mixture is extracted with diethyl ether $(3 \times 10 \mathrm{ml})$, the organic layers washed with a saturated $\mathrm{NaCl}$ solution $(3 \times 5 \mathrm{ml})$. The mixture is dried over sodium sulfate, filtered and concentrated. The crude of the reaction is purified through column chromatography (silica gel, hexane:AcOEt (20:1)), obtaining $400.3 \mathrm{mg}$ of the product ( $68 \%$ yield).

\section{- lodoalkyne synthesis ${ }^{7}$}<smiles>CCOC(=O)c1ccc(OC(=O)C#Cc2cc(C(=O)OCC)ccc2OC(=O)c2ccccc2)c(C#CI)c1</smiles>

Over a solution ethyl 4-(benzoyloxy)-3-ethynylbenzoate $(1.00$ eq., $1.33 \mathrm{mmol}, 392.7 \mathrm{mg})$ in acetone $(0.30 \mathrm{M}, 4.43 \mathrm{ml})$ protected from light, $N$-iodosuccinimide (1.20 eq., $1.60 \mathrm{mmol}, 359.0 \mathrm{mg})$ and silver nitrate $(0.10$ eq., $0.13 \mathrm{mmol}, 22.6 \mathrm{mg})$ are successively added. The resulting mixture is stirred at room temperature for 3 hours. Next, hexane $(5 \mathrm{ml})$ is added and the mixture is filtered through celite using hexane as eluent. Then, the crude is concentrated and purified by column chromatography (silica gel, hexane:AcOEt (20:1)), obtaining $316.8 \mathrm{mg}$ of ethyl 4-(benzoyloxy)-3-(iodoethynyl)benzoate (1i) as a pale yellow solid (57\% yield).

\section{Synthesis of 2-(iodoethynyl)-4-methylphenyl benzoate (1i)}

\section{- Aromatic lodination ${ }^{8}$}

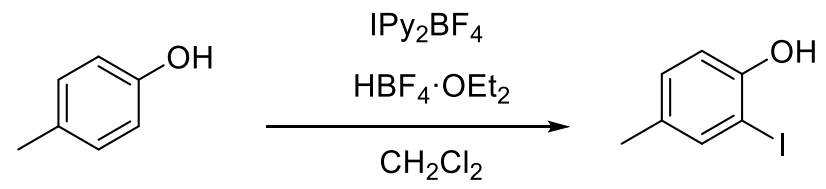

To a solution of p-cresol (1.00 eq., $20 \mathrm{mmol}, 2.09 \mathrm{ml})$ in dichloromethane $(0.2 \mathrm{M}, 100 \mathrm{ml})$, a solution of tetrafluoroboric acid diethyl ether complex (1.10 eq., $22.00 \mathrm{mmol}, 3.02 \mathrm{ml})$ and iodonium bispyridine tetrafluoroborate $(1.00 \mathrm{eq} ., 20.00 \mathrm{mmol}, 7.45 \mathrm{~g})$ are added. The addition of this last reagent is carried out slowly over a period of 30 minutes. The mixture is stirred for 60 minutes. Then, a solution of sodium thiosulfate $(5 \% \mathrm{w} / \mathrm{v})(100 \mathrm{ml})$ is added, and extracted with dichloromethane $(3 \times 100 \mathrm{ml})$, the organic layers are dried over sodium sulfate, filtered and concentrated. The residue is purified through column chromatography (silica gel, hexane:AcOEt (20:1)), obtaining $2.90 \mathrm{~g}$ of 2-iodo-4-methylphenol (62\%).

\section{- Sonogashira}

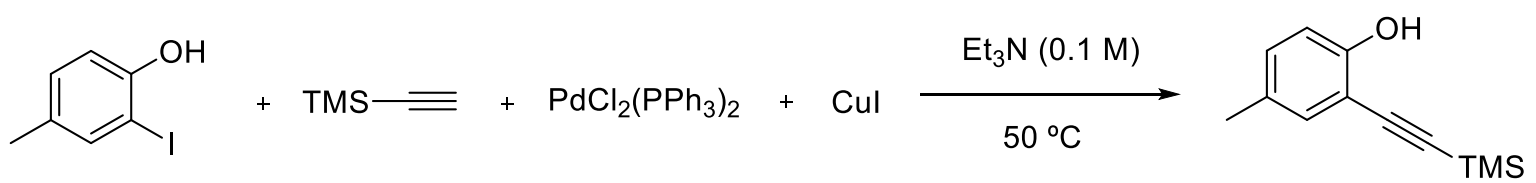

A solution of bis(triphenylphosphine)palladium (II) chloride $(0.02$ eq., $0.19 \mathrm{mmol}, 134.1 \mathrm{mg})$ and copper iodide $(0.02 \mathrm{eq} ., 0.19 \mathrm{mmol}$, $36.4 \mathrm{mg})$ in trimethylamine $(95.30 \mathrm{ml})$ is prepared under argon atmosphere at room temperature. To this solution, 2 -iodo-4methylphenol (1.00 eq., $9.53 \mathrm{mmol}, 2.23 \mathrm{~g})$. is added and, after 10 minutes of stirring, trimethylsylilacetylene $(1.10 \mathrm{eq} ., 10.49 \mathrm{mmol}$, $1.48 \mathrm{ml}$ ) is added whit vigorous shaking and the reaction is allowed to evolve for 6 hours at $50^{\circ} \mathrm{C}$. Then, hexane is added (20 ml) and the crude is filtered through celite and purified through column chromatography (silica gel, hexane:AcOEt (20:1)), obtaining 1.83 g of 4-methyl-2-[(trimethylsilyl)ethynyl]phenol (94\%). 
<smiles>CC#Cc1cc(C)ccc1O</smiles><smiles>O=C(Cl)c1ccccc1</smiles><smiles>O=[N+]([O-])[Mg][Mg]</smiles><smiles>C#Cc1cc(C)ccc1OC(=O)c1ccccc1</smiles>

4-methyl-2-[(trimethylsilyl)ethynyl]phenol (1.00 eq., $1.50 \mathrm{mmol}, 393.6 \mathrm{mg})$ is added to a solution of $\mathrm{NaOH}(10 \%$ in water) and the mixture is cooled to $0 \stackrel{\circ}{\circ}$. A solution of tetrabutylammonium chloride $(0.10$ eq., $0.15 \mathrm{mmol}, 41.7 \mathrm{mg})$ in anhydrous methylene chloride $(0.30 \mathrm{M}, 0.50 \mathrm{ml})$ is prepared in another flask also at $0{ }^{\circ} \mathrm{C}$. Then, this solution is added is added to the flask containing the alkyne. Following, a solution benzoyl chloride $(1.00$ eq., $1.50 \mathrm{mmol}, 0.17 \mathrm{ml})$ in ahydrous dichloromethane $(1.00 \mathrm{M}, 1.50 \mathrm{ml})$ is prepared. The later solution is added to the first one and the reaction is stirred vigorously for 5 minutes, keeping the temperature at $0 \stackrel{\circ}{\circ} \mathrm{C}$. ice water $(3 \mathrm{ml})$ is then added, and the resulting mixture is stirred for additional 60 minutes. Next, the mixture is extracted with diethyl ether $(3 \times$ $10 \mathrm{ml})$, the organic layers washed with a saturated $\mathrm{NaCl}$ solution $(3 \times 5 \mathrm{ml})$. The mixture is dried over sodium sulfate, filtered and concentrated.The crude of the reaction is purified through column chromatography (silica gel, hexane:AcOEt (20:1)), obtaining $390.0 \mathrm{mg}$ de 2-ethynyl-4-methylphenyl benzoate (97\% yield).

\section{- lodoalkyne synthesis ${ }^{7}$}<smiles>C#Cc1cc(C)ccc1OC(=O)c1ccccc1</smiles>

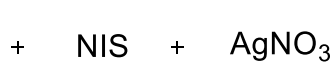<smiles>Cc1ccc(OC(=O)c2ccccc2)c(C#CI)c1</smiles>

Over a solution of 2-ethynyl-4-methylphenyl benzoate $(1.00$ eq., $1.65 \mathrm{mmol}, 389.8 \mathrm{mg})$ in acetone $(0.30 \mathrm{M}, 5.50 \mathrm{ml})$ protected from light, $N$-iodosuccinimide (1.20 eq., $1.98 \mathrm{mmol}, 445.4 \mathrm{mg})$ and silver nitrate $(0.10$ eq., $0.16 \mathrm{mmol}, 28.0 \mathrm{mg})$ are successively added. The resulting mixture is stirred at room temperature for 3 hours. Next, hexane $(5 \mathrm{ml})$ is added and the mixture is filtered through celite using hexane as eluent. Then, the crude is concentrated and purified by column chromatography (silica gel, hexane:AcOEt (20:1)), obtaining $513.9 \mathrm{mg}$ of 2-(iodoethynyl)-4-methylphenyl benzoate (1j) as a white solid (86 \% yield).

\section{Synthesis of 2-(iodoethynyl)-4,6-dimethylphenyl benzoate (1k)}

\section{- Aromatic lodination ${ }^{8}$}<smiles>Cc1ccc(O)c(C)c1</smiles>

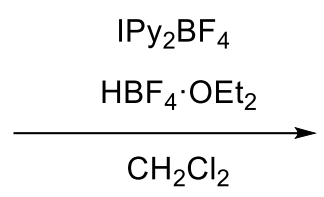<smiles>Cc1cc(C)c(O)c(I)c1</smiles>

To a solution of 2,4-dimethylphenol (1.00 eq., $20 \mathrm{mmol}, 2.42 \mathrm{ml})$ in dichloromethane $(0.18 \mathrm{M}, 108 \mathrm{ml})$, a solution of tetrafluoroboric acid diethyl ether complex (1.10 eq., $22 \mathrm{mmol}, 3.02 \mathrm{ml})$ and iodonium bispyridine tetrafluoroborate $(1.00 \mathrm{eq} ., 20 \mathrm{mmol}, 7.45 \mathrm{~g})$ are added. The addition of this last reagent is carried out slowly over a period of 30 minutes. The mixture is stirred for 60 minutes. Then, a solution of sodium thiosulfate $(5 \% \mathrm{w} / \mathrm{v})(100 \mathrm{ml})$ is added, and extracted with dichloromethane $(3 \times 100 \mathrm{ml})$, the organic layers are dried over sodium sulfate, filtered and concentrated. The residue is purified through column chromatography (silica gel, hexane:AcOEt (40:1)), obtaining $2.59 \mathrm{~g}$ of 2-iodo-4,6-dimethylphenol (52\% yield).

\section{- Sonogashira}

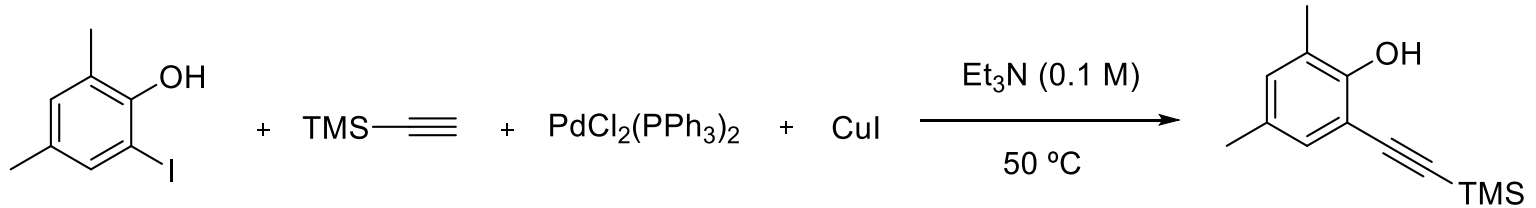

A solution of bis(triphenylphosphine)palladium (II) choride $(0.02$ eq., $0.20 \mathrm{mmol}, 142.2 \mathrm{mg})$ and copper iodide $(0.02$ eq., $0.20 \mathrm{mmol}$, $38.6 \mathrm{mg})$ in trimethylamine $(0.10 \mathrm{M}, 101.30 \mathrm{ml})$ is prepared under argon atmosphere at room temperature. To this solution, 2-iodo4,6-dimethylphenol (1.00 eq., $10.13 \mathrm{mmol}, 2.51 \mathrm{~g}$ ) is added and, after 10 minutes of stirring, trimethylsylilacetylene (1.10 eq., $11.14 \mathrm{mmol}, 1.57 \mathrm{ml}$ ) is added with vigorous shaking and the reaction is allowed to evolve for 6 hours at $50 \stackrel{\circ}{\circ}$. Then, hexane is added and the crude is filtered through celite and purified through column chromatography (silica gel, hexane:AcOEt (40:1)), obtaining $2.12 \mathrm{~g}$ of 4,6-dimethyl-2-[(trimethylsilyl)ethynyl]phenol (96\% yield). 


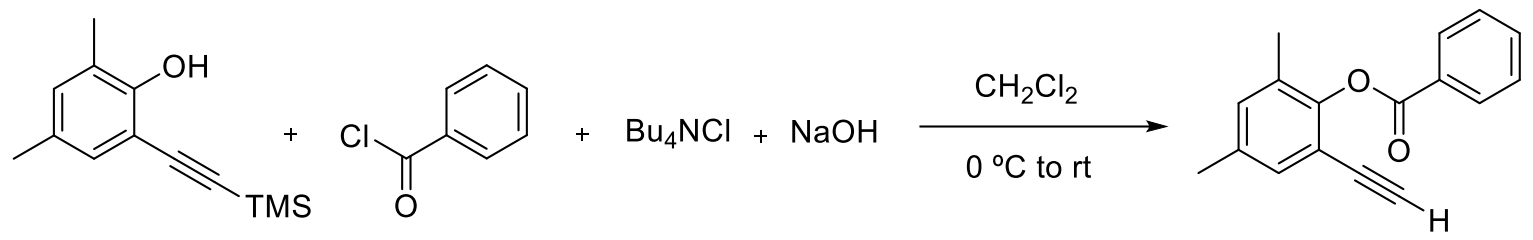

4,6-dimethyl-2-[(trimethylsilyl)ethynyl]phenol (1.00 eq., $1.50 \mathrm{mmol}, 327.6 \mathrm{mg})$ is added to a solution of $\mathrm{NaOH}(10 \%$ in water) and the mixture is cooled to $0 \stackrel{\circ}{\circ}$.. A solution of tetrabutylammonium chloride $(0.10$ eq., $0.15 \mathrm{mmol}, 41.7 \mathrm{mg})$ in anhydrous methylene chloride $(0.30 \mathrm{M}, 0.50 \mathrm{ml})$ is prepared in another flask also at $0 \stackrel{\circ}{\circ} \mathrm{C}$. Then, this solution is added is added to the flask containing the alkyne. Next, a solution benzoyl chloride ( 1.00 eq., $1.50 \mathrm{mmol}, 0.17 \mathrm{ml})$ in ahydrous dichloromethane $(1.00 \mathrm{M}, 1.50 \mathrm{ml})$ is prepared. The later solution is added to the first one and the reaction is stirred vigorously for 5 minutes, keeping the temperature at $0 \stackrel{\circ}{\circ} \mathrm{C}$. ice water $(3 \mathrm{ml})$ is then added, and the resulting mixture is stirred for additional 60 minutes. Next, the mixture is extracted with diethyl ether ( $3 \times 10 \mathrm{ml})$, the organic layers washed with a saturated $\mathrm{NaCl}$ solution $(3 \times 5 \mathrm{ml})$. The mixture is dried over sodium sulfate, filtered and concentrated.The crude of the reaction is purified through column chromatography (silica gel, hexane:AcOEt (20:1)), obtaining $364.1 \mathrm{mg}$ of 2-ethynyl-4,6-dimethylphenyl benzoate (97\% yield).

\section{- lodoalkyne synthesis ${ }^{7}$}<smiles>C#Cc1cc(C)cc(C)c1OC(=O)c1ccccc1</smiles><smiles>Cc1cc(C)c(OC(=O)c2ccccc2)c(C#CI)c1</smiles>

Over a solution of 2-ethynyl-4,6-dimethylphenyl benzoate $(1.00$ eq., $1.30 \mathrm{mmol}, 325.4 \mathrm{mg})$ in acetone $(0.30 \mathrm{M}, 5.50 \mathrm{ml})$ protected from light, $N$-iodosuccinimide $(1.20$ eq., $1.56 \mathrm{mmol}, 350.9 \mathrm{mg})$ and silver nitrate $(0.10$ eq., $0.13 \mathrm{mmol}, 22.1 \mathrm{mg})$ are successively added. The resulting mixture is stirred at room temperature for 3 hours. Next, hexane $(8 \mathrm{ml})$ is added and the mixture is filtered through celite using hexane as eluent. Then, the crude is concentrated and purified by column chromatography (silica gel, hexane:AcOEt (10:1)), obtaining $433.1 \mathrm{mg}$ of de 2-(iodoethynyl)-4,6-dimethylphenyl benzoate (1k) as a yellow solid (89\% yield).

\section{Synthesis of 2-(iodoethynyl)phenyl furan-2-carboxylate (1I)}

\section{- Sonogashira}

(See the General Method) ${ }^{2}$

\section{- Esterificación ${ }^{9}$}<smiles>CC#CC#Cc1ccccc1O</smiles>

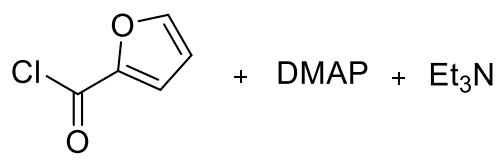<smiles>CCO[N+]([O-])([O-])[O-]</smiles><smiles>CC(C)(C)C</smiles>

Over a solution of 2-[(trimethylsilyl)ethynyl]phenol (1.00 eq., $2.50 \mathrm{mmol}, 475.8 \mathrm{mg})$ in dichloromethane $(0.03 \mathrm{M}, 75.00 \mathrm{ml})$ trimethylamine (4.00 eq., $10.00 \mathrm{mmol}, 1.39 \mathrm{ml})$ and 4-dimethylaminopyridine $(0.05 \mathrm{eq} ., 0.13 \mathrm{mmol}, 15.3 \mathrm{mg})$ are successively added. Next, furan-2-carbonyl chloride is added and the reaction is stirred vigorously for 60 minutes. Then, $\mathrm{NaHCO}_{3}$ is added and the mixture is extracted 3 times with ethyl acetate, and the organic layers washed with $\mathrm{NaHCO}_{3}$ and saturated $\mathrm{NaCl}$, dried over sodium sulfate, filtered and concentrated. The crude of the reaction is purified through column chromatography (silica gel, hexane:AcOEt (10:1)), obtaining $654.5 \mathrm{mg}$ of the product (92\% yield).

\section{- lodoalkyne synthesis ${ }^{4}$}<smiles>CC(C)(C)[N+]([O-])([O-])[O-]</smiles>

Over a solution of 2-[(trimethylsilyl)ethynyl]phenyl furan-2-carboxylate $(1.00$ eq., $2.30 \mathrm{mmol}, 654.1 \mathrm{mg})$ in DMF $(0.20 \mathrm{M}, 11.50 \mathrm{ml})$ protected from light, $N$-iodosuccinimide $(1.50$ eq., $3.45 \mathrm{mmol}, 776.1 \mathrm{mg})$ and silver nitrate $(1.10$ eq., $2.53 \mathrm{mmol}, 429.8 \mathrm{mg})$ are successively added. The resulting mixture is stirred at room temperature for 4 hours and then a saturated $\mathrm{NH}_{4} \mathrm{Cl}$ solution (15 ml) is added, the mixture is filtered through celite using diethyl ether as eluent. The mixture is extracted with diethyl ether $(3 \times 10 \mathrm{ml})$ and the organic layers washed with a saturated $\mathrm{NaCl}$ solution $(5 \times 10 \mathrm{ml})$, dried over sodium sulfate, filtered and concentrated. 
The crude is purified through column chromatography (silica gel, hexane:AcOEt (5:1)), obtaining 396.9 mg of 2-(iodoethynyl)phenyl furan-2-carboxylate (1I) as a white solid (51\% yield).

\section{Synthesis of 2-(iodoethynyl)phenyl thiophene-2-carboxylate (1m)}

\section{- Sonogashira}

$\left(\right.$ See the General Method) ${ }^{2}$

\section{- Esterificación ${ }^{10}$}<smiles>CCN(CC)CCOC(=O)c1ccc(C(=O)Cl)s1</smiles>

Over a solution of thiophene-2-carbonyl chloride (1.00 eq., $3.00 \mathrm{mmol}, 0.32 \mathrm{ml})$ at $0 \stackrel{\circ}{\circ} \mathrm{C}$ in THF $(0.28 \mathrm{M}, 10.71 \mathrm{ml})$ a previously prepared solution of 2-[(trimethylsilyl)ethynyl]phenol $(2.20$ eq., $6.60 \mathrm{mmol}, 1.26 \mathrm{~g})$ in THF $(0.96 \mathrm{M}, 6.88 \mathrm{ml})$ is added dropwise and stirring is maintained for 10 minutes. Next, trimethylamine (2.34 eq., $7.02 \mathrm{mmol}, 10.71 \mathrm{ml}$ ) is added, immediately appearing a precipitate. The mixture is stirred for 14 hours. Then, a solution of $\mathrm{HCl}(5 \mathrm{M})$ is added and the crude is with dichloromethane $(4 \mathrm{x}$ $5 \mathrm{ml}$ ). The organic layers are successively washed with $\mathrm{NaOH}(10 \%)$, diluted $\mathrm{HCl}$ and saturated $\mathrm{NaCl}$, dried over sodium sulfate, filtered and concentrated. The crude of the reaction $(662.9 \mathrm{mg}, 34 \%)$ is used as starting material for the next iodination reaction.

\section{- Preparación del yodoalquino 4}

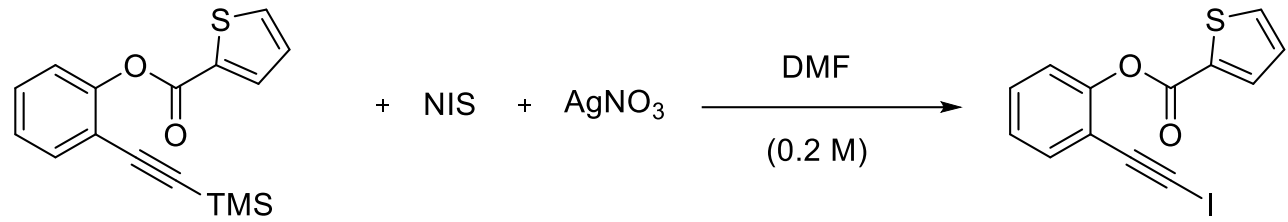

Over a solution of 2-[(trimethylsilyl)ethynyl]phenyl thiophene-2-carboxylate (1.00 eq., $2.21 \mathrm{mmol}, 662.9 \mathrm{mg})$ in DMF (0.20 M, $11.00 \mathrm{ml}$ ) protected from light, $N$-iodosuccinimide $(1.50$ eq., $3.32 \mathrm{mmol}, 745.7 \mathrm{mg})$ and silver nitrate $(1.10 \mathrm{eq} ., 2.43 \mathrm{mmol}, 412.9 \mathrm{mg})$ are successively added. The resulting mixture is stirred at room temperature for 3 hours and then a saturated $\mathrm{NH}_{4} \mathrm{Cl}$ solution $(15 \mathrm{ml})$ is added, the mixture is filtered through celite using diethyl ether as eluent. The mixture is extracted with diethyl ether $(3 \times 10 \mathrm{ml})$ and the organic layers washed with a saturated $\mathrm{NaCl}$ solution $(5 \times 10 \mathrm{ml})$, dried over sodium sulfate, filtered and concentrated. The crude is then purified is purified through column chromatography (silica gel, hexane:AcOEt (10:1)), obtaining $408 \mathrm{mg}$ of 2-(iodoethynyl)phenyl thiophene-2-carboxylate $(1 \mathrm{~m})$ as a yellow solid (52\% yield).

\section{Synthesis of 2-(iodoethynyl)phenyl cinnamate (1n)}

\section{- Sonogashira}

(See the General Method) ${ }^{2}$

\section{- Esterificación ${ }^{11}$}<smiles>CC#Cc1ccccc1O</smiles><smiles>O=C(Cl)/C=C/c1ccccc1</smiles><smiles>CCCCCS(=O)(=O)OCC</smiles><smiles>CC#CC#Cc1ccccc1OC(=O)/C=C/c1ccccc1</smiles>

Over a solution 2-[(trimethylsilyl)ethynyl]phenol (1.00 eq., $3.50 \mathrm{mmol}, 666.1 \mathrm{mg})$ in dichloromethane $(0.50 \mathrm{M}, 7.00 \mathrm{ml})$, cinnamoyl chloride (1.00 eq., $3.50 \mathrm{mmol}, 583.1 \mathrm{mg})$ and triethylamine $(1.40$ eq., $4.90 \mathrm{mmol}, 0.68 \mathrm{ml})$ are successively added. The flask is equipped with a condenser. The mixture is stirred at $70 \stackrel{\circ}{\circ}$ for 1 hour. Then, the crude is washed with water $(3 \times 5 \mathrm{ml})$, and the organic layers are dried over sodium sulfate, filtered and concentrated. The crude of the reaction is purified through column chromatography (silica gel, hexane:AcOEt $(40: 1)$ ), obtaining $935.5 \mathrm{mg}$ of the product ( $84 \%$ yield).

\section{- lodoalkyne synthesis ${ }^{4}$}<smiles>CC(C)(C)C#Cc1ccccc1OC(=O)/C=C/c1ccccc1</smiles> 
Over a solution of 2-[(trimethylsilyl)ethynyl]phenyl cinnamate (1.00 eq., $1.50 \mathrm{mmol}, 480.7 \mathrm{mg})$ in DMF $(0.20 \mathrm{M}, 7.50 \mathrm{ml})$ protected from light, $N$ - iodosuccinimide (1.50 eq., $2.25 \mathrm{mmol}, 506.2 \mathrm{mg}$ ) and silver nitrate (1.10 eq., $1.65 \mathrm{mmol}, 280.3 \mathrm{mg})$ are successively added. The resulting mixture is stirred at room temperature for 3 hours and then, a saturated $\mathrm{NH}_{4} \mathrm{Cl}$ solution (10 ml) is added, the mixture is filtered through celite using diethyl ether as eluent. The mixture is extracted with diethyl ether $(3 \times 10 \mathrm{ml})$ and the organic layers washed with a saturated $\mathrm{NaCl}$ solution $(5 \times 10 \mathrm{ml})$, dried over sodium sulfate, filtered and concentrated. The crude is then purified is purified through column chromatography (silica gel, hexane:AcOEt (80:1)), obtaining 331.9 mg of 2-(iodoethynyl)phenyl cinnamate (1n) as a white solid (59\% yield).

\section{Synthesis of 2-(iodoethynyl)phenyl 3-methylbut-2-enoate (10) ${ }^{\star}$}

\section{- Sonogashira}

$(\text { See the General Method) })^{2}$

\section{- Esterification ${ }^{3}$}<smiles>CC(C)=CC(=O)Oc1ccccc1C#CC#N</smiles>

A solution of $\mathrm{NaH}(1.10$ eq., $4.00 \mathrm{mmol}, 95.1 \mathrm{mg})$ in anhydrous THF $(2.50 \mathrm{M}, 1.60 \mathrm{ml})$ is prepared at $0 \stackrel{\circ}{\circ} \mathrm{C}$. In another flask, under argon atmosphere, a solution of 2-[(trimethylsilyl)ethynyl]phenol (1.00 eq., $3.67 \mathrm{mmol}, 698.2 \mathrm{mg}$ ) in anhydrous THF (0.77 M, $4.80 \mathrm{ml})$ is prepared and then added with a cannula over the $\mathrm{NaH}$ solution during 5 minutes, stirring vigorously. After 10 minutes, a solution of 3-methylbut-2-enoyl chloride $(1.00$ eq., $3.70 \mathrm{mmol}, 0.30 \mathrm{ml})$ in anhydrous THF $(1.55 \mathrm{M}, 2.40 \mathrm{ml})$ is added with a cannula during 5 minutes and the reaction is stirred at room temperature during 4 hours and 30 minutes. Next, water (12.00 ml) and acetic acid (46.20 $\mathrm{M}, 0.08 \mathrm{ml})$ are added and the crude extracted with diethyl ether $(2 \times 10 \mathrm{ml})$. The organic layers are washed with a saturated $\mathrm{NaCl}$ solution $(3 \times 10 \mathrm{ml})$, dried over sodium sulfate, filtered and concentrated. The crude of the reaction is purified through column chromatography (silica gel, hexane:AcOEt (40:1)), obtaining 569.9 mg of 2-[(trimethylsilyl)ethynyl]phenyl 3-methylbut-2-enoate (71\%) as a yellow solid

* For the scaling up, the next amounts were used: $\mathrm{NaH}(1.10 \mathrm{eq} ., 28.90 \mathrm{mmol}, 0.69 \mathrm{~g})$ in anhydrous THF (2.50 M, $11.56 \mathrm{ml})$, 2-[(trimethylsilyl)ethynyl]phenol (1.00 eq., $26.27 \mathrm{mmol}, 5.00 \mathrm{~g})$ in anhydrous THF (0.77 M, $34.12 \mathrm{ml})$, 3-methylbut-2-enoyl chloride (1.10 eq., $28.90 \mathrm{mmol}, 2.30 \mathrm{ml})$ in anhydrous THF (1.55 M, $18.65 \mathrm{ml})$.

\section{- lodoalkyne synthesis ${ }^{4}$}<smiles>CC(C)=CC(=O)Oc1ccccc1C#CC#CC(=O)Oc1ccccc1C#CC(C)(C)C</smiles>

Over a solution of 2-[(trimethylsilyl)ethynyl]phenyl 3-methylbut-2-enoate (1.00 eq., $2.04 \mathrm{mmol}, 556.0 \mathrm{mg})$ in DMF (0.20 M, $10.20 \mathrm{ml})$ protected from light, $N$ - iodosuccinimide (1.50 eq., $3.06 \mathrm{mmol}, 688.4 \mathrm{mg}$ ) and silver nitrate (1.10 eq., $2.24 \mathrm{mmol}, 381.2 \mathrm{mg})$ are successively added. The resulting mixture is stirred at room temperature for 3 hours and then a saturated $\mathrm{NH}_{4} \mathrm{Cl}$ solution (10 ml) is added, the mixture is filtered through celite using diethyl ether as eluent. The mixture is extracted with diethyl ether $(3 \times 10 \mathrm{ml})$ and the organic layers washed with a saturated $\mathrm{NaCl}$ solution $(5 \times 10 \mathrm{ml})$, dried over sodium sulfate, filtered and concentrated. The crude is then purified is purified through column chromatography (silica gel, hexane:AcOEt (80:1)), obtaining $575 \mathrm{mg}$ of 2-(iodoethynyl)phenyl 3-methylbut-2-enoate (10) as a yellow oil (87\% yield).

* For the scaling up of (10) in gram scale, the following amounts were used: 2-[(trimethylsilyl)ethynyl]phenyl 3-methylbut-2-enoate (1.00 eq., $21.16 \mathrm{mmol}, 5.76 \mathrm{~g})$, DMF (0.20 M, $105.80 \mathrm{ml}), \mathrm{N}$-iodosuccinimide (1.50 eq., $31.74 \mathrm{mmol}, 7.14 \mathrm{~g})$ and silver nitrate (1.10 eq., $23.28 \mathrm{mmol}, 3.95 \mathrm{~g})$.

\section{Synthesis of 2-(iodoethynyl)phenyl 2-(6-methoxynaphthalen-2-yl)propanoate (rac-1p)}

\section{- Sonogashira}

(See the General Method) ${ }^{2}$

\section{- Esterificación ${ }^{12}$}<smiles>COc1ccc2cc(C(C)C(=O)O)ccc2c1</smiles> 
Over a solution of 2-(6-methoxynaphthalen-2-yl)propanoic acid (1.00 eq., $2.50 \mathrm{mmol}, 575.7 \mathrm{mg})$ in dichloromethane $(0.76 \mathrm{M}, 3.29 \mathrm{ml})$, $N, N^{\prime}$-Dicyclohexylcarbodiimide (DCC) (1.10 eq., $2.75 \mathrm{mmol}, 567.4 \mathrm{mg}$ ) and $N, N$-dimethylpyridin-4-amine (DMAP) (0.20 eq., $0.50 \mathrm{mmol}, 61.1 \mathrm{mg}$ ) are succesively added. Next, a solution of 2-[(trimethylsilyl)ethynyl]phenol (1.10 eq., $2.75 \mathrm{mmol}, 523.4 \mathrm{mg})$ in dichloromethane $(3.66 \mathrm{M}, 0.75 \mathrm{ml})$ is added and the mixture is stirred for 2 hours y 30 minutes. Then, the mixture is concentrated, ethyl acetate is added $(5 \mathrm{ml})$ and filtered through celite. The crude is washed with a saturated solution of $\mathrm{NaCl}(3 \times 5 \mathrm{ml})$ and the organic layers are dried over sodium sulfate, filtered and concentrated. The crude of the reaction is purified through column chromatography (silica gel, hexane:AcOEt (40:1)), obtaining $904.7 \mathrm{mg}$ of the product ( $82 \%)$.

\section{- lodoalkyne synthesis ${ }^{4}$}<smiles>COc1ccc2cc(C(C)C(=O)Oc3ccccc3C#CC(C)(C)C)ccc2c1</smiles>

Over a solution of 2-[(trimethylsilyl)ethynyl)]phenyl 2-(6-methoxynaphthalen-2-yl)propanoate (1.00 eq., $2.25 \mathrm{mmol}, 904.7 \mathrm{mg})$ ) in DMF $(0.20 \mathrm{M}, 11.24 \mathrm{ml})$ protected from light, $N$ - iodosuccinimide $(1.50 \mathrm{eq} ., 3.37 \mathrm{mmol}, 1.76 \mathrm{~g})$ and silver nitrate $(1.10 \mathrm{eq} ., 2.47 \mathrm{mmol}$, $419.9 \mathrm{mg}$ ) are successively added. The resulting mixture is stirred at room temperature for 2 hours and then a saturated $\mathrm{NH}_{4} \mathrm{Cl}$ solution (12 ml) is added, the mixture is filtered through celite using diethyl ether as eluent. The mixture is extracted with diethyl ether $(3 \times 10 \mathrm{ml})$ and the organic layers washed with a saturated $\mathrm{NaCl}$ solution $(5 \times 10 \mathrm{ml})$, dried over sodium sulfate, filtered and concentrated. The crude is then purified is purified through column chromatography (silica gel, hexane:AcOEt (10:1)), obtaining $809.1 \mathrm{mg}$ of 2-(iodoethynyl)phenyl 2-(6-methoxynaphthalen-2-yl)propanoate (rac-1p) as a yellow oil (79 \% yield). A sample is crystallized for HPLC analysis.

\section{Synthesis of enantioenriched 2-(iodoethynyl)phenyl (S)-2-(6-methoxynaphthalen-2-yl)propanoate (1p)}

\section{- Sonogashira}

(See the General Method $)^{2}$

\section{- Esterificación ${ }^{12}$}<smiles>C#CC#Cc1ccccc1O</smiles><smiles>COc1ccc2cc([C@@H](C)C(=O)O)ccc2c1</smiles><smiles>[2H]C([2H])([2H])[18CH2][13CH3]</smiles><smiles>COc1ccc2cc([C@@H](C)C(=O)Oc3ccccc3C#CC(C)(C)C)ccc2c1</smiles>

According to the above described procedure, using the following amounts: (S)-2-(6-methoxynaphthalen-2-yl)propanoic acid (commercial product specification, purity HPLC: $\geq 97.5 \%$ ) (1.00 eq., $4.77 \mathrm{mmol}, 1.10 \mathrm{~g}$ ), DCC (1.10 eq., $5.25 \mathrm{mmol}, 1.08 \mathrm{~g})$, DMAP (0.20 eq., $0.95 \mathrm{mmol}, 116.5 \mathrm{mg})$ in dichloromethane $(0.76 \mathrm{M}, 6.27 \mathrm{ml})$ y 2-[(trimethylsilyl)ethynyl]phenol $(1.10 \mathrm{eq} ., 5.25 \mathrm{mmol}, 1.00 \mathrm{~g})$ in dichloromethane $(3.66 \mathrm{M}, 1.43 \mathrm{ml})$.

\section{- lodoalkyne synthesis ${ }^{4}$}

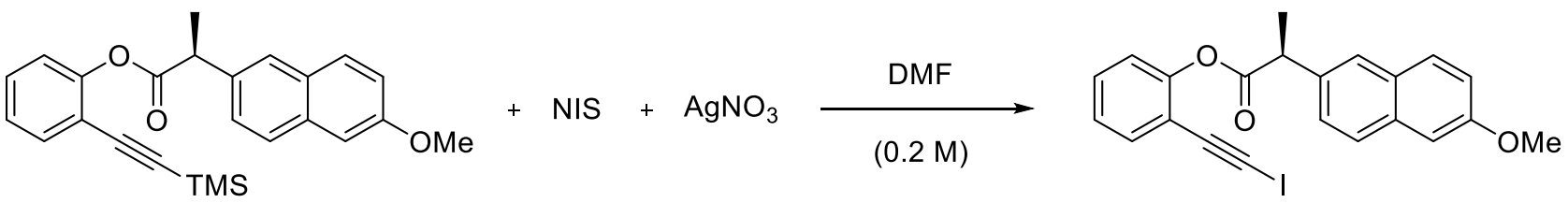

For the scaling up of the starting material (1p) the following amounts were used: 2-[(trimethylsilyl)ethynyl)]phenyl (S)-2-(6methoxynaphthalen-2-yl)propanoate (1.00 eq., $3.99 \mathrm{mmol}, 1.60 \mathrm{~g})$, DMF (0.20 M, $19.95 \mathrm{ml})$, $N$-iodosuccinimide (1.50 eq., $5.98 \mathrm{mmol}$, $1.35 \mathrm{~g})$ and silver nitrate $(1.10 \mathrm{eq} ., 4.39 \mathrm{mmol}, 745.7 \mathrm{mg})$. The final crude was directly crystallized from ethanol/hexane, without column chromatography purification, affording $1,36 \mathrm{~g}$ of brown solid $1 \mathrm{p}$ ( $85 \%$, er: $89: 11)$. The stereochemical outcome is checked by HPLC using CHIRALPAK ${ }^{\circledR}$ AD-H column. 


\subsection{Preparation of final products (2)}<smiles>[R]C(=O)Oc1ccc([X])cc1C#CI</smiles>

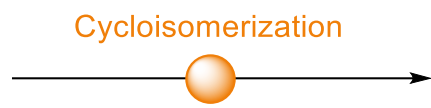<smiles>[R]C(=O)c1oc2ccc([X])cc2c1I</smiles>

The previously described substrates $1 a-1 p$ are used to generate the products $2 a-2 p$ detailed below.

\section{General Method for the preparation of 3-iodobenzo[b]furane derivatives (2)}<smiles>[R]C(=O)Oc1ccc([X])cc1C#CI</smiles>

$[\operatorname{IPrAu}(\mathrm{CH} 3 \mathrm{CN})][\mathrm{SbF} 6]$

$(2.5 \mathrm{~mol} \%)$

$\mathrm{ClCH}_{2} \mathrm{CH}_{2} \mathrm{Cl}(0.1 \mathrm{M})$

$80^{\circ} \mathrm{C}$

The desired iodoalkyne $(1.00$ eq., $0.20 \mathrm{mmol})$ is dissolved in 1,2-dichloroethane $(0.10 \mathrm{M}, 2.00 \mathrm{ml})$ in a carousel flask. Then, [IPrAu( $\left.\left.\mathrm{CH}_{3} \mathrm{CN}\right)\right]\left[\mathrm{SbF}_{6}\right]$ (2.5 mol\%, 0.025 eq., $\left.0.005 \mathrm{mmol}, 4.3 \mathrm{mg}\right)$ is added (unless for compounds $\mathbf{2 k}$ and $\mathbf{2 l}$ that required $5 \mathrm{~mol} \%$ ). Next, the reaction is stirred at $80{ }^{\circ} \mathrm{C}$ and monitorized through TLC. Once the reaction is completed, it is cooled, the solvent removed at low pressure and the crude purified through column chromatography using silica gel as stationary phase (see specific conditions for each substrate).

\section{Synthesis of 1-(3-iodobenzofuran-2-yl)-2-phenylethan-1-one (2a)}<smiles>O=C(Cc1ccccc1)Oc1ccccc1C#CI</smiles>

$$
\begin{gathered}
{\left[\mathrm{IPrAu}\left(\mathrm{CH}_{3} \mathrm{CN}\right)\right]\left[\mathrm{SbF}_{6}\right]} \\
(2.5 \mathrm{~mol} \%) \\
\underset{\mathrm{ClCH}_{2} \mathrm{CH}_{2} \mathrm{Cl}(0.1 \mathrm{M})}{\longrightarrow}
\end{gathered}
$$

$80^{\circ} \mathrm{C}$

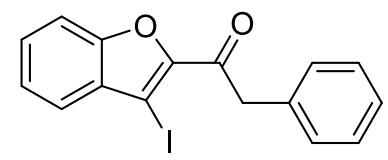

2-(iodoethynyl)phenyl 2-phenyl acetate (1a) $(1.00$ eq., $0.20 \mathrm{mmol}, 72.4 \mathrm{mg})$ is dissolved in anhydrous 1,2 -dichloroethane $(0.10 \mathrm{M}$, $2.00 \mathrm{ml})$ in a carousel flask under argon atmosphere. Then, [IPrAu $\left.\left(\mathrm{CH}_{3} \mathrm{CN}\right)\right]\left[\mathrm{SbF}_{6}\right](2.5 \mathrm{~mol} \%, 0.025 \mathrm{eq} ., 0.005 \mathrm{mmol}, 4.3 \mathrm{mg})$ is added. Next, the reaction is stirred at $80{ }^{\circ} \mathrm{C}$ for 25 minutes. the crude of the reaction is cooled, the solvent removed at low pressure and the crude purified through column chromatography (silica gel, hexane:AcOEt (20:1) obtaining 59.4 mg of 1-(3-iodobenzofuran2-yl)-2-phenylethan-1-one (2a) as a pale yellow solid (82\%).

\section{Synthesis of 1-(3-iodobenzofuran-2-yl)ethan-1-one (2b)}<smiles>CC(=O)Oc1ccccc1C#CI</smiles>

$$
\begin{gathered}
{\left[\mathrm{PrAu}\left(\mathrm{CH}_{3} \mathrm{CN}\right)\right]\left[\mathrm{SbF}_{6}\right]} \\
(2.5 \mathrm{~mol} \%) \\
\hline \mathrm{ClCH}_{2} \mathrm{CH}_{2} \mathrm{Cl}(0.1 \mathrm{M}) \\
80^{\circ} \mathrm{C}
\end{gathered}
$$<smiles>CC(=O)c1oc2ccccc2c1I</smiles>

2-(iodoethynyl)phenyl acetate (1b) (1.00 eq., $0.20 \mathrm{mmol}, 57.4 \mathrm{mg})$ is dissolved in anhydrous 1,2-dichloroethane $(0.10 \mathrm{M}, 2.00 \mathrm{ml})$ in a carousel flask under argon atmosphere. Then, [IPrAu $\left.\left(\mathrm{CH}_{3} \mathrm{CN}\right)\right]\left[\mathrm{SbF}_{6}\right](2.5 \mathrm{~mol} \%, 0.025$ eq., $0.005 \mathrm{mmol}, 4.3 \mathrm{mg})$ is added. Next, the reaction is stirred at $80^{\circ} \mathrm{C}$ for 25 minutes. The crude of the reaction is cooled, the solvent removed at low pressure and the crude purified through column chromatography (silica gel, hexane:AcOEt (20:1) obtaining $44.5 \mathrm{mg}$ of 1-(3-iodobenzofuran-2-yl)ethan-1-one (2b) as a pale yellow solid (78\%).

\section{Synthesis of 1-(3-iodobenzofuran-2-yl)-3-methylbutan-1-one (2c)}<smiles>CC(C)CC(=O)Oc1ccccc1C#CI</smiles>

$$
\begin{gathered}
{\left[\mathrm{IPrAu}\left(\mathrm{CH}_{3} \mathrm{CN}\right)\right]\left[\mathrm{SbF}_{6}\right]} \\
(2.5 \mathrm{~mol} \%) \\
\hline \mathrm{ClCH}_{2} \mathrm{CH}_{2} \mathrm{Cl}(0.1 \mathrm{M}) \\
80^{\circ} \mathrm{C}
\end{gathered}
$$<smiles>CC(C)CC(=O)c1oc2ccccc2c1I</smiles>

2-(iodoethynyl)phenyl 3-methylbutanoate (1c) $(1.00$ eq., $0.20 \mathrm{mmol}, 65.6 \mathrm{mg})$ is dissolved in anhydrous 1,2 -dichloroethane $(0.10 \mathrm{M}$, $2.00 \mathrm{ml})$ in a carousel flask under argon atmosphere. Then, [IPrAu( $\left.\left.\mathrm{CH}_{3} \mathrm{CN}\right)\right]\left[\mathrm{SbF}_{6}\right](2.5 \mathrm{~mol} \%, 0.025$ eq., $0.005 \mathrm{mmol}, 4.3 \mathrm{mg})$ is added. Next, the reaction is stirred at $80{ }^{\circ} \mathrm{C}$ for 50 minutes. The crude of the reaction is cooled, the solvent removed at low pressure and the crude purified through column chromatography (silica gel, hexane:AcOEt (40:1). The compound is recrystallized from dichloromethane y pentane, affording $50.2 \mathrm{mg}$ of 1-(3-iodobenzofuran-2-yl)-3-methylbutan-1-one (2c) as yellow needles (77 \%). 
<smiles>O=C(CCc1ccccc1)Oc1ccccc1C#CI</smiles>

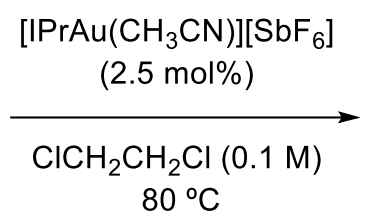<smiles>O=C(CCc1ccccc1)c1oc2ccccc2c1I</smiles>

2-(iodoethynyl)phenyl 3-phenylpropanoate (1d) (1.00 eq., $0.20 \mathrm{mmol}, 75.2 \mathrm{mg}$ ) is dissolved in anhydrous 1,2-dichloroethane (0.10 M, $2.00 \mathrm{ml})$ in a carousel flask under argon atmosphere. Then, [IPrAu $\left.\left(\mathrm{CH}_{3} \mathrm{CN}\right)\right]\left[\mathrm{SbF}_{6}\right](2.5 \mathrm{~mol} \%, 0.025$ eq., $0.005 \mathrm{mmol}, 4.3 \mathrm{mg})$ is added. Next, the reaction is stirred at $80{ }^{\circ} \mathrm{C}$ for 25 minutes. The crude of the reaction is cooled, the solvent removed at low pressure and the crude purified through column chromatography (silica gel, hexane:AcOEt (40:1) obtaining 60.1 mg of 1-(3-iodobenzofuran2-yl)-3-phenylpropan-1-one (2d) as a yellow solid (80\%).

\section{Synthesis of (3-iodobenzofuran-2-yl)(phenyl)methanone (2e)}<smiles>O=C(Oc1ccccc1C#CI)c1ccccc1</smiles>

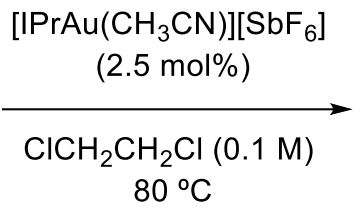<smiles>O=C(c1ccccc1)c1oc2ccccc2c1I</smiles>

2-(iodoethynyl)phenyl benzoate (1e) $(1.00$ eq., $0.20 \mathrm{mmol}, 69.6 \mathrm{mg})$ is dissolved in anhydrous 1,2-dichloroethane $(0.10 \mathrm{M}, 2.00 \mathrm{ml})$ in a carousel flask under argon atmosphere. Then, [IPrAu $\left.\left(\mathrm{CH}_{3} \mathrm{CN}\right)\right]\left[\mathrm{SbF}_{6}\right](2.5 \mathrm{~mol} \%, 0.025$ eq., $0.005 \mathrm{mmol}, 4.3 \mathrm{mg})$ is added. Next, the reaction is stirred at $80{ }^{\circ} \mathrm{C}$ for 4 hours. The crude of the reaction is cooled, the solvent removed at low pressure and the crude purified through column chromatography (silica gel, hexane:AcOEt (20:1) obtaining 53.1 mg of (3-iodobenzofuran$2-y l)($ phenyl)methanone (2e) as a yellow oil $(76 \%)$.

\section{Synthesis of (3-iodobenzofuran-2-yl)(4-methoxyphenyl)methanone (2f)}<smiles>COc1ccc(C(=O)Oc2ccccc2C#CI)cc1</smiles>

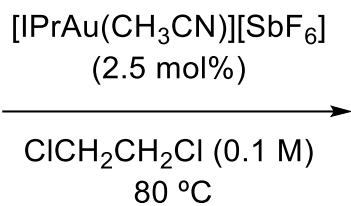<smiles>COc1ccc(C(=O)c2oc3ccccc3c2I)cc1</smiles>

2-(iodoethynyl)phenyl 4-methoxybenzoate (1f) $(1.00$ eq., $0.20 \mathrm{mmol}, 75.6 \mathrm{mg})$ is dissolved in anhydrous 1,2 -dichloroethane (0.10 $\mathrm{M}$, $2.00 \mathrm{ml})$ in a carousel flask under argon atmosphere. Then, [IPrAu $\left.\left(\mathrm{CH}_{3} \mathrm{CN}\right)\right][\mathrm{SbF}$ ] $(2.5 \mathrm{~mol} \%, 0.025 \mathrm{eq} ., 0.005 \mathrm{mmol}, 4.3 \mathrm{mg})$ is added. Next, the reaction is stirred at $80{ }^{\circ} \mathrm{C}$ for 20 minutes. The crude of the reaction is cooled, the solvent removed at low pressure and the crude purified through column chromatography (silica gel, hexane:AcOEt (20:1) obtaining $30.2 \mathrm{mg}$ of (3-iodobenzofuran-2-yl) (4-methoxyphenyl)methanone (2f) as a pale yellow solid (43\%).

\section{Synthesis of (3-iodobenzofuran-2-yl)(4-bromophenyl)methanone (2g)}<smiles>O=C(Oc1ccccc1C#CI)c1ccc(Br)cc1</smiles>

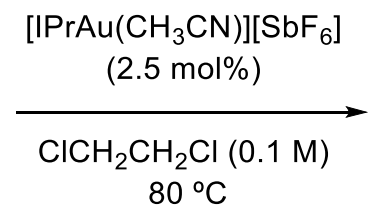<smiles>O=C(c1ccc(Br)cc1)c1oc2ccccc2c1I</smiles>

2-(iodoethynyl)phenyl 4-bromobenzoate (1 $\mathbf{g})(1.00$ eq., $0.20 \mathrm{mmol}, 85.4 \mathrm{mg})$ is dissolved in anhydrous 1,2-dichloroethane $(0.10 \mathrm{M}$, $2.00 \mathrm{ml})$ in a carousel flask under argon atmosphere. Then, [IPrAu $\left.\left(\mathrm{CH}_{3} \mathrm{CN}\right)\right][\mathrm{SbF} 6](2.5 \mathrm{~mol} \%, 0.025$ eq., $0.005 \mathrm{mmol}, 4.3 \mathrm{mg})$ is added. Next, the reaction is stirred at $80^{\circ} \mathrm{C}$ for 60 minutes. The crude of the reaction is cooled, the solvent removed at low pressure and the crude purified through column chromatography (silica gel, hexane:AcOEt (20:1) obtaining 56.1 mg of (3-iodobenzofuran2-yl)(4-bromophenyl)methanone $\mathbf{( 2 g}$ ) as a yellow solid (66\%). 
<smiles>O=C(Oc1ccc(Cl)cc1C#CI)c1ccccc1</smiles>

$$
\begin{gathered}
{\left[\mathrm{IPrAu}\left(\mathrm{CH}_{3} \mathrm{CN}\right)\right]\left[\mathrm{SbF}_{6}\right]} \\
(2.5 \mathrm{~mol} \%) \\
\hline \mathrm{CICH}_{2} \mathrm{CH}_{2} \mathrm{Cl}(0.1 \mathrm{M}) \\
80^{\circ} \mathrm{C}
\end{gathered}
$$<smiles>O=C(c1ccccc1)c1oc2ccc(Cl)cc2c1I</smiles>

4-chloro-2-(iodoethynyl)phenyl benzoate (1h) $(1.00$ eq., $0.20 \mathrm{mmol}, 76.5 \mathrm{mg})$ ) is dissolved in anhydrous 1,2 -dichloroethane $(0.10 \mathrm{M}$, $2.00 \mathrm{ml})$ in a carousel flask under argon atmosphere. Then, [IPrAu $\left.\left(\mathrm{CH}_{3} \mathrm{CN}\right)\right]\left[\mathrm{SbF}_{6}\right](2.5 \mathrm{~mol} \%, 0.025$ eq., $0.005 \mathrm{mmol}, 4.3 \mathrm{mg})$ is added. Next, the reaction is stirred at $80{ }^{\circ} \mathrm{C}$ for 90 minutes. The crude of the reaction is cooled, the solvent removed at low pressure and the crude purified through column chromatography (silica gel, hexane:AcOEt (20:1) obtaining 51.9 mg of (5-chloro3-iodobenzofuran-2-yl)(phenyl)methanone (2h) as a yellow solid (68 \%).

\section{Synthesis of ethyl 2-benzoyl-3-iodobenzofuran-5-carboxylate (2i)}<smiles>CCOC(=O)c1ccc(OC(=O)c2ccccc2)c(C#CI)c1</smiles>

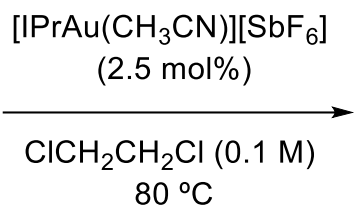<smiles>CCOC(=O)c1ccc2oc(C(=O)c3ccccc3)c(I)c2c1</smiles>

ethyl 4-(benzoyloxy)-3-(iodoethynyl)benzoate (1i) (1.00 eq., $0.20 \mathrm{mmol}, 84.0 \mathrm{mg}$ ) is dissolved in anhydrous 1,2-dichloroethane $(0.10 \mathrm{M}, 2.00 \mathrm{ml})$ in a carousel flask under argon atmosphere. Then, [IPrAu $\left.\left(\mathrm{CH}_{3} \mathrm{CN}\right)\right][\mathrm{SbF} 6](2.5 \mathrm{~mol} \%, 0.025 \mathrm{eq} ., 0.005 \mathrm{mmol}$ $4.3 \mathrm{mg}$ ) is added. Next, the reaction is stirred at $80^{\circ} \mathrm{C}$ for 24 hours. The crude of the reaction is cooled, the solvent removed at low pressure and the crude purified through column chromatography (silica gel, Hexane:AcOEt (40:1) obtaining 60.6 mg of ethyl 2-benzoyl-3-iodobenzofuran-5-carboxylate (2i) as a yellow solid (72\%).

Synthesis of (3-iodo-5-methylbenzofuran-2-yl)(phenyl)methanone (2j)<smiles>Cc1ccc(OC(=O)c2ccccc2)c(C#CI)c1</smiles>

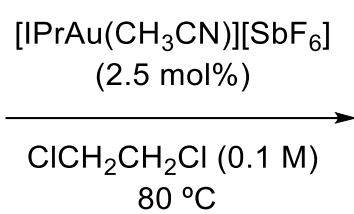<smiles>Cc1ccc2oc(C(=O)c3ccccc3)c(I)c2c1</smiles>

2-(iodoethynyl)-4-methylphenyl benzoate (1j) (1.00 eq., $0.20 \mathrm{mmol}, 72.4 \mathrm{~g})$ is dissolved in anhydrous 1,2-dichloroethane (0.10 $\mathrm{M}$, $2.00 \mathrm{ml})$ in a carousel flask under argon atmosphere. Then, [IPrAu $\left.\left(\mathrm{CH}_{3} \mathrm{CN}\right)\right]\left[\mathrm{SbF}_{6}\right](2.5 \mathrm{~mol} \%, 0.025$ eq., $0.005 \mathrm{mmol}, 4.3 \mathrm{mg})$ is added. Next, the reaction is stirred at $80{ }^{\circ} \mathrm{C}$ for 4 hours. The crude of the reaction is cooled, the solvent removed at low pressure and the crude purified through column chromatography (silica gel, hexane:AcOEt (10:1) obtaining 54.9 mg (3-iodo-5-methylbenzofuran$2-\mathrm{yl})$ (phenyl)methanone (2j) as a pale yellow solid (76\%).

\section{Synthesis of (3-iodo-5,7-dimethylbenzofuran-2-yl)(phenyl)methanone (2k)}<smiles>Cc1cc(C)c(OC(=O)c2ccccc2)c(C#CI)c1</smiles>

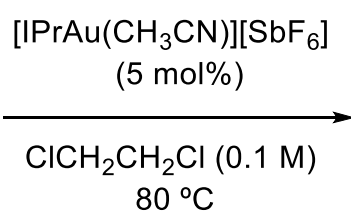<smiles>Cc1cc(C)c2oc(C(=O)c3ccccc3)c(I)c2c1</smiles>

2-(iodoethynyl)-4,6-dimethylphenyl benzoate (1k) (1.00 eq., $0.20 \mathrm{mmol}, 75.2 \mathrm{mg}$ ) is dissolved in anhydrous 1,2-dichloroethane $(0.10 \mathrm{M}, 2.00 \mathrm{ml})$ in a carousel flask under argon atmosphere. Then, [IPrAu$\left.\left(\mathrm{CH}_{3} \mathrm{CN}\right)\right]\left[\mathrm{SbF}_{6}\right](5 \mathrm{~mol} \%, 0.10$ eq., $0.010 \mathrm{mmol}, 8.6 \mathrm{mg})$ is added. Next, the reaction is stirred at $80^{\circ} \mathrm{C}$ for 1 hour. The crude of the reaction is cooled, the solvent removed at low pressure and the crude purified through column chromatography (silica gel, hexane:AcOEt (40:1) obtaining 33.9 mg of (3-iodo5,7-dimethylbenzofuran-2-yl)(phenyl)methanone (2k) as yellow needles (85\%). 
<smiles>O=C(Oc1ccccc1C#CI)c1ccco1</smiles>

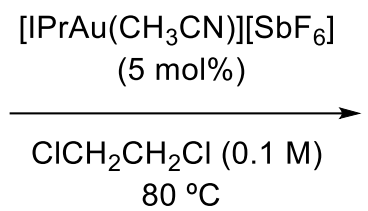<smiles>O=C(c1ccco1)c1oc2ccccc2c1I</smiles>

2-(iodoethynyl)phenyl furan-2-carboxylate (1I) $(1.00$ eq., $0.20 \mathrm{mmol}, 67.6 \mathrm{mg})$ is dissolved in anhydrous 1,2 -dichloroethane $(0.10 \mathrm{M}$, $2.00 \mathrm{ml})$ in a carousel flask under argon atmosphere. Then, [IPrAu$\left.\left(\mathrm{CH}_{3} \mathrm{CN}\right)\right]\left[\mathrm{SbF}_{6}\right](5 \mathrm{~mol} \%, 0.10$ eq., $0.010 \mathrm{mmol}, 8.6 \mathrm{mg})$ is added. Next, the reaction is stirred at $80{ }^{\circ} \mathrm{C}$ for 3 hours. The crude of the reaction is cooled, the solvent removed at low pressure and the crude purified through column chromatography (silica gel, hexane:AcOEt (20:1) obtaining $26.3 \mathrm{mg}$ of furan-2-yl(3-iodobenzofuran$2-\mathrm{yl})$ methanone (2I) as a yellow oil $(78 \%)$.

\section{Synthesis of (3-iodobenzofuran-2-yl)(thiophen-2-yl)methanone (2m)}<smiles>O=C(Oc1ccccc1C#CI)c1cccs1</smiles>

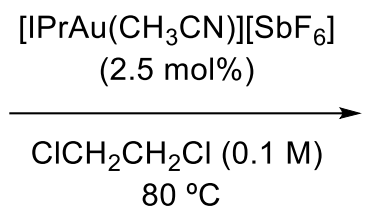<smiles>O=C(c1cccs1)c1oc2ccccc2c1I</smiles>

2-(iodoethynyl)phenyl thiophene-2-carboxylate (1m) $(1.00$ eq., $0.20 \mathrm{mmol}, 70.8 \mathrm{mg})$ is dissolved in anhydrous 1,2 -dichloroethane $(0.10 \mathrm{M}, 2.00 \mathrm{ml})$ in a carousel flask under argon atmosphere. Then, [IPrAu $\left.\left(\mathrm{CH}_{3} \mathrm{CN}\right)\right]\left[\mathrm{SbF}_{6}\right](2.5 \mathrm{~mol} \%, 0.025 \mathrm{eq} ., 0.005 \mathrm{mmol}$, $4.3 \mathrm{mg}$ ) is added. Next, the reaction is stirred at $80^{\circ} \mathrm{C}$ for 75 minutes. The crude of the reaction is cooled, the solvent removed at low pressure and the crude purified through column chromatography (silica gel, hexane:AcOEt (20:1) obtaining $53.0 \mathrm{mg}$ of (3iodobenzofuran-2-yl)(thiophen-2-yl)methanone (2m), as a yellow solid (75\%).

\section{Synthesis of (E)-1-(3-iodobenzofuran-2-yl)-3-phenylprop-2-en-1-one (2n)}<smiles>O=C(/C=C/c1ccccc1)Oc1ccccc1C#CI</smiles>

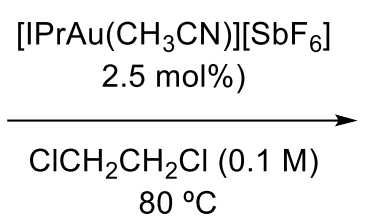<smiles>O=C(/C=C/c1ccccc1)c1oc2ccccc2c1I</smiles>

2-(iodoethynyl)phenyl cinnamate (1n) $(1.00$ eq., $0.20 \mathrm{mmol}, 74.8 \mathrm{mg})$ is dissolved in anhydrous 1,2-dichloroethane $(0.10 \mathrm{M}, 2.00 \mathrm{ml})$ in a carousel flask under argon atmosphere. Then, [IPrAu( $\left.\left.\mathrm{CH}_{3} \mathrm{CN}\right)\right]\left[\mathrm{SbF}_{6}\right](2.5 \mathrm{~mol} \%, 0.025$ eq., $0.005 \mathrm{mmol}, 4.3 \mathrm{mg})$ is added. Next, the reaction is stirred at $80{ }^{\circ} \mathrm{C}$ for 20 minutes. The crude of the reaction is cooled, the solvent removed at low pressure and the crude purified through column chromatography (silica gel, hexane:AcOEt (40:1) obtaining $48.4 \mathrm{mg}$ of (E)-1-(3-iodobenzofuran-2-yl)3-phenylprop-2-en-1-one (2n) as an orange solid (65\%).

\section{Synthesis of 1-(3-iodobenzofuran-2-yl)-3-methylbut-2-en-1-one (20)*}<smiles>CC(C)=CC(=O)Oc1ccccc1C#CI</smiles>

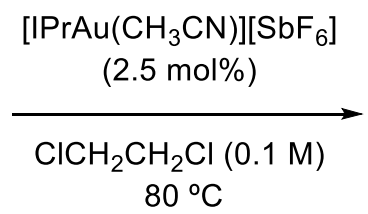<smiles>CC(C)=CC(=O)c1oc2ccccc2c1I</smiles>

2-(iodoethynyl)phenyl 3-methylbut-2-enoate (10) (1.00 eq., $0.20 \mathrm{mmol}, 65.2 \mathrm{mg}$ ) is dissolved in anhydrous 1,2-dichloroethane $(0.10 \mathrm{M}, 2.00 \mathrm{ml})$ in a carousel flask under argon atmosphere. Then, [IPrAu $\left.\left(\mathrm{CH}_{3} \mathrm{CN}\right)\right]\left[\mathrm{SbF}_{6}\right](2.5 \mathrm{~mol} \%, 0.025 \mathrm{eq} ., 0.005 \mathrm{mmol}$, $4.3 \mathrm{mg}$ ) is added. Next, the reaction is stirred at $80^{\circ} \mathrm{C}$ for 30 minutes. The crude of the reaction is cooled, the solvent removed at low pressure and the crude purified through column chromatography (silica gel, hexane:AcOEt (40:1) obtaining 53.2 mg of 1-(3iodobenzofuran-2-yl)-3-methylbut-2-en-1-one (20) as a yellow solid (81\%).

*This reaction was scaled up using the following amounts: 2-(iodoethynyl)phenyl 3-methylbut-2-enoate (10) (1.00 eq., $5.71 \mathrm{mmol}$, $1.86 \mathrm{~g}), 1,2$-dichloroethane $(0.10 \mathrm{M}, 57.00 \mathrm{ml})$ and $\left[\mathrm{IPrAu}\left(\mathrm{CH}_{3} \mathrm{CN}\right)\right]\left[\mathrm{SbF}_{6}\right](2.5 \mathrm{~mol} \%, 0.025 \mathrm{eq}$., $0.14 \mathrm{mmol}, 123.1 \mathrm{mg})$ for $20 \mathrm{minutes}$ a $80 \stackrel{\circ}{\circ}$, obtaining $1.46 \mathrm{~g}$ of 1-(3-iodobenzofuran-2-yl)-3-methylbut-2-en-1-one (20) (78\%). 
<smiles>COc1ccc2cc(C(C)C(=O)Oc3ccccc3C#CI)ccc2c1</smiles>

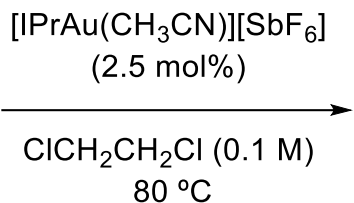<smiles>COc1ccc2cc([C@@H](C)C(=O)c3oc4ccccc4c3I)ccc2c1</smiles>

The racemic product (rac-2p), which is required for HPLC studies concerning the enantioenriched formed of $2 \mathbf{p}$, is prepared as follows: 2-(iodoethynyl)phenyl 2-(6-methoxynaphthalen-2-yl)propanoate (rac-1p) (1.00 eq., $0.20 \mathrm{mmol}, 91.3 \mathrm{mg}$ ) is dissolved in anhydrous 1,2-dichloroethane $(0.10 \mathrm{M}, 2.00 \mathrm{ml})$ in a carousel flask under argon atmosphere. Then, [ $\left.\mathrm{IPrAu}\left(\mathrm{CH}_{3} \mathrm{CN}\right)\right]\left[\mathrm{SbF}_{6}\right](2.5 \mathrm{~mol} \%$, 0.025 eq., $0.005 \mathrm{mmol}, 4.3 \mathrm{mg}$ ) is added. Next, the reaction is stirred at $80^{\circ} \mathrm{C}$ for 75 minutes. The crude of the reaction is cooled, the solvent removed at low pressure and the crude purified through column chromatography (silica gel, hexane:AcOEt (10:1) obtaining $60.9 \mathrm{mg}$ of 1-(3-iodobenzofuran-2-yl)-2-(6-methoxynaphthalen-2-yl)propan-1-one (rac-2p) as a yellow oil (67\%).

\section{Synthesis of enantioenriched (S)-1-(3-iodobenzofuran-2-yl)-2-(6-methoxynaphthalen-2-yl)propan-1-one (2p)}<smiles>COc1ccc2cc([C@@H](C)C(=O)Oc3ccccc3C#CI)ccc2c1</smiles>

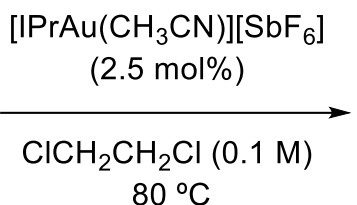<smiles>COc1ccc2cc([C@@H](C)C(=O)c3oc4ccccc4c3I)ccc2c1</smiles>

The preparation of optically active $\mathbf{2 p}$, is prepared as above described using the following amounts of reagents: 2-(iodoethynyl)phenyl 2-(6-methoxynaphthalen-2-yl)propanoate (1p) (1.00 eq., $2.71 \mathrm{mmol}, 1.23 \mathrm{~g})$, 1,2-dichloroetane (0.10 M, $27.1 \mathrm{ml})$ and [IPrAu$\left.\left(\mathrm{CH}_{3} \mathrm{CN}\right)\right]\left[\mathrm{SbF}_{6}\right](2.5 \mathrm{~mol} \%, 0.025$ eq., $0.07 \mathrm{mmol}, 58.4 \mathrm{mg})$ for 75 minutes a $80 \stackrel{\circ}{ } \mathrm{C} .689 \mathrm{mg}$ of the enantioenriched $(2 \mathrm{p})$ is isolated (56\% yield, er: $87: 13)$. 


\section{Characterization data}

\subsection{Characterization data for starting materials (1)}

\section{2-(iodoethynyl)phenyl 2-phenylacetate (1a)}<smiles>O=C(Cc1ccccc1)Oc1ccccc1C#CI</smiles>

Chemical Formula: $\mathrm{C}_{16} \mathrm{H}_{11} \mathrm{IO}_{2}$

Physical State: Yellow solid, m.p.: $55-56 \stackrel{\circ}{\mathrm{C}}$

Yield: $90 \%$

HRMS calcd. for $\mathrm{C}_{16} \mathrm{H}_{11} \mathrm{INaO}_{2}(\mathrm{M}+\mathrm{Na}): 384.9696$

HRMS (ESI) found: 384.9695

${ }^{1} \mathrm{H}$ NMR $\left(300 \mathrm{MHz}, \mathrm{CD}_{2} \mathrm{Cl}_{2}\right): \delta(\mathrm{ppm}) 7.52(\mathrm{dd}, J=7.6,1.6 \mathrm{~Hz}, 1 \mathrm{H}), 7.46-7.35(\mathrm{~m}, 6 \mathrm{H}), 7.26(\mathrm{td}, J=7.6,1.3 \mathrm{~Hz}, 1 \mathrm{H}), 7.12(\mathrm{dd}$, $J=8.1,1.0 \mathrm{~Hz}, 1 \mathrm{H}), 3.97(\mathrm{~s}, 2 \mathrm{H})$.

${ }^{13} \mathrm{C}$ NMR (100 MHz, $\left.\mathbf{C D}_{2} \mathrm{Cl}_{2}\right): \delta(\mathrm{ppm}) 169.5(\mathrm{C}), 152.7(\mathrm{C}), 133.7(\mathrm{CH}), 133.4(\mathrm{C}), 130.0(\mathrm{CH}), 129.6(2 \mathrm{CH}), 128.7(2 \mathrm{CH})$, $127.3(\mathrm{CH}), 125.9(\mathrm{CH}), 122.3(\mathrm{CH}), 117.3(\mathrm{C}), 88.9(\mathrm{C}), 40.9\left(\mathrm{CH}_{2}\right), 11.6(\mathrm{C})$.

\section{2-(iodoethynyl)phenyl acetate (1b)}<smiles>CC(=O)Oc1ccccc1C#CI</smiles>

Chemical Formula: $\mathrm{C}_{10} \mathrm{H}_{7} \mathrm{IO}_{2}$

Physical State: Pale yellow oil

Yield: $82 \%$

HRMS calcd. for $\mathrm{C}_{10} \mathrm{H}_{7} \mathrm{INaO}_{2}(\mathrm{M}+\mathrm{Na}): 308.9383$

HRMS (ESI) found: 308.9386

${ }^{1} \mathrm{H}$ NMR $\left(300 \mathrm{MHz}, \mathrm{CD}_{2} \mathrm{Cl}_{2}\right): \delta(\mathrm{ppm}) 7.56(\mathrm{dd}, J=7.7,1.7 \mathrm{~Hz}, 1 \mathrm{H}), 7.43(\mathrm{td}, J=7.7,1.7 \mathrm{~Hz}, 1 \mathrm{H}), 7.27(\mathrm{t}, J=7.6 \mathrm{~Hz}, 1 \mathrm{H}), 7.17(\mathrm{~d}$, $J=8.1 \mathrm{~Hz}, 1 \mathrm{H}), 2.37(\mathrm{~s}, 3 \mathrm{H})$.

${ }^{13} \mathrm{C}$ NMR (75 MHz, $\left.\mathrm{CD}_{2} \mathrm{Cl}_{2}\right): \delta(\mathrm{ppm}) 168.9(\mathrm{C}), 152.9(\mathrm{C}), 133.7(\mathrm{CH}), 130.2(\mathrm{CH}), 126.0(\mathrm{CH}), 122.5(\mathrm{CH}), 117.5(\mathrm{C}), 89.2(\mathrm{C})$, $20.8\left(\mathrm{CH}_{3}\right), 12.5(\mathrm{C})$.

\section{2-(iodoethynyl)phenyl 3-methylbutanoate (1c)}<smiles>CC(C)CC(=O)Oc1ccccc1C#CI</smiles>

Chemical Formula: $\mathrm{C}_{13} \mathrm{H}_{13} \mathrm{IO}_{2}$

Physical State: Yellow oil

Yield: $56 \%$

HRMS calcd. for $\mathrm{C}_{13} \mathrm{H}_{13} \mathrm{INaO}_{2}(\mathrm{M}+\mathrm{Na}): 350.9852$

HRMS (ESI) found: 350.9852

${ }^{1} \mathrm{H}$ NMR $\left(400 \mathrm{MHz}, \mathrm{CD}_{2} \mathrm{Cl}_{2}\right): \delta(\mathrm{ppm}) 7.52(\mathrm{dd}, J=7.6,1.8 \mathrm{~Hz}, 1 \mathrm{H}), 7.40(\mathrm{td}, J=7.8,1.8 \mathrm{~Hz}, 1 \mathrm{H}), 7.24(\mathrm{td}, J=7.6,1.3 \mathrm{~Hz}, 1 \mathrm{H})$ $7.11(\mathrm{dd}, J=8.0,1.3 \mathrm{~Hz}, 1 \mathrm{H}), 2.51(\mathrm{~d}, J=6.9 \mathrm{~Hz}, 1 \mathrm{H}), 2.29($ non, $J=6.7 \mathrm{~Hz}, 1 \mathrm{H}), 1.13(\mathrm{~d}, J=6.7 \mathrm{~Hz}, 6 \mathrm{H})$.

${ }^{13} \mathrm{C}$ NMR (100 MHz, $\left.\mathrm{CD}_{2} \mathrm{Cl}_{2}\right)$ : $\delta(\mathrm{ppm}) 170.9(\mathrm{C}), 152.7(\mathrm{C}), 133.7(\mathrm{CH}), 130.0(\mathrm{CH}), 125.8(\mathrm{CH}), 122.5(\mathrm{CH}), 117.5(\mathrm{C}), 89.1(\mathrm{C})$ $43.08\left(\mathrm{CH}_{2}\right), 25.8(\mathrm{CH}), 22.4\left(2 \mathrm{CH}_{3}\right), 11.7(\mathrm{C})$. 
<smiles>O=C(CCc1ccccc1)Oc1ccccc1C#CI</smiles>

Chemical Formula: $\mathrm{C}_{17} \mathrm{H}_{13} \mathrm{IO}_{2}$

Physical State: Yellow oil

Yield: $86 \%$

HRMS calcd. for $\mathrm{C}_{17} \mathrm{H}_{13} \mid \mathrm{NaO}_{2}(\mathrm{M}+\mathrm{Na}): 398.9852$

HRMS (ESI) found: 398.9849

${ }^{1} \mathrm{H}$ NMR $\left(300 \mathrm{MHz}, \mathrm{CD}_{2} \mathrm{Cl}_{2}\right): \delta(\mathrm{ppm}) 7.53(\mathrm{dd}, J=7.6,1.5 \mathrm{~Hz}, 1 \mathrm{H}), 7.44-7.24(\mathrm{~m}, 7 \mathrm{H}), 7.10(\mathrm{~d}, J=7.8 \mathrm{~Hz}, 1 \mathrm{H}), 3.15(\mathrm{AA}$ ', 2H), 2.96 (BB', 2H).

${ }^{13} \mathrm{C}$ NMR $\left(75 \mathrm{MHz}, \mathrm{CD}_{2} \mathrm{Cl}_{2}\right): \delta(\mathrm{ppm}) 170.8(\mathrm{C}), 152.7(\mathrm{C}), 140.4(\mathrm{C}), 133.6(\mathrm{C}), 130.0(\mathrm{CH}), 128.6(2 \mathrm{CH}), 128.3(2 \mathrm{CH}), 126.4(\mathrm{CH})$, $125.8(\mathrm{CH}), 122.4(\mathrm{CH}), 117.3(\mathrm{C}), 89.0(\mathrm{C}), 35.8\left(\mathrm{CH}_{2}\right), 31.0\left(\mathrm{CH}_{2}\right), 11.6(\mathrm{C})$.

\section{2-(iodoethynyl)phenyl benzoate (1e)}<smiles>O=C(Oc1ccccc1C#CI)c1ccccc1</smiles>

Chemical Formula: $\mathrm{C}_{15} \mathrm{H}_{9} \mathrm{IO}_{2}$

Physical State: Brown oil

Yield: $87 \%$

HRMS calcd. for $\mathrm{C}_{15} \mathrm{H}_{9} \mathrm{NaO}_{2}(\mathrm{M}+\mathrm{Na}): 370.9539$

HRMS (ESI) found: 370.9542

${ }^{1} \mathrm{H}$ NMR $\left(300 \mathrm{MHz}, \mathbf{C D}_{2} \mathrm{Cl}_{2}\right)$ : $\delta(\mathrm{ppm}) 8.26-8.24(\mathrm{~m}, 2 \mathrm{H}), 7.77-7.68(\mathrm{~m}, 1 \mathrm{H}), 7.62-7.56(\mathrm{~m}, 3 \mathrm{H}), 7.50-7.44(\mathrm{~m}, 1 \mathrm{H}), 7.33-7.28$ $(\mathrm{m}, 2 \mathrm{H})$.

${ }^{13} \mathrm{C}$ NMR (75 MHz, $\left.\mathrm{CD}_{2} \mathrm{Cl}_{2}\right): \delta(\mathrm{ppm}) 164.6(\mathrm{C}), 153.1(\mathrm{C}), 133.7(\mathrm{CH}), 133.5(\mathrm{CH}), 130.1(2 \mathrm{CH}), 130.0(\mathrm{CH}), 129.3(\mathrm{C}), 128.6(2 \mathrm{CH})$, $125.8(\mathrm{CH}), 122.5(\mathrm{CH}), 117.3(\mathrm{C}), 88.9(\mathrm{C}), 11.6(\mathrm{C})$.

\section{2-(iodoethynyl)phenyl 4-methoxybenzoate (1f)}<smiles>COc1ccc(C(=O)Oc2ccccc2C#CI)cc1</smiles>

Chemical Formula: $\mathrm{C}_{16} \mathrm{H}_{11} \mathrm{IO}_{3}$

Physical State: White solid, m.p.: $93-94 \stackrel{\circ}{\circ}$

Yield: $92 \%$

HRMS calcd. for $\mathrm{C}_{16} \mathrm{H}_{11} \mathrm{INaO}_{3}(\mathrm{M}+\mathrm{Na}): 400.9645$

HRMS (ESI) found: 400.9645

${ }^{1} \mathrm{H}$ NMR $\left(300 \mathrm{MHz}, \mathrm{CD}_{2} \mathrm{Cl}_{2}\right): \delta(\mathrm{ppm}) 8.23(\mathrm{~d}, J=8.1 \mathrm{~Hz}, 2 \mathrm{H}), 7.58(\mathrm{~d}, J=7.0 \mathrm{~Hz}, 1 \mathrm{H}), 7.47(\mathrm{t}, J=7.0 \mathrm{~Hz}, 1 \mathrm{H}), 7.31(\mathrm{~d}, J=8.1 \mathrm{~Hz}$, $2 \mathrm{H}), 7.09(\mathrm{~d}, J=8.1 \mathrm{~Hz}, 2 \mathrm{H}), 3.94(\mathrm{~s}, 3 \mathrm{H})$.

${ }^{13} \mathrm{C}$ NMR (75 MHz, $\left.\mathbf{C D}_{2} \mathrm{Cl}_{2}\right)$ : $\delta(\mathrm{ppm}) 164.3(\mathrm{C}), 164.1(\mathrm{C}), 153.2(\mathrm{C}), 133.5(\mathrm{CH}), 132.4(2 \mathrm{CH}), 130.0(\mathrm{CH}), 125.7(\mathrm{CH}), 122.7(\mathrm{CH})$, $121.5(\mathrm{C}), 117.4(\mathrm{C}), 114.0(2 \mathrm{CH}), 89.1(\mathrm{C}), 55.6\left(\mathrm{CH}_{3}\right), 11.9(\mathrm{C})$. 
<smiles>O=C(Oc1ccccc1C#CI)c1ccc(Br)cc1</smiles>

Chemical Formula: $\mathrm{C}_{15} \mathrm{H}_{8} \mathrm{BrlO}_{2}$

Physical State: White solid, m.p.: $129-130^{\circ} \mathrm{C}$

Yield: $94 \%$

HRMS calcd. for $\mathrm{C}_{15} \mathrm{H}_{8} \mathrm{BrINaO}_{2}(\mathrm{M}+\mathrm{Na}): 448.8645$

HRMS (ESI) found: 448.8644

${ }^{1} \mathrm{H}$ NMR $\left(400 \mathrm{MHz}, \mathrm{CD}_{2} \mathrm{Cl}_{2}\right): \delta(\mathrm{ppm}) 8.12\left(\mathrm{AA}^{\prime}, 2 \mathrm{H}\right), 7.74(\mathrm{XX}, 2 \mathrm{H}), 7.56(\mathrm{dd}, J=8.0,1.6 \mathrm{~Hz}, 1 \mathrm{H}), 7.48-7.44(\mathrm{~m}, 1 \mathrm{H}), 7.32-7.28$ $(\mathrm{m}, 2 \mathrm{H})$.

${ }^{13} \mathrm{C}$ NMR (100 MHz, $\left.\mathrm{CD}_{2} \mathrm{Cl}_{2}\right)$ : $\delta(\mathrm{ppm}) 163.9(\mathrm{C}), 152.9(\mathrm{C}), 133.5(\mathrm{CH}), 132.3(2 \mathrm{CH}), 131.7(2 \mathrm{CH}), 130.0(\mathrm{CH}), 128.8(\mathrm{C}), 128.3(\mathrm{C})$, $126.0(\mathrm{CH}), 122.3(\mathrm{CH}), 117.2(\mathrm{C}), 88.8(\mathrm{C}), 11.8(\mathrm{C})$.

\section{4-chloro-2-(iodoethynyl)phenyl benzoate (1h)}<smiles>O=C(Oc1ccc(Cl)cc1C#CI)c1ccccc1</smiles>

Chemical Formula: $\mathrm{C}_{15} \mathrm{H}_{8} \mathrm{ClIO}_{2}$

Physical State: Pale yellow solid, m.p.: $131-132 \stackrel{\circ}{ } \mathrm{C}$

Yield: $92 \%$

HRMS calcd. for $\mathrm{C}_{15} \mathrm{H}_{8} \mathrm{ClINaO}(\mathrm{M}+\mathrm{Na}): 404.9150$

HRMS (ESI) found: 404.9149

${ }^{1} \mathrm{H}$ NMR $\left(300 \mathrm{MHz}, \mathrm{CD}_{2} \mathrm{Cl}_{2}\right): \delta(\mathrm{ppm}) 8.25$ (dd, $\left.J=8.3 \mathrm{~Hz}, 1.4,2 \mathrm{H}\right), 7.73(\mathrm{t}, J=7.4,1 \mathrm{H}), 7.60$ (t, $\left.J=7.5,2 \mathrm{H}\right), 7.54(\mathrm{~d}, J=2.6,1 \mathrm{H})$, $7.44(\mathrm{dd}, J=8.7,2.6,1 \mathrm{H}), 7.27(\mathrm{~d}, J=8.7,1 \mathrm{H})$.

${ }^{13} \mathrm{C}$ NMR (75 MHz, $\left.\mathrm{CD}_{2} \mathrm{Cl}_{2}\right)$ : $\delta(\mathrm{ppm}) 164.4(\mathrm{C}), 151.7(\mathrm{C}), 133.9(\mathrm{CH}), 133.0(\mathrm{CH}), 130.9(\mathrm{C}), 130.2(2 \mathrm{CH}), 130.0(\mathrm{CH}), 129.0(\mathrm{C})$, 128.7 (2 CH), $123.8(\mathrm{CH}), 118.8(\mathrm{C}), 87.7(\mathrm{C}), 13.9(\mathrm{C})$.

\section{ethyl 4-(benzoyloxy)-3-(iodoethynyl)benzoate (1i)}<smiles>CCOC(=O)c1ccc(OC(=O)c2ccccc2)c(C#CI)c1</smiles>

Chemical Formula: $\mathrm{C}_{18} \mathrm{H}_{13} \mathrm{IO}_{4}$

Physical State: Pale yellow solid, m.p.: $116 \stackrel{\circ}{\circ}$

Yield: $57 \%$

HRMS calcd. for $\mathrm{C}_{18} \mathrm{H}_{13} \mathrm{INaO}_{4}(\mathrm{M}+\mathrm{Na}): 442.9751$

HRMS (ESI) found: 442.9751

${ }^{1} \mathrm{H}$ NMR $\left(300 \mathrm{MHz}, \mathrm{CD}_{2} \mathrm{Cl}_{2}\right)$ : $\delta(\mathrm{ppm}) 8.28-8.24(\mathrm{~m}, 3 \mathrm{H}), 8.11(\mathrm{dd}, J=8.5,2.1 \mathrm{~Hz}, 1 \mathrm{H}), 7.73(\mathrm{~m}, 1 \mathrm{H}), 7.60(\mathrm{~m}, 2 \mathrm{H}), 7.44(\mathrm{~d}$, $J=8.5 \mathrm{~Hz}, 1 \mathrm{H}), 4.42(\mathrm{q}, J=7.1 \mathrm{~Hz}, 2 \mathrm{H}), 1.44(\mathrm{t}, J=7.1 \mathrm{~Hz}, 3 \mathrm{H})$.

${ }^{13} \mathrm{C}$ NMR (75 MHz, $\left.\mathrm{CD}_{2} \mathrm{Cl}_{2}\right)$ : $\delta(\mathrm{ppm}) 164.9(\mathrm{C}), 164.1(\mathrm{C}), 156.3(\mathrm{C}), 134.9(\mathrm{CH}), 134.0(\mathrm{CH}), 131.1(\mathrm{CH}), 130.3(2 \mathrm{CH}), 128.9(\mathrm{C})$, $128.7(2 \mathrm{CH}), 128.4(\mathrm{C}), 122.6(\mathrm{CH}), 117.6(\mathrm{C}), 88.3(\mathrm{C}), 61.4\left(\mathrm{CH}_{2}\right), 14.1\left(\mathrm{CH}_{3}\right), 13.5(\mathrm{C})$. 
<smiles>Cc1ccc(OC(=O)c2ccccc2)c(C#CI)c1</smiles>

Chemical Formula: $\mathrm{C}_{16} \mathrm{H}_{11} \mathrm{IO}_{2}$

Physical State: White solid, m.p.: $71^{\circ} \mathrm{C}$

Yield: $86 \%$

HRMS calcd. for $\mathrm{C}_{16} \mathrm{H}_{11} \mathrm{INaO}_{2}(\mathrm{M}+\mathrm{Na}): 384.9696$

HRMS (ESI) found: 384.9695

${ }^{1} \mathrm{H}$ NMR (400 MHz, $\mathrm{CD}_{2} \mathrm{Cl}_{2}$ ): $\delta(\mathrm{ppm}) 8.24(\mathrm{~d}, J=8.3 \mathrm{~Hz}, 2 \mathrm{H}), 7.71(\mathrm{t}, J=7.7 \mathrm{~Hz}, 1 \mathrm{H}), 7.59(\mathrm{t}, J=7.7 \mathrm{~Hz}, 2 \mathrm{H}), 7.37(\mathrm{~s}, 1 \mathrm{H}), 7.26(\mathrm{dd}$, $J=8.3,2.1 \mathrm{~Hz}, 1 \mathrm{H}), 7.18(\mathrm{~d}, J=8.3 \mathrm{~Hz}, 1 \mathrm{H}), 2.38(\mathrm{~s}, 3 \mathrm{H})$.

${ }^{13} \mathrm{C}$ NMR (100 MHz, $\left.\mathrm{CD}_{2} \mathrm{Cl}_{2}\right): \delta(\mathrm{ppm}) 164.8(\mathrm{C}), 150.8(\mathrm{C}), 135.8(\mathrm{C}), 133.8(\mathrm{CH}), 133.6(\mathrm{CH}), 130.7(\mathrm{CH}), 130.1(2 \mathrm{CH}), 129.4(\mathrm{C})$, $128.6(2 \mathrm{CH}), 122.1(\mathrm{CH}), 116.8(\mathrm{C}), 83.1(\mathrm{C}), 20.3\left(\mathrm{CH}_{3}\right), 10.9(\mathrm{C})$.

\section{$\underline{\text { 2-(iodoethynyl)-4,6-dimethylphenyl benzoate (1k) }}$}<smiles>Cc1cc(C)c(OC(=O)c2ccccc2)c(C#CI)c1</smiles>

Chemical Formula: $\mathrm{C}_{17} \mathrm{H}_{13} \mid \mathrm{O}_{2}$

Physical State: Yellow solid, m.p.: $150-151^{\circ} \mathrm{C}$

Yield: $89 \%$

HRMS calcd. for $\mathrm{C}_{17} \mathrm{H}_{13} \mathrm{INaO}_{2}(\mathrm{M}+\mathrm{Na}): 398.9852$

HRMS (ESI) found: 398.9850

${ }^{1} \mathrm{H}$ NMR (400 MHz, $\left.\mathbf{C D}_{2} \mathrm{Cl}_{2}\right): \delta(\mathrm{ppm}) 8.25(\mathrm{~d}, J=8.1 \mathrm{~Hz}, 2 \mathrm{H}), 7.71(\mathrm{t}, J=7.4 \mathrm{~Hz}, 1 \mathrm{H}), 7.59(\mathrm{t}, J=7.7 \mathrm{~Hz}, 2 \mathrm{H}), 7.20(\mathrm{~s}, 1 \mathrm{H})$, $7.14(\mathrm{~s}, 1 \mathrm{H}), 2.34(\mathrm{~s}, 3 \mathrm{H}), 2.20(\mathrm{~s}, 3 \mathrm{H})$.

${ }^{13} \mathrm{C}$ NMR (100 MHz, $\mathbf{C D}_{2} \mathrm{Cl}_{2}$ ): $\delta(\mathrm{ppm}) 164.6(\mathrm{C}), 149.5(\mathrm{C}), 135.6(\mathrm{C}), 133.6(\mathrm{CH}), 132.7(\mathrm{CH}), 131.3(\mathrm{CH}), 131.0(\mathrm{C}), 130.2(2 \mathrm{CH})$, $129.3(\mathrm{C}), 128.7(2 \mathrm{CH}), 117.0(\mathrm{C}), 89.5(\mathrm{C}), 20.3\left(\mathrm{CH}_{3}\right), 15.9\left(\mathrm{CH}_{3}\right), 10.1(\mathrm{C})$.

\section{2-(iodoethynyl)phenyl furan-2-carboxylate (11)}<smiles>O=C(Oc1ccccc1C#CI)c1ccco1</smiles>

Chemical Formula: $\mathrm{C}_{13} \mathrm{H}_{7} \mathrm{IO}_{3}$

Physical State: White solid, m.p.: $84-86^{\circ} \mathrm{C}$

Yield: $51 \%$

HRMS calcd. for $\mathrm{C}_{13} \mathrm{H}_{8} \mathrm{IO}_{3}(\mathrm{M}+\mathrm{H}): 338.9513$

HRMS (ESI) found: 338.9513

${ }^{1} \mathrm{H}$ NMR (300 MHz, $\left.\mathrm{CD}_{2} \mathrm{Cl}_{2}\right): \delta(\mathrm{ppm}) 7.78(\mathrm{dd}, J=1.7,0.8 \mathrm{~Hz}, 1 \mathrm{H}), 7.57$ (dd, $\left.J=8.1 \mathrm{~Hz}, 1.7,1 \mathrm{H}\right), 7.49(\mathrm{dd}, J=3.5,0.8 \mathrm{~Hz}, 1 \mathrm{H})$, $7.45(\mathrm{dd}, J=7.5,1.7 \mathrm{~Hz}, 1 \mathrm{H}), 7.30(\mathrm{~m}, 2 \mathrm{H}), 6.69(\mathrm{dd}, J=3.5,1.7 \mathrm{~Hz}, 1 \mathrm{H})$.

${ }^{13} \mathrm{C}$ NMR (75 MHz, $\left.\mathbf{C D}_{2} \mathrm{Cl}_{2}\right)$ : $\delta(\mathrm{ppm}) 156.2(\mathrm{C}), 152.2(\mathrm{C}), 147.6(\mathrm{CH}), 143.7(\mathrm{C}), 133.7(\mathrm{CH}), 130.1(\mathrm{CH}), 126.1(\mathrm{CH}), 122.5(\mathrm{CH})$, $119.9(\mathrm{CH}), 117.4(\mathrm{C}), 112.29(\mathrm{CH}), 88.8(\mathrm{C}), 12.25(\mathrm{C})$. 
<smiles>O=C(Oc1ccccc1C#CI)c1cccs1</smiles>

Chemical Formula: $\mathrm{C}_{13} \mathrm{H}_{7} \mathrm{IO}_{2} \mathrm{~S}$

Physical State: Yellow solid, m.p.: $79-80 \stackrel{\circ}{\mathrm{C}}$

Yield: $52 \%$

HRMS calcd. for $\mathrm{C}_{13} \mathrm{H}_{8} \mathrm{IO}_{2} \mathrm{~S}(\mathrm{M}+\mathrm{H}): 354.9284$

HRMS (ESI) found: 354.9286

${ }^{1} \mathrm{H}$ NMR (400 MHz, CD $\left.\mathrm{Cl}_{2}\right)$ : $\delta(\mathrm{ppm}) 8.06(\mathrm{~d}, J=4.4 \mathrm{~Hz}, 1 \mathrm{H}), 7.75(\mathrm{~d}, J=4.4 \mathrm{~Hz}, 1 \mathrm{H}), 7.56(\mathrm{~d}, J=7.6 \mathrm{~Hz}, 1 \mathrm{H}), 7.44(\mathrm{t}, J=7.6 \mathrm{~Hz}$, $1 \mathrm{H}), 7.33-7.23(\mathrm{~m}, 3 \mathrm{H})$

${ }^{13} \mathrm{C}$ NMR (75 MHz, $\left.\mathbf{C D}_{2} \mathrm{Cl}_{2}\right)$ : $\delta(\mathrm{ppm}) 160.0(\mathrm{C}), 152.7(\mathrm{C}), 135.1(\mathrm{CH}), 134.1(\mathrm{CH}), 133.6(\mathrm{CH}), 132.4(\mathrm{C}), 130.1(\mathrm{CH}), 128.3(\mathrm{CH})$, $126.1(\mathrm{CH}), 122.6(\mathrm{CH}), 117.4(\mathrm{C}), 89.0(\mathrm{C}), 12.8(\mathrm{C})$.

\section{2-(iodoethynyl)phenyl cinnamate (1n)}<smiles>O=C(/C=C/c1ccccc1)Oc1ccccc1C#CI</smiles>

Chemical Formula: $\mathrm{C}_{17} \mathrm{H}_{11} \mathrm{IO}_{2}$

Physical State: White solid, m.p.: $137-139 \stackrel{\circ}{ } \mathrm{C}$

Yield: $59 \%$

HRMS calcd. for $\mathrm{C}_{17} \mathrm{H}_{11} \mathrm{INaO}_{2}(\mathrm{M}+\mathrm{Na}): 396.9696$

HRMS (ESI) found: 396.9697

${ }^{1} \mathrm{H}$ NMR $\left(400 \mathrm{MHz}, \mathbf{C D}_{2} \mathrm{Cl}_{2}\right): \delta(\mathrm{ppm}) 7.98(\mathrm{~d}, J=16.0 \mathrm{~Hz}, 1 \mathrm{H}), 7.68-7.71(\mathrm{~m}, 2 \mathrm{H}), 7.56(\mathrm{~d}, J=7.5 \mathrm{~Hz}, 1 \mathrm{H}), 7.50-7.43(\mathrm{~m}, 4 \mathrm{H})$, $7.30-7.24(\mathrm{~m}, 2 \mathrm{H}), 6.74(\mathrm{~d}, J=16.0 \mathrm{~Hz}, 1 \mathrm{H})$

${ }^{13} \mathrm{C}$ NMR (100 MHz, $\left.\mathbf{C D}_{2} \mathrm{Cl}_{2}\right)$ : $\delta(\mathrm{ppm}) 164.7(\mathrm{C}), 152.9(\mathrm{C}), 146.9(\mathrm{CH}), 134.2(\mathrm{C}), 133.6(\mathrm{CH}), 130.8(\mathrm{CH}), 130.0(\mathrm{CH}), 129.0(2 \mathrm{CH})$, $128.4(2 \mathrm{CH}), 125.8(\mathrm{CH}), 122.5(\mathrm{CH}), 117.4(\mathrm{C}), 116.8(\mathrm{CH}), 89.1(\mathrm{C}), 11.7(\mathrm{C})$.

\section{2-(iodoethynyl)phenyl 3-methylbut-2-enoate (10)}<smiles>CC(C)=CC(=O)Oc1ccccc1C#CI</smiles>

Chemical Formula: $\mathrm{C}_{13} \mathrm{H}_{11} \mathrm{IO}_{2}$

Physical State: Yellow oil

Yield: $87 \%$

HRMS calcd. for $\mathrm{C}_{13} \mathrm{H}_{11} \mathrm{INaO}_{2}(\mathrm{M}+\mathrm{Na}): 348.9696$

HRMS (ESI) found: 348.9691

${ }^{1} \mathrm{H}$ NMR (300 MHz, $\left.\mathbf{C D}_{2} \mathrm{Cl}_{2}\right): \delta(\mathrm{ppm}) 7.52(\mathrm{dd}, J=7.7,1.5 \mathrm{~Hz}, 1 \mathrm{H}), 7.42(\mathrm{td}, J=7.9,1.7 \mathrm{~Hz}, 1 \mathrm{H}), 7.25(\mathrm{td}, J=7.6,1.2 \mathrm{~Hz}, 1 \mathrm{H})$, $7.15(\mathrm{dd}, J=8.1,0.9 \mathrm{~Hz}, 1 \mathrm{H}), 6.01-5.59(\mathrm{~m}, 1 \mathrm{H}), 2.28(\mathrm{~s}, 3 \mathrm{H}), 2.06(\mathrm{~s}, 3 \mathrm{H})$.

${ }^{13} \mathrm{C}$ NMR (75 MHz, $\left.\mathrm{CD}_{2} \mathrm{Cl}_{2}\right): \delta(\mathrm{ppm}) 164.0(\mathrm{C}), 160.5(\mathrm{C}), 153.0(\mathrm{C}), 133.5(\mathrm{CH}), 129.9(\mathrm{CH}), 125.4(\mathrm{CH}), 122.6(\mathrm{CH}), 117.5(\mathrm{C})$, $114.6(\mathrm{CH}), 89.3(\mathrm{C}), 27.3\left(\mathrm{CH}_{3}\right), 20.3\left(\mathrm{CH}_{3}\right), 11.0(\mathrm{C})$. 
<smiles>COc1ccc2cc([C@@H](C)C(=O)Oc3ccccc3C#CI)ccc2c1</smiles>

Chemical Formula: $\mathrm{C}_{22} \mathrm{H}_{17} \mathrm{IO}_{3}$

Physical State: Brown solid, m.p.: $86-89 \stackrel{\circ}{\mathrm{C}}$

Yield: $85 \%$

HRMS calcd. for $\mathrm{C}_{22} \mathrm{H}_{17} \mathrm{INaO}_{3}(\mathrm{M}+\mathrm{Na}): 479.0115$

HRMS (ESI) found: 479.0114

${ }^{1} \mathrm{H}$ NMR (300 MHz, $\left.\mathrm{CD}_{2} \mathrm{Cl}_{2}\right)$ : $\delta(\mathrm{ppm}) 7.85-7.79(\mathrm{~m}, 3 \mathrm{H}), 7.57(\mathrm{~d}, J=8.6 \mathrm{~Hz}, 1 \mathrm{H}), 7.49(\mathrm{dd}, J=7.6,1.2 \mathrm{~Hz}, 1 \mathrm{H}), 7.37(\mathrm{t}, J=7.6 \mathrm{~Hz}$, $1 \mathrm{H}), 7.26-7.17(\mathrm{~m}, 3 \mathrm{H}), 7.05(\mathrm{~d}, J=8.0 \mathrm{~Hz}, 1 \mathrm{H}), 4.19(\mathrm{q}, J=7.2 \mathrm{~Hz}, 1 \mathrm{H}), 3.95(\mathrm{~s}, 3 \mathrm{H}), 1.77(\mathrm{~d}, J=7.2 \mathrm{~Hz}, 3 \mathrm{H})$.

${ }^{13} \mathrm{C}$ NMR (100 MHz, $\left.\mathrm{CD}_{2} \mathrm{Cl}_{2}\right)$ : $\delta(\mathrm{ppm}) 172.5(\mathrm{C}), 157.8(\mathrm{C}), 152.5(\mathrm{C}), 134.9(\mathrm{C}), 134.0(\mathrm{C}), 133.7(\mathrm{CH}), 129.9(\mathrm{CH}), 129.4(\mathrm{CH}), 129.1$ (C), $127.3(\mathrm{CH}), 126.4(\mathrm{CH}), 126.3(\mathrm{CH}), 125.8(\mathrm{CH}), 122.2(\mathrm{CH}), 118.9(\mathrm{CH}), 117.4(\mathrm{C}), 105.6(\mathrm{CH}), 88.8(\mathrm{C}), 55.3\left(\mathrm{CH}_{3}\right), 45.5(\mathrm{CH})$, $18.7\left(\mathrm{CH}_{3}\right), 11.7(\mathrm{C})$.

er: 89:11 determined by HPLC (for analytical conditions and chromatograms see HPLC data of starting materials 


\subsection{Characterization data for products (2)}

\section{1-(3-iodobenzofuran-2-yl)-2-phenylethan-1-one (2a)}<smiles>O=C(Cc1ccccc1)c1oc2ccccc2c1I</smiles>

Chemical Formula: $\mathrm{C}_{16} \mathrm{H}_{11} \mathrm{IO}_{2}$

Physical State: Pale yellow solid, m.p.: $115-117^{\circ} \mathrm{C}$

Yield: $82 \%$

HRMS calcd. for $\mathrm{C}_{16} \mathrm{H}_{11} \mathrm{INaO}_{2}(\mathrm{M}+\mathrm{Na}): 384.9696$

HRMS (ESI) found: 384.9696

${ }^{1} \mathrm{H}$ NMR (400 MHz, $\left.\mathrm{CD}_{2} \mathrm{Cl}_{2}\right): \delta(\mathrm{ppm}) 7.62-7.59(\mathrm{~m}, 3 \mathrm{H}), 7.43-7.33(\mathrm{~m}, 6 \mathrm{H}), 4.40(\mathrm{~s}, 2 \mathrm{H})$.

${ }^{13} \mathrm{C}$ NMR (100 MHz, $\left.\mathrm{CD}_{2} \mathrm{Cl}_{2}\right)$ : $\delta(\mathrm{ppm}) 188.8(\mathrm{C}), 154.4(\mathrm{C}), 149.1(\mathrm{C}), 133.8(\mathrm{C}), 131.6(\mathrm{C}), 129.9(2 \mathrm{CH}), 129.4(\mathrm{CH}), 128.5(2 \mathrm{CH})$, $127.0(\mathrm{CH}), 124.5(\mathrm{CH}), 123.8(\mathrm{CH}), 112.4(\mathrm{CH}), 71.7(\mathrm{C}), 46.1\left(\mathrm{CH}_{2}\right)$.

\section{1-(3-iodobenzofuran-2-yl)ethan-1-one (2b)}<smiles>CC(=O)c1oc2ccccc2c1I</smiles>

Chemical Formula: $\mathrm{C}_{10} \mathrm{H}_{7} \mathrm{OO}_{2}$

Physical State: Pale yellow solid, m.p.: $127^{\circ} \mathrm{C}$

Yield: $78 \%$

HRMS calcd. for $\mathrm{C}_{10} \mathrm{H}_{7} \mathrm{INaO}_{2}(\mathrm{M}+\mathrm{Na}): 308.9383$

HRMS (ESI) found: 308.9389

${ }^{1} \mathrm{H}$ NMR (300 MHz, $\left.\mathrm{CD}_{2} \mathrm{Cl}_{2}\right)$ : $\delta(\mathrm{ppm}) 7.61-7.56(\mathrm{~m}, 3 \mathrm{H}), 7.46-7.40(\mathrm{~m}, 1 \mathrm{H}), 2.69(\mathrm{~s}, 3 \mathrm{H})$.

${ }^{13} \mathrm{C}$ NMR (75 MHz, $\left.\mathrm{CD}_{2} \mathrm{Cl}_{2}\right): \delta(\mathrm{ppm}) 189.0(\mathrm{C}), 154.3(\mathrm{C}), 149.6(\mathrm{C}), 131.5(\mathrm{C}), 129.2(\mathrm{CH}), 124.4(\mathrm{CH}), 123.8(\mathrm{CH}), 112.3(\mathrm{CH})$, $70.4(\mathrm{C}), 27.4\left(\mathrm{CH}_{3}\right)$.

\section{1-(3-iodobenzofuran-2-yl)-3-methylbutan-1-one (2c)}<smiles>CC(C)CC(=O)c1oc2ccccc2c1I</smiles>

Chemical Formula: $\mathrm{C}_{13} \mathrm{H}_{13} \mid \mathrm{O}_{2}$

Physical State: Yellow needles, m.p.: $62{ }^{\circ} \mathrm{C}$

Yield: $77 \%$

HRMS calcd. for $\mathrm{C}_{13} \mathrm{H}_{13} \mathrm{INaO}_{2}(\mathrm{M}+\mathrm{Na}): 350.9852$

HRMS (ESI) found: 350.9851

${ }^{1} \mathrm{H}$ NMR $\left(300 \mathbf{M H z} \mathbf{C D C l}_{3}\right): \delta(\mathrm{ppm}) 7.61-7.58(\mathrm{~m}, 3 \mathrm{H}), 7.43(\mathrm{~m}, 1 \mathrm{H}), 2.96(\mathrm{~d}, J=6.9 \mathrm{~Hz}, 2 \mathrm{H}), 2.36($ non, $J=13.4,6.7 \mathrm{~Hz}, 1 \mathrm{H})$, $1.06(\mathrm{~d}, J=6.7 \mathrm{~Hz}, 6 \mathrm{H})$

${ }^{13} \mathrm{C}$ NMR (100 MHz, $\left.\mathbf{C D}_{2} \mathrm{Cl}_{2}\right): \delta(\mathrm{ppm}) 191.4(\mathrm{C}), 154.2(\mathrm{C}), 149.6(\mathrm{C}), 131.5(\mathrm{C}), 129.1(\mathrm{CH}), 124.4(\mathrm{CH}), 123.7(\mathrm{CH}), 112.3(\mathrm{CH})$, $70.1(\mathrm{C}), 48.3\left(\mathrm{CH}_{2}\right), 24.7(\mathrm{CH}), 22.4\left(2 \mathrm{CH}_{3}\right)$.

\section{1-(3-iodobenzofuran-2-yl)-3-phenylpropan-1-one (2d)}<smiles>O=C(CCc1ccccc1)c1oc2ccccc2c1I</smiles>

Chemical Formula: $\mathrm{C}_{17} \mathrm{H}_{13} \mathrm{lO}$

Physical State: Yellow solid, m.p.: $84-85 \stackrel{\circ}{\circ}$

Yield: $80 \%$

HRMS calcd. for $\mathrm{C}_{17} \mathrm{H}_{13} \mathrm{INaO}_{2}(\mathrm{M}+\mathrm{Na}): 398.9852$

HRMS (ESI) found: 398.9848

${ }^{1} \mathrm{H}$ NMR $\left(300 \mathrm{MHz}, \mathrm{CD}_{2} \mathrm{Cl}_{2}\right): \delta(\mathrm{ppm}) 7.61-7.57(\mathrm{~m}, 3 \mathrm{H}), 7.45-7.23(\mathrm{~m}, 6 \mathrm{H}), 3.43(\mathrm{t}, J=7.6 \mathrm{~Hz}, 2 \mathrm{H}), 3.12(\mathrm{t}, J=7.6 \mathrm{~Hz}, 2 \mathrm{H})$.

${ }^{13} \mathrm{C}$ NMR (75 MHz, $\left.\mathbf{C D}_{2} \mathrm{Cl}_{2}\right)$ : $\delta(\mathrm{ppm}) 190.6(\mathrm{C}), 154.2(\mathrm{C}), 149.3(\mathrm{C}), 141.1(\mathrm{C}), 131.5(\mathrm{C}), 129.2(\mathrm{CH}), 128.4(4 \mathrm{CH}), 126.1(\mathrm{CH})$, $124.4(\mathrm{CH}), 123.7(\mathrm{CH}), 112.3(\mathrm{CH}), 70.2(\mathrm{C}), 41.3\left(\mathrm{CH}_{2}\right), 29.4\left(\mathrm{CH}_{2}\right)$. 
<smiles>O=C(c1ccccc1)c1oc2ccccc2c1I</smiles>

Chemical Formula: $\mathrm{C}_{15} \mathrm{H}_{9} \mathrm{IO}_{2}$

Physical State: Yellow oil

Yield: $76 \%$

HRMS calcd. for $\mathrm{C}_{15} \mathrm{H}_{9} \mathrm{INaO}_{2}(\mathrm{M}+\mathrm{Na}): 370.9539$

HRMS (ESI) found: 370.9541

${ }^{1} \mathrm{H}$ NMR $\left(400 \mathrm{MHz}, \mathrm{CD}_{2} \mathrm{Cl}_{2}\right): \delta(\mathrm{ppm}) 8.13(\mathrm{~d}, J=7.5 \mathrm{~Hz}, 2 \mathrm{H}), 7.67(\mathrm{t}, J=9.0 \mathrm{~Hz}, 2 \mathrm{H}), 7.62-7.59(\mathrm{~m}, 4 \mathrm{H}), 7.47(\mathrm{~s}, 1 \mathrm{H})$.

${ }^{13} \mathrm{C}$ NMR (100 MHz, $\left.\mathrm{CD}_{2} \mathrm{Cl}_{2}\right)$ : $\delta(\mathrm{ppm}) 184.0(\mathrm{C}), 154.5(\mathrm{C}), 149.9(\mathrm{C}), 136.7(\mathrm{C}), 133.1(\mathrm{CH}), 131.4(\mathrm{C}), 129.9(2 \mathrm{CH}), 129.2(\mathrm{CH})$, $128.4(2 \mathrm{CH}), 124.6(\mathrm{CH}), 123.8(\mathrm{CH}), 112.4(\mathrm{CH}), 73.7(\mathrm{C})$.

\section{(3-iodobenzofuran-2-yl)(4-methoxyphenyl)methanone (2f)}<smiles>COc1ccc(C(=O)c2oc3ccccc3c2I)cc1</smiles>

Chemical Formula: $\mathrm{C}_{16} \mathrm{H}_{11} \mathrm{IO}_{3}$

Physical State: Pale yellow solid, m.p.: $128-130 \stackrel{\circ}{ } \mathrm{C}$

Yield: $43 \%$

HRMS calcd. for $\mathrm{C}_{16} \mathrm{H}_{11} \mathrm{INaO}_{2}(\mathrm{M}+\mathrm{Na}): 400.9645$

HRMS (ESI) found: 400.9641

${ }^{1} \mathrm{H}$ NMR $\left(300 \mathrm{MHz}, \mathrm{CD}_{2} \mathrm{Cl}_{2}\right): \delta(\mathrm{ppm}) 8.18(\mathrm{~d}, J=9.0 \mathrm{~Hz}, 2 \mathrm{H}), 7.67-7.61(\mathrm{~m}, 3 \mathrm{H}), 7.50-7.45(\mathrm{~m}, 1 \mathrm{H}), 7.08(\mathrm{~d}, J=9.0 \mathrm{~Hz}, 2 \mathrm{H})$, $3.95(\mathrm{~s}, 3 \mathrm{H})$.

${ }^{13} \mathrm{C}$ NMR (75 MHz, $\left.\mathbf{C D}_{2} \mathrm{Cl}_{2}\right): \delta(\mathrm{ppm}) 182.3(\mathrm{C}), 163.8(\mathrm{C}), 154.4(\mathrm{C}), 150.3(\mathrm{C}), 132.5(2 \mathrm{CH}), 131.3(\mathrm{C}), 129.3(\mathrm{C}), 128.8(\mathrm{CH})$, $124.4(\mathrm{CH}), 123.6(\mathrm{CH}), 113.7(2 \mathrm{CH}), 112.3(\mathrm{CH}), 72.8(\mathrm{C}), 55.6\left(\mathrm{CH}_{3}\right)$.

\section{(4-bromophenyl)(3-iodobenzofuran-2-yl)methanone (2g)}<smiles>O=C(c1ccc(Br)cc1)c1oc2ccccc2c1I</smiles>

Chemical Formula: $\mathrm{C}_{15} \mathrm{H}_{8} \mathrm{BrlO}_{2}$

Physical State: Yellow solid, m.p.: $102-103^{\circ} \mathrm{C}$

Yield: $66 \%$

HRMS calcd. for $\mathrm{C}_{15} \mathrm{H}_{8} \mathrm{BrINaO}_{2}(\mathrm{M}+\mathrm{Na}): 448.8645$

HRMS (ESI) found: 448.8646

${ }^{1} \mathrm{H}$ NMR $\left(400 \mathrm{MHz}, \mathrm{CD}_{2} \mathrm{Cl}_{2}\right): \delta(\mathrm{ppm}) 8.02(\mathrm{~d}, J=8.5 \mathrm{~Hz}, 2 \mathrm{H}), 7.73(\mathrm{~d}, J=8.4 \mathrm{~Hz}, 2 \mathrm{H}), 7.65(\mathrm{dd}, J=7.9,1.0 \mathrm{~Hz}, 1 \mathrm{H}), 7.62-7.60(\mathrm{~m}$, $2 \mathrm{H}), 7.49-7.45(\mathrm{~m}, 1 \mathrm{H})$.

${ }^{13} \mathrm{C}$ NMR (100 MHz, $\left.\mathrm{CD}_{2} \mathrm{Cl}_{2}\right)$ : $\delta(\mathrm{ppm}) 182.8(\mathrm{C}), 154.5(\mathrm{C}), 149.5(\mathrm{C}), 135.4(\mathrm{C}), 131.7(2 \mathrm{CH}), 131.5(2 \mathrm{CH}), 131.4(\mathrm{C}), 129.4(\mathrm{CH})$, $128.1(\mathrm{C}), 124.6(\mathrm{CH}), 123.8(\mathrm{CH}), 112.4(\mathrm{CH}), 74.3(\mathrm{C})$. 
<smiles>O=C(c1ccccc1)c1oc2ccc(Cl)cc2c1I</smiles>

Chemical Formula: $\mathrm{C}_{15} \mathrm{H}_{8} \mathrm{ClIO}_{2}$

Physical State: Yellow solid, m.p.: $90-91^{\circ} \mathrm{C}$

Yield: $68 \%$

HRMS calcd. for $\mathrm{C}_{15} \mathrm{H}_{8} \mathrm{CIINaO}$ (M+Na): 404.9150

HRMS (ESI) found: 404.9146

${ }^{1} \mathrm{H}$ NMR $\left(400 \mathrm{MHz}, \mathrm{CD}_{2} \mathrm{Cl}_{2}\right): \delta(\mathrm{ppm}) 8.10(\mathrm{~d}, J=6.7 \mathrm{~Hz}, 2 \mathrm{H}), 7.68(\mathrm{~d}, J=7.7 \mathrm{~Hz}, 1 \mathrm{H}), 7.62(\mathrm{~d}, J=12.5 \mathrm{~Hz}, 1 \mathrm{H}), 7.58-7.54(\mathrm{~m}, 4 \mathrm{H})$. ${ }^{13} \mathrm{C}$ NMR (100 MHz, $\mathrm{CD}_{2} \mathrm{Cl}_{2}$ ): $\delta(\mathrm{ppm}) 185.7$ (C), $154.8(\mathrm{C}), 152.9(\mathrm{C}), 138.3(\mathrm{C}), 135.2(\mathrm{CH}), 134.7(\mathrm{C}), 132.2(\mathrm{C}), 131.8(2 \mathrm{CH})$, $131.3(\mathrm{CH}), 130.4(2 \mathrm{CH}), 125.2(\mathrm{CH}), 115.6(\mathrm{CH}), 74.09(\mathrm{C})$.

\section{ethyl 2-benzoyl-3-iodobenzofuran-5-carboxylate (2i)}<smiles>CCOC(=O)c1ccc2oc(C(=O)c3ccccc3)c(I)c2c1</smiles>

Chemical Formula: $\mathrm{C}_{18} \mathrm{H}_{13} \mathrm{IO}_{4}$

Physical State: Yellow solid, m.p.: $135-136^{\circ} \mathrm{C}$

Yield: $72 \%$

HRMS calcd. for $\mathrm{C}_{18} \mathrm{H}_{13} \mathrm{INaO}_{4}(\mathrm{M}+\mathrm{Na}): 442.9751$

HRMS (ESI) found: 442.9751

${ }^{1} \mathrm{H}$ NMR $\left(400 \mathrm{MHz}, \mathrm{CD}_{2} \mathrm{Cl}_{2}\right): \delta(\mathrm{ppm}) 8.33(\mathrm{~s}, 1 \mathrm{H}), 8.26$ (dd, $\left.J=8.8,1.5 \mathrm{~Hz}, 1 \mathrm{H}\right), 8.11$ (dd, $\left.J=8.2,1.2 \mathrm{~Hz}, 2 \mathrm{H}\right), 7.69(\mathrm{t}, J=7.3 \mathrm{~Hz}$, $1 \mathrm{H}), 7.64(\mathrm{~d}, J=8.8 \mathrm{~Hz}, 1 \mathrm{H}), 7.58(\mathrm{t}, J=7.7 \mathrm{~Hz}, 2 \mathrm{H}), 4.45(\mathrm{q}, J=7.1 \mathrm{~Hz}, 2 \mathrm{H}), 1.47(\mathrm{t}, J=7.1 \mathrm{~Hz}, 3 \mathrm{H})$.

${ }^{13} \mathrm{C}$ NMR (100 MHz, $\left.\mathbf{C D}_{2} \mathrm{Cl}_{2}\right): \delta(\mathrm{ppm}) 183.8(\mathrm{C}), 165.6(\mathrm{C}), 156.8(\mathrm{C}), 151.0(\mathrm{C}), 136.4(\mathrm{C}), 133.3(\mathrm{CH}), 131.5(\mathrm{C}), 130.2(\mathrm{CH})$, $129.9(2 \mathrm{CH}), 128.5(2 \mathrm{CH}), 127.5(\mathrm{C}), 126.0(\mathrm{CH}), 112.4(\mathrm{CH}), 73.8(\mathrm{C}), 61.3\left(\mathrm{CH}_{2}\right), 14.2\left(\mathrm{CH}_{3}\right)$.

\section{(3-iodo-5-methylbenzofuran-2-yl)(phenyl)methanone (2i)}<smiles>Cc1ccc2oc(C(=O)c3ccccc3)c(I)c2c1</smiles>

\section{Chemical Formula: $\mathrm{C}_{16} \mathrm{H}_{11} \mathrm{IO}_{2}$}

Physical State: Pale yellow solid, m.p.: $92-94 \stackrel{\circ}{ } \mathrm{C}$

Yield: $76 \%$

HRMS calcd. for $\mathrm{C}_{16} \mathrm{H}_{11} \mathrm{INaO}_{2}(\mathrm{M}+\mathrm{Na}): 384.9696$

HRMS (ESI) found: 384.9698

${ }^{1} \mathrm{H}$ NMR (400 MHz, $\left.\mathrm{CD}_{2} \mathrm{Cl}_{2}\right): \delta(\mathrm{ppm}) 8.11(\mathrm{dd}, J=8.4,1.3 \mathrm{~Hz}, 2 \mathrm{H}), 7.68(\mathrm{t}, J=7.4 \mathrm{~Hz}, 1 \mathrm{H}), 7.57(\mathrm{t}, J=7.6 \mathrm{~Hz}, 2 \mathrm{H}), 7.49(\mathrm{~d}$, $J=8.9 \mathrm{~Hz}, 1 \mathrm{H}), 7.42(\mathrm{~d}, J=7.8 \mathrm{~Hz}, 2 \mathrm{H}), 2.55(\mathrm{~s}, 3 \mathrm{H})$.

${ }^{13} \mathrm{C}$ NMR (100 MHz, $\left.\mathbf{C D}_{2} \mathrm{Cl}_{2}\right): \delta(\mathrm{ppm}) 184.0(\mathrm{C}), 153.0(\mathrm{C}), 150.0(\mathrm{C}), 136.8(\mathrm{C}), 134.6(\mathrm{C}), 132.9(\mathrm{CH}), 131.4(\mathrm{C}), 130.8(\mathrm{CH})$, $129.9(2 \mathrm{CH}), 128.34(2 \mathrm{CH}), 123.1(\mathrm{CH}), 111.9(\mathrm{CH}), 73.4(\mathrm{C}), 21.0\left(\mathrm{CH}_{3}\right)$. 
<smiles>Cc1cc(C)c2oc(C(=O)c3ccccc3)c(I)c2c1</smiles>

\section{Chemical Formula: $\mathrm{C}_{17} \mathrm{H}_{13} / \mathrm{NaO}_{2}$}

Physical State: Yellow needles, m.p.: $95-96^{\circ} \mathrm{C}$ Yield: $85 \%$

HRMS calcd. for $\mathrm{C}_{17} \mathrm{H}_{13} \mathrm{INaO}_{2}(\mathrm{M}+\mathrm{Na}): 398.9852$

HRMS (ESI) found: 398.9848

${ }^{1} \mathrm{H}$ NMR $\left(300 \mathrm{MHz}, \mathrm{CD}_{2} \mathrm{Cl}_{2}\right): \delta(\mathrm{ppm}) 8.16(\mathrm{~d}, J=7.7 \mathrm{~Hz}, 1 \mathrm{H}), 7.71-7.56(\mathrm{~m}, 2 \mathrm{H}), 7.23(\mathrm{~s}, 1 \mathrm{H}), 2.52(\mathrm{~d}, J=12.0 \mathrm{~Hz}, 3 \mathrm{H})$.

${ }^{13} \mathrm{C}$ NMR (75 MHz, $\left.\mathbf{C D}_{2} \mathrm{Cl}_{2}\right)$ : $\delta(\mathrm{ppm}) 183.8$ (C), 152.1 (C), 149.7 (C), 136.9 (C), 134.5 (C), $132.9(\mathrm{CH}), 131.4(\mathrm{CH}), 130.9(\mathrm{C})$, $130.0(2 \mathrm{CH}), 128.4(2 \mathrm{CH}), 122.2(\mathrm{C}), 120.5(\mathrm{CH}), 73.8(\mathrm{C}), 21.1\left(\mathrm{CH}_{3}\right), 14.4\left(\mathrm{CH}_{3}\right)$.

\section{furan-2-yl(3-iodobenzofuran-2-yl)methanone (2l)}<smiles>O=C(c1ccco1)c1oc2ccccc2c1I</smiles>

Chemical Formula: $\mathrm{C}_{13} \mathrm{H}_{7} \mathrm{IO}_{3}$

Physical State: Yellow oil

Yield: $78 \%$

HRMS calcd. for $\mathrm{C}_{13} \mathrm{H}_{7} \mathrm{INaO}_{3}(\mathrm{M}+\mathrm{Na}): 360.9332$

HRMS (ESI) found: 360.9329

${ }^{1} \mathrm{H}$ NMR $\left(400 \mathrm{MHz}, \mathrm{CD}_{2} \mathrm{Cl}_{2}\right): \delta(\mathrm{ppm}) 7.88(\mathrm{dd}, J=3.6,0.6 \mathrm{~Hz}, 1 \mathrm{H}), 7.83(\mathrm{~d}, J=1.6,0.7 \mathrm{~Hz}, 1 \mathrm{H}), 7.66-7.61(\mathrm{~m}, 3 \mathrm{H}), 7.48-7.44(\mathrm{~m}$, $1 \mathrm{H}), 6.72(\mathrm{dd}, J=3.6,1.6,1 \mathrm{H})$.

${ }^{13} \mathrm{C}$ NMR (100 MHz, $\left.\mathbf{C D}_{2} \mathrm{Cl}_{2}\right)$ : $\delta(\mathrm{ppm}) 169.6(\mathrm{C}), 154.5(\mathrm{C}), 150.7(\mathrm{C}), 148.6(\mathrm{C}), 148.0(\mathrm{CH}), 131.3(\mathrm{C}), 129.3(\mathrm{CH}), 124.6(\mathrm{CH})$, $123.7(\mathrm{CH}), 121.8(\mathrm{CH}), 112.5(\mathrm{CH}), 112.3(\mathrm{CH}), 73.3(\mathrm{C})$

\section{(3-iodobenzofuran-2-yl)(thiophen-2-yl)methanone (2m)}<smiles>O=C(c1cccs1)c1oc2ccccc2c1I</smiles>

\section{Chemical Formula: $\mathrm{C}_{13} \mathrm{H}_{7} \mathrm{IO}_{2} \mathrm{~S}$}

Physical State: Yellow solid, m.p.: $119-121^{\circ} \mathrm{C}$

Yield: $75 \%$

HRMS calcd. for $\mathrm{C}_{13} \mathrm{H}_{7} \mathrm{INaO}_{2} \mathrm{~S}(\mathrm{M}+\mathrm{Na}): 376.9104$

HRMS (ESI) found: 376.9100

${ }^{1} \mathrm{H}$ NMR (400 MHz, $\left.\mathrm{CD}_{2} \mathrm{Cl}_{2}\right)$ : $\delta(\mathrm{ppm}) 8.39(\mathrm{dd}, J=3.9,1.3 \mathrm{~Hz}, 1 \mathrm{H}), 7.82(\mathrm{~d}, J=5.2 \mathrm{~Hz}, 1 \mathrm{H}), 7.64-7.57(\mathrm{~m}, 3 \mathrm{H}), 7.43(\mathrm{td}$, $J=7.5,6.9,1.3 \mathrm{~Hz}, 1 \mathrm{H}), 7.27$ (dd, $J=4.9,3.9 \mathrm{~Hz}, 1 \mathrm{H})$.

${ }^{13} \mathrm{C}$ NMR (100 MHz, $\left.\mathrm{CD}_{2} \mathrm{Cl}_{2}\right)$ : $\delta(\mathrm{ppm}) 174.4(\mathrm{C}), 154.4(\mathrm{C}), 148.9(\mathrm{C}), 142.4(\mathrm{C}), 135.1(2 \mathrm{CH}), 131.4(\mathrm{C}), 129.3(\mathrm{CH}), 128.6(\mathrm{CH})$, $124.6(\mathrm{CH}), 123.7(\mathrm{CH}), 112.3(\mathrm{CH}), 73.7(\mathrm{C})$. 


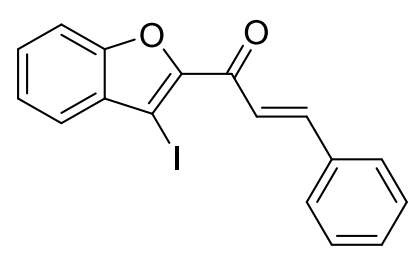

Chemical Formula: $\mathrm{C}_{17} \mathrm{H}_{11} \mathrm{IO}_{2}$

Physical State: Orange solid, m.p.: $118-120^{\circ} \mathrm{C}$

Yield: $65 \%$

HRMS calcd. for $\mathrm{C}_{17} \mathrm{H}_{11} \mathrm{NNaO}_{2}(\mathrm{M}+\mathrm{Na}): 396.9696$

HRMS (ESI) found: 396.9692

${ }^{1} \mathrm{H}$ NMR $\left(400 \mathrm{MHz}, \mathrm{CD}_{2} \mathrm{Cl}_{2}\right): \delta(\mathrm{ppm}) 7.96(\mathrm{~d}, J=15.8 \mathrm{~Hz}, 1 \mathrm{H}), 7.86(\mathrm{~d}, J=15.8 \mathrm{~Hz}, 1 \mathrm{H}), 7.78(\mathrm{dd}, J=6.5,3.0 \mathrm{~Hz}, 2 \mathrm{H}), 7.68-7.59$ $(\mathrm{m}, 3 \mathrm{H}), 7.50-7.43(\mathrm{~m}, 4 \mathrm{H})$.

${ }^{13} \mathrm{C}$ NMR $\left(100 \mathrm{MHz}, \mathbf{C D}_{2} \mathrm{Cl}_{2}\right): \delta(\mathrm{ppm}) 179.8(\mathrm{C}), 154.4(\mathrm{C}), 150.1(\mathrm{C}), 144.6(\mathrm{CH}), 134.8(\mathrm{C}), 131.8(\mathrm{C}), 130.9(\mathrm{CH}), 129.2(\mathrm{CH})$, $129.0(2 \mathrm{CH}), 128.7(2 \mathrm{CH}), 124.5(\mathrm{CH}), 123.7(\mathrm{CH}), 121.4(\mathrm{CH}), 112.3(\mathrm{CH}), 71.6(\mathrm{C})$.

\section{1-(3-iodobenzofuran-2-yl)-3-methylbut-2-en-1-one (20)}<smiles>CC(C)=CC(=O)c1oc2ccccc2c1I</smiles>

Chemical Formula: $\mathrm{C}_{13} \mathrm{H}_{11} \mathrm{IO}_{2}$

Physical State: Yellow solid, m.p.: $108-110^{\circ} \mathrm{C}$

Yield: $81 \%$ (Gram scale: $78 \%$ )

HRMS calcd. for $\mathrm{C}_{13} \mathrm{H}_{11} \mathrm{INaO}_{2}(\mathrm{M}+\mathrm{Na}): 348.9696$

HRMS (ESI) found: 348.9695

${ }^{1} \mathrm{H}$ NMR $\left(400 \mathrm{MHz}, \mathrm{CD}_{2} \mathrm{Cl}_{2}\right): \delta(\mathrm{ppm}) 7.56(\mathrm{t}, J=6.1 \mathrm{~Hz}, 3 \mathrm{H}), 7.41(\mathrm{dt}, J=4.4,2.4 \mathrm{~Hz}, 1 \mathrm{H}), 7.05(\mathrm{~s}, 1 \mathrm{H}), 2.34(\mathrm{~s}, 3 \mathrm{H}), 2.10(\mathrm{~s}, 3 \mathrm{H})$.

${ }^{13} \mathrm{C}$ NMR (100 MHz, $\mathrm{CD}_{2} \mathrm{Cl}_{2}$ ): $\delta(\mathrm{ppm}) 180.7(\mathrm{C}), 160.1(\mathrm{C}), 154.0(\mathrm{C}), 150.3(\mathrm{C}), 131.7(\mathrm{C}), 128.8(\mathrm{CH}), 124.2(\mathrm{CH}), 123.5(\mathrm{CH})$ $120.0(\mathrm{CH}), 112.2(\mathrm{CH}), 70.1(\mathrm{C}), 28.1\left(\mathrm{CH}_{3}\right), 21.2\left(\mathrm{CH}_{3}\right)$.

\section{Enantioenriched (S)-1-(3-iodobenzofuran-2-yl)-2-(6-methoxynaphthalen-2-yl)propan-1-one (2p)}<smiles>COc1ccc2cc([C@@H](C)C(=O)c3oc4ccccc4c3I)ccc2c1</smiles>

Chemical Formula: $\mathrm{C}_{22} \mathrm{H}_{17} \mathrm{IO}_{3}$

Physical State: Yellow oil

Yield: $56 \%$

HRMS calcd. for $\mathrm{C}_{22} \mathrm{H}_{17} \mathrm{NaO}_{3}(\mathrm{M}+\mathrm{Na}): 479.0115$

HRMS (ESI) found: 479.0115

${ }^{1} \mathrm{H}$ NMR (300 MHz, $\left.\mathrm{CD}_{2} \mathrm{Cl}_{2}\right): \delta(\mathrm{ppm}) 7.75(\mathrm{~s}, 1 \mathrm{H}), 7.70(\mathrm{~d}, J=9.1 \mathrm{~Hz}, 2 \mathrm{H}), 7.52-7.50(\mathrm{~m}, 4 \mathrm{H}), 7.37-7.31$ (ddd, $J=7.8,5.5,2.7 \mathrm{~Hz}$ $1 \mathrm{H}), 7.12-7.09(\mathrm{~m}, 2 \mathrm{H}), 5.06(\mathrm{q}, J=7.0 \mathrm{~Hz}, 1 \mathrm{H}), 3.87(\mathrm{~s}, 3 \mathrm{H}), 1.62(\mathrm{~d}, J=7.0 \mathrm{~Hz}, 3 \mathrm{H})$.

${ }^{13} \mathrm{C}$ NMR (100 MHz, $\mathbf{C D}_{2} \mathrm{Cl}_{2}$ ): $\delta(\mathrm{ppm}) 192.2$ (C), 158.3 (C), $154.8(\mathrm{C}), 149.5(\mathrm{C}), 135.8(\mathrm{C}), 134.2(\mathrm{C}), 132.1(\mathrm{C}), 129.7(2 \mathrm{CH}), 129.6$ $(\mathrm{C}), 127.7(\mathrm{CH}), 127.5(\mathrm{CH}), 127.3(\mathrm{CH}), 124.9(\mathrm{CH}), 124.2(\mathrm{CH}), 119.4(\mathrm{CH}), 112.8(\mathrm{CH}), 106.0(\mathrm{CH}), 72.3(\mathrm{C}), 55.8\left(\mathrm{CH}_{3}\right), 48.6$ $(\mathrm{CH}), 18.4\left(\mathrm{CH}_{3}\right)$

er: 87:13 determined by HPLC (for analytical conditions and chromatograms see HPLC data of final products 
5. Copies of spectra

5.1. Spectra for starting materials (1)

Ia ${ }^{1} \mathrm{H}$ NMR spectra $\left(\mathrm{CD}_{2} \mathrm{Cl}_{2}\right)$

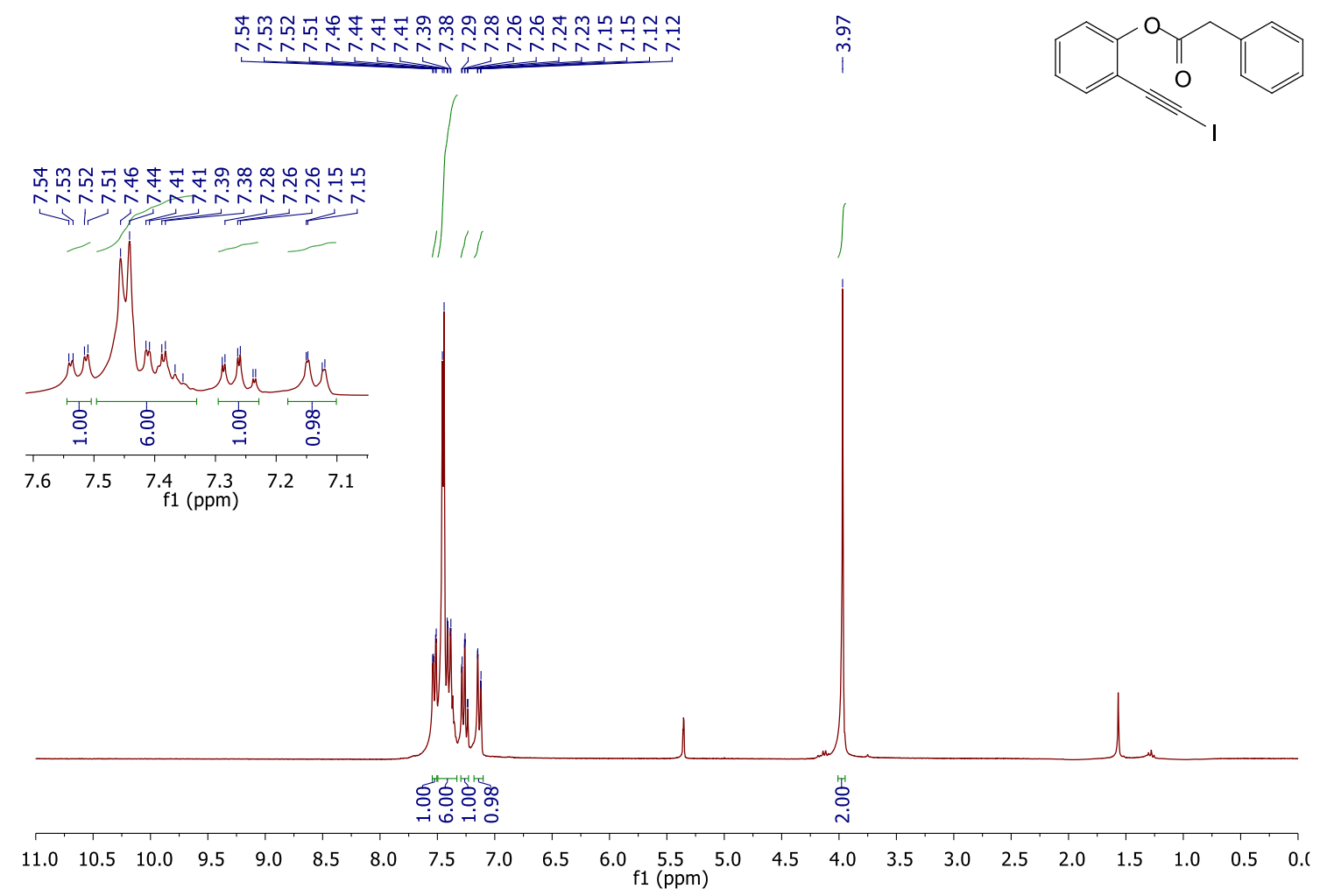

Ia ${ }^{13} \mathrm{C}$ NMR spectra $\left(\mathrm{CD}_{2} \mathrm{Cl}_{2}\right)$
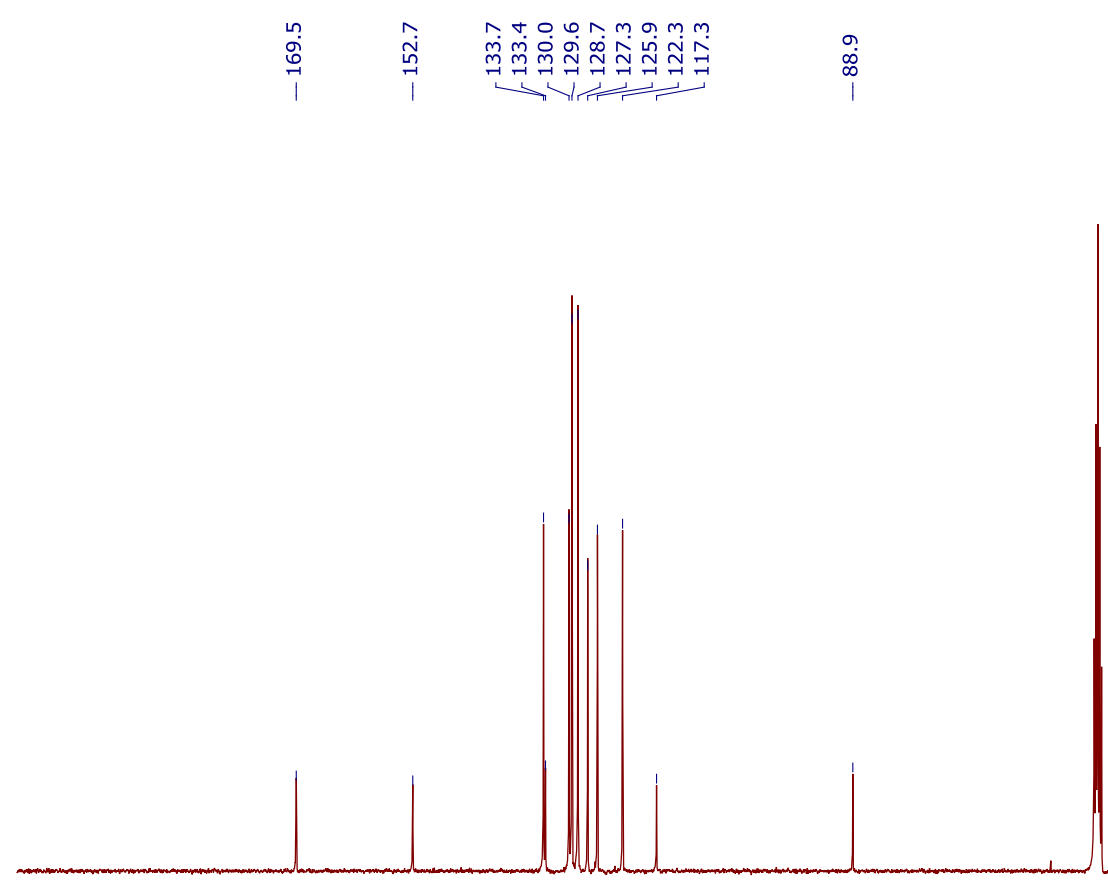

$\underset{\substack{a \\ \infty \\ \infty \\ 1}}{\substack{0 \\ 1}}$

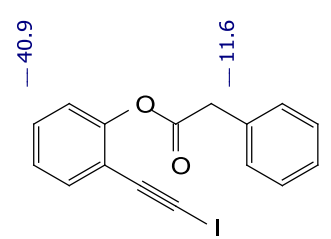

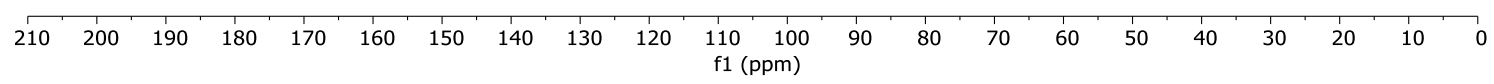

31 


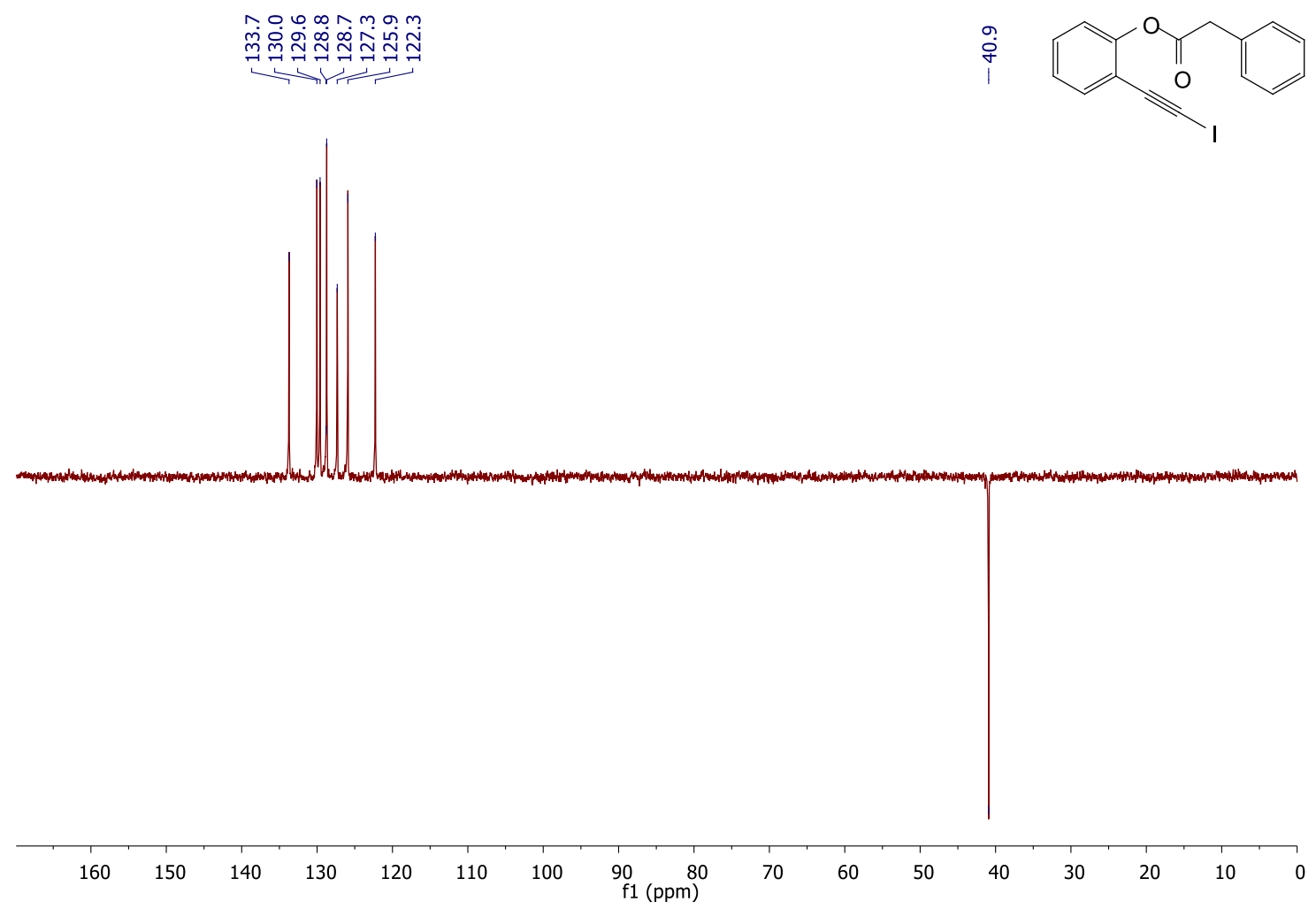

1b ${ }^{1} \mathrm{H}$ NMR spectra $\left(\mathrm{CD}_{2} \mathrm{Cl}_{2}\right)$

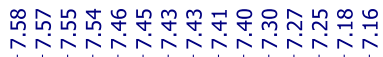

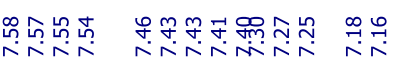

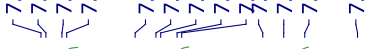
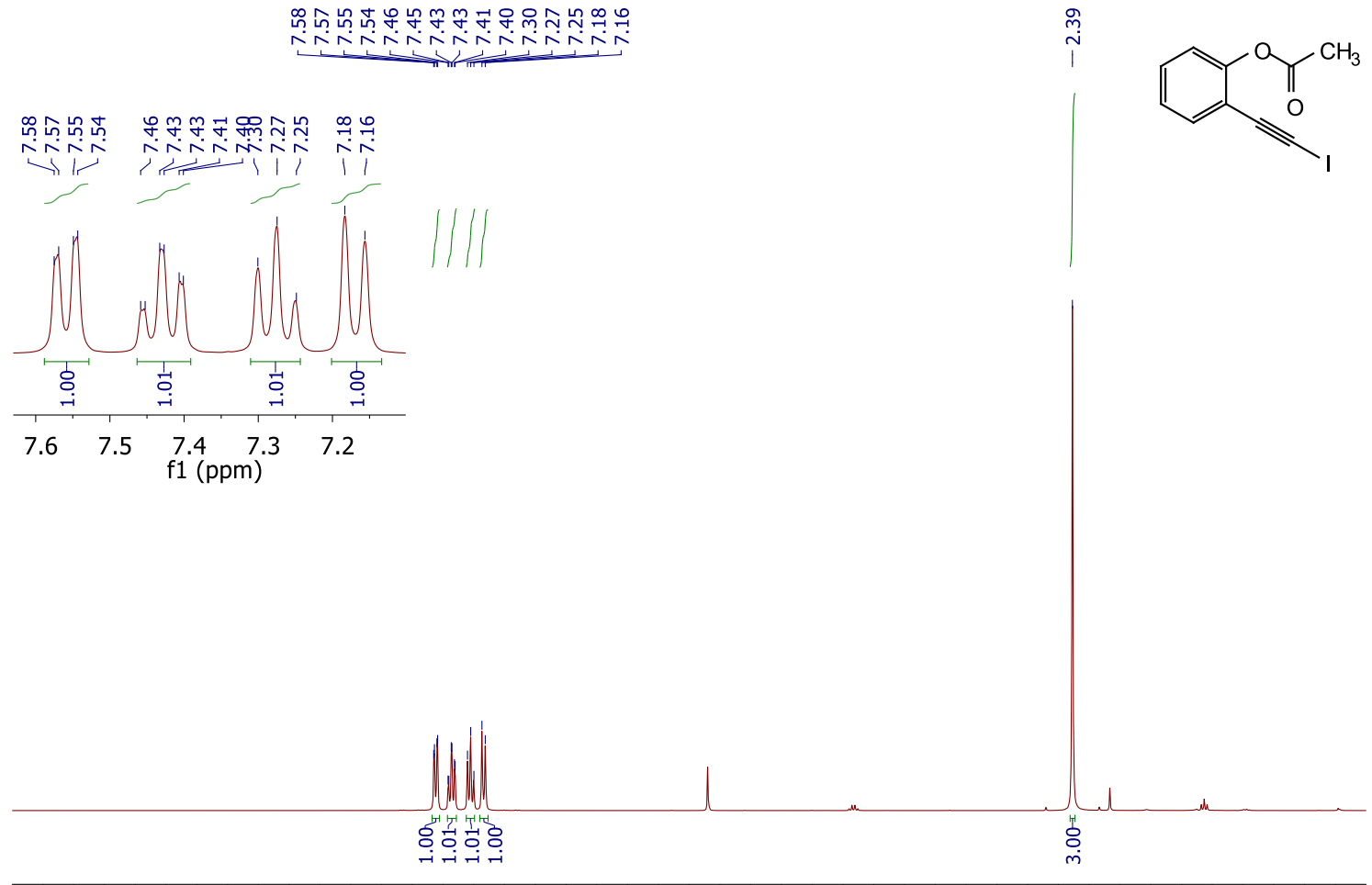

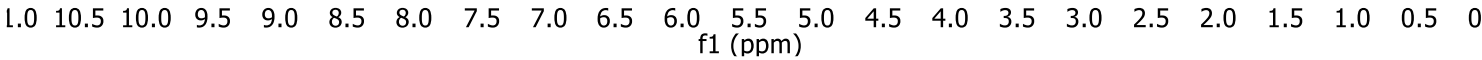


1b ${ }^{13} \mathrm{C}$ NMR spectra $\left(\mathrm{CD}_{2} \mathrm{Cl}_{2}\right)$
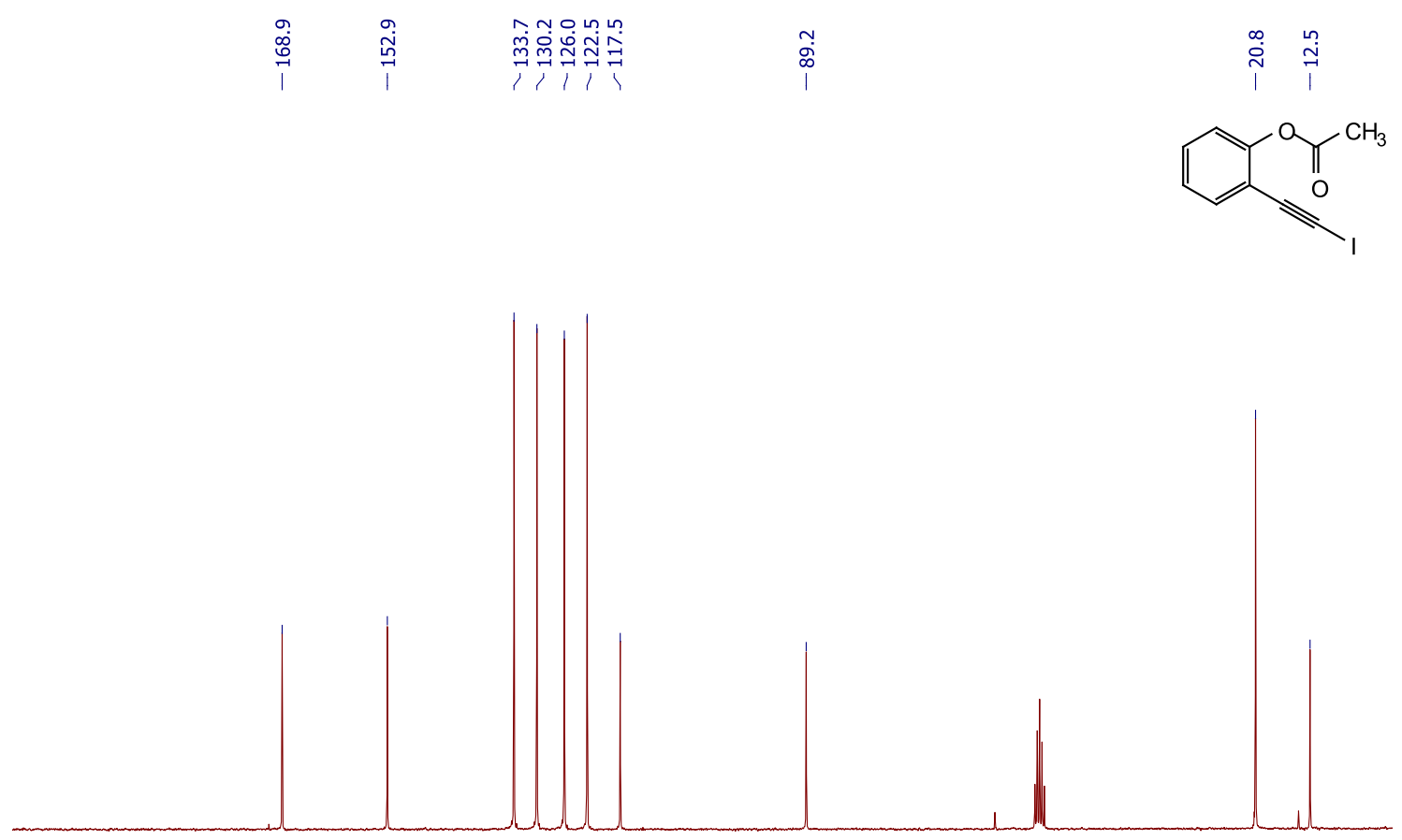

$\begin{array}{lllllllllllllllllllll}10 & 200 & 190 & 180 & 170 & 160 & 150 & 140 & 130 & 120 & \begin{array}{c}110 \\ \mathrm{f} 1(\mathrm{ppm})\end{array} & 90 & 80 & 70 & 60 & 50 & 40 & 30 & 20 & 10 & 1\end{array}$

1b DEPT NMR spectra $\left(\mathrm{CD}_{2} \mathrm{Cl}_{2}\right)$

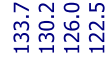

$\stackrel{\infty}{\stackrel{i}{i}}$

र्र人
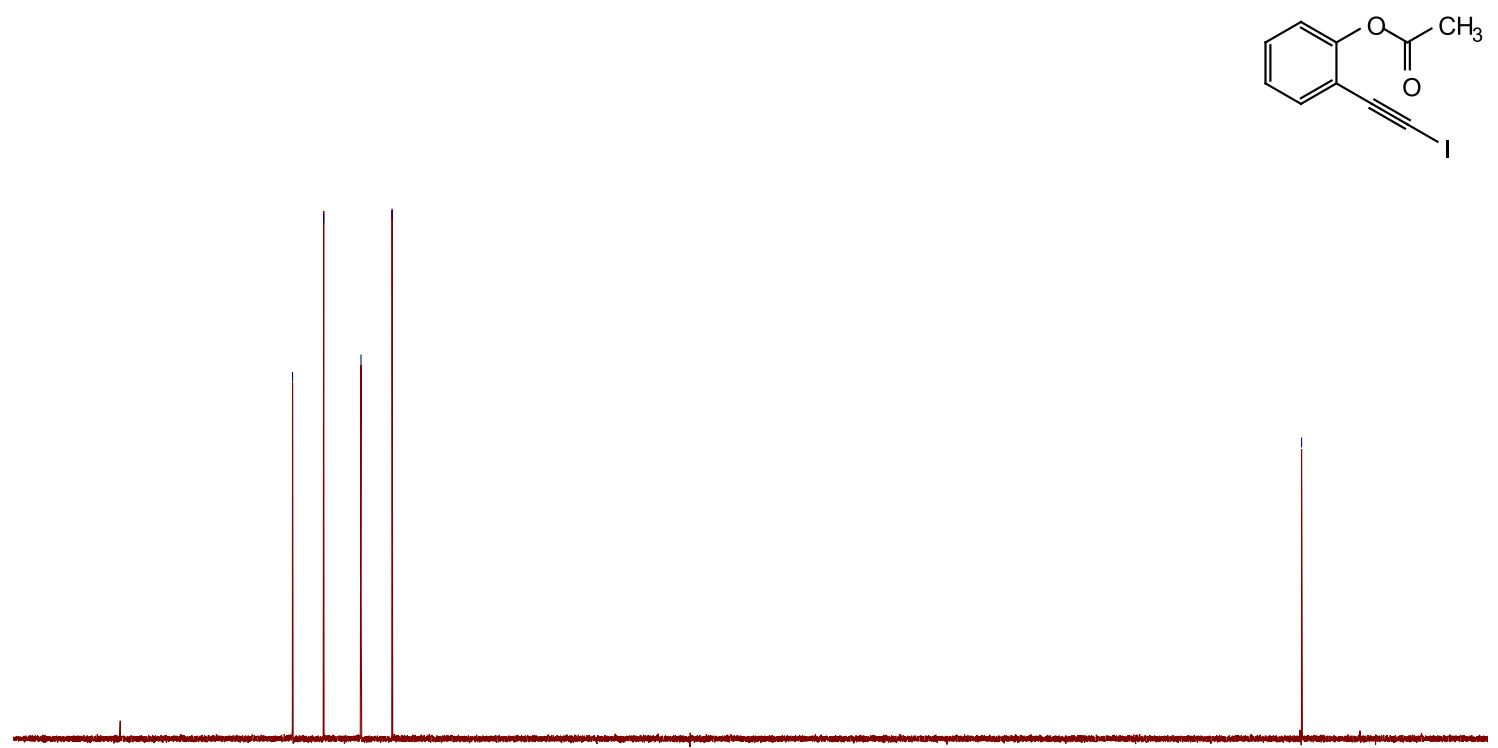

$\begin{array}{lllllllllllllll}160 & 150 & 140 & 130 & 120 & 110 & 100 & 90 \begin{array}{c}80 \\ \mathrm{f} 1(\mathrm{ppm})\end{array} & 70 & 60 & 50 & 40 & 30 & 20 & 10\end{array}$ 


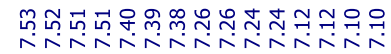

倠
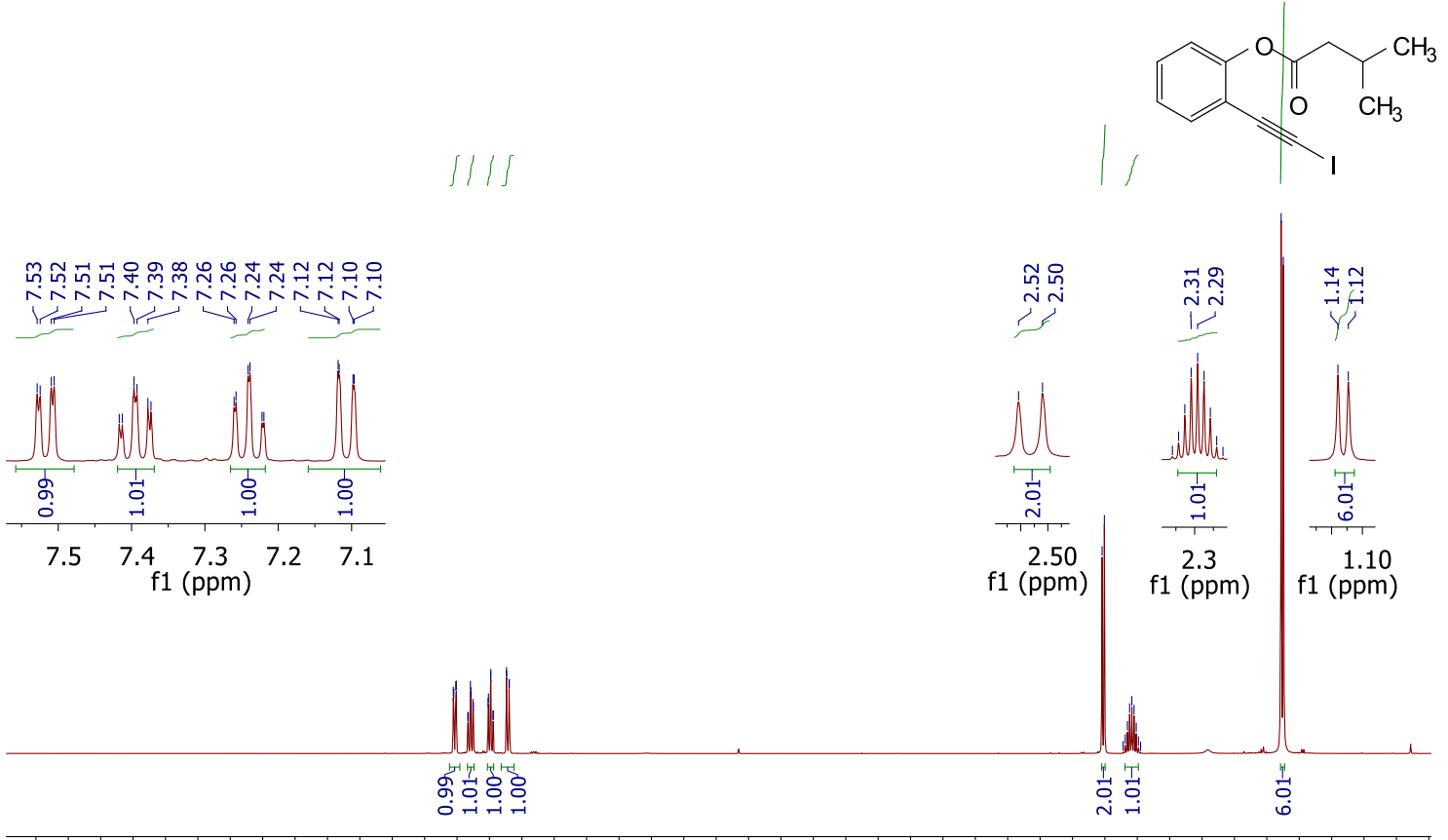

$\begin{array}{llllllllllllllllllllll}10.5 & 10.0 & 9.5 & 9.0 & 8.5 & 8.0 & 7.5 & 7.0 & 6.5 & 6.0 & \underset{f 1}{(\mathrm{ppm})} \begin{array}{l}5.5 \\ 5.0\end{array} & 4.5 & 4.0 & 3.5 & 3.0 & 2.5 & 2.0 & 1.5 & 1.0 & 0.5 & 0.1\end{array}$

1C ${ }^{13} \mathrm{C}$ NMR spectra $\left(\mathrm{CD}_{2} \mathrm{Cl}_{2}\right)$

吾 $\quad$ in
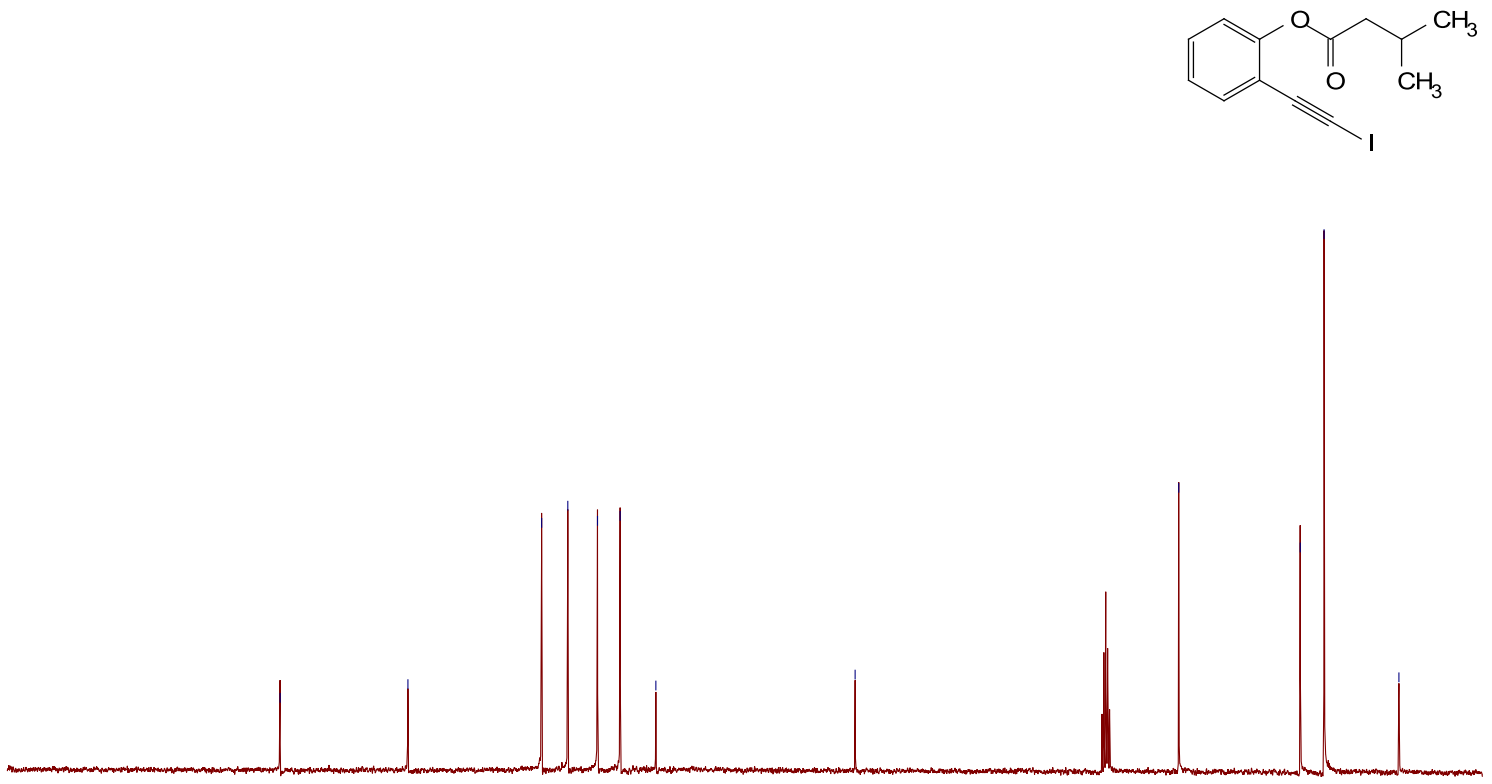

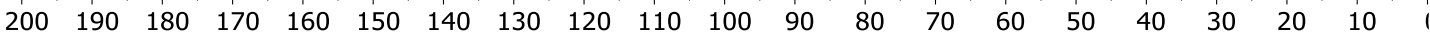
f1 (ppm) 


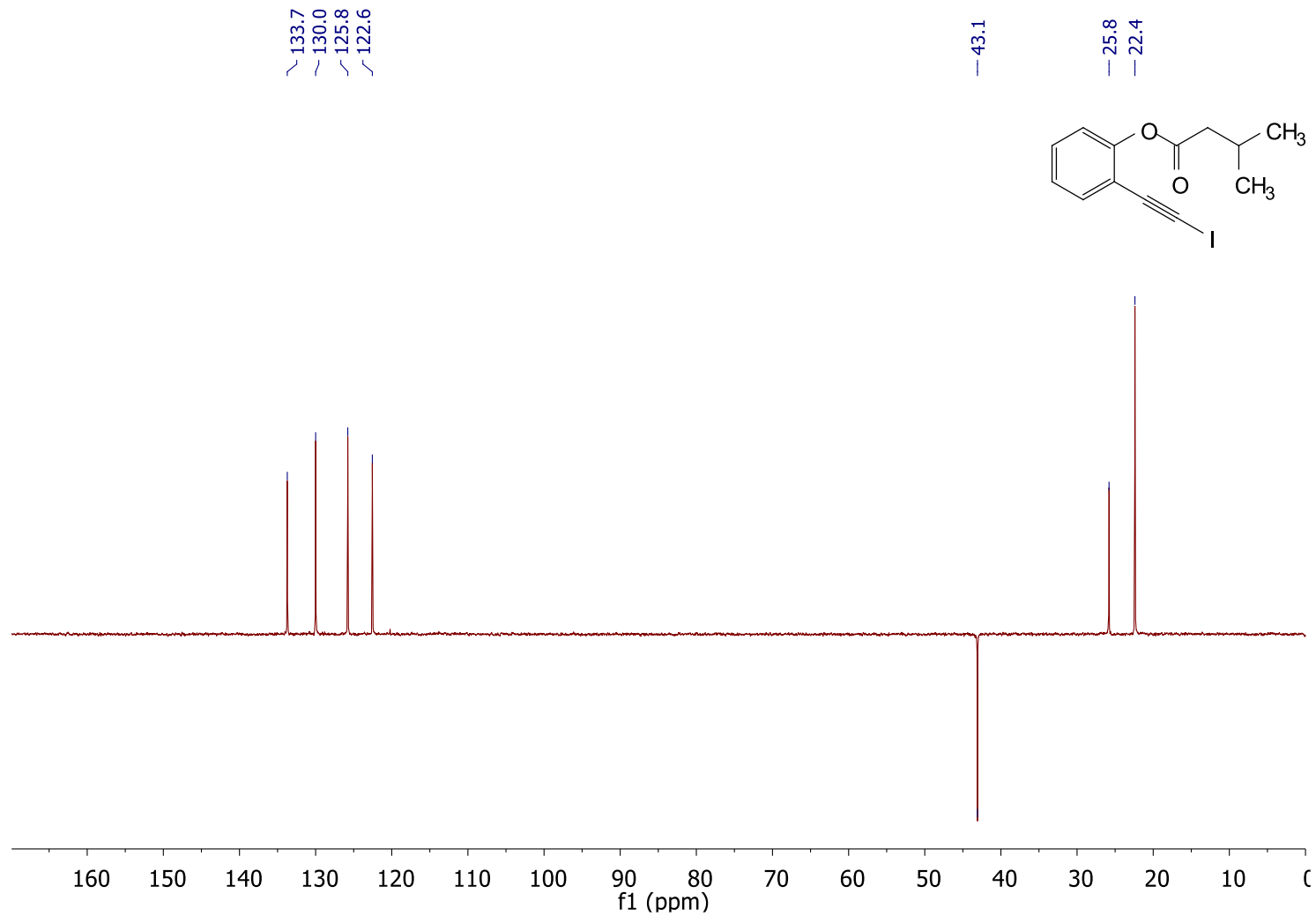

1d ${ }^{1} \mathrm{H}$ NMR spectra $\left(\mathrm{CD}_{2} \mathrm{Cl}_{2}\right)$

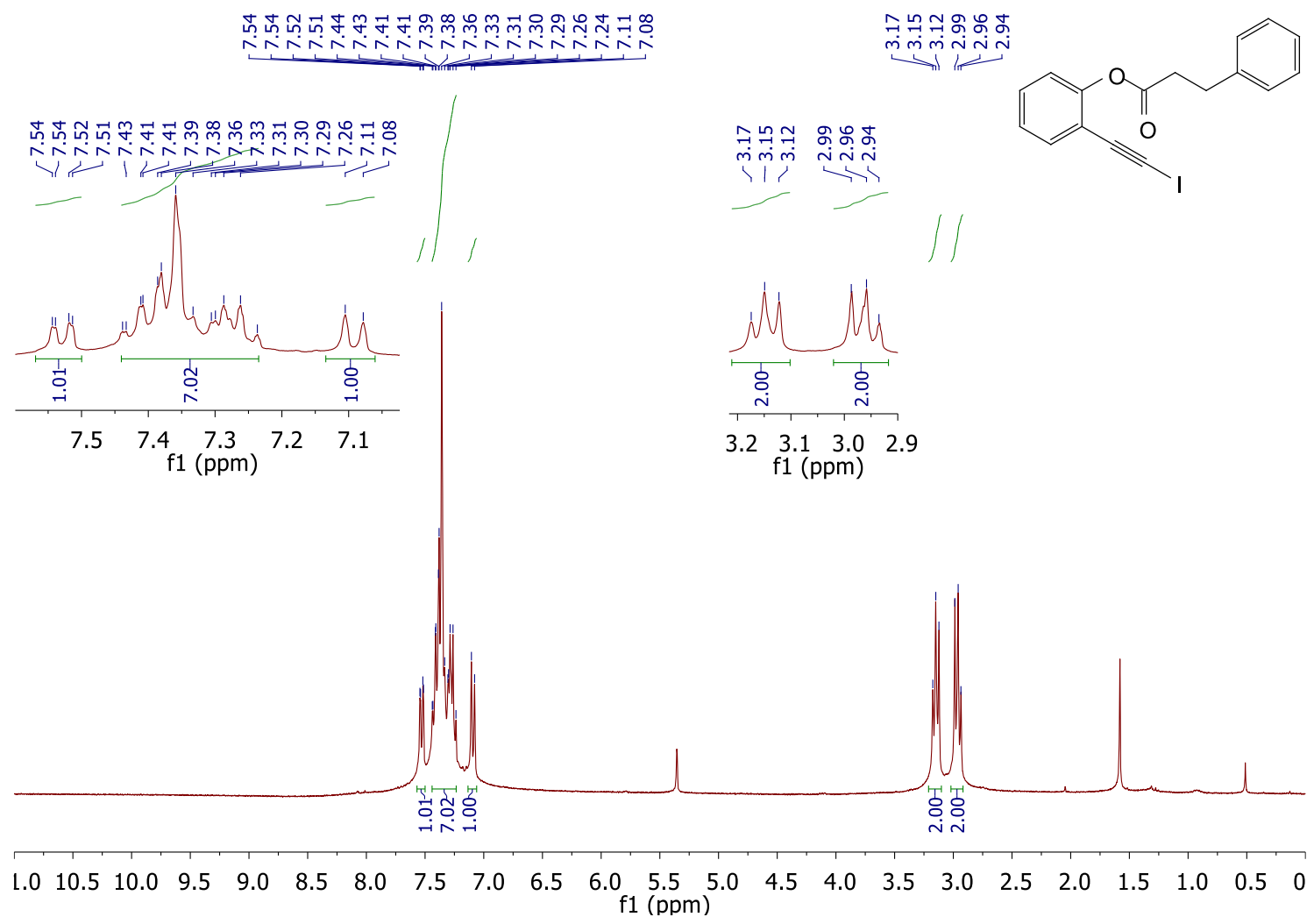


1d ${ }^{13} \mathrm{C}$ NMR spectra $\left(\mathrm{CD}_{2} \mathrm{Cl}_{2}\right)$

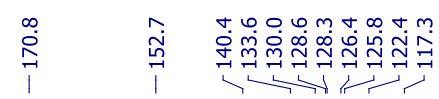

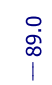

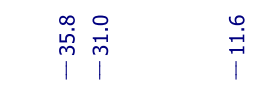

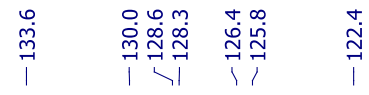

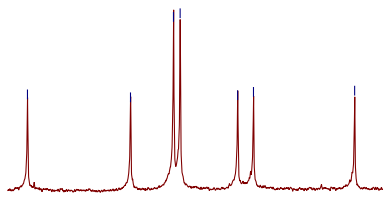

$\begin{array}{lllllll}34 & 132 & 130 & 128 & 126 & 124 & 122\end{array}$

f1 (ppm)
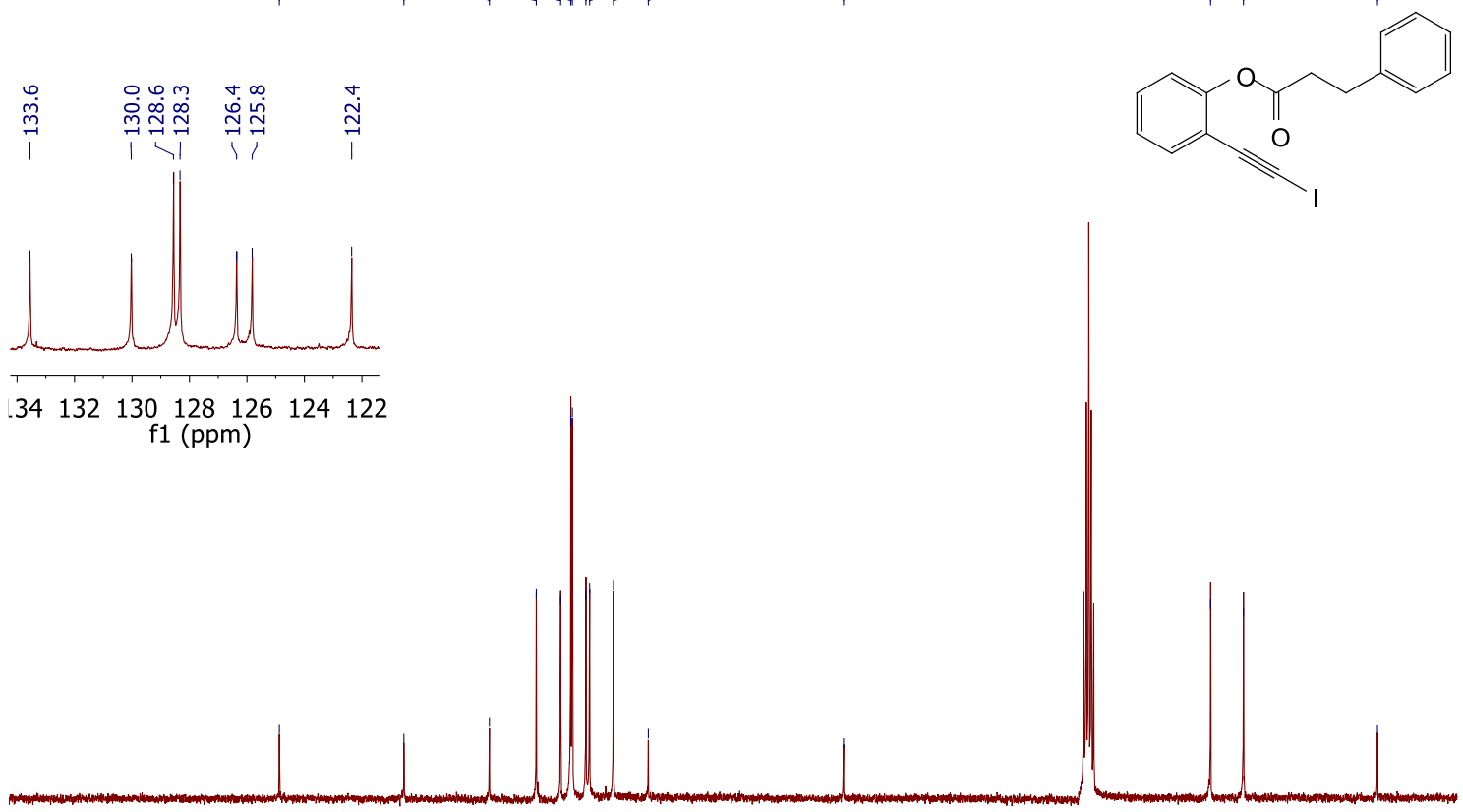

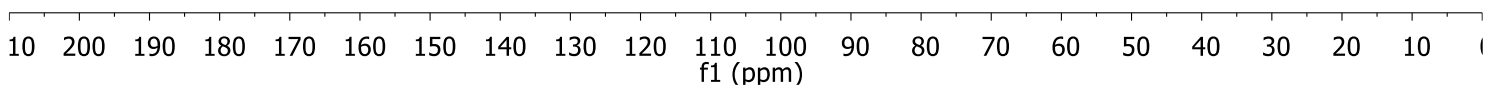

1d DEPT NMR spectra $\left(\mathrm{CD}_{2} \mathrm{Cl}_{2}\right)$

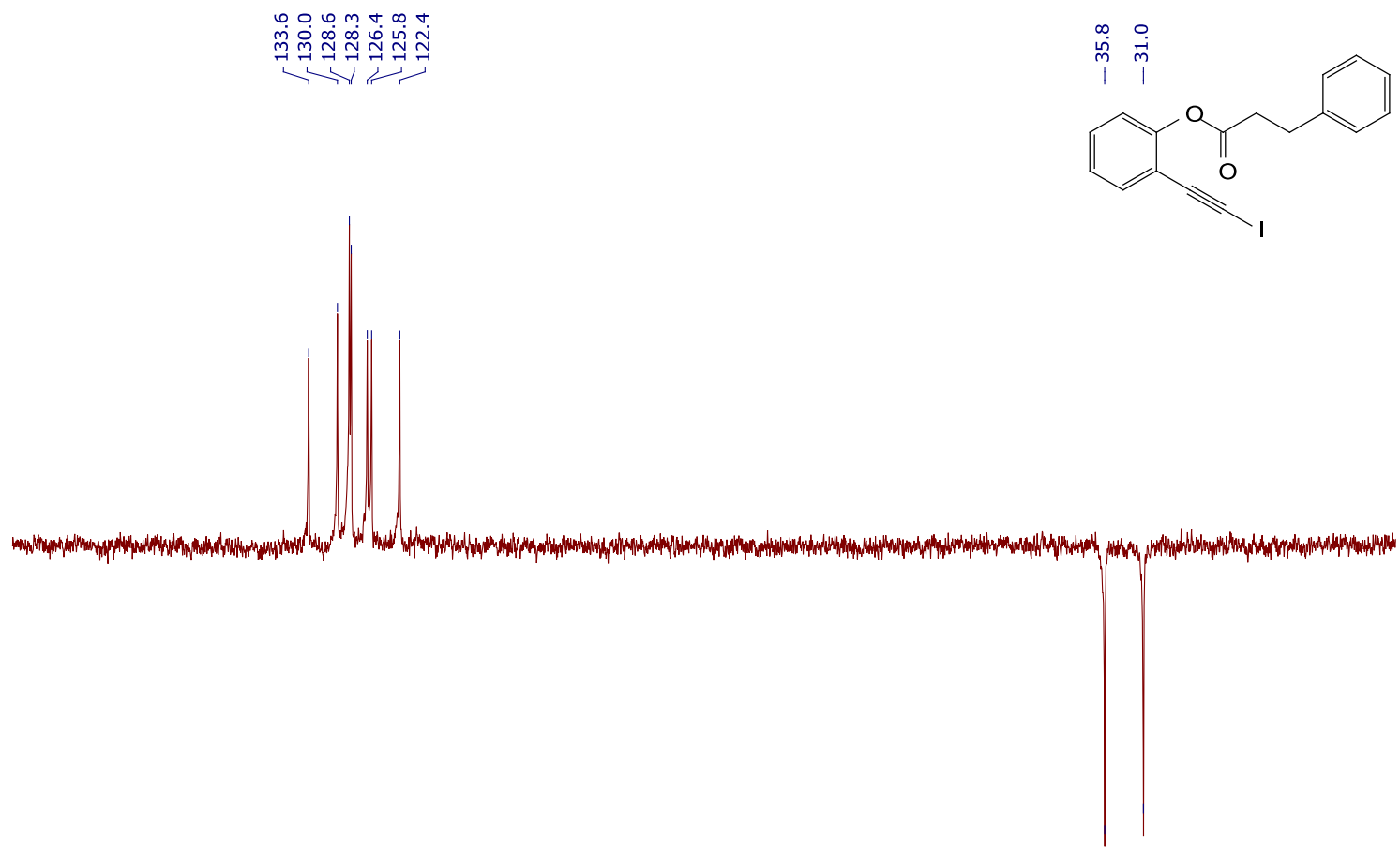

\begin{tabular}{lllllllllllllllll}
\hline 70 & 160 & 150 & 140 & 130 & 120 & 110 & 100 & $\begin{array}{c}90 \\
\mathrm{f} 1(\mathrm{ppm})\end{array}$ & 70 & 60 & 50 & 40 & 30 & 20 & 10 & 1
\end{tabular} 
1e ${ }^{1} \mathrm{H}$ NMR spectra $\left(\mathrm{CD}_{2} \mathrm{Cl}_{2}\right)$

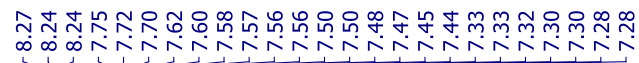
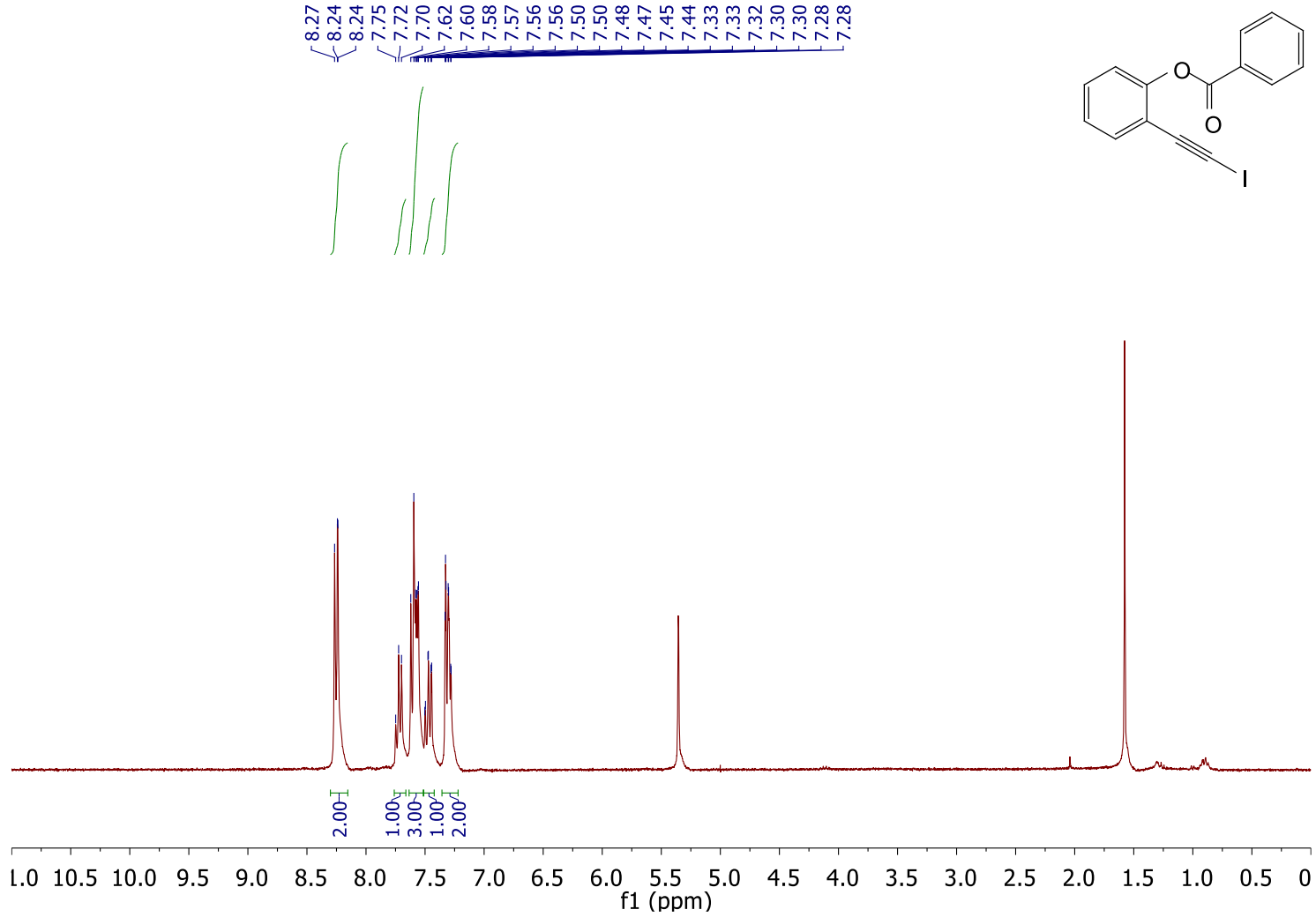

1e ${ }^{13} \mathrm{C}$ NMR spectra $\left(\mathrm{CD}_{2} \mathrm{Cl}_{2}\right)$
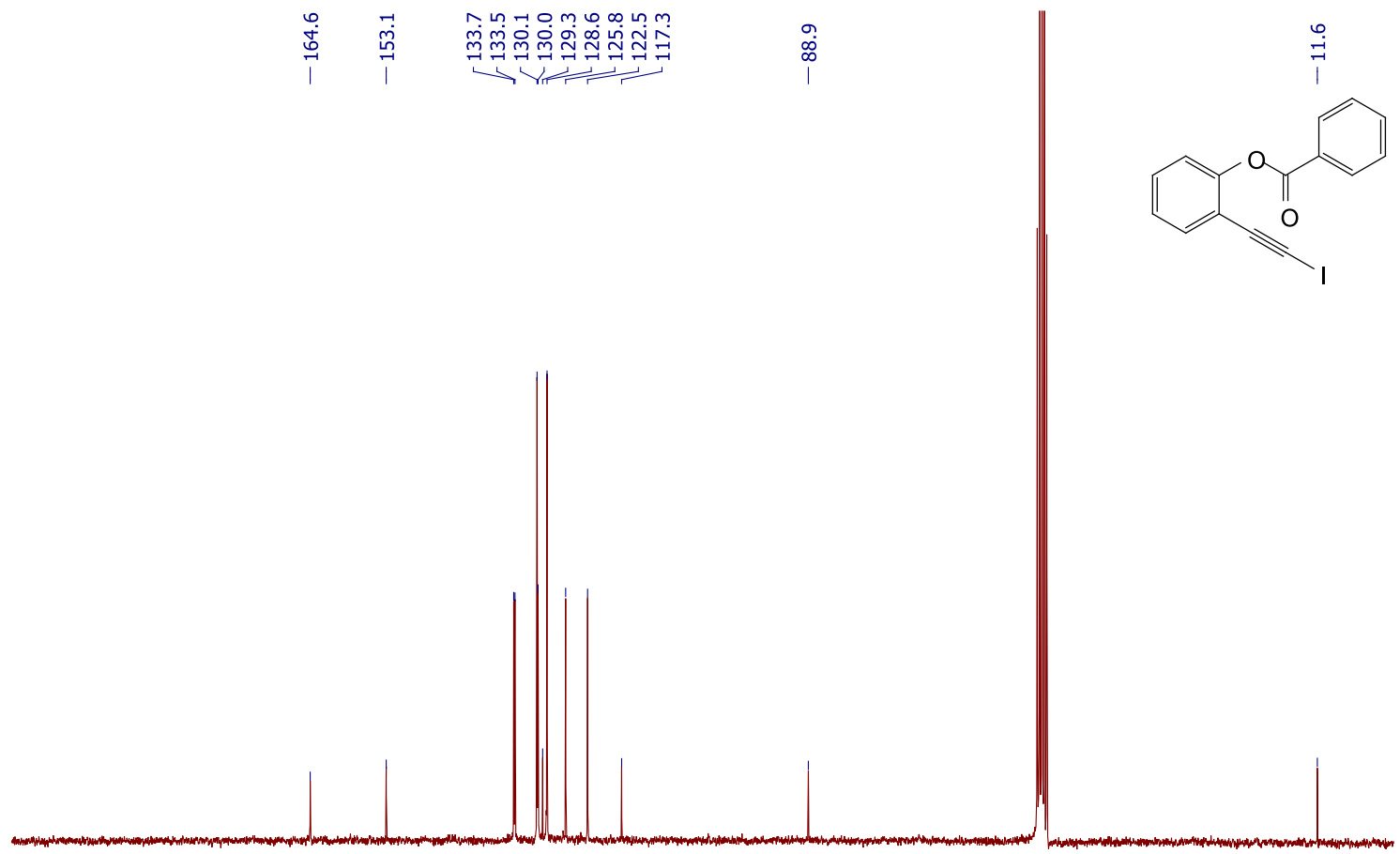

$\begin{array}{llllllllllllllllllllll}10 & 200 & 190 & 180 & 170 & 160 & 150 & 140 & 130 & 120 & \begin{array}{c}110 \\ \mathrm{f} 1(\mathrm{ppm})\end{array} & 90 & 80 & 70 & 60 & 50 & 40 & 30 & 20 & 10 & 1\end{array}$ 


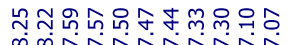

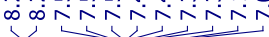
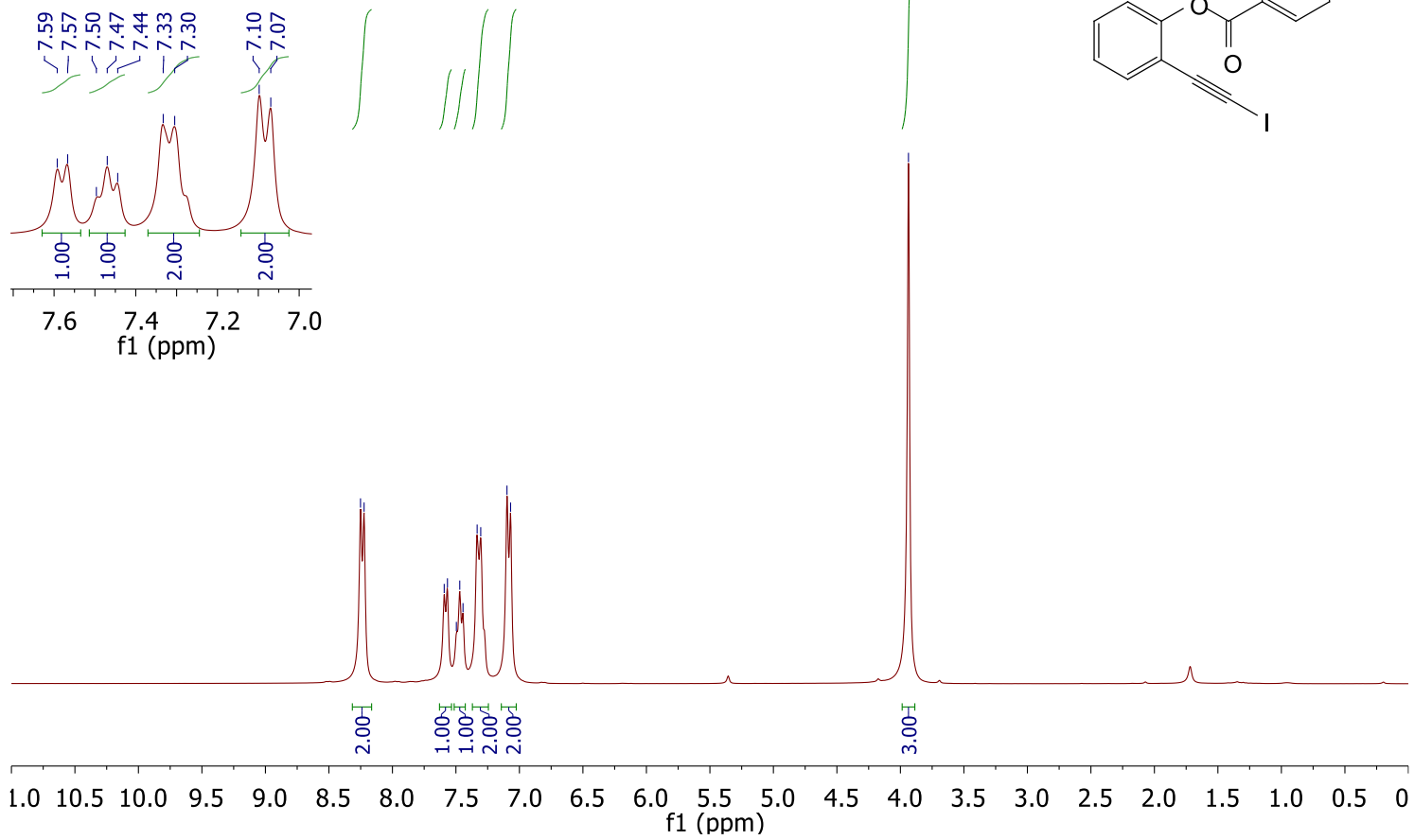

1f ${ }^{13} \mathrm{C}$ NMR spectra $\left(\mathrm{CD}_{2} \mathrm{Cl}_{2}\right)$



妾

f1 (ppm)

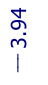

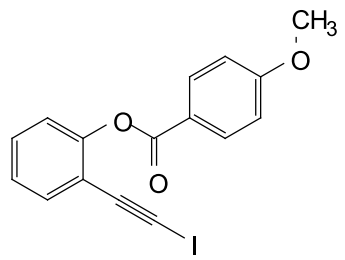

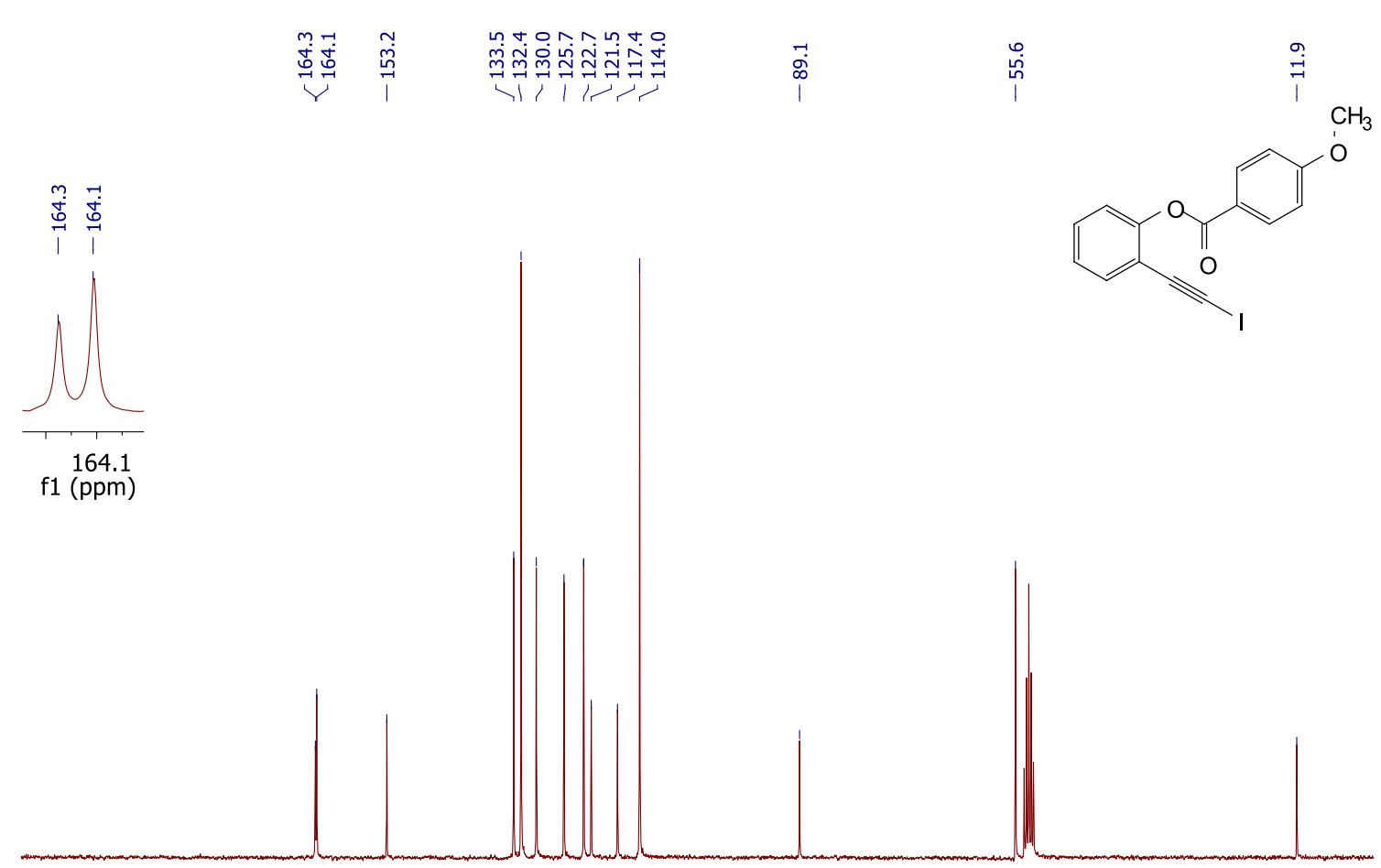

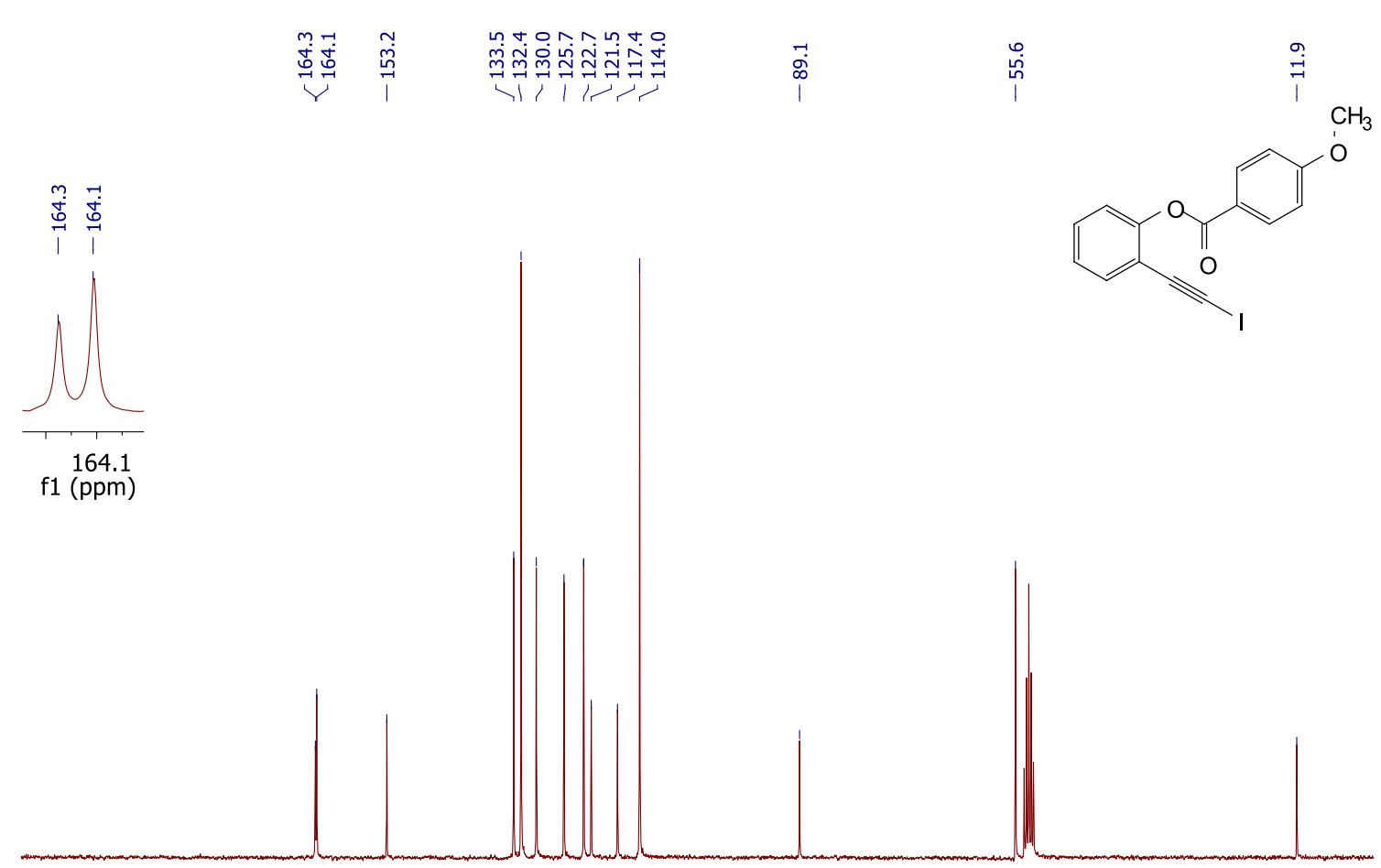

$\begin{array}{llllllllllllllllllllll}10 & 200 & 190 & 180 & 170 & 160 & 150 & 140 & 130 & 120 & \begin{array}{c}110 \\ \mathrm{f} 1(\mathrm{ppm})\end{array} & 90 & 80 & 70 & 60 & 50 & 40 & 30 & 20 & 10 & (\end{array}$ 


\section{$1 \mathrm{I}{ }^{1} \mathrm{H}$ NMR spectra $\left(\mathrm{CD}_{2} \mathrm{Cl}_{2}\right)$}

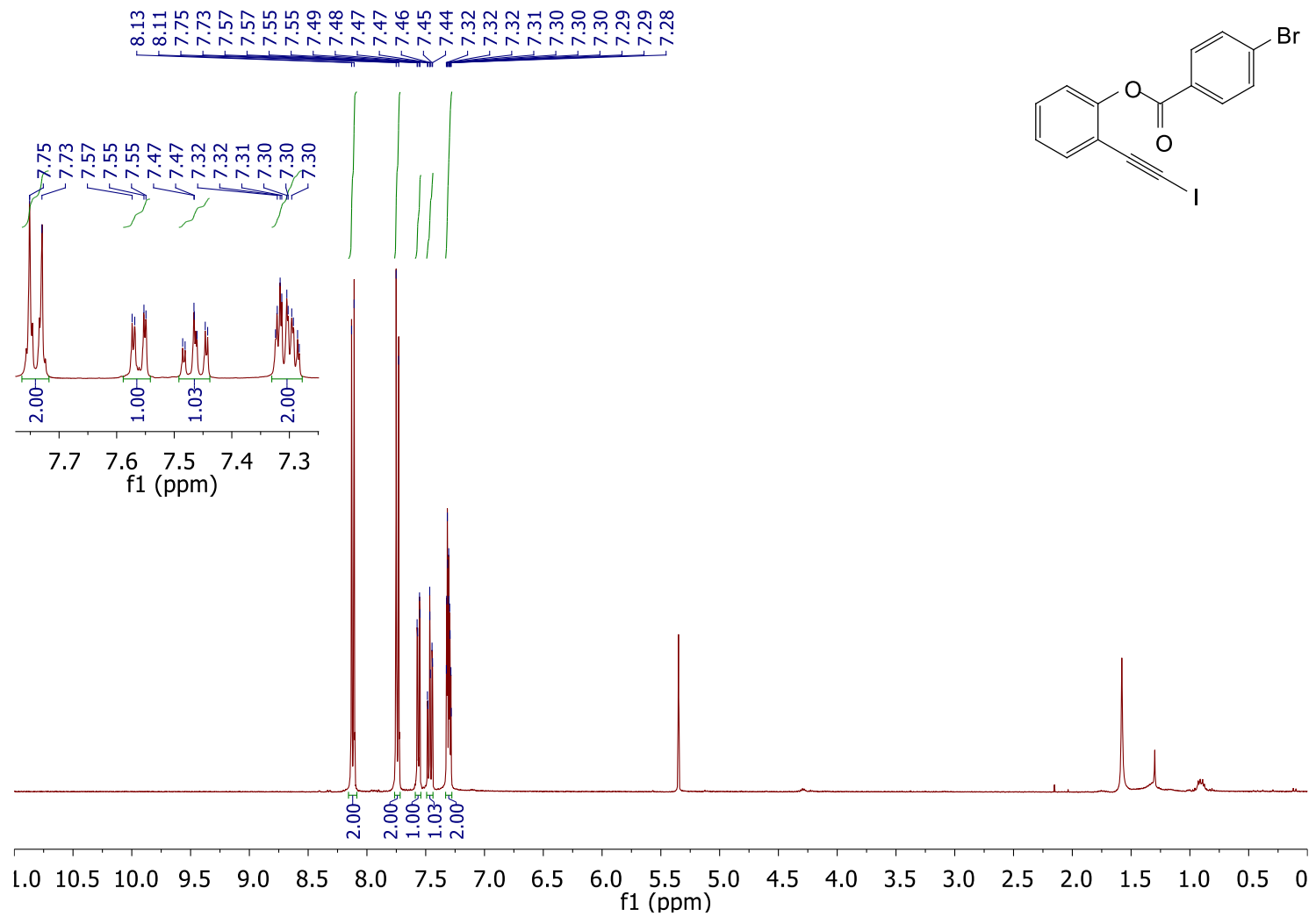

$1 \mathrm{~g}{ }^{13} \mathrm{C}$ NMR spectra $\left(\mathrm{CD}_{2} \mathrm{Cl}_{2}\right)$
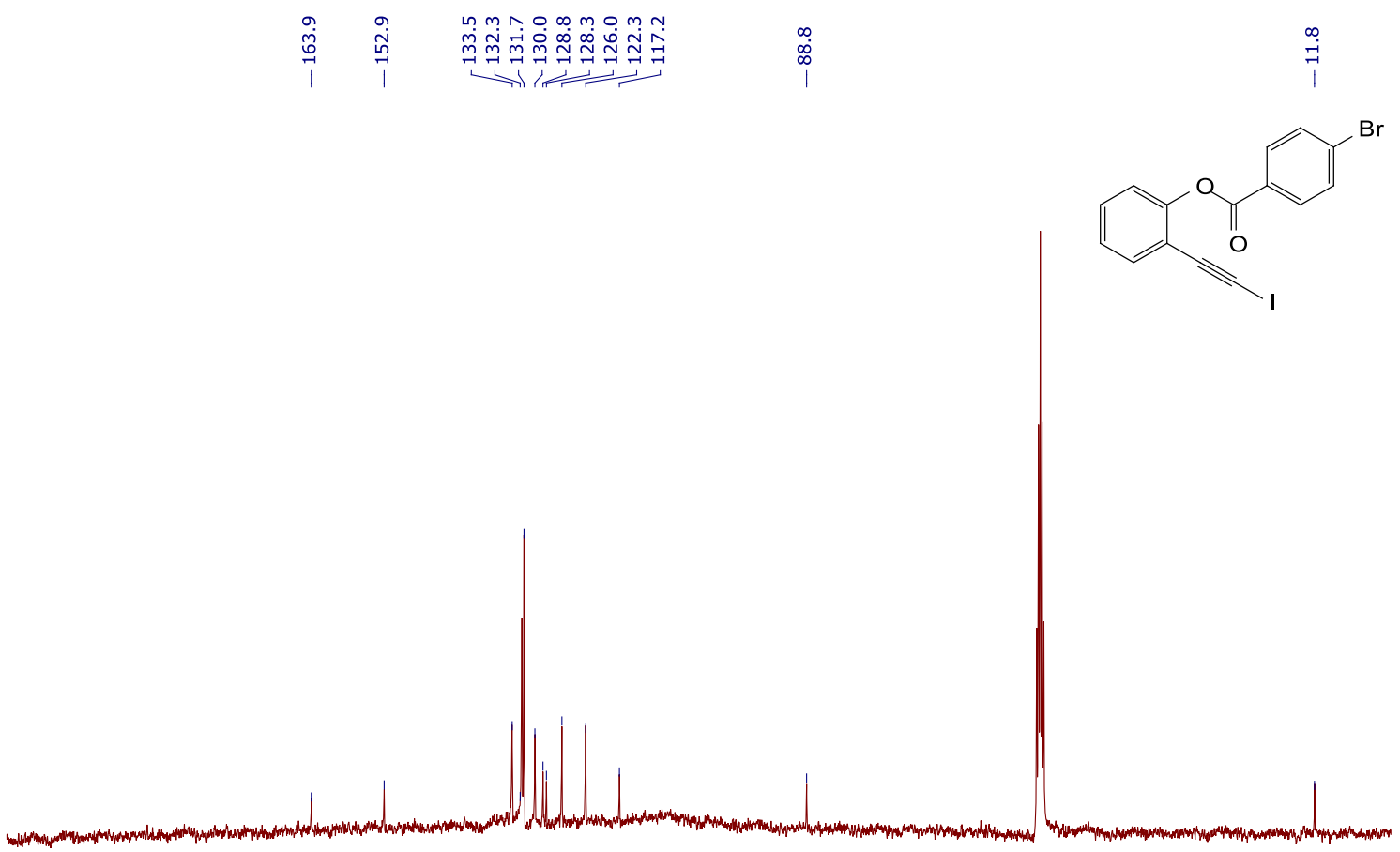

$\begin{array}{llllllllllllllllllllllll}10 & 200 & 190 & 180 & 170 & 160 & 150 & 140 & 130 & 120 & 110 & 100 & 90 & 80 & 70 & 60 & 50 & 40 & 30 & 20 & 10 & 10\end{array}$ f1 (ppm) 
$1 \mathrm{DEPT}$ NMR spectra $\left(\mathrm{CD}_{2} \mathrm{Cl}_{2}\right)$
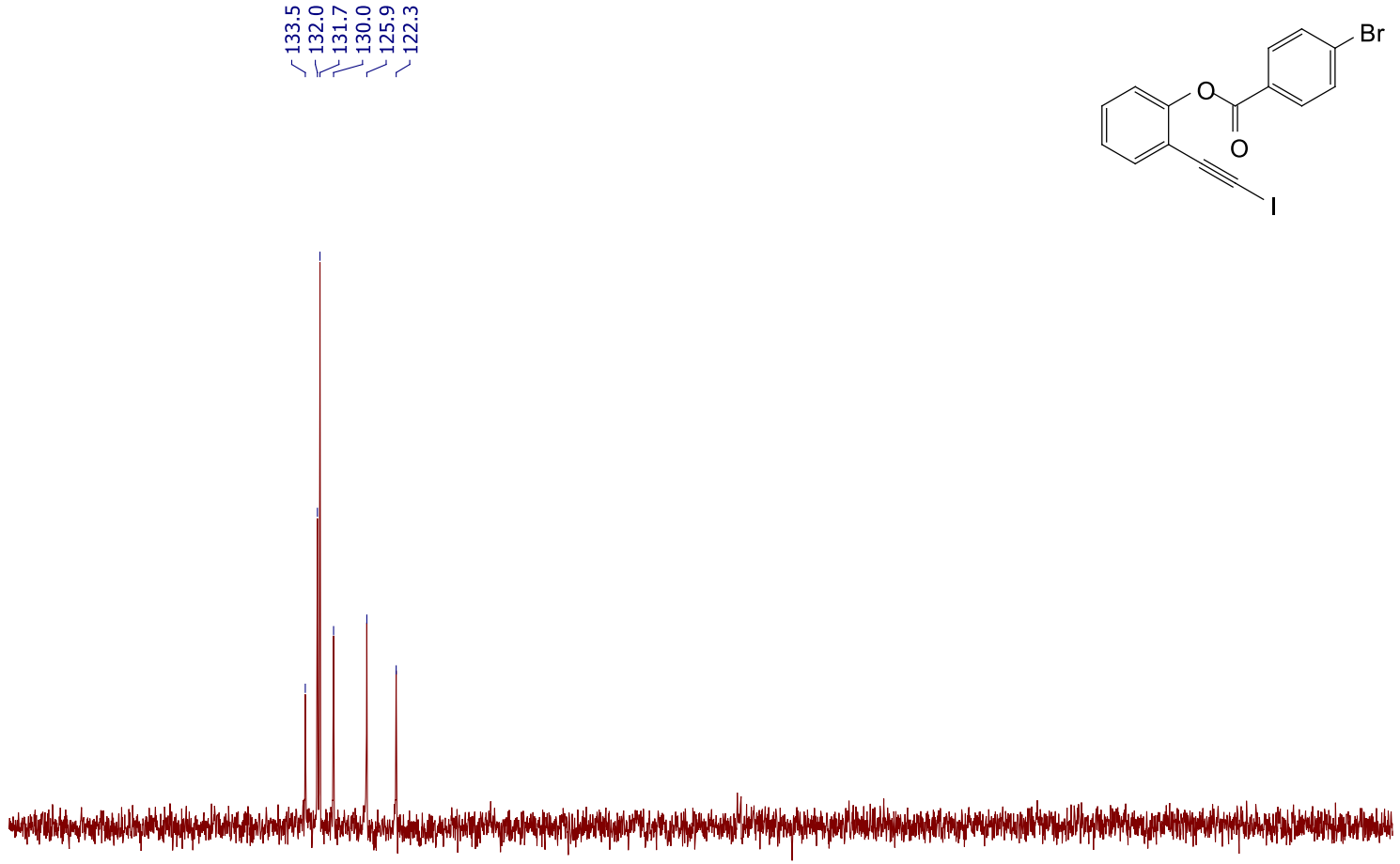

$\begin{array}{llllllllllllllll}160 & 150 & 140 & 130 & 120 & 110 & 100 & \begin{array}{c}90 \\ \mathrm{f} 1(\mathrm{ppm})\end{array} & \begin{array}{l}80 \\ (\mathrm{pm})\end{array} & 60 & 50 & 40 & 30 & 20 & 10 & 1\end{array}$

1h ${ }^{1} \mathrm{H}$ NMR spectra $\left(\mathrm{CD}_{2} \mathrm{Cl}_{2}\right)$

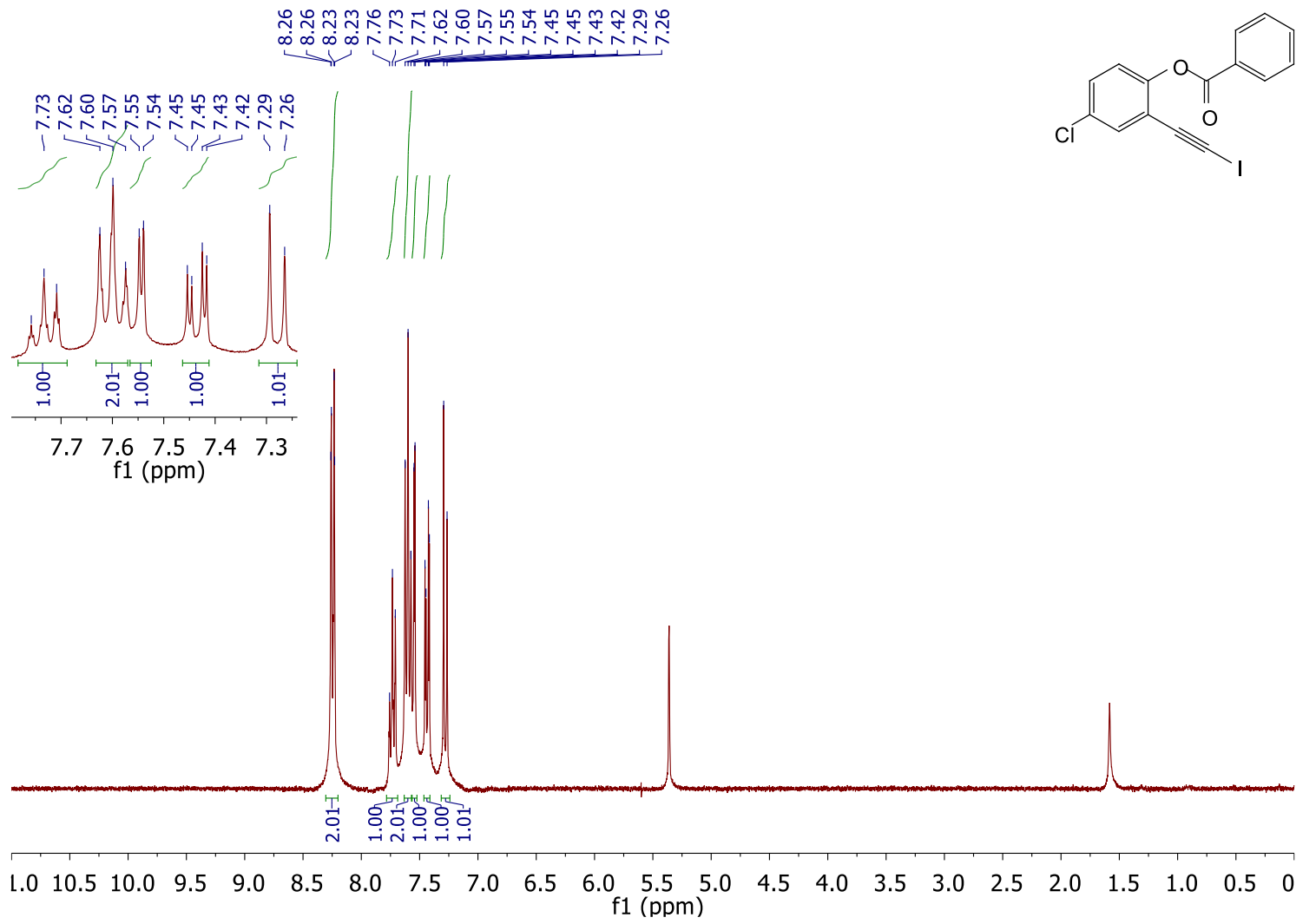


1h ${ }^{13} \mathrm{C}$ NMR spectra $\left(\mathrm{CD}_{2} \mathrm{Cl}_{2}\right)$

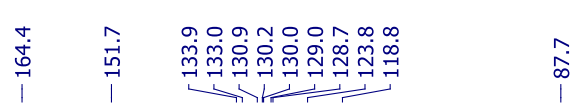

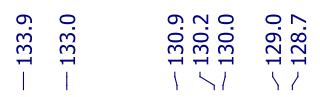

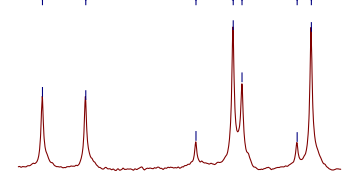

134133132131130129

f1 (ppm)

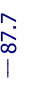

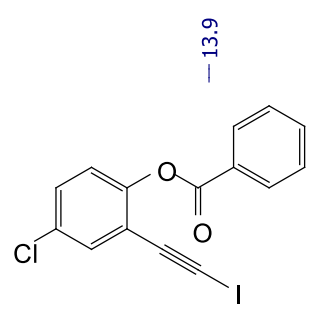

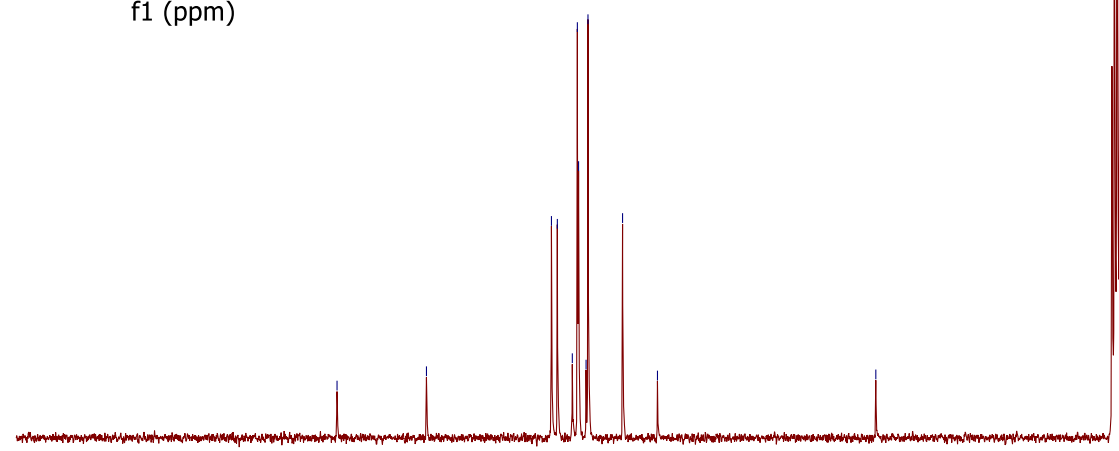

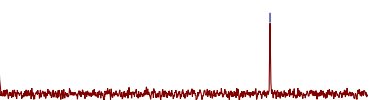

10

$200 \quad 190$

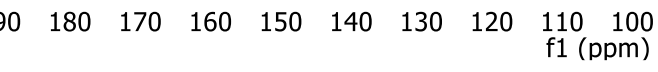

$\begin{array}{llll}80 & 70 & 60\end{array}$

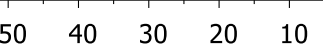

1h DEPT NMR spectra $\left(\mathrm{CD}_{2} \mathrm{Cl}_{2}\right)$

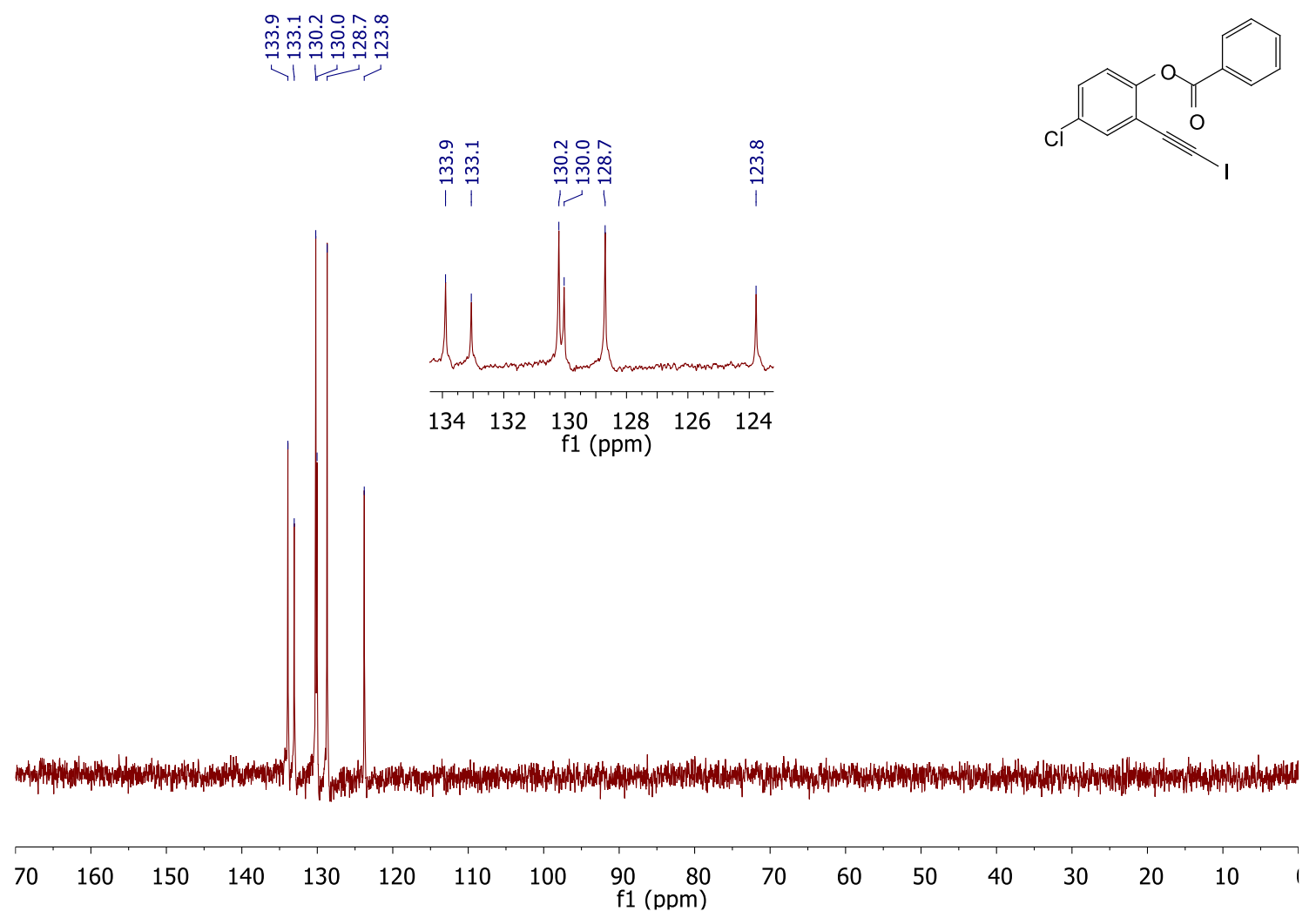


1i ${ }^{1} \mathrm{H}$ NMR spectra $\left(\mathrm{CD}_{2} \mathrm{Cl}_{2}\right)$

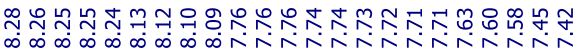

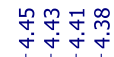

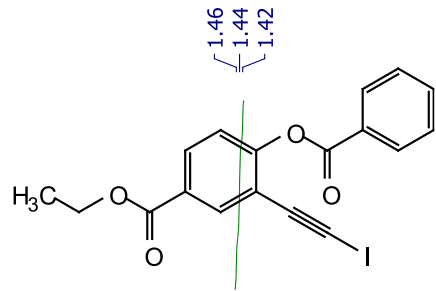

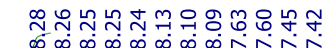

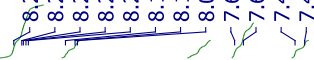
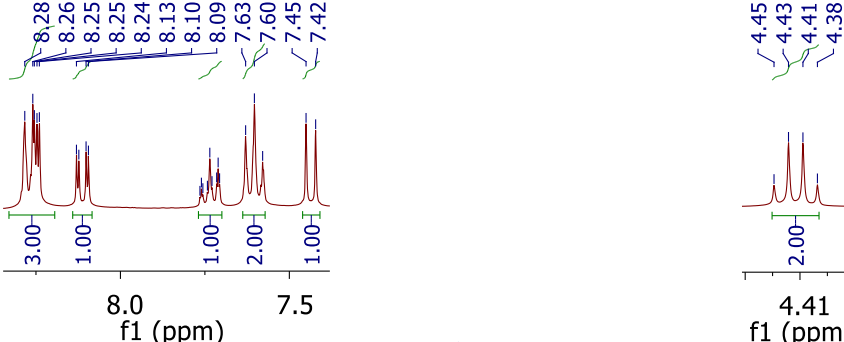

itis
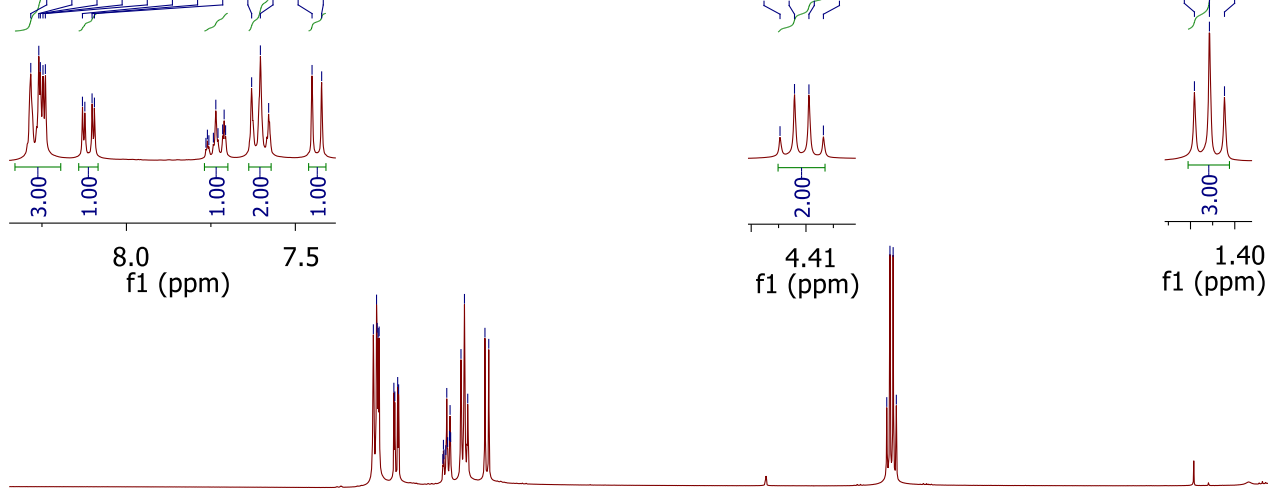

f1 (ppm)

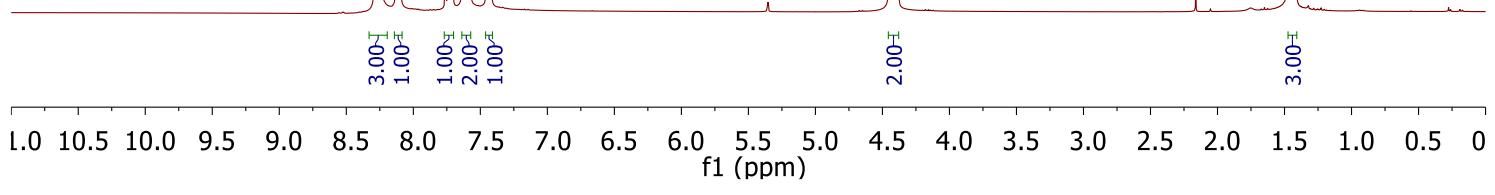

1i ${ }^{13} \mathrm{C}$ NMR spectra $\left(\mathrm{CD}_{2} \mathrm{Cl}_{2}\right)$

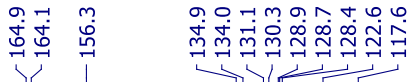

$\underset{\infty}{\infty}$

$\stackrel{1}{i}$

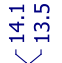

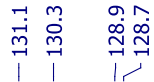

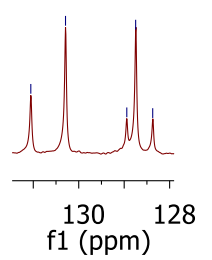<smiles>CCOC(=O)c1ccc(OC(=O)C2=CCCCC2)c(C#CI)c1</smiles>

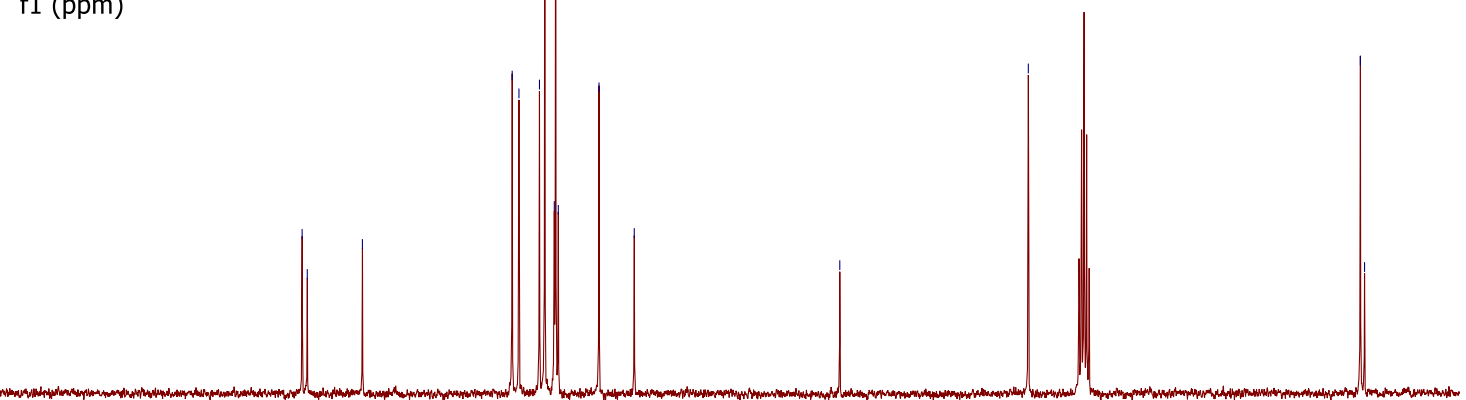

$\begin{array}{llllllllllllllllllllll}10 & 200 & 190 & 180 & 170 & 160 & 150 & 140 & 130 & 120 & \begin{array}{l}110 \\ \mathrm{f} 1(\mathrm{ppm})\end{array} & 90 & 80 & 70 & 60 & 50 & 40 & 30 & 20 & 10 & 10\end{array}$ 
1i DEPT NMR spectra $\left(\mathrm{CD}_{2} \mathrm{Cl}_{2}\right)$

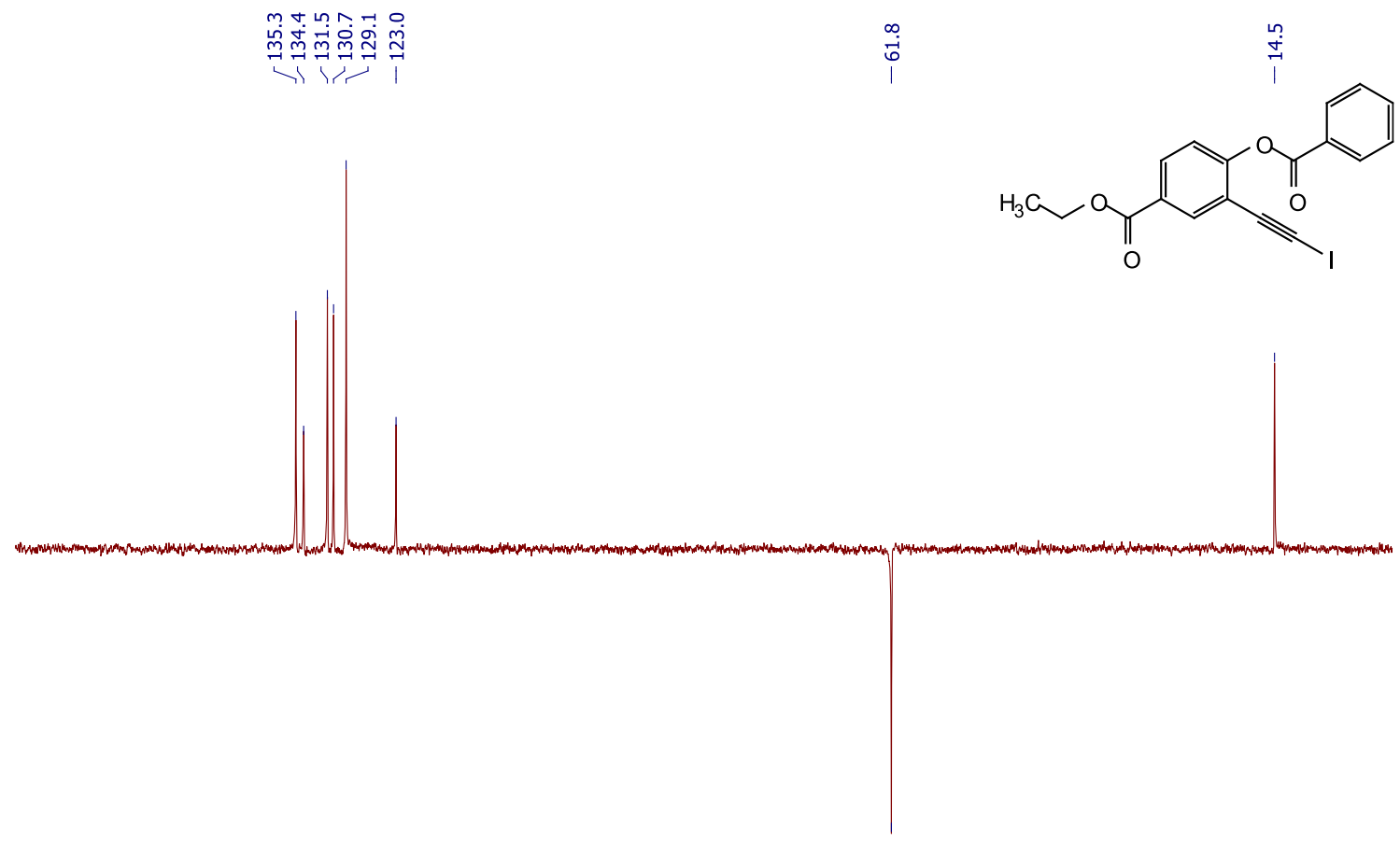

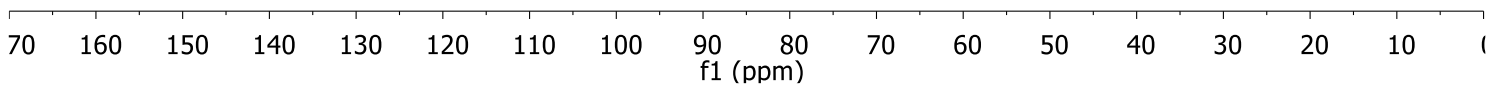

1j ${ }^{1} \mathrm{H}$ NMR spectra $\left(\mathrm{CD}_{2} \mathrm{Cl}_{2}\right)$
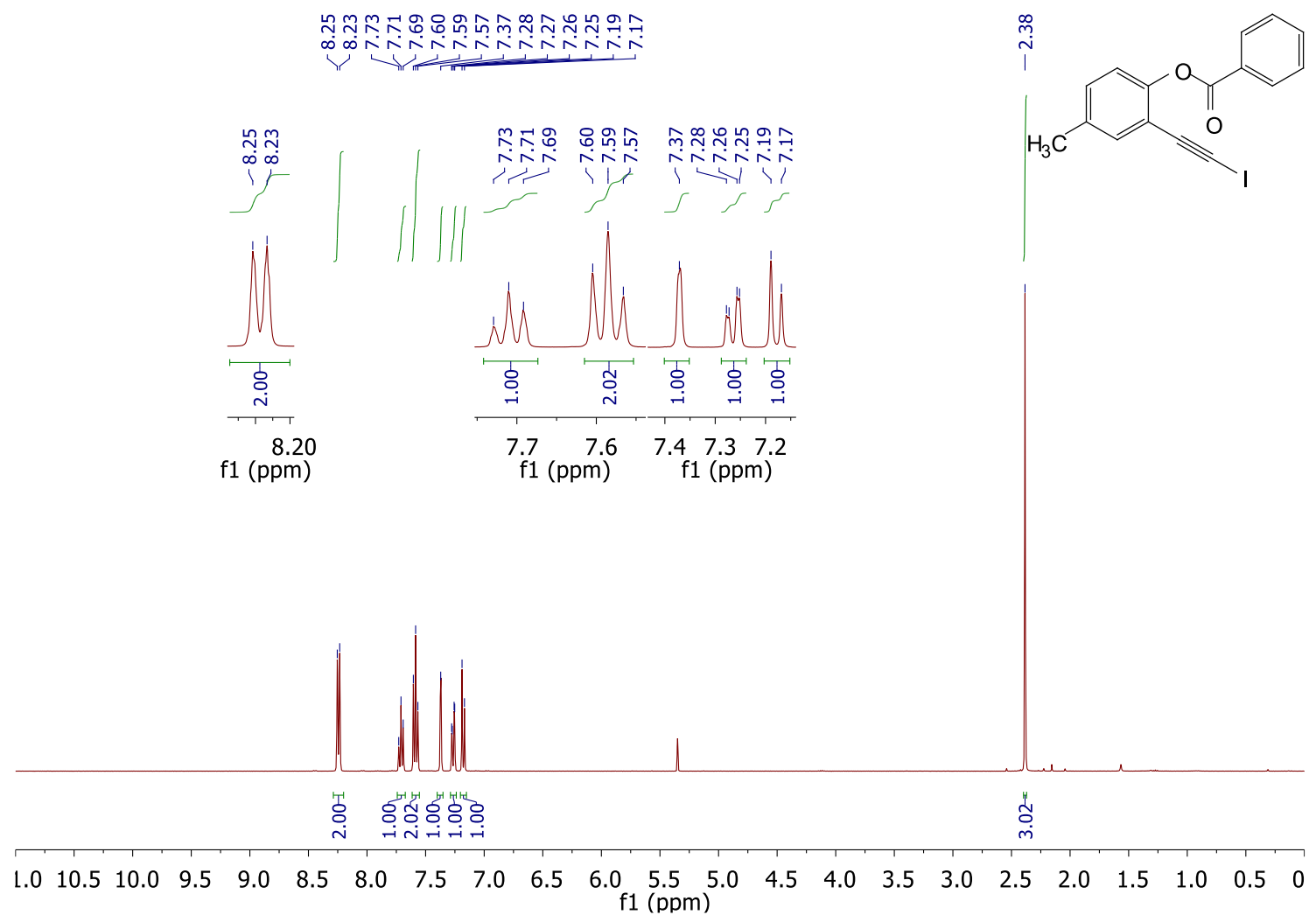
1j ${ }^{13} \mathrm{C}$ NMR spectra $\left(\mathrm{CD}_{2} \mathrm{Cl}_{2}\right)$

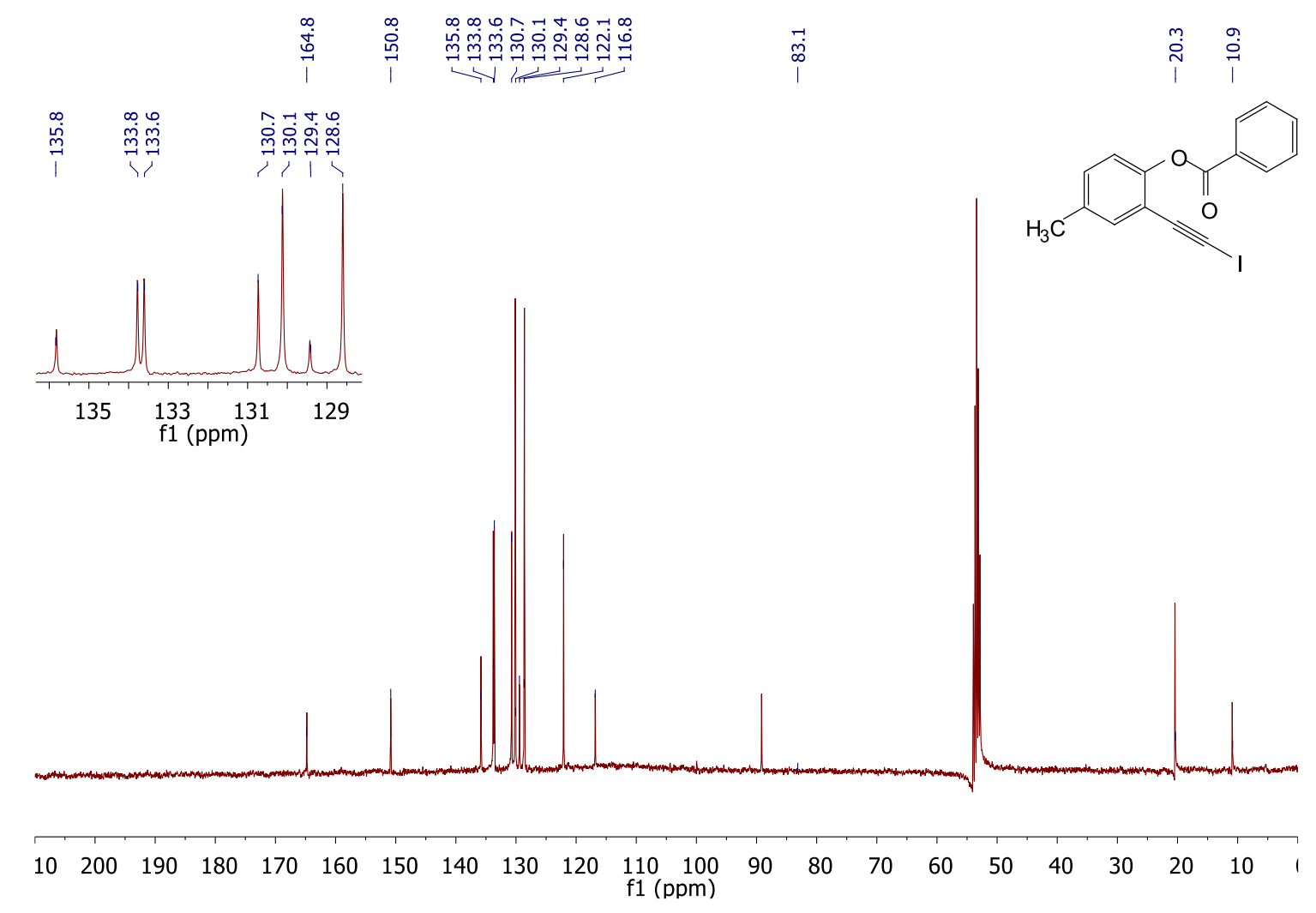

1j DEPT NMR spectra $\left(\mathrm{CD}_{2} \mathrm{Cl}_{2}\right)$

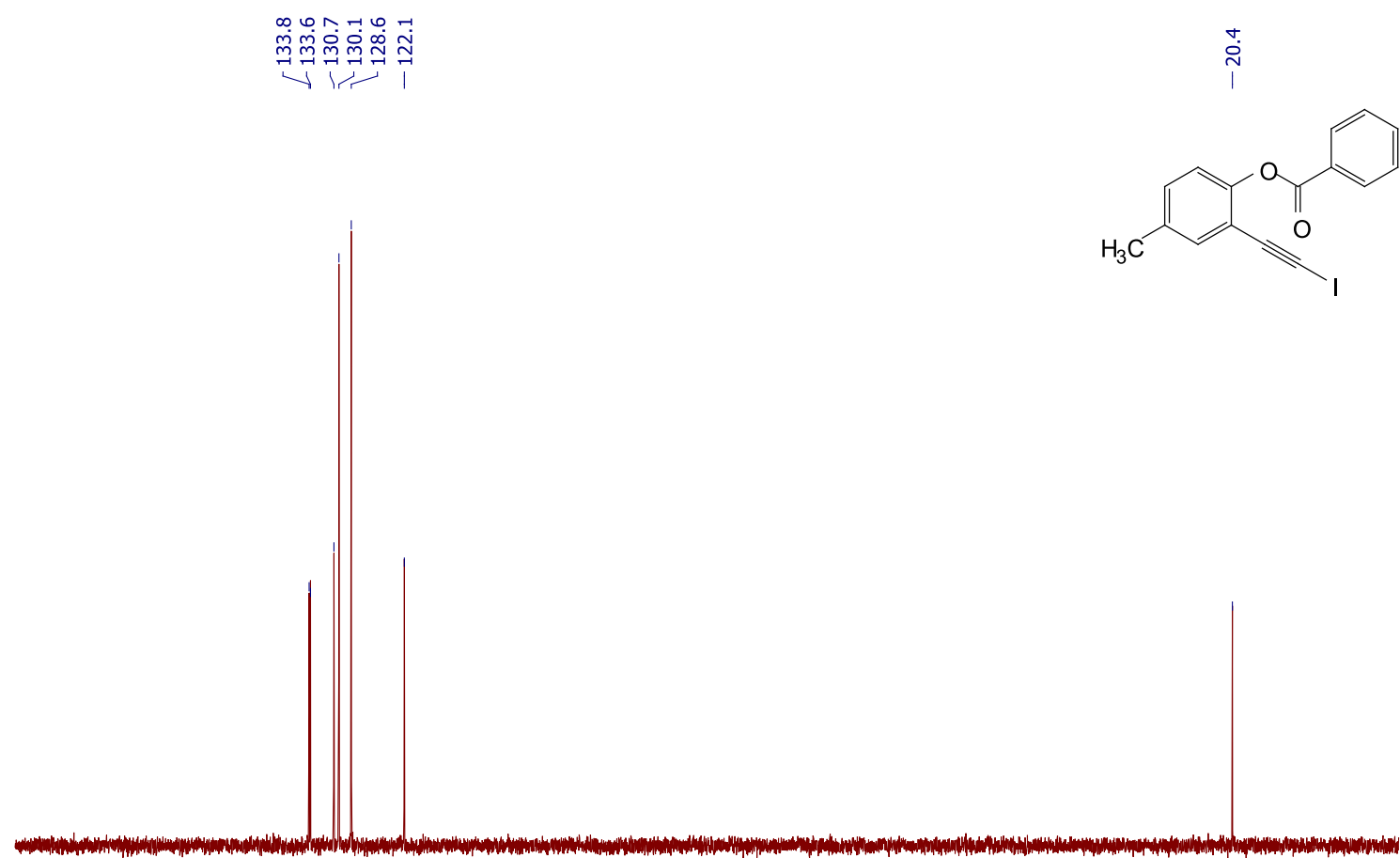

160

150

$140 \quad 130$

120

$\begin{array}{lr}90 & 80 \\ \mathrm{f} 1(\mathrm{ppm})\end{array}$

70

60

$50 \quad 40$

$\begin{array}{llll}30 & 20 \quad 10 \quad 1\end{array}$ 


\section{1k ${ }^{1} \mathrm{H}$ NMR spectra $\left(\mathrm{CD}_{2} \mathrm{Cl}_{2}\right)$}

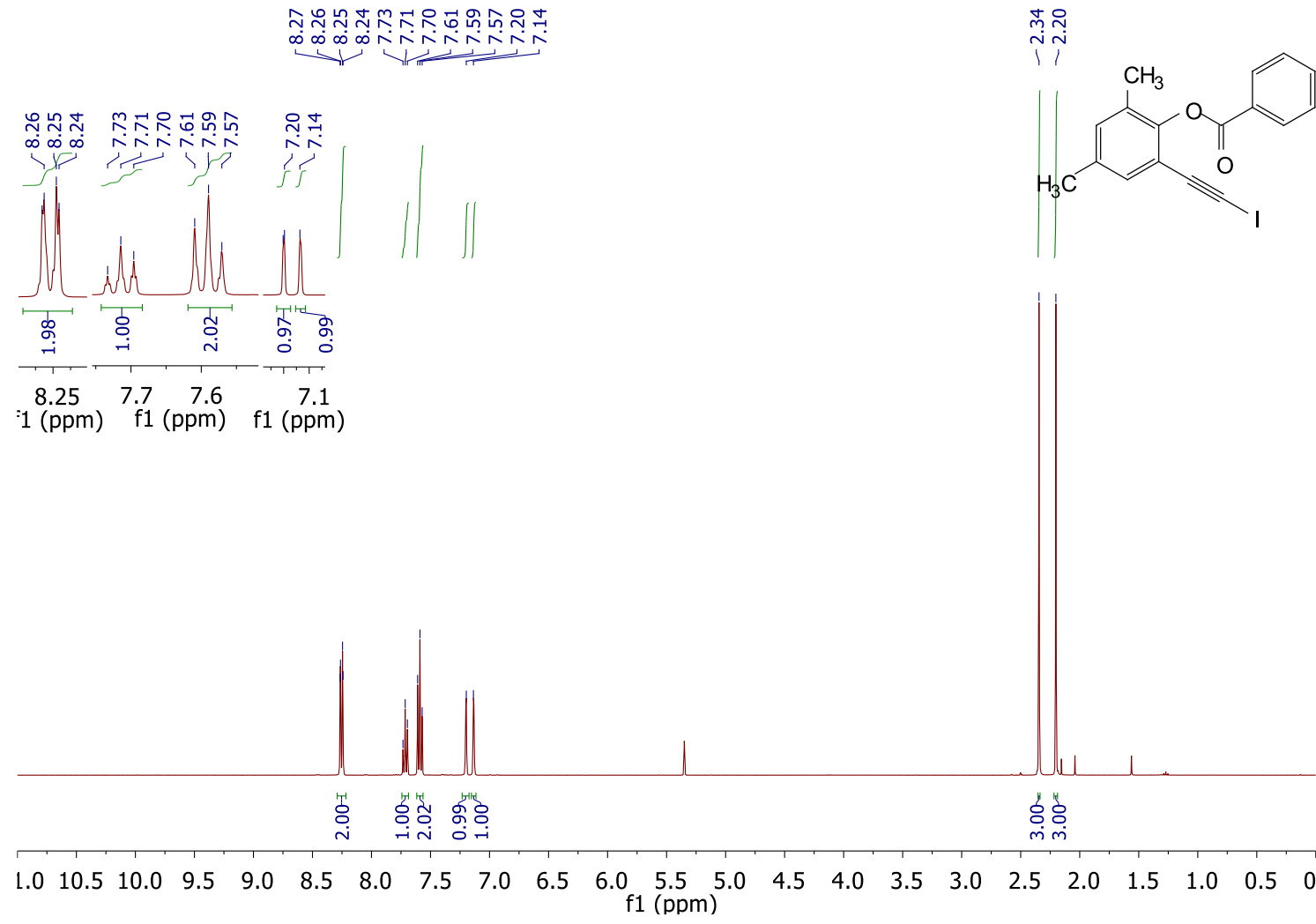

$1 \mathrm{k}{ }^{13} \mathrm{C}$ NMR spectra $\left(\mathrm{CD}_{2} \mathrm{Cl}_{2}\right)$

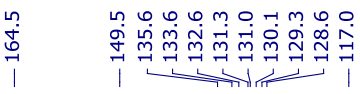

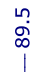

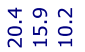
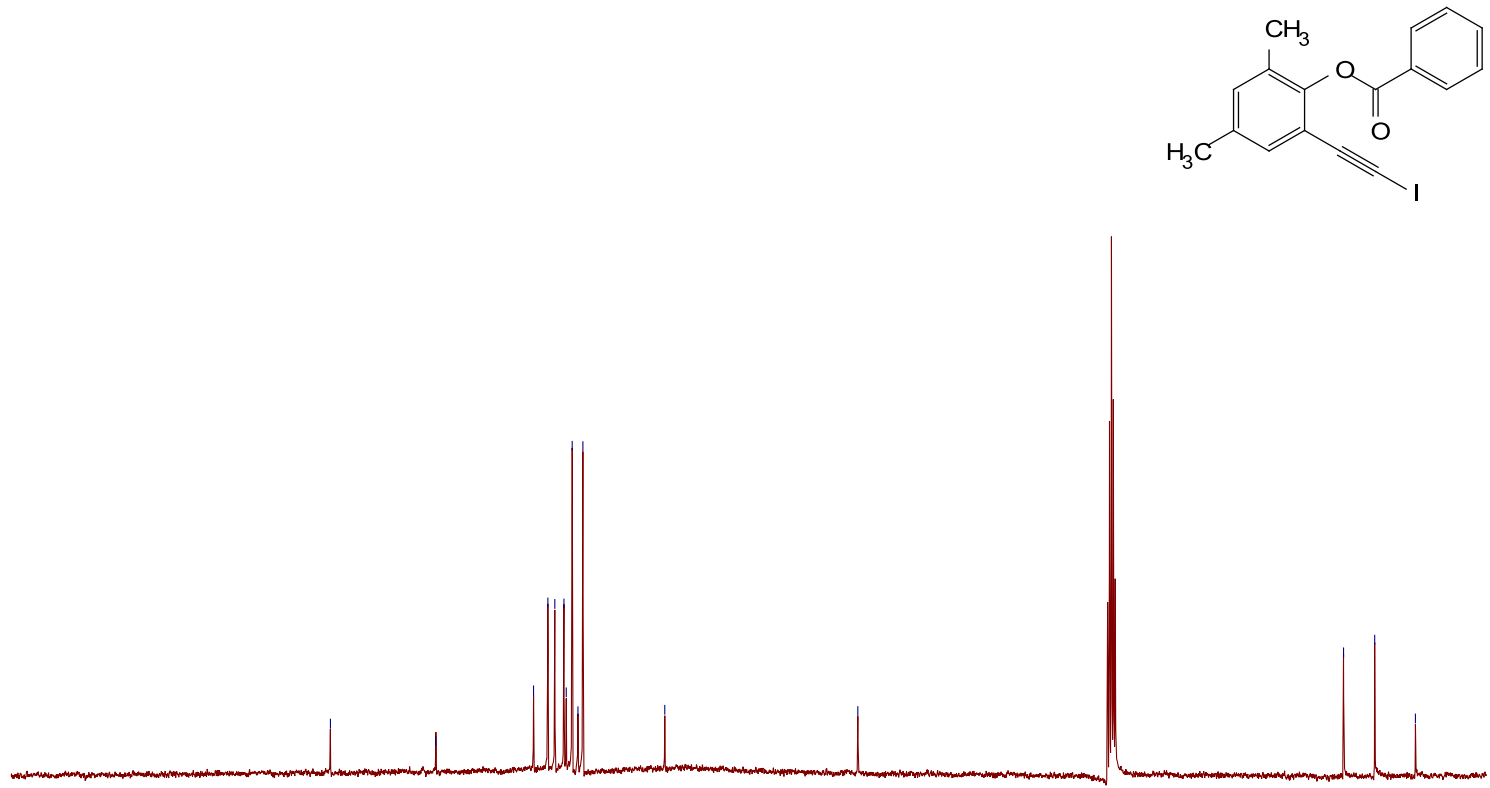

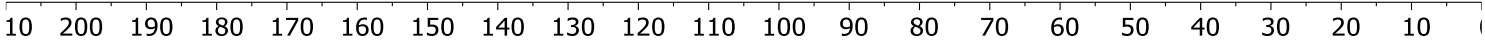
f1 (ppm) 


\section{$1 \quad{ }^{1} \mathrm{H}$ NMR spectra $\left(\mathrm{CD}_{2} \mathrm{Cl}_{2}\right)$}

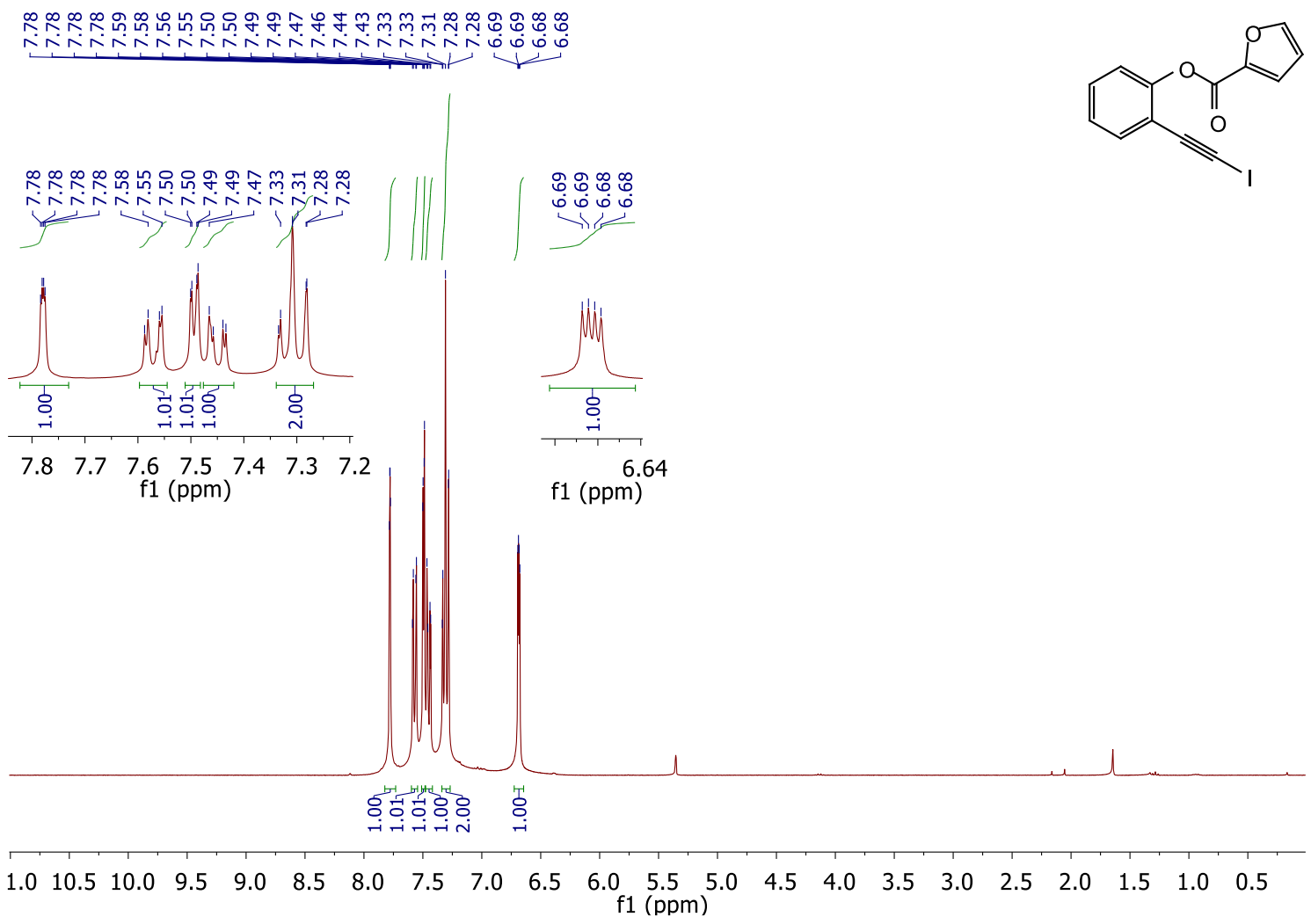

$11 \quad{ }^{13} \mathrm{C}$ NMR spectra $\left(\mathrm{CD}_{2} \mathrm{Cl}_{2}\right)$
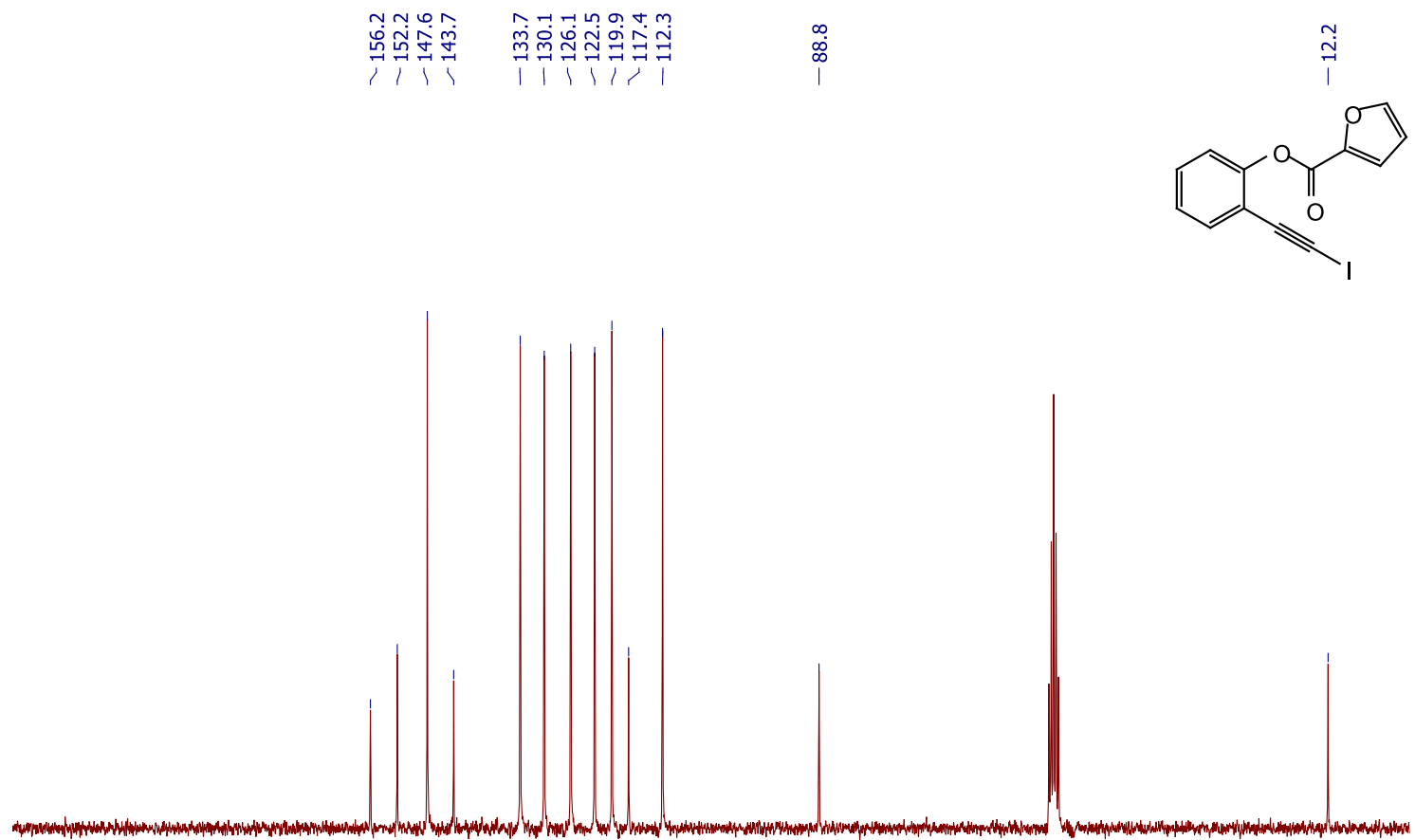

$\begin{array}{llllllllllllllllllllll}10 & 200 & 190 & 180 & 170 & 160 & 150 & 140 & 130 & 120 & \begin{array}{c}110 \\ \mathrm{f} 1(\mathrm{ppm})\end{array} & 90 & 80 & 70 & 60 & 50 & 40 & 30 & 20 & 10 & 1\end{array}$ 
1 DEPT NMR spectra $\left(\mathrm{CD}_{2} \mathrm{Cl}_{2}\right)$

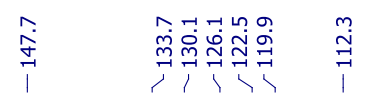
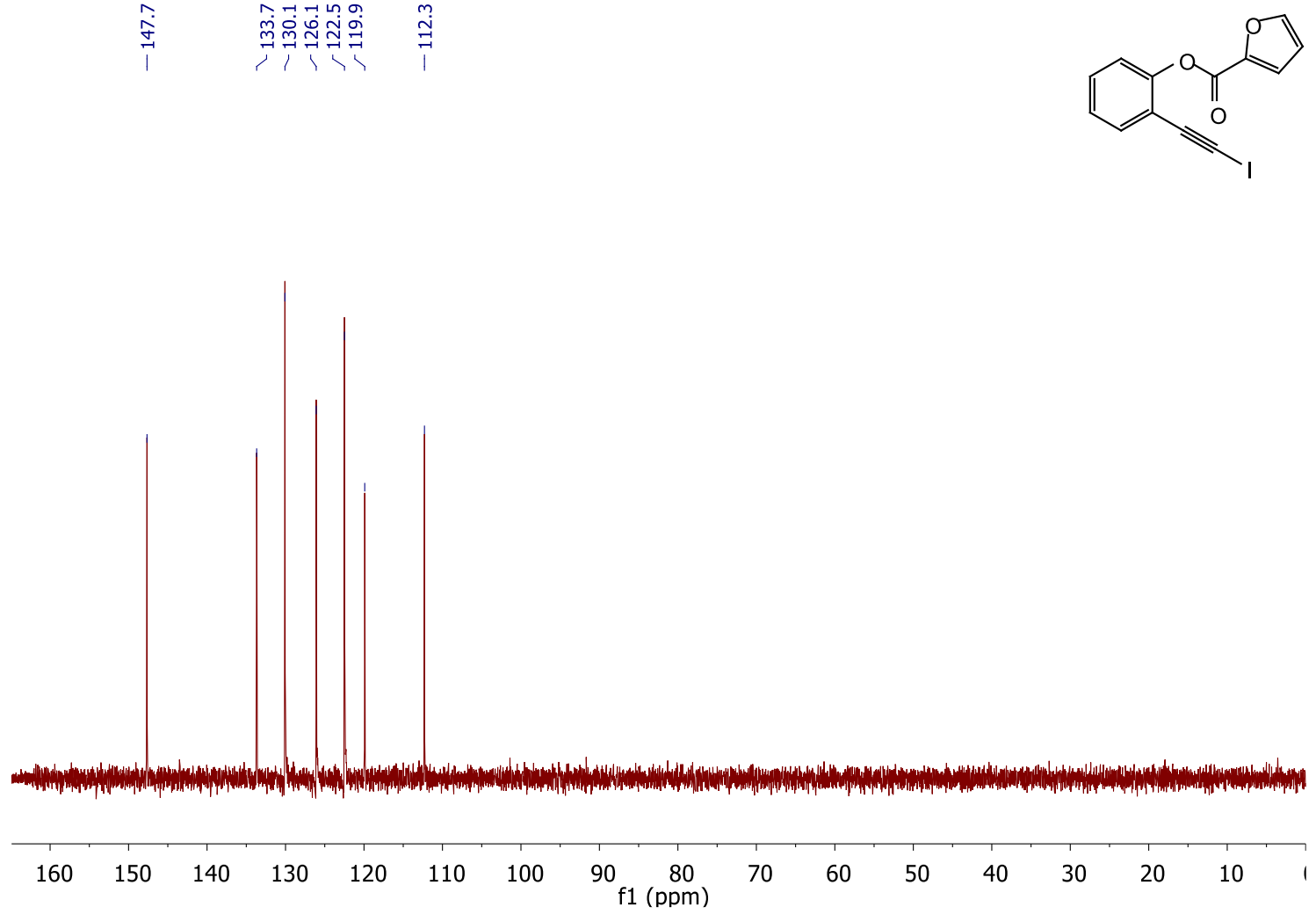

$1 \mathrm{~m}{ }^{1} \mathrm{H}$ NMR spectra $\left(\mathrm{CD}_{2} \mathrm{Cl}_{2}\right)$

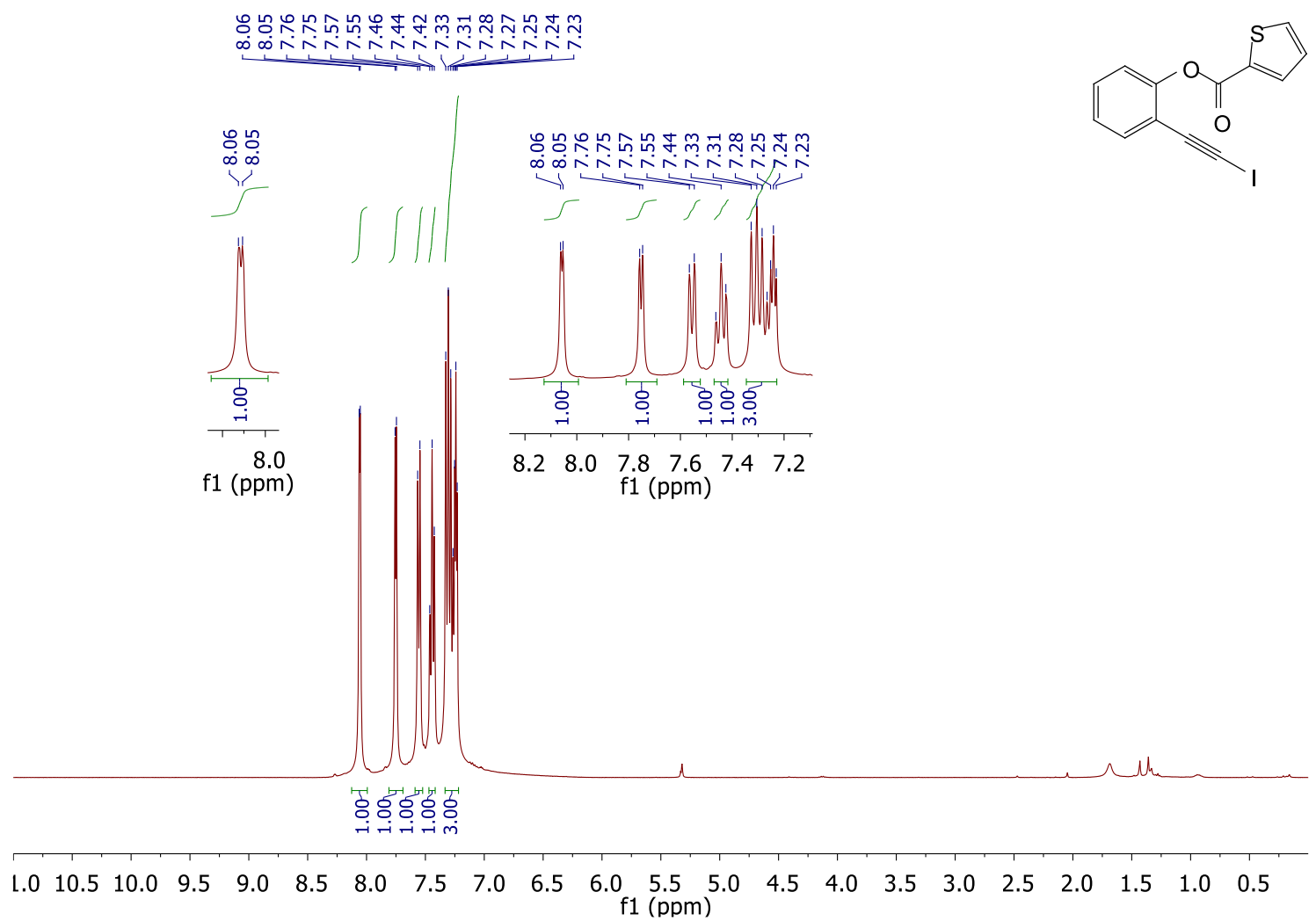


$1 \mathrm{~m} \quad{ }^{13} \mathrm{C}$ NMR spectra $\left(\mathrm{CD}_{2} \mathrm{Cl}_{2}\right)$
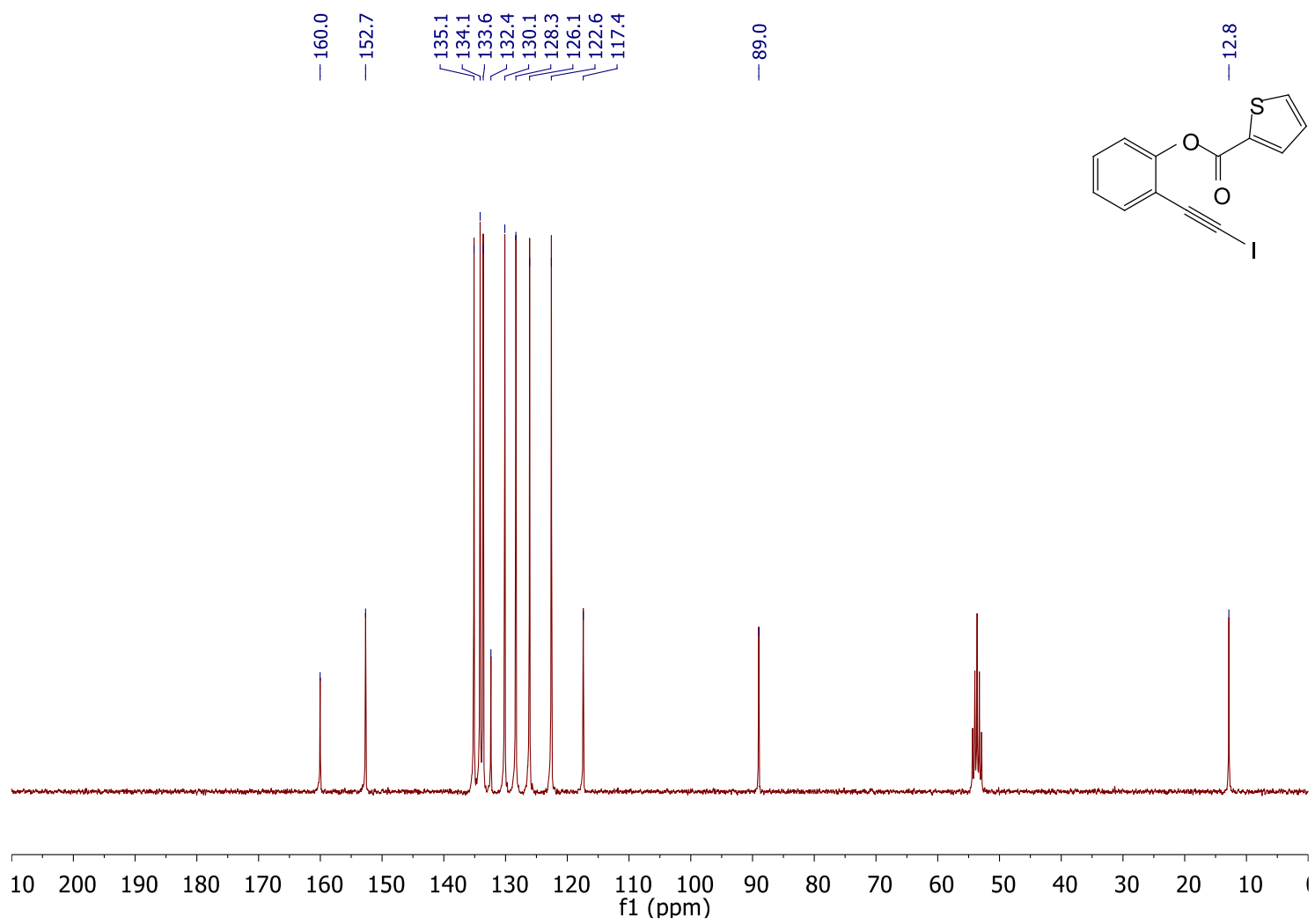

1n ${ }^{1} \mathrm{H}$ NMR spectra $\left(\mathrm{CD}_{2} \mathrm{Cl}_{2}\right)$

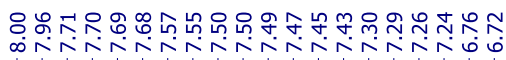
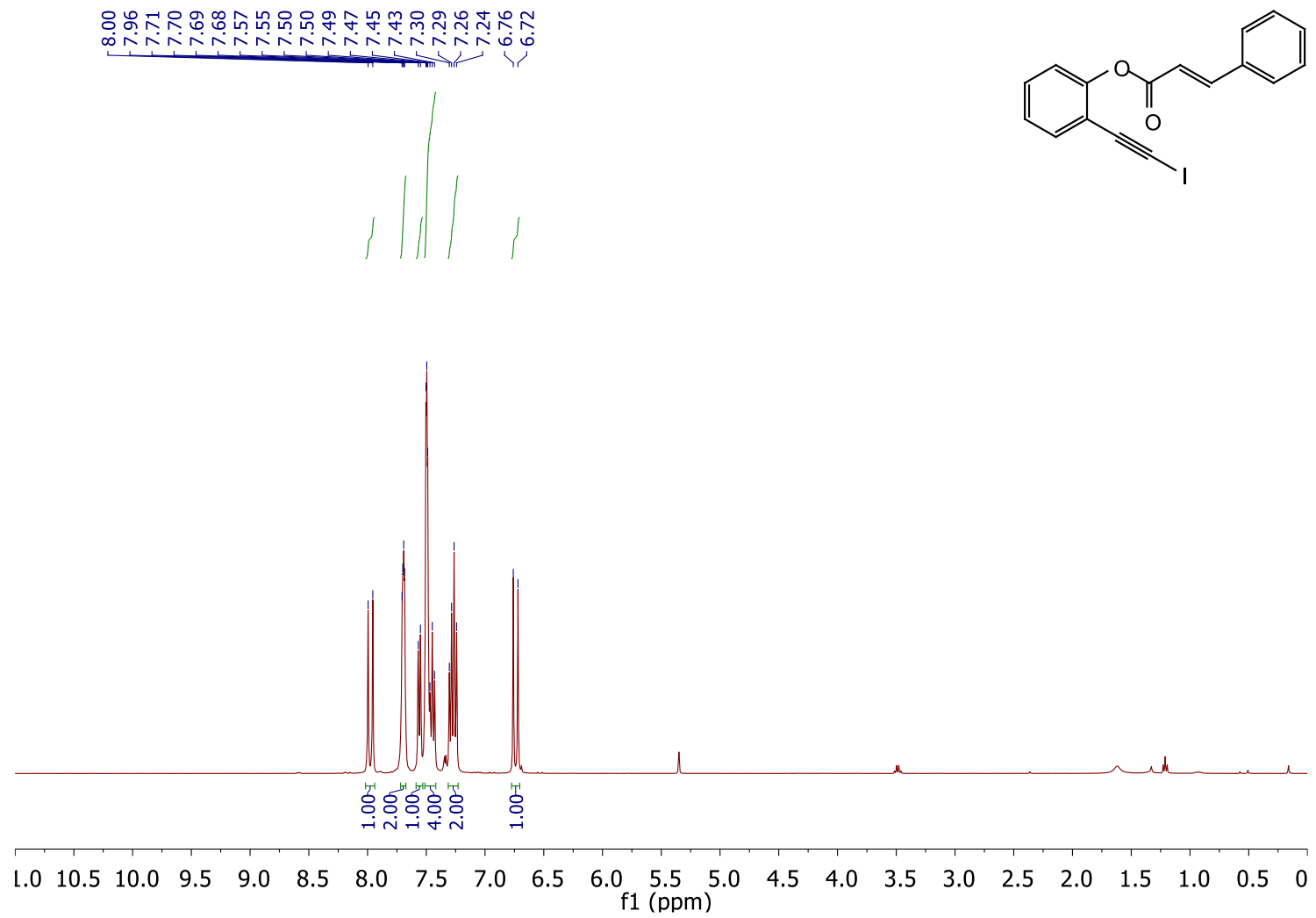


\section{1n ${ }^{13} \mathrm{C}$ NMR spectra $\left(\mathrm{CD}_{2} \mathrm{Cl}_{2}\right)$}

年
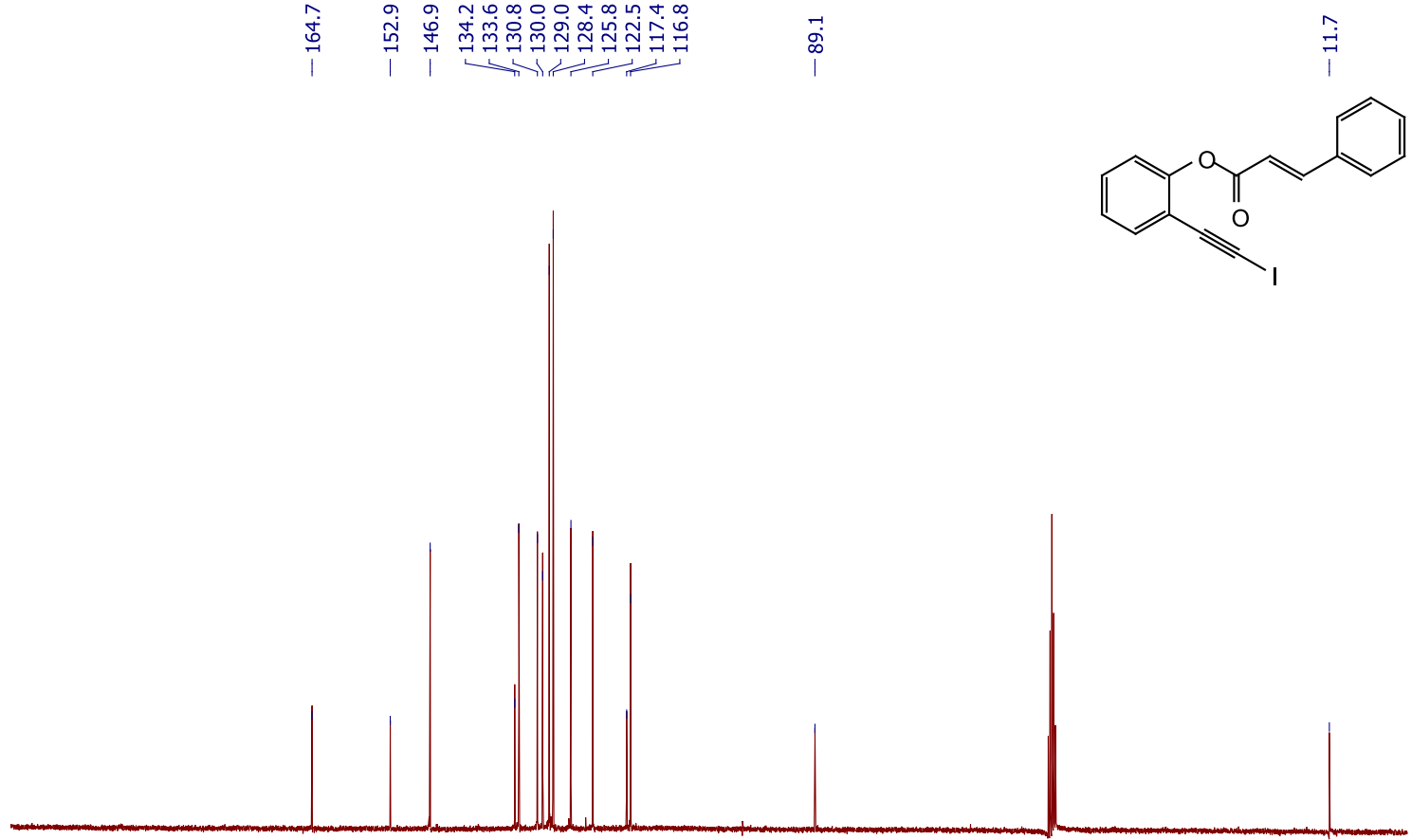

$\begin{array}{llllllllllllllllllllll}10 & 200 & 190 & 180 & 170 & 160 & 150 & 140 & 130 & 120 & 110 & 100 & 90 & 80 & 70 & 60 & 50 & 40 & 30 & 20 & 10 & 1\end{array}$

$10 \quad{ }^{1} \mathrm{H}$ NMR spectra $\mathrm{CD}_{2} \mathrm{Cl}_{2}$ )

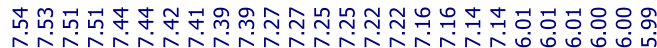

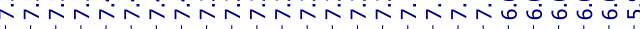

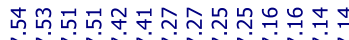

V)

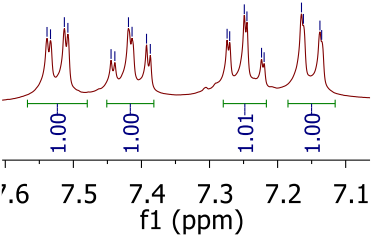

Lis
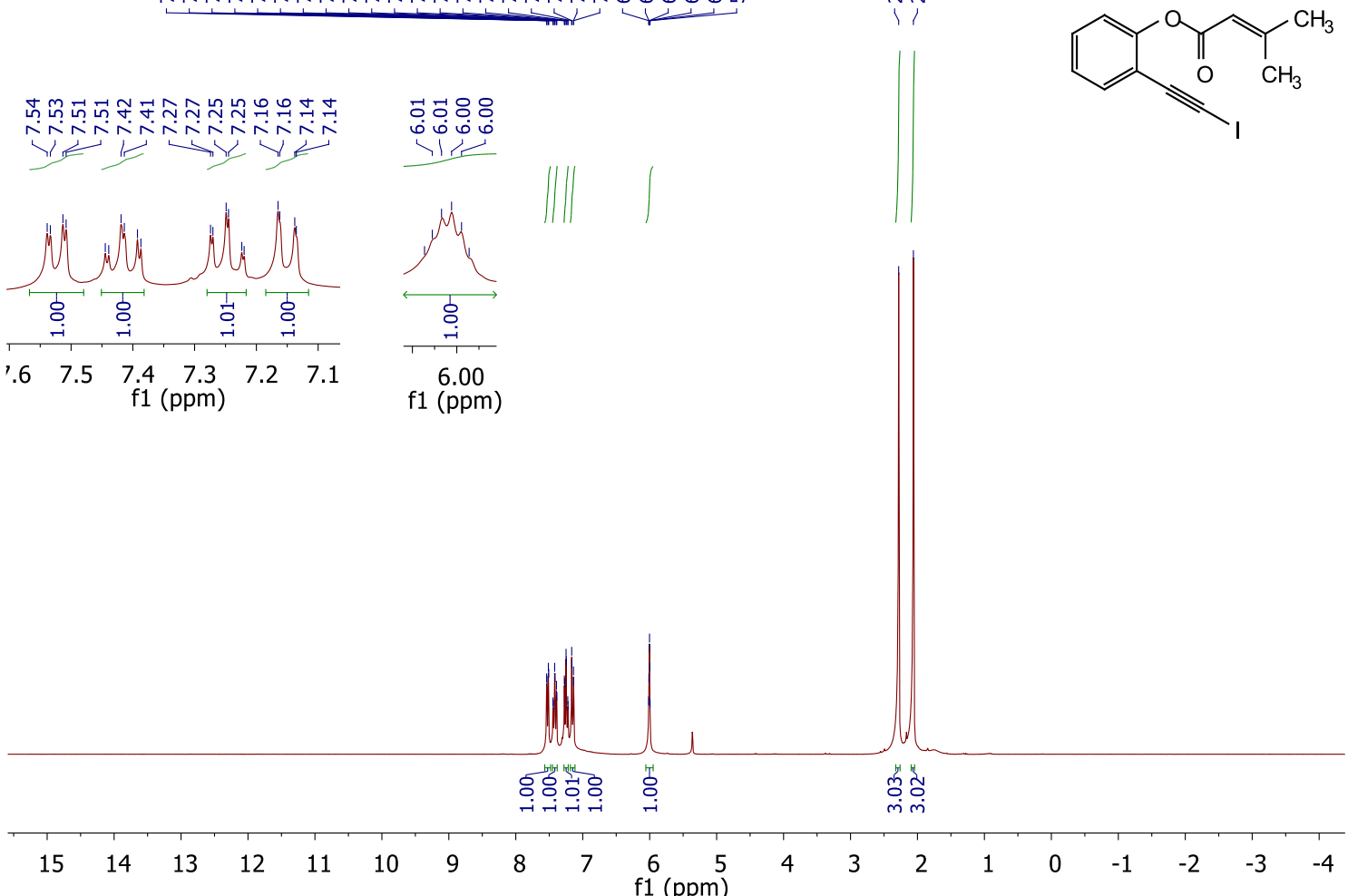
$10{ }^{13} \mathrm{C}$ NMR spectra $\left(\mathrm{CD}_{2} \mathrm{Cl}_{2}\right)$

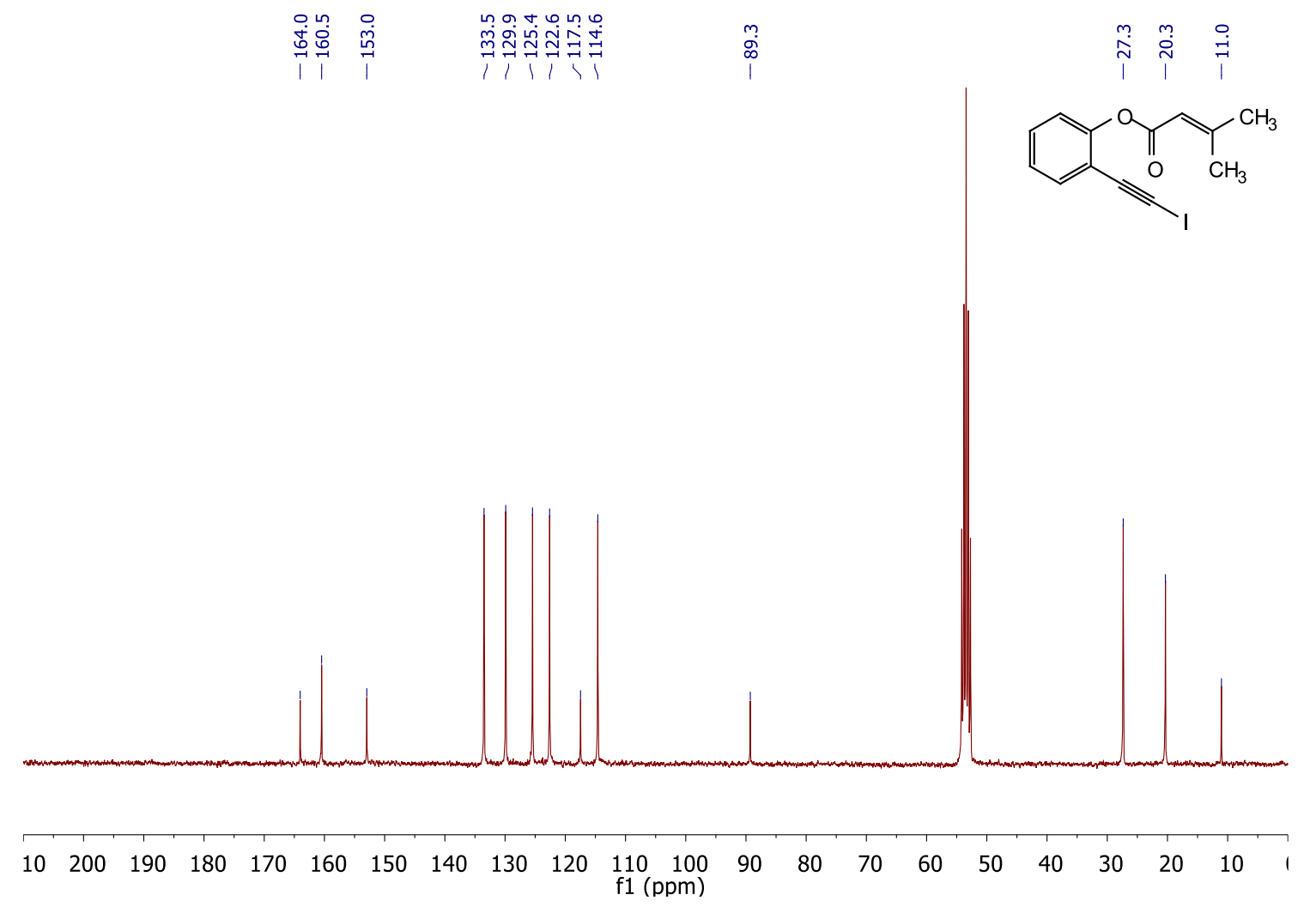

10 DEPT NMR spectra $\left(\mathrm{CD}_{2} \mathrm{Cl}_{2}\right)$
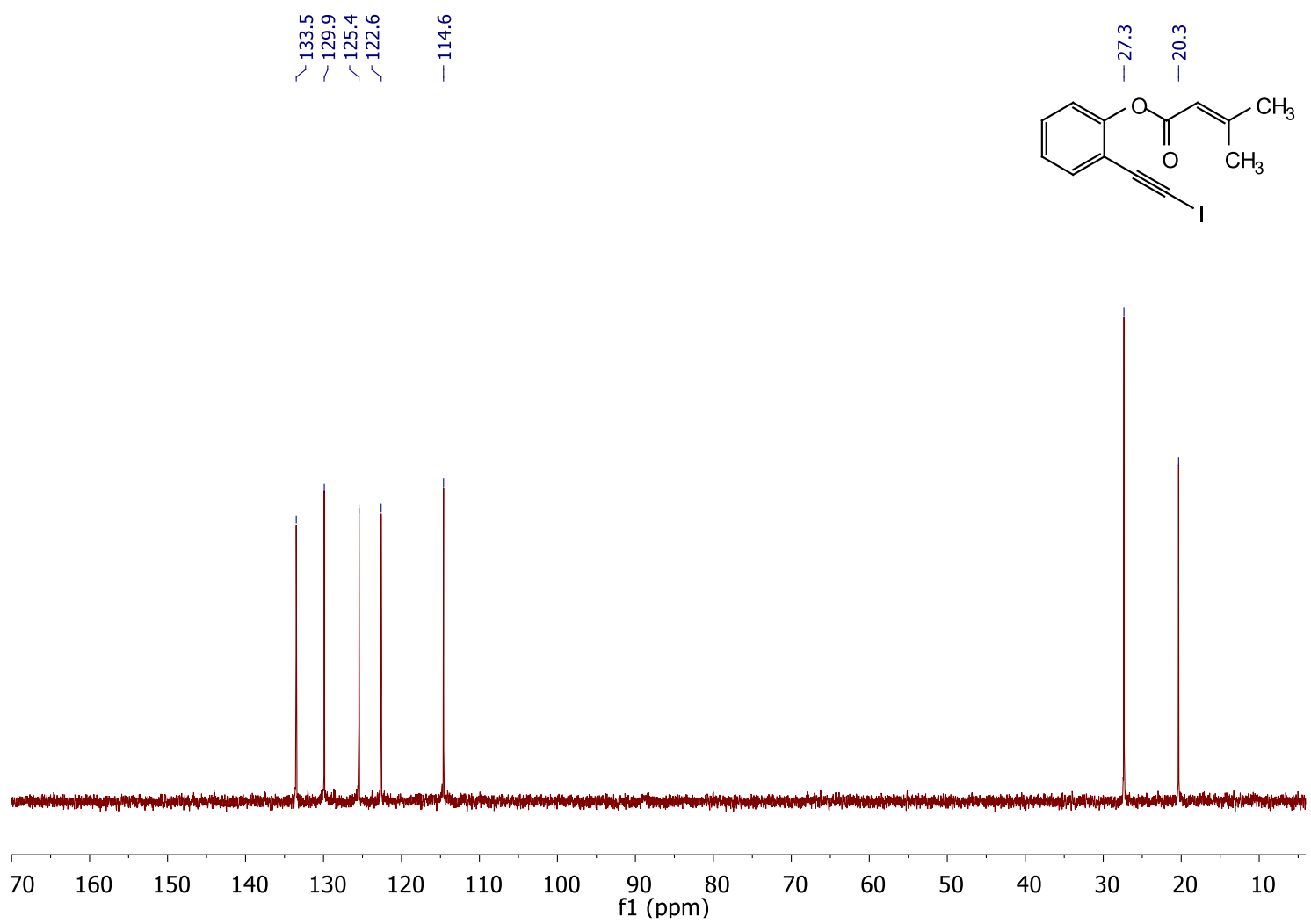
ip ${ }^{1} \mathrm{H}$ NMR spectra $\left(\mathrm{CD}_{2} \mathrm{Cl}_{2}\right)$

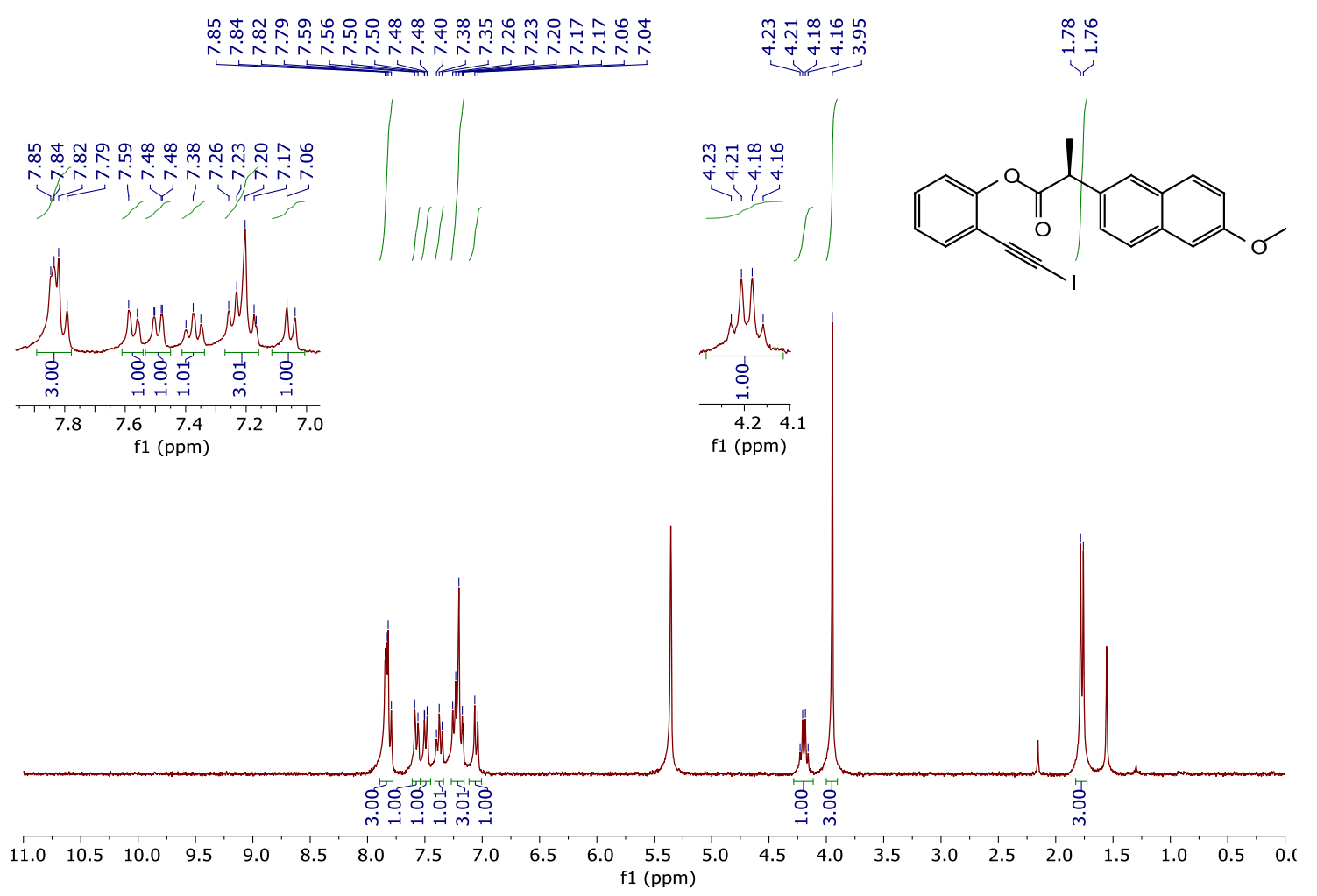

Ip ${ }^{13} \mathrm{C}$ NMR spectra $\left(\mathrm{CD}_{2} \mathrm{Cl}_{2}\right)$

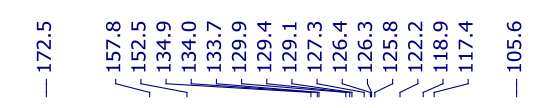
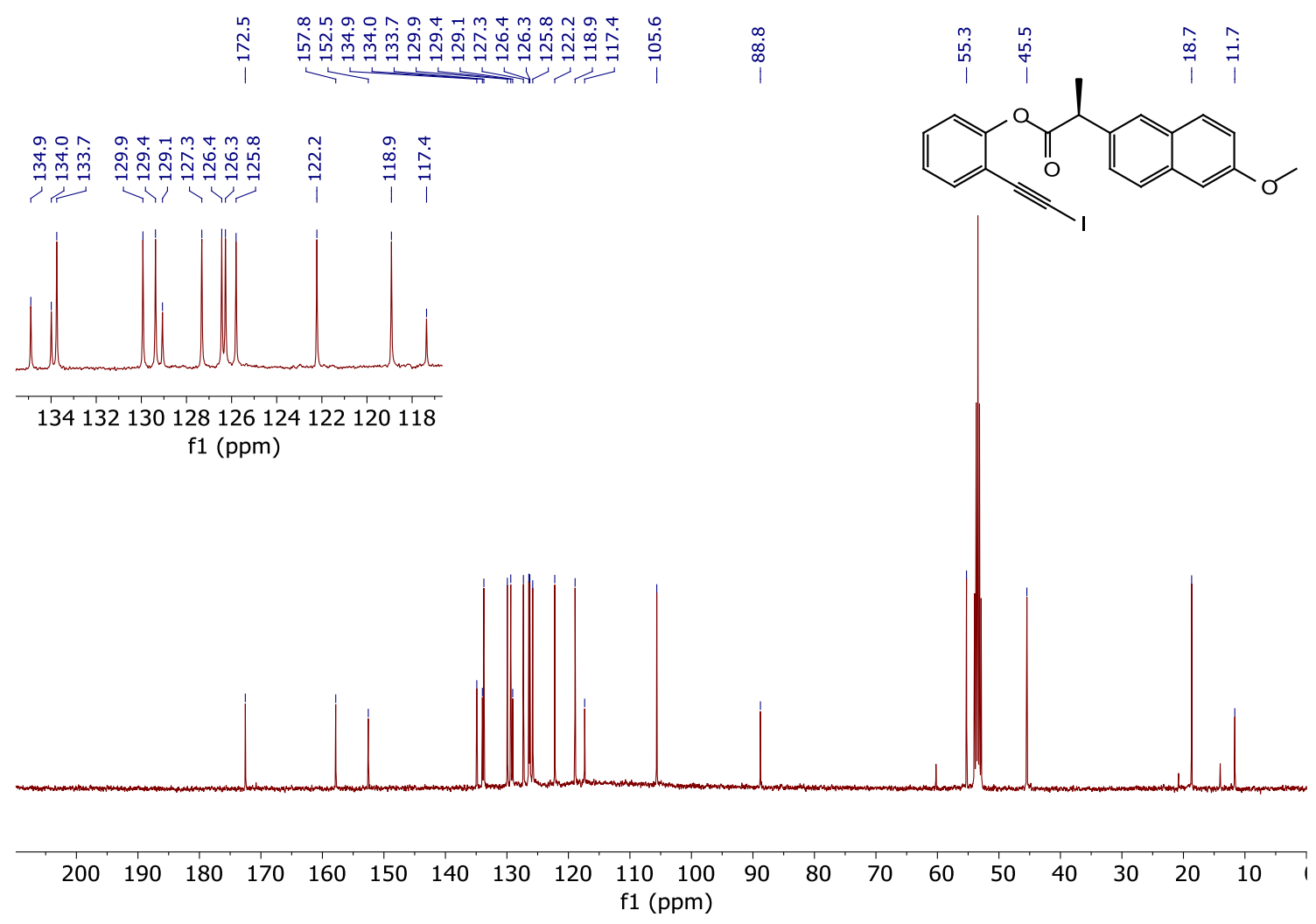

51 
1p DEPT NMR spectra $\left(\mathrm{CD}_{2} \mathrm{Cl}_{2}\right)$

$\underbrace{m}$

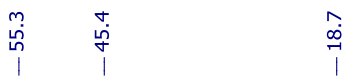
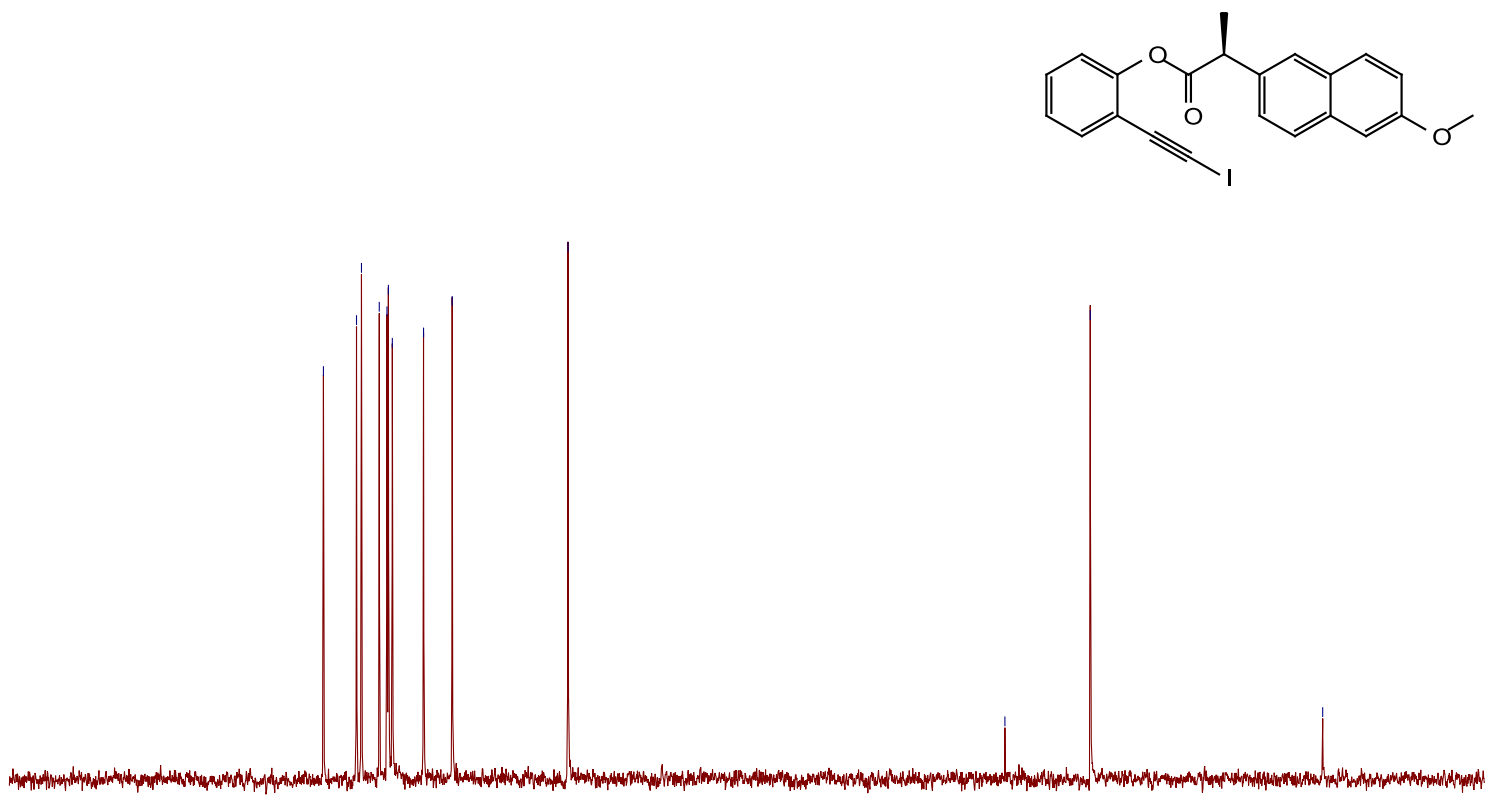

$\begin{array}{llllllllll}70 & 160 & 150 & 140 & 130 & 120 & 110 & 100 & 90 & 80\end{array}$ f1 (ppm) 
5.2. Spectra for products (2)

2a ${ }^{1} \mathrm{H}$ NMR spectra $\left(\mathrm{CD}_{2} \mathrm{Cl}_{2}\right)$

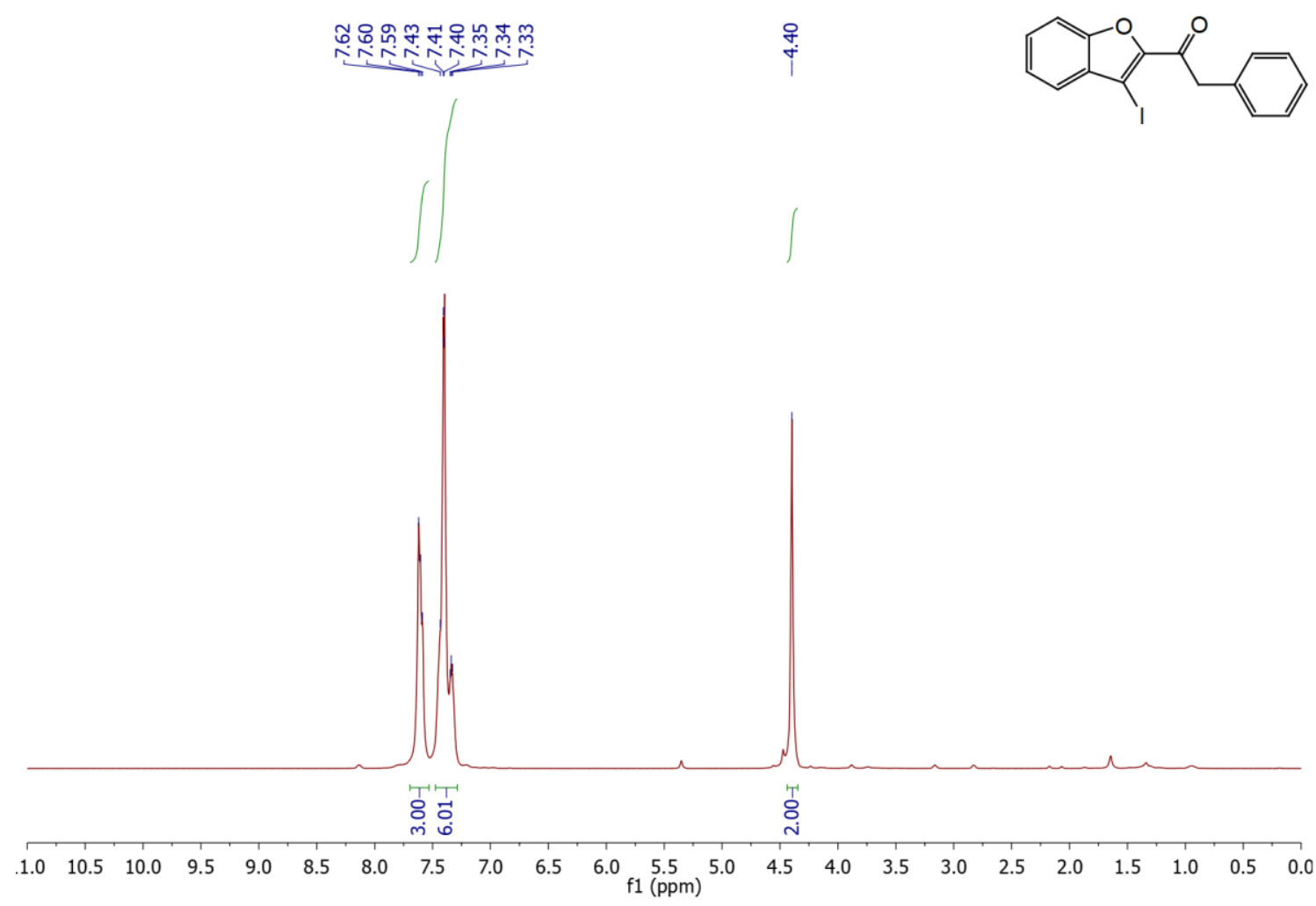

2a ${ }^{13} \mathrm{C}$ NMR spectra $\left(\mathrm{CD}_{2} \mathrm{Cl}_{2}\right)$

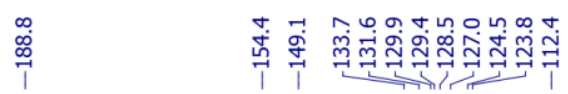

$\stackrel{\text { i }}{i}$
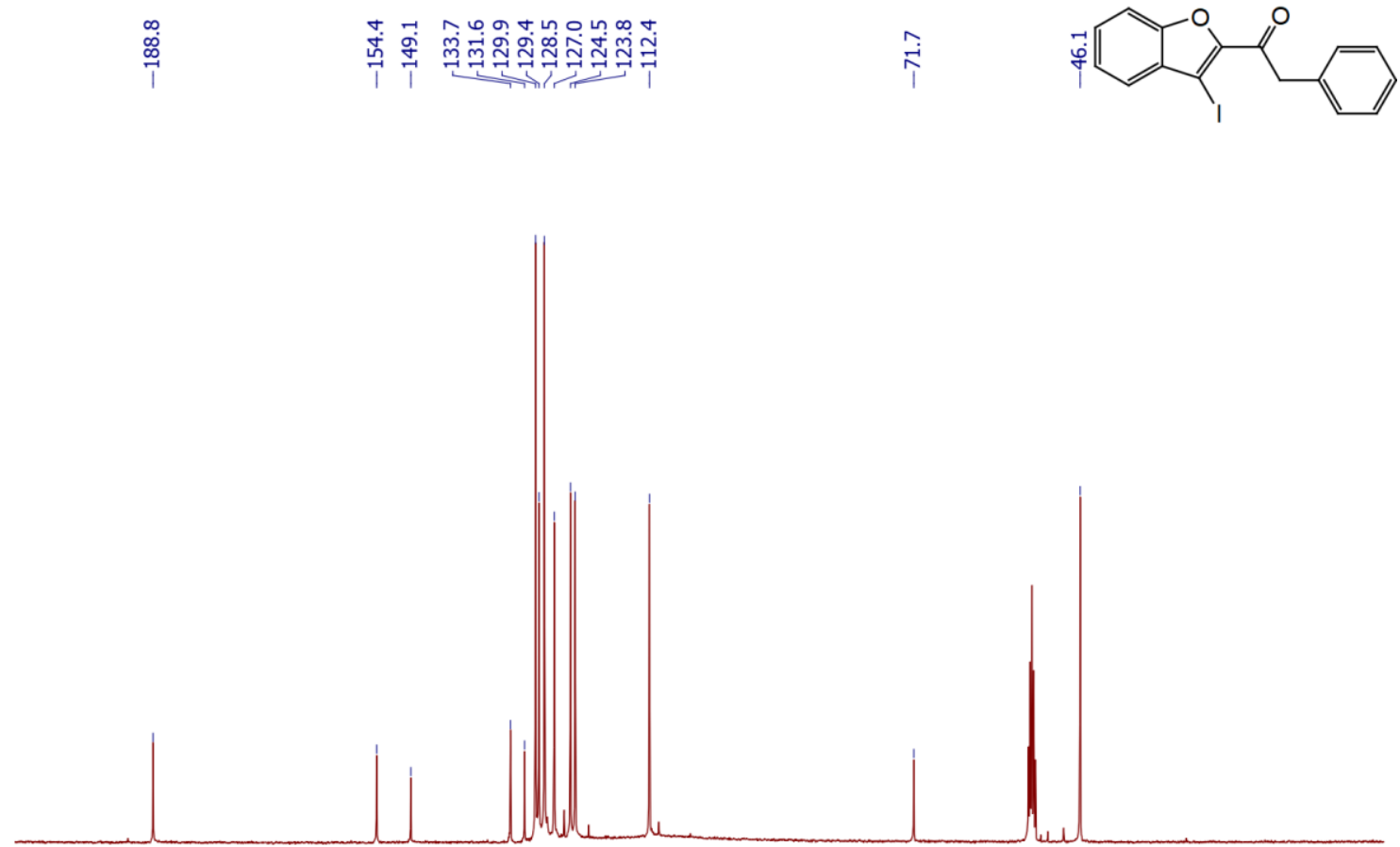

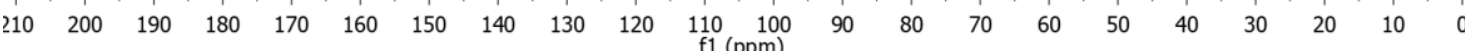




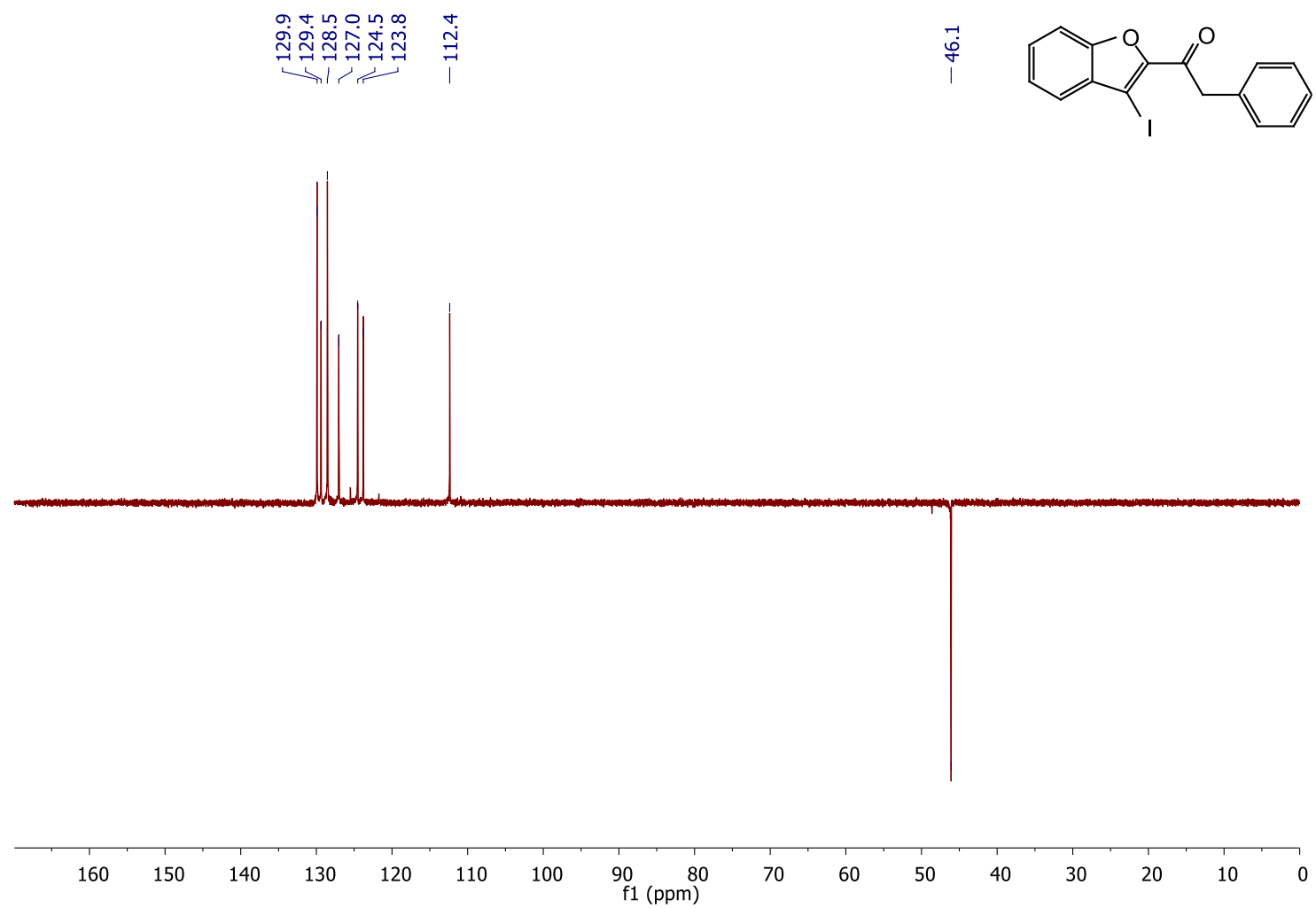

2b ${ }^{1} \mathrm{H}$ NMR spectra $\left(\mathrm{CD}_{2} \mathrm{Cl}_{2}\right)$

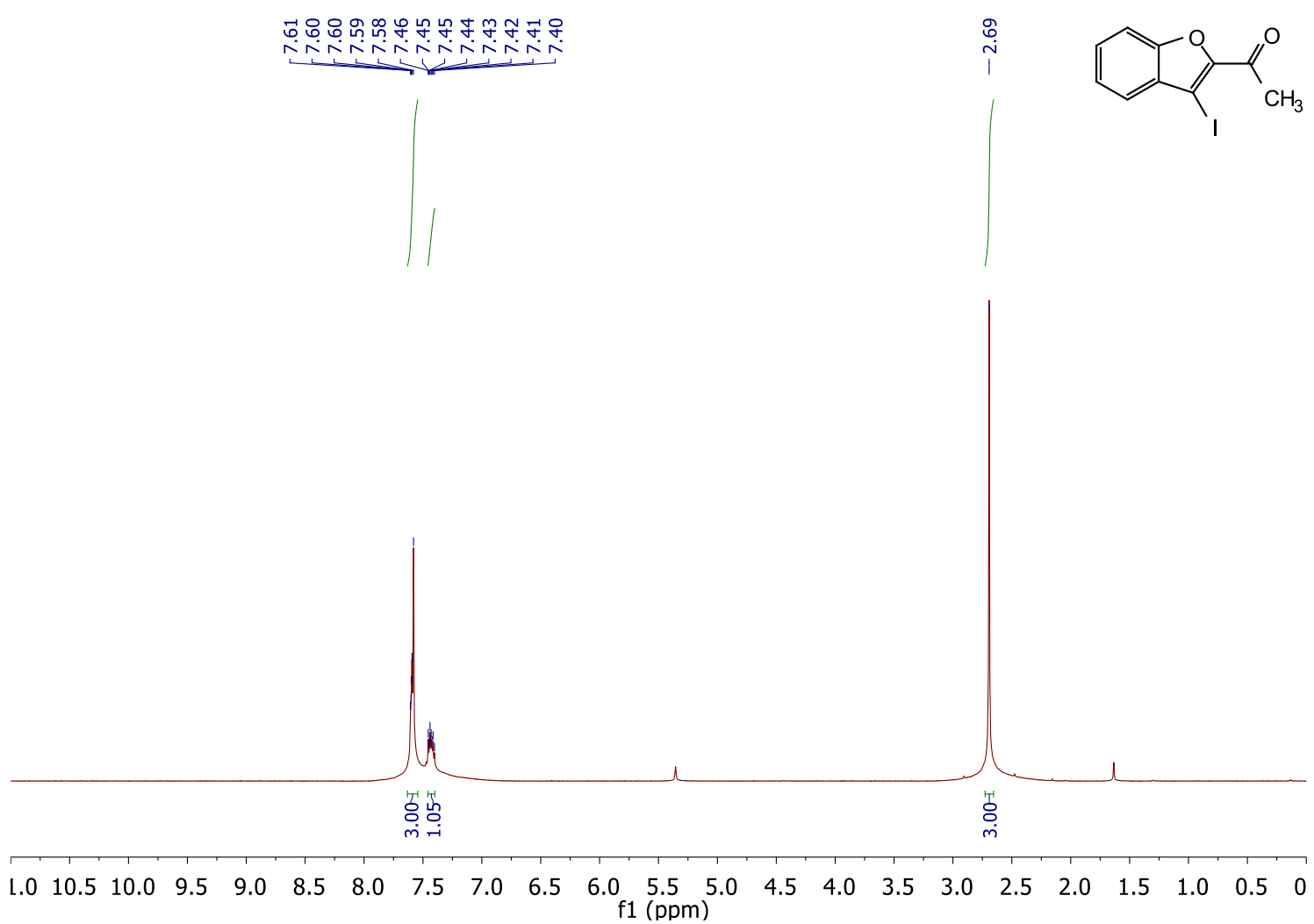


2b $\quad{ }^{13} \mathrm{C}$ NMR spectra $\left(\mathrm{CD}_{2} \mathrm{Cl}_{2}\right)$

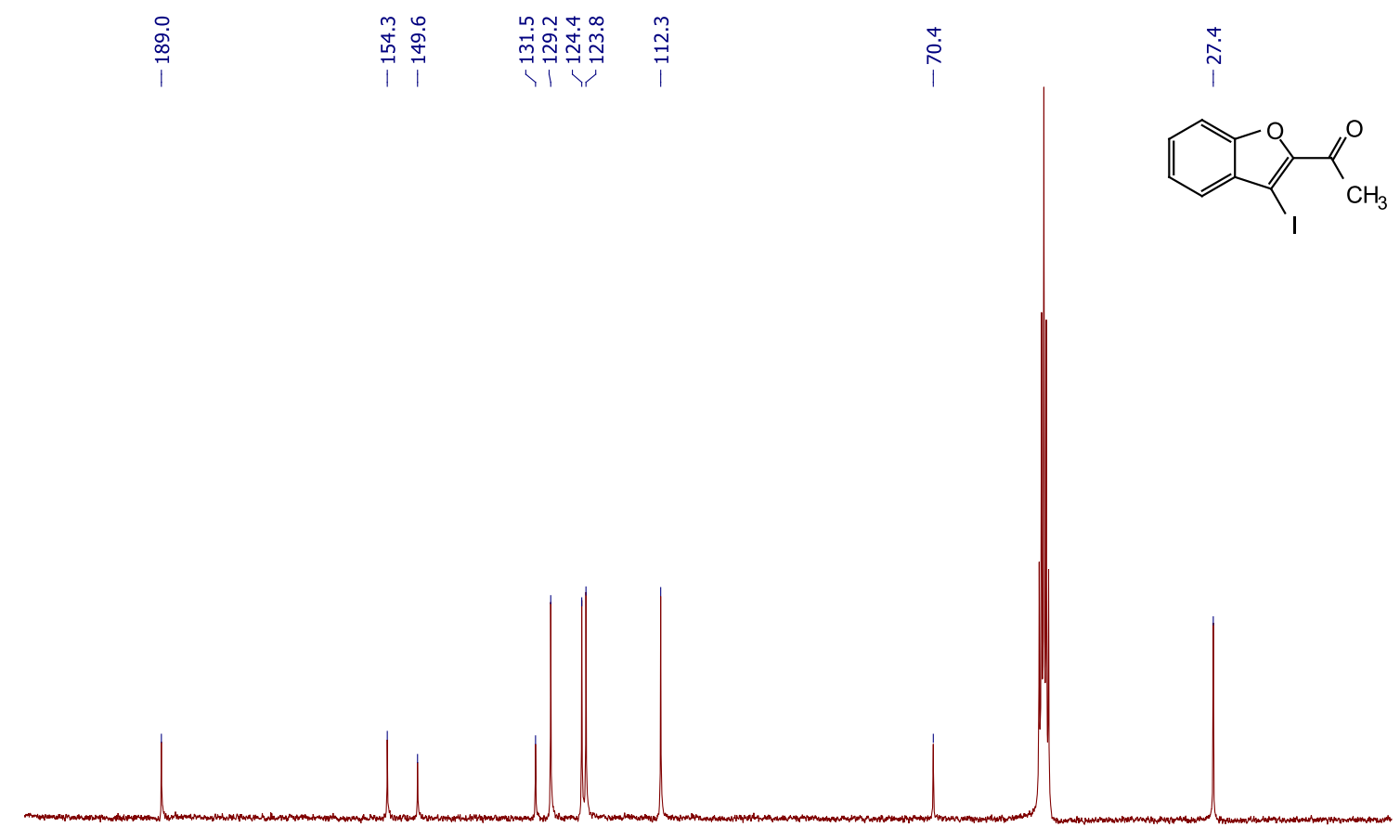

$\begin{array}{llllllllllllllllllllll}10 & 200 & 190 & 180 & 170 & 160 & 150 & 140 & 130 & 120 & \begin{array}{c}110 \\ \mathrm{f} 1(\mathrm{ppm})\end{array} & 90 & 80 & 70 & 60 & 50 & 40 & 30 & 20 & 10 & 1\end{array}$

2b DEPT NMR spectra $\left(\mathrm{CD}_{2} \mathrm{Cl}_{2}\right)$
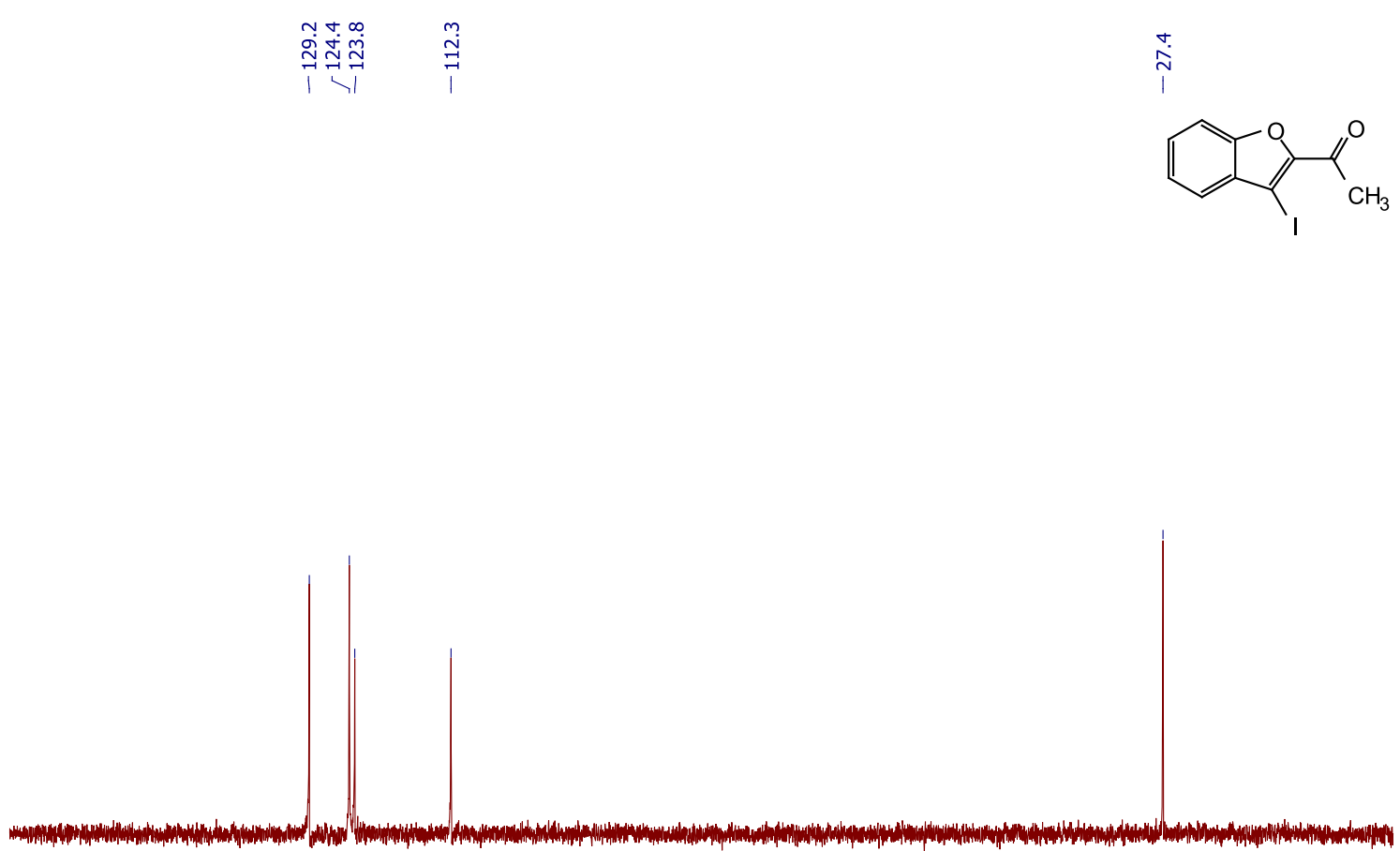


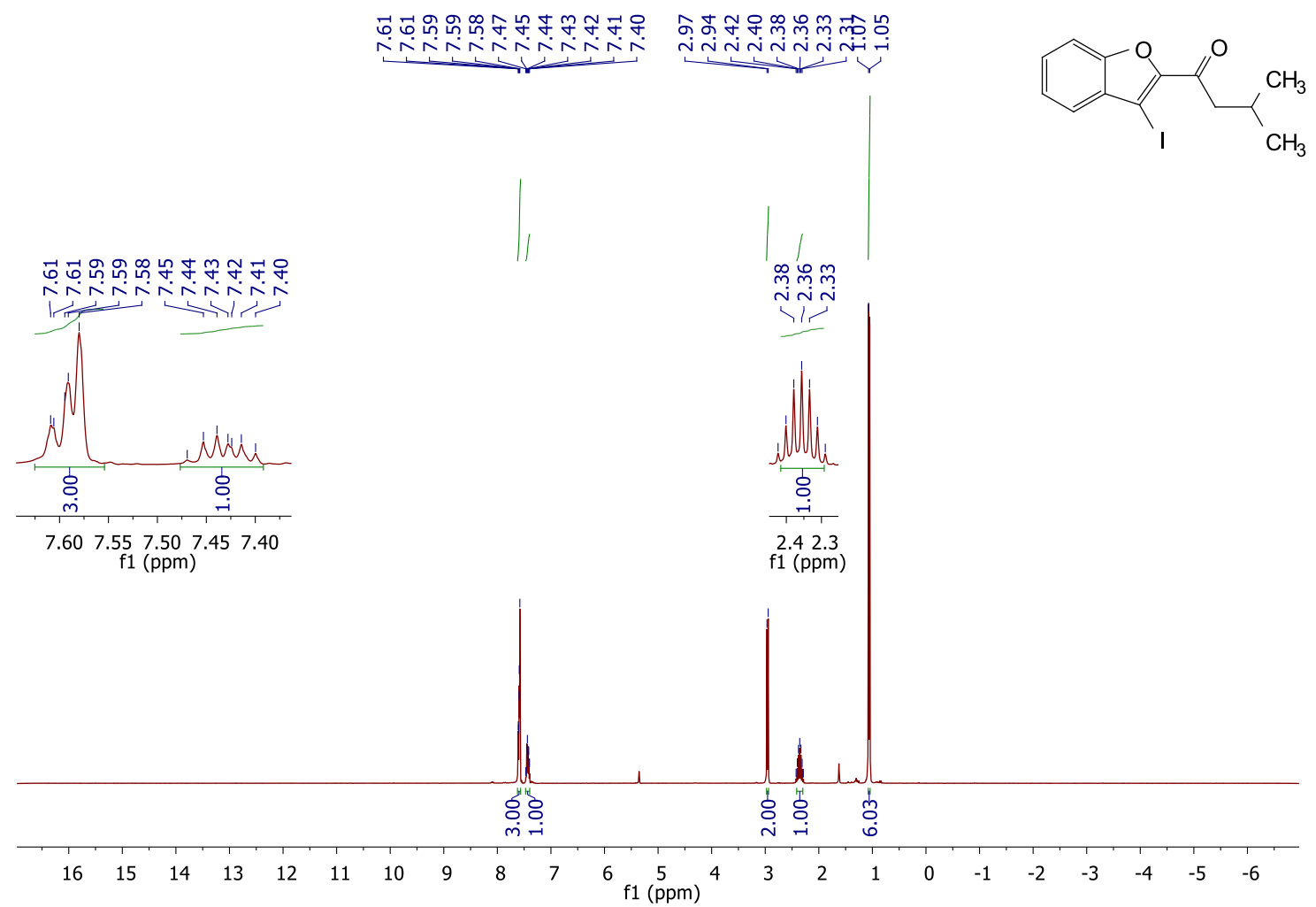

2c ${ }^{13} \mathrm{C}$ NMR spectra $\left(\mathrm{CD}_{2} \mathrm{Cl}_{2}\right)$

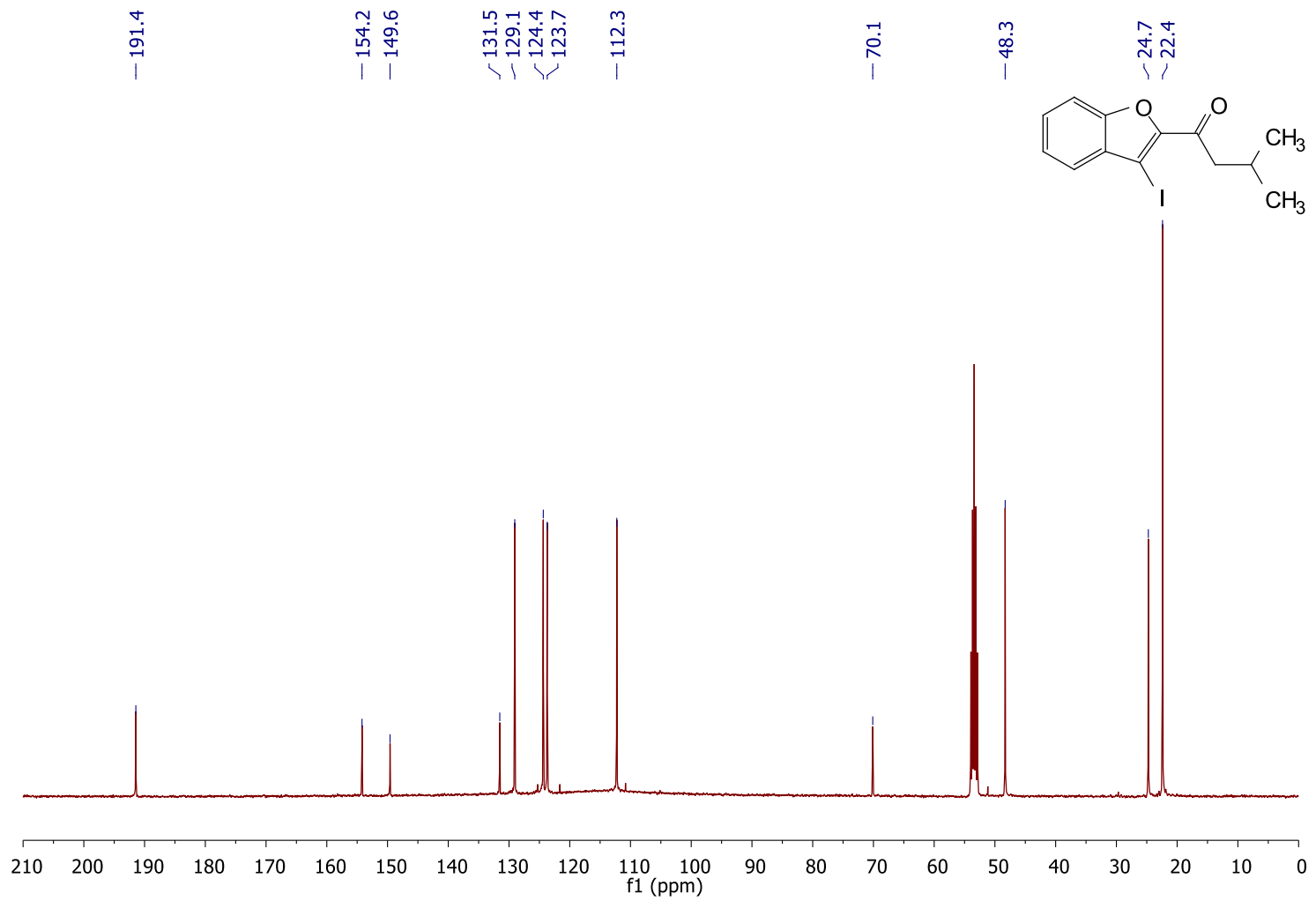




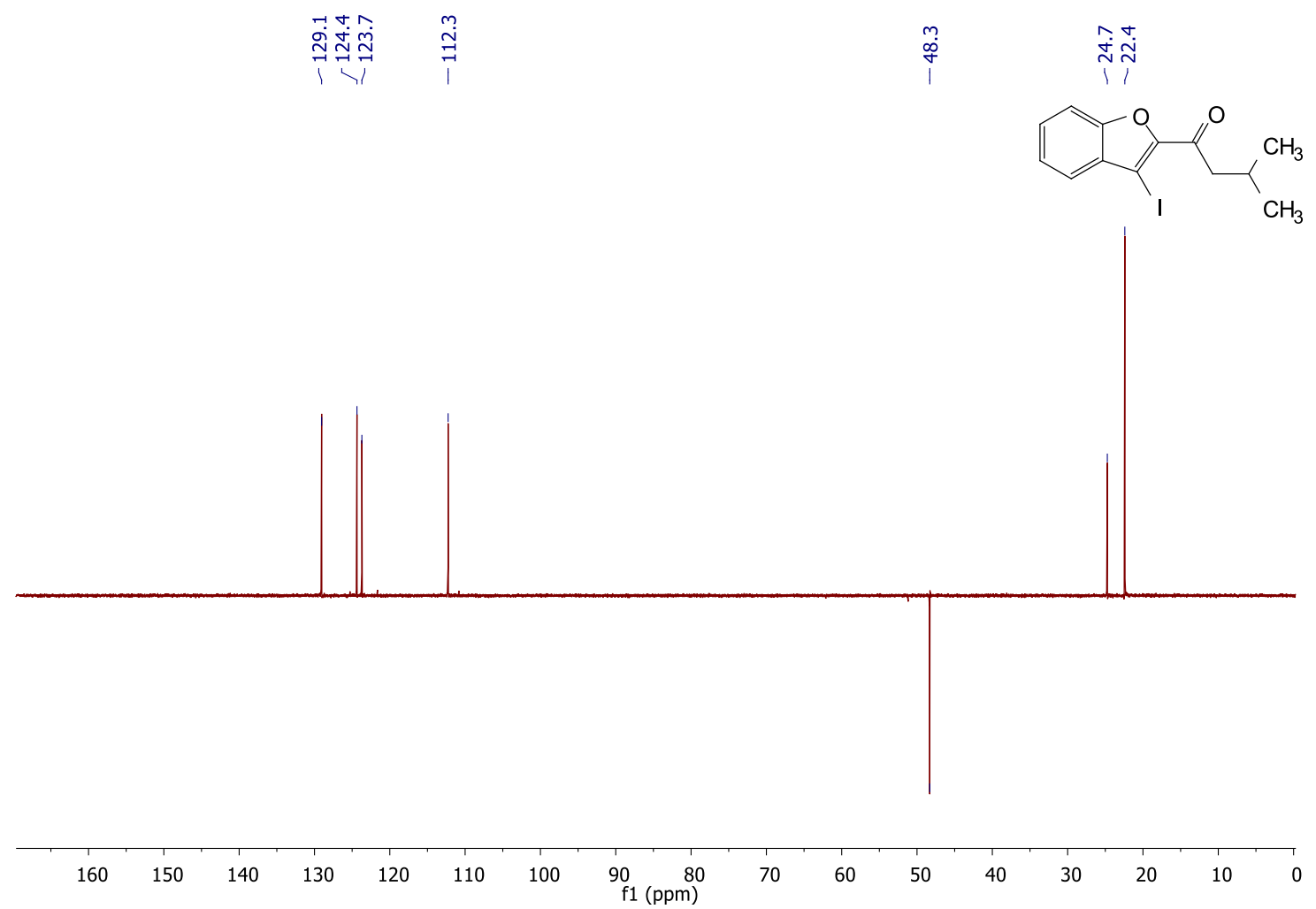

2d ${ }^{1} \mathrm{H}$ NMR spectra $\left(\mathrm{CD}_{2} \mathrm{Cl}_{2}\right)$

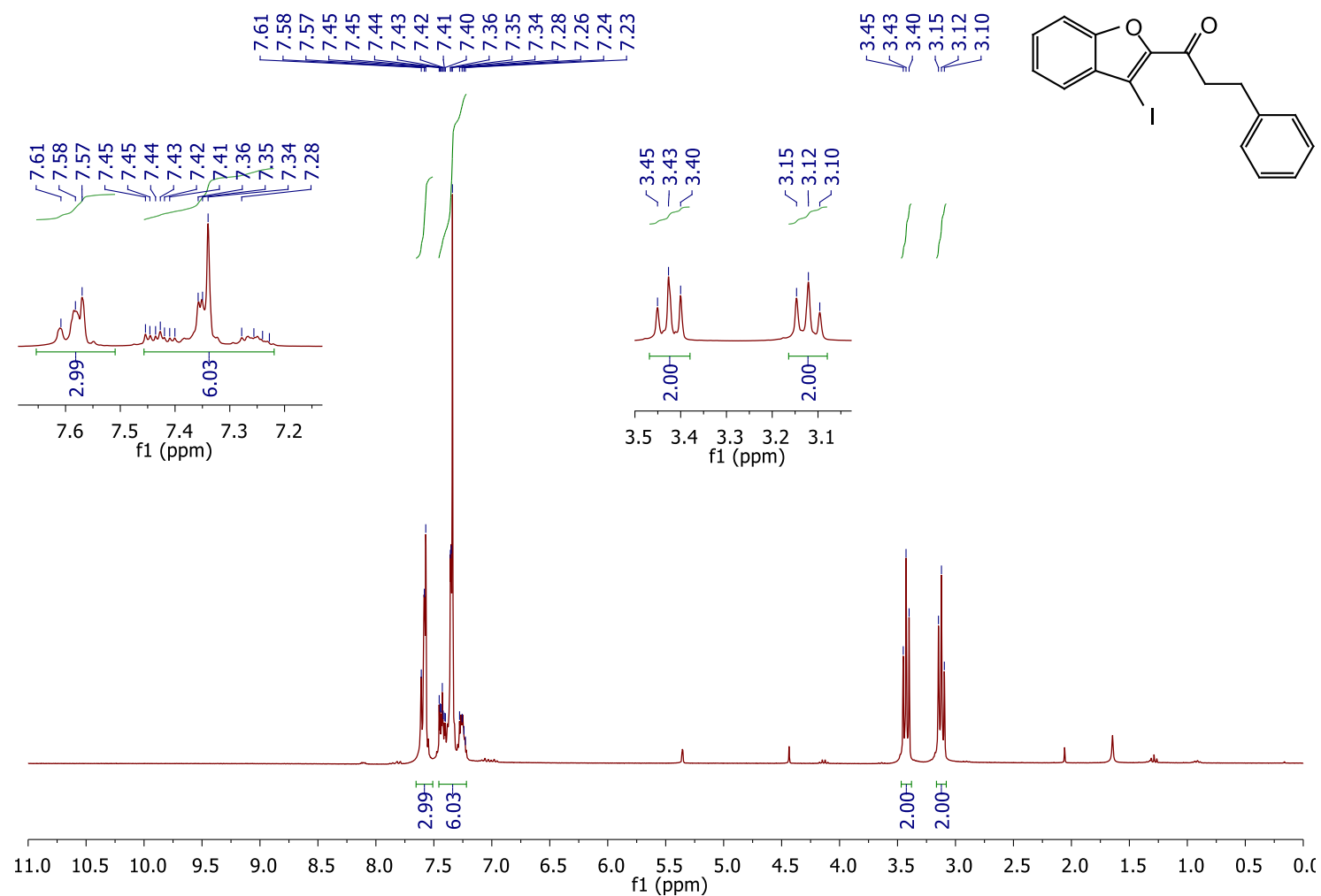




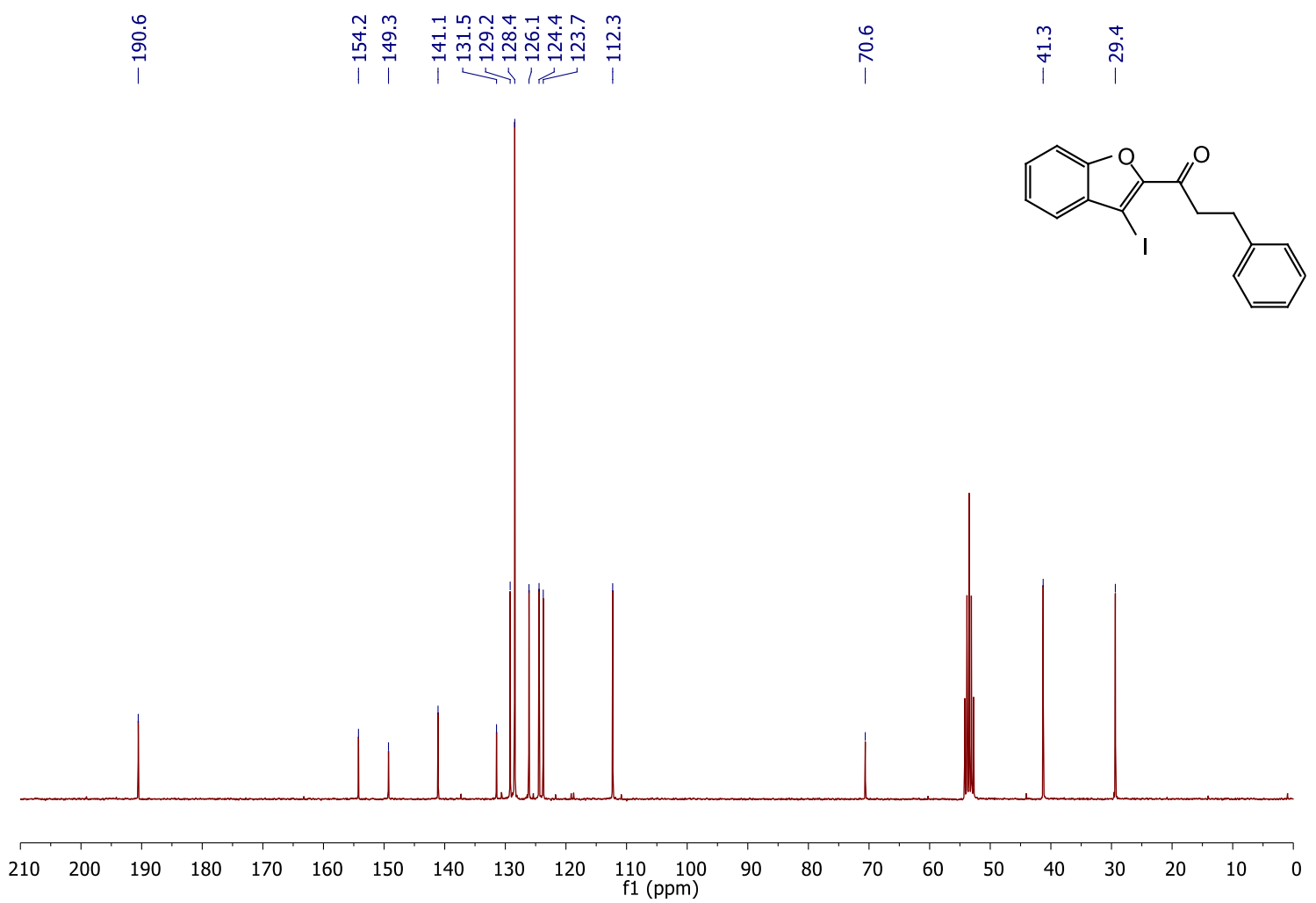

2d DEPT NMR spectra $\left(\mathrm{CD}_{2} \mathrm{Cl}_{2}\right)$

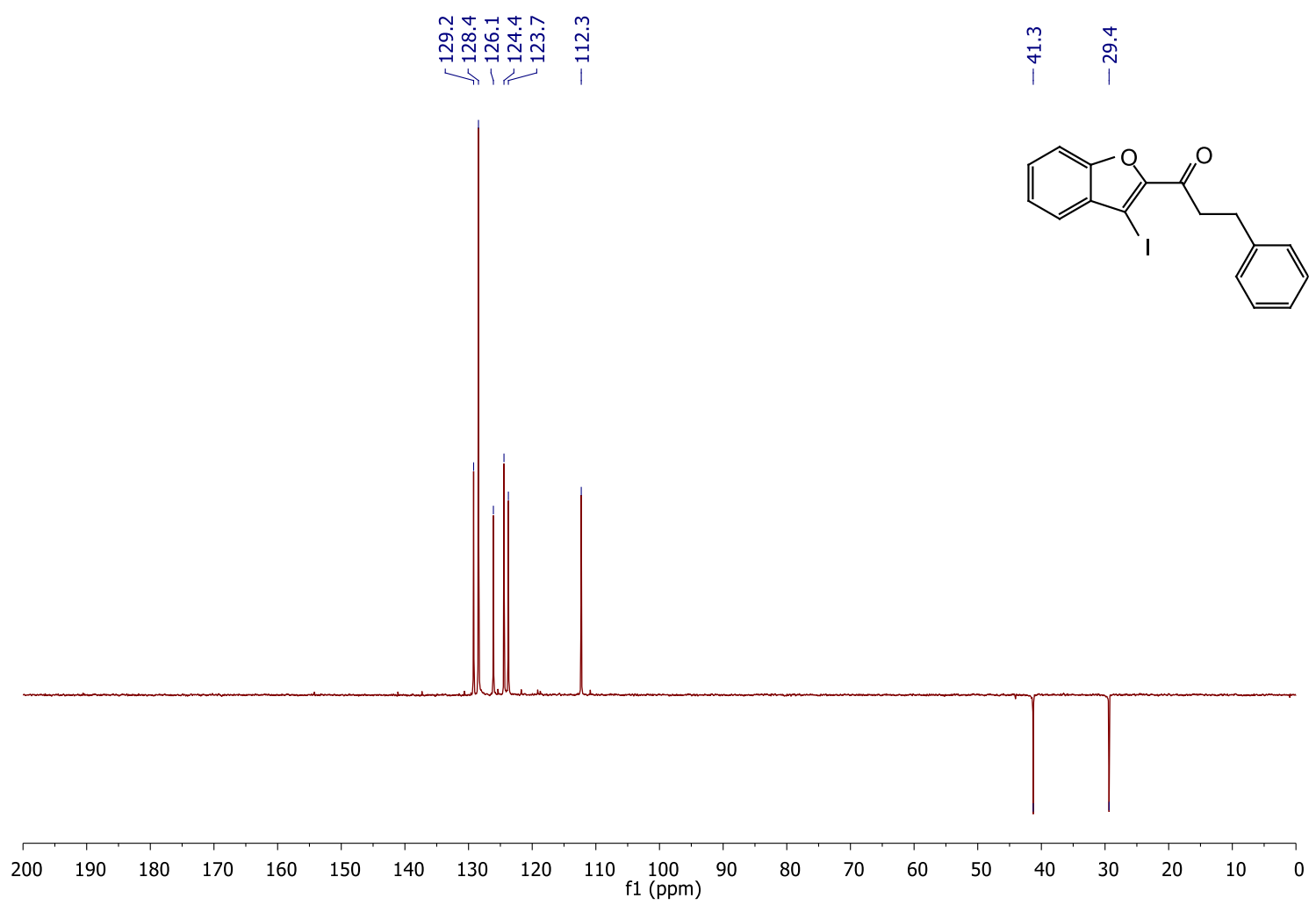




\section{2e $\quad{ }^{1} \mathrm{H}$ NMR spectra $\left(\mathrm{CD}_{2} \mathrm{Cl}_{2}\right)$}

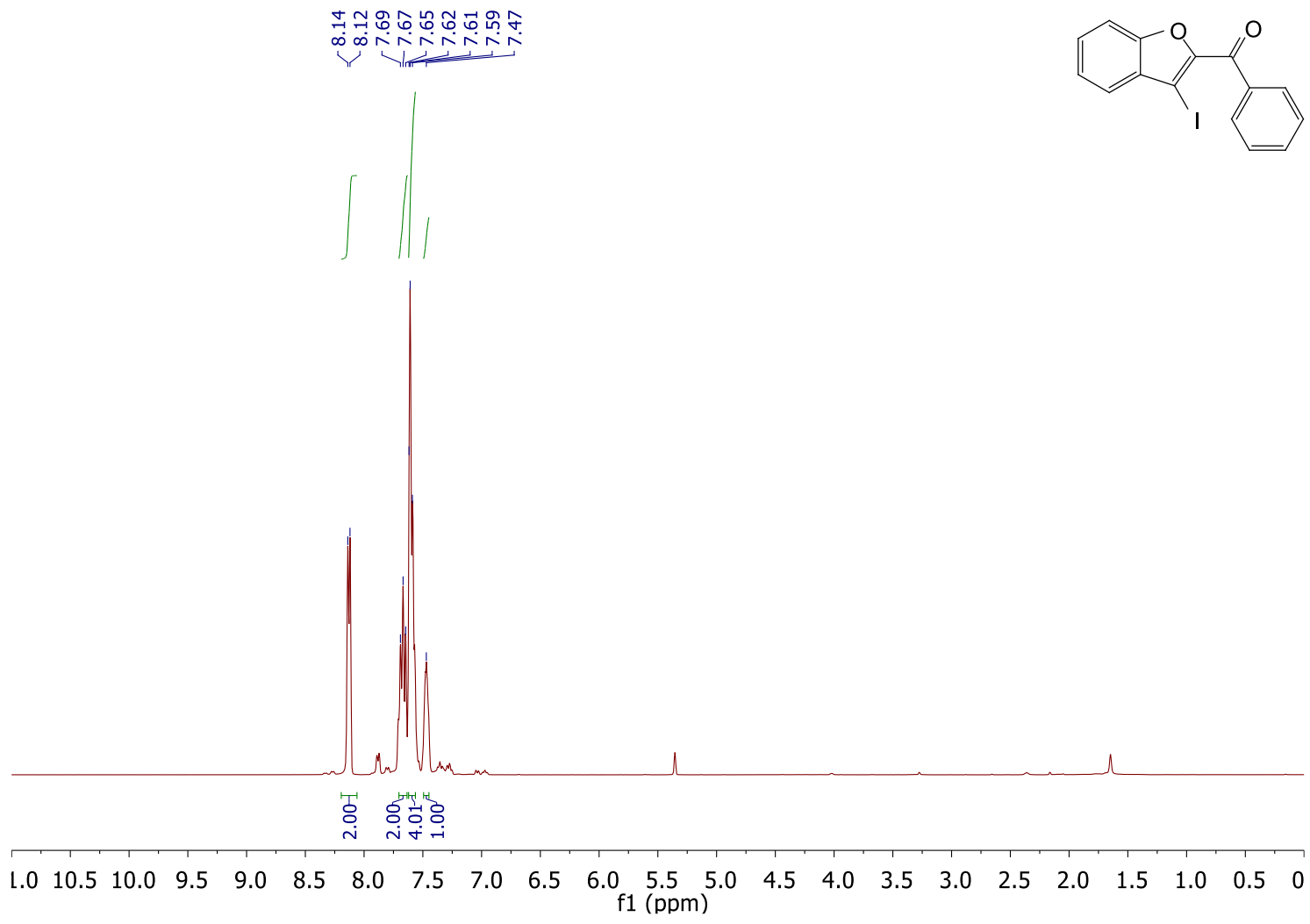

2e $\quad{ }^{13} \mathrm{C}$ NMR spectra $\left(\mathrm{CD}_{2} \mathrm{Cl}_{2}\right)$

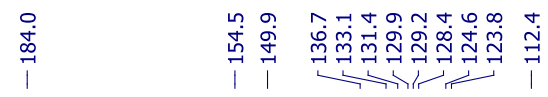
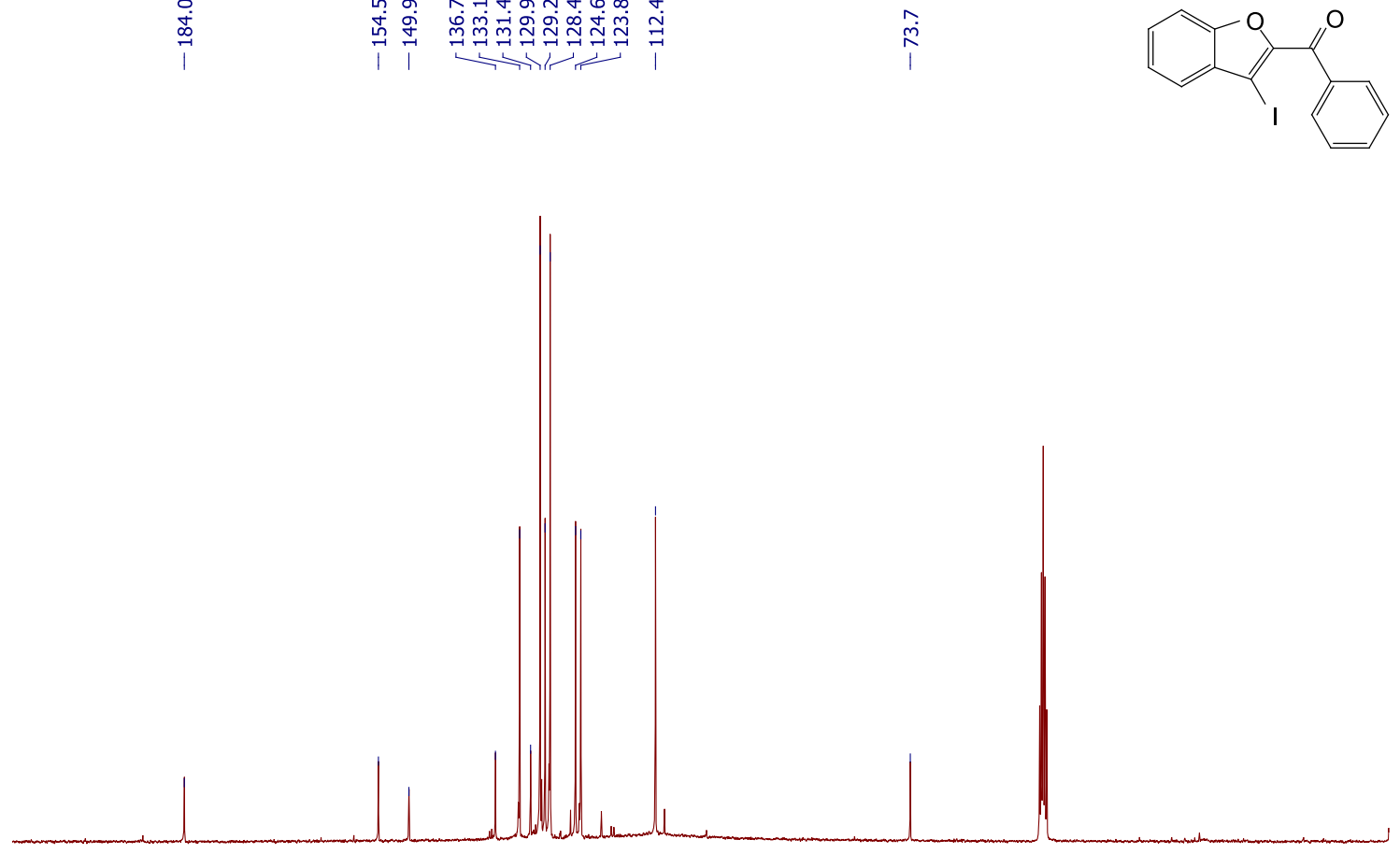

$\begin{array}{lllllllllllllllllllll}10 & 200 & 190 & 180 & 170 & 160 & 150 & 140 & 130 & 120 & 110 & 100 & 90 & 80 & 70 & 60 & 50 & 40 & 30 & 20 & 10\end{array}$ 


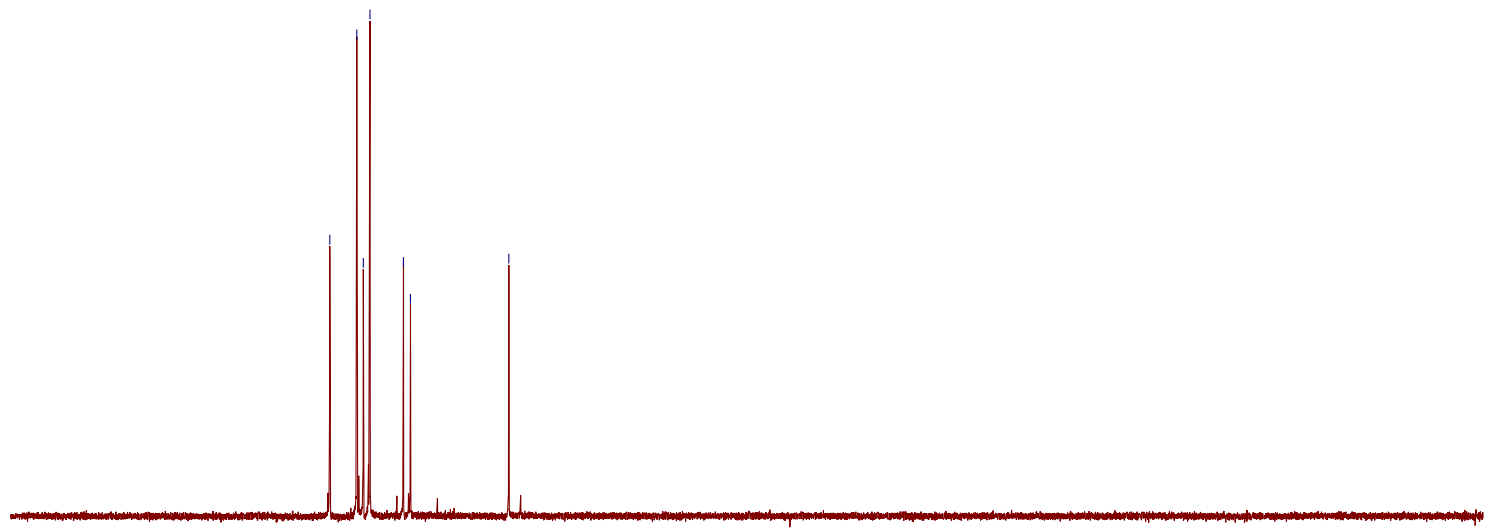

2f ${ }^{1} \mathrm{H}$ NMR spectra $\left(\mathrm{CD}_{2} \mathrm{Cl}_{2}\right)$

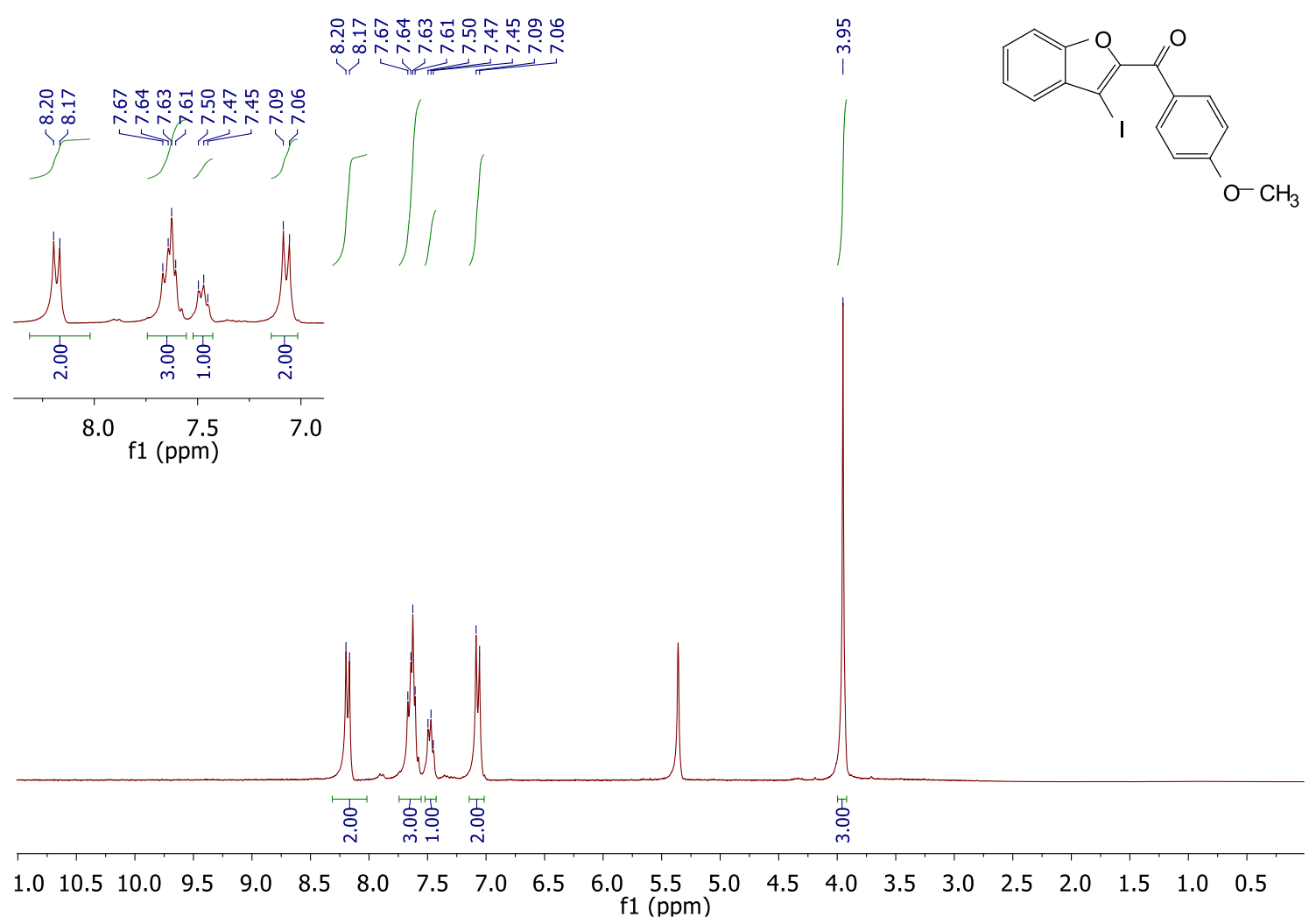


2f ${ }^{13} \mathrm{C}$ NMR spectra $\left(\mathrm{CD}_{2} \mathrm{Cl}_{2}\right)$

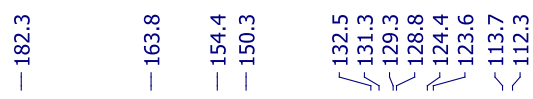
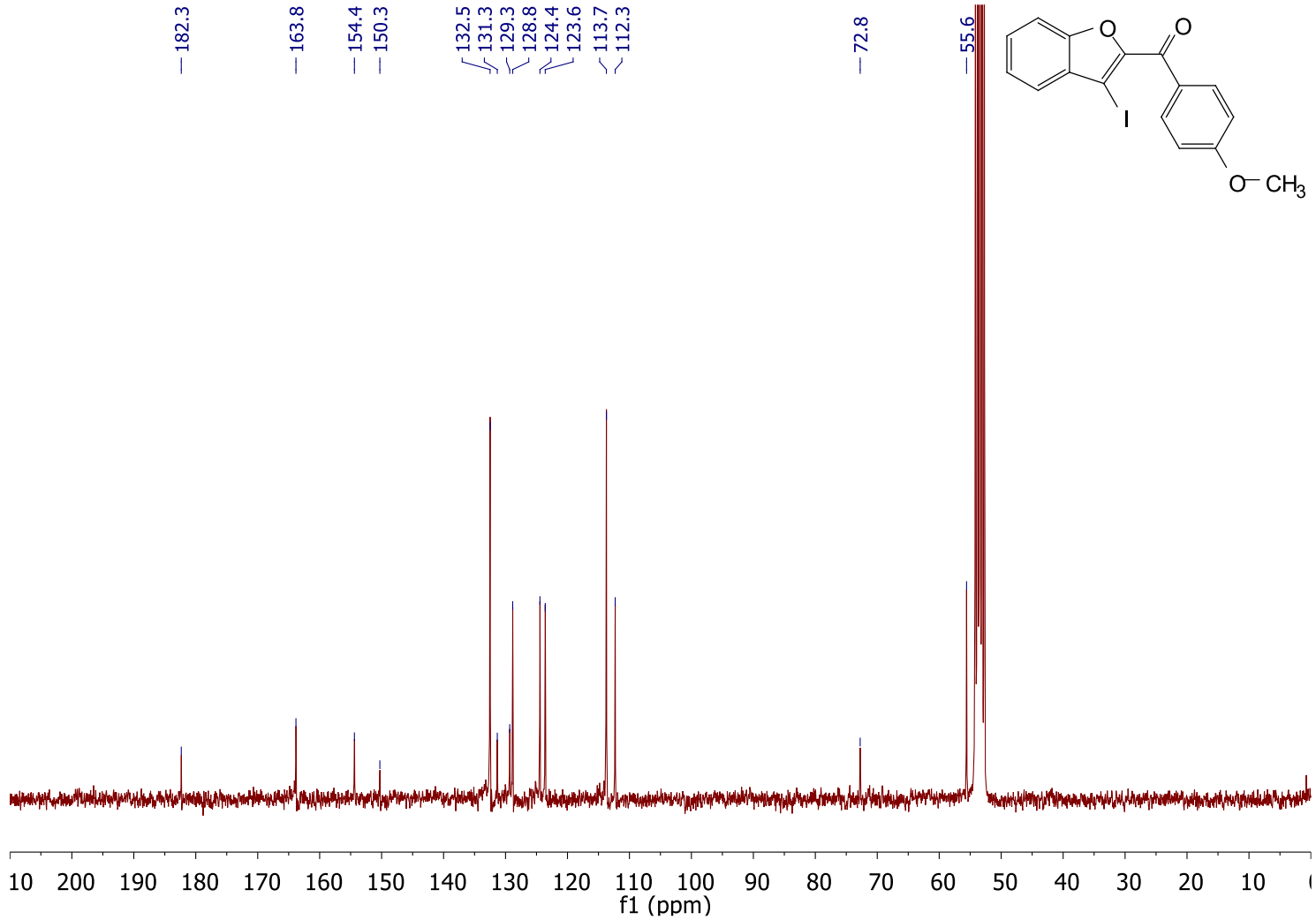

2f DEPT NMR spectra $\left(\mathrm{CD}_{2} \mathrm{Cl}_{2}\right)$

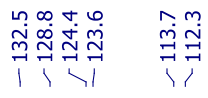
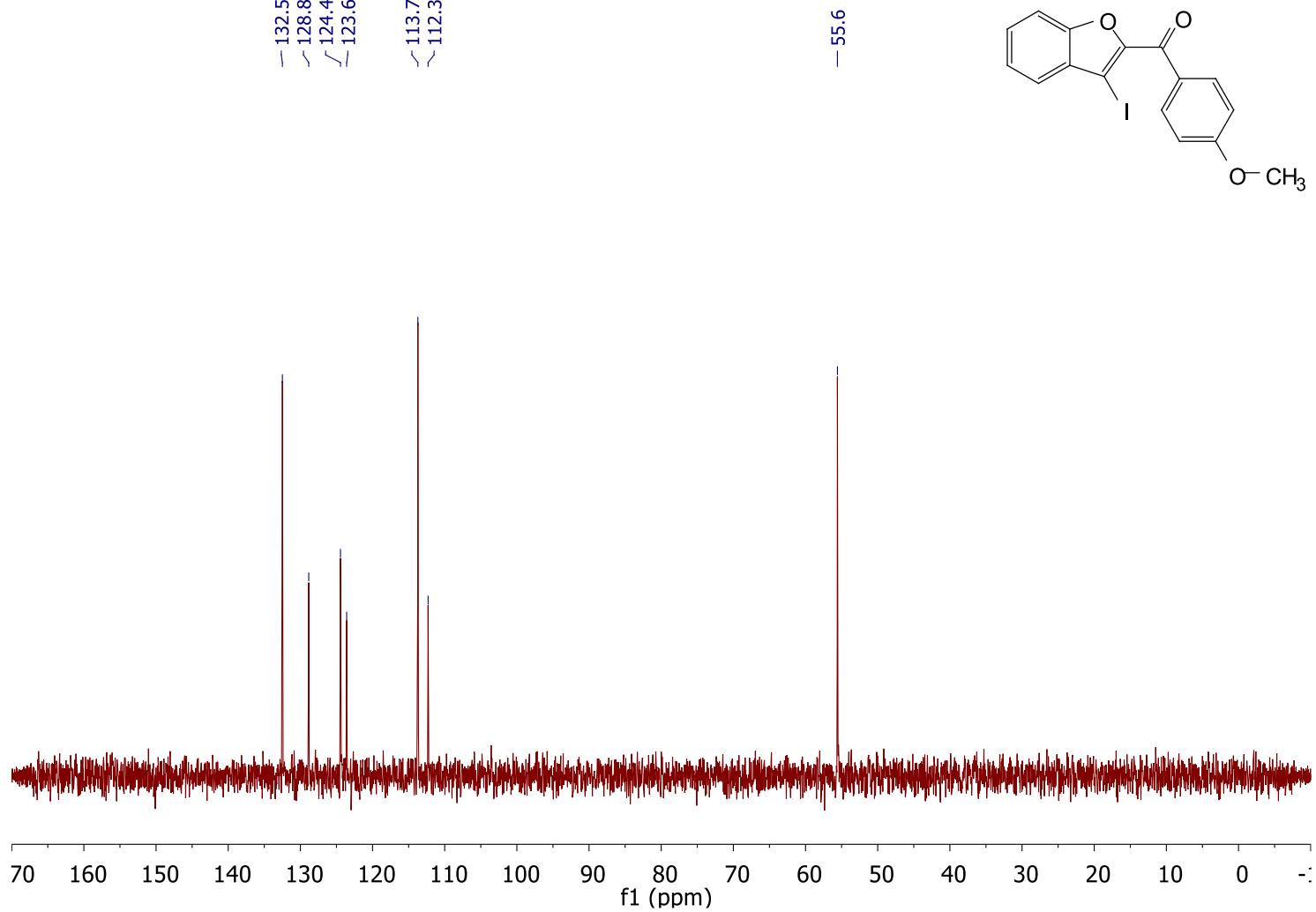


\section{$2 g \quad{ }^{1} \mathrm{H}$ NMR spectra $\left(\mathrm{CD}_{2} \mathrm{Cl}_{2}\right)$}

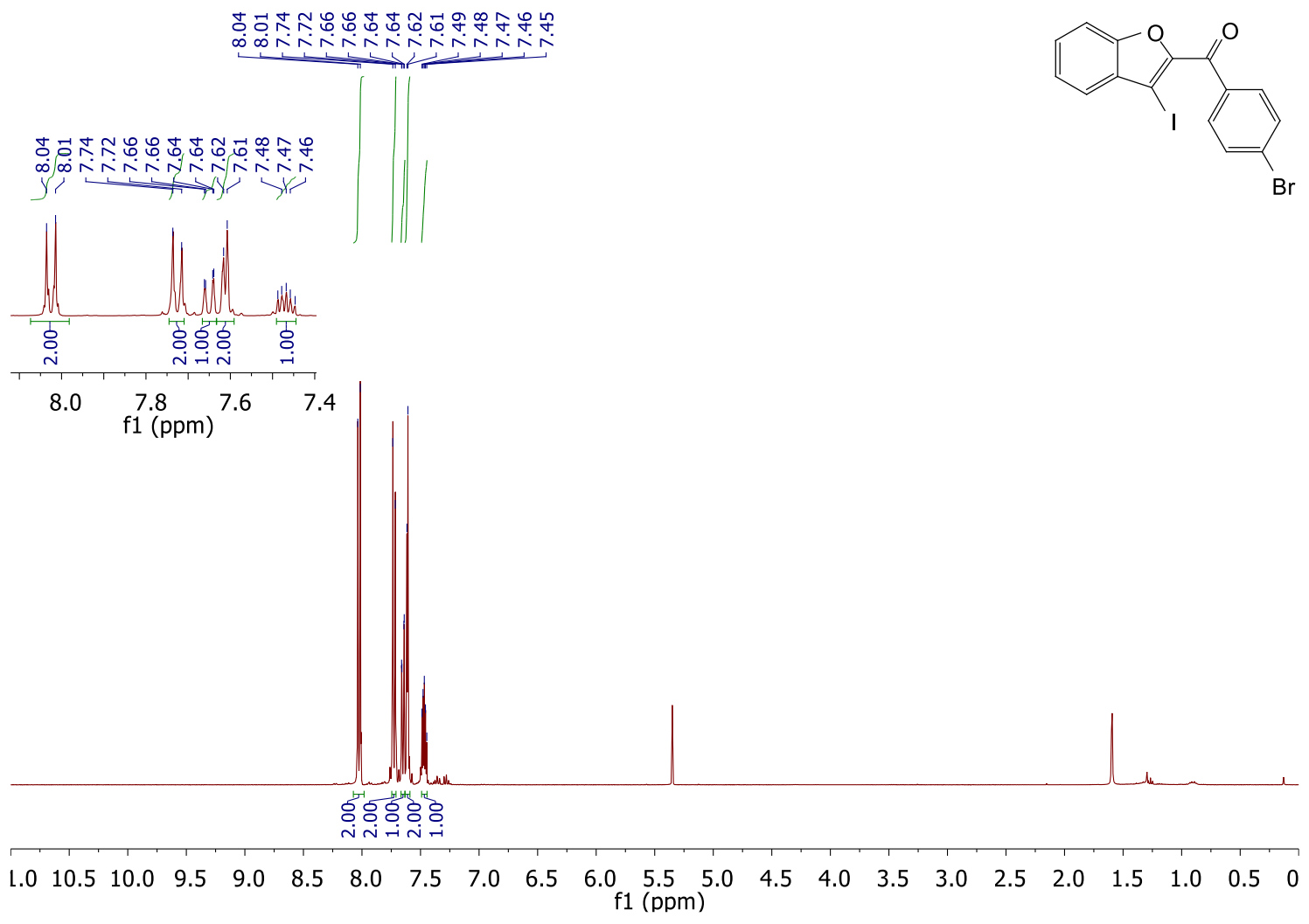

$2 g \quad{ }^{13} \mathrm{C}$ NMR spectra $\left(\mathrm{CD}_{2} \mathrm{Cl}_{2}\right)$
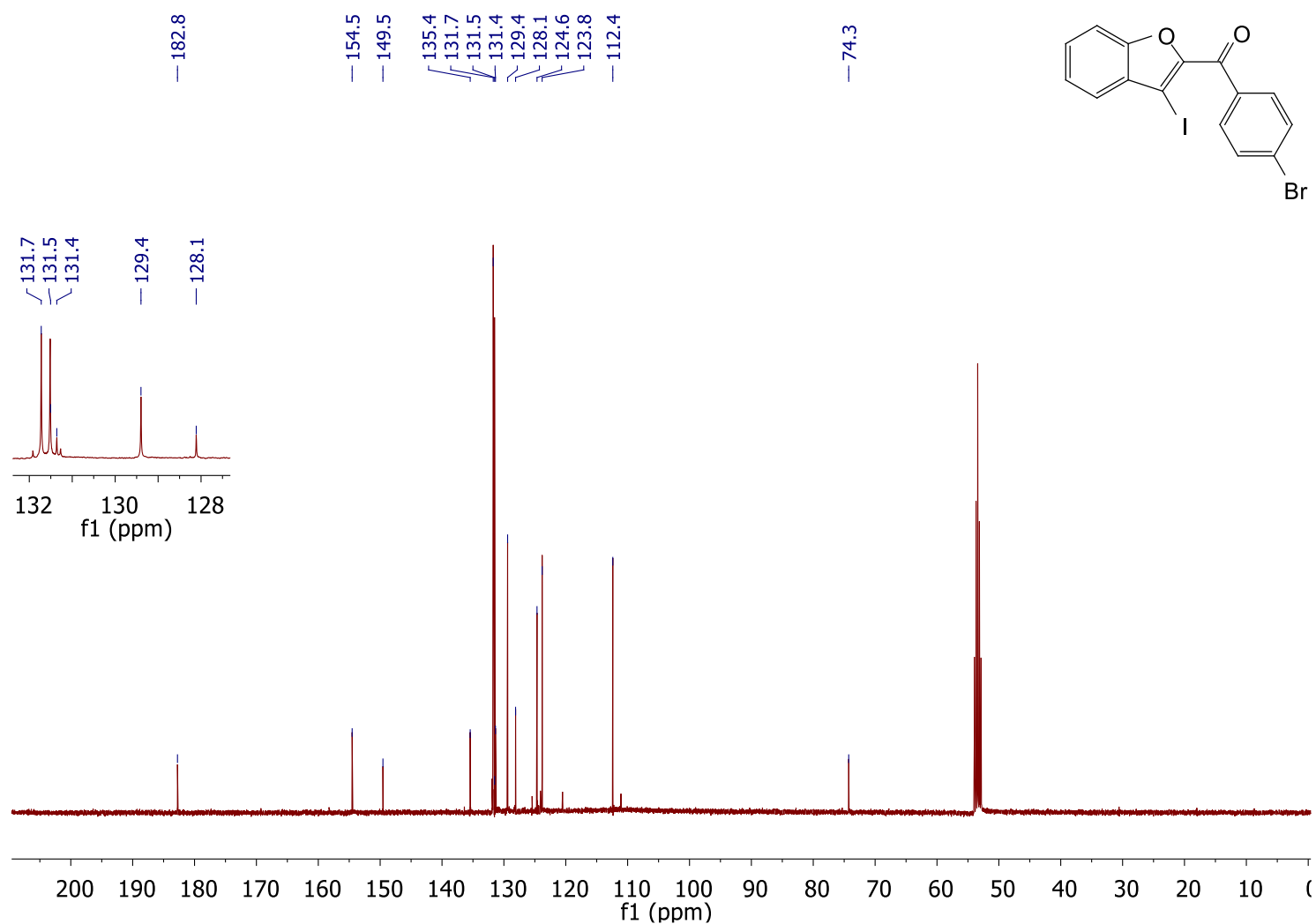
$2 \mathrm{~h} \quad{ }^{1} \mathrm{H}$ NMR spectra $\left(\mathrm{CD}_{2} \mathrm{Cl}_{2}\right)$

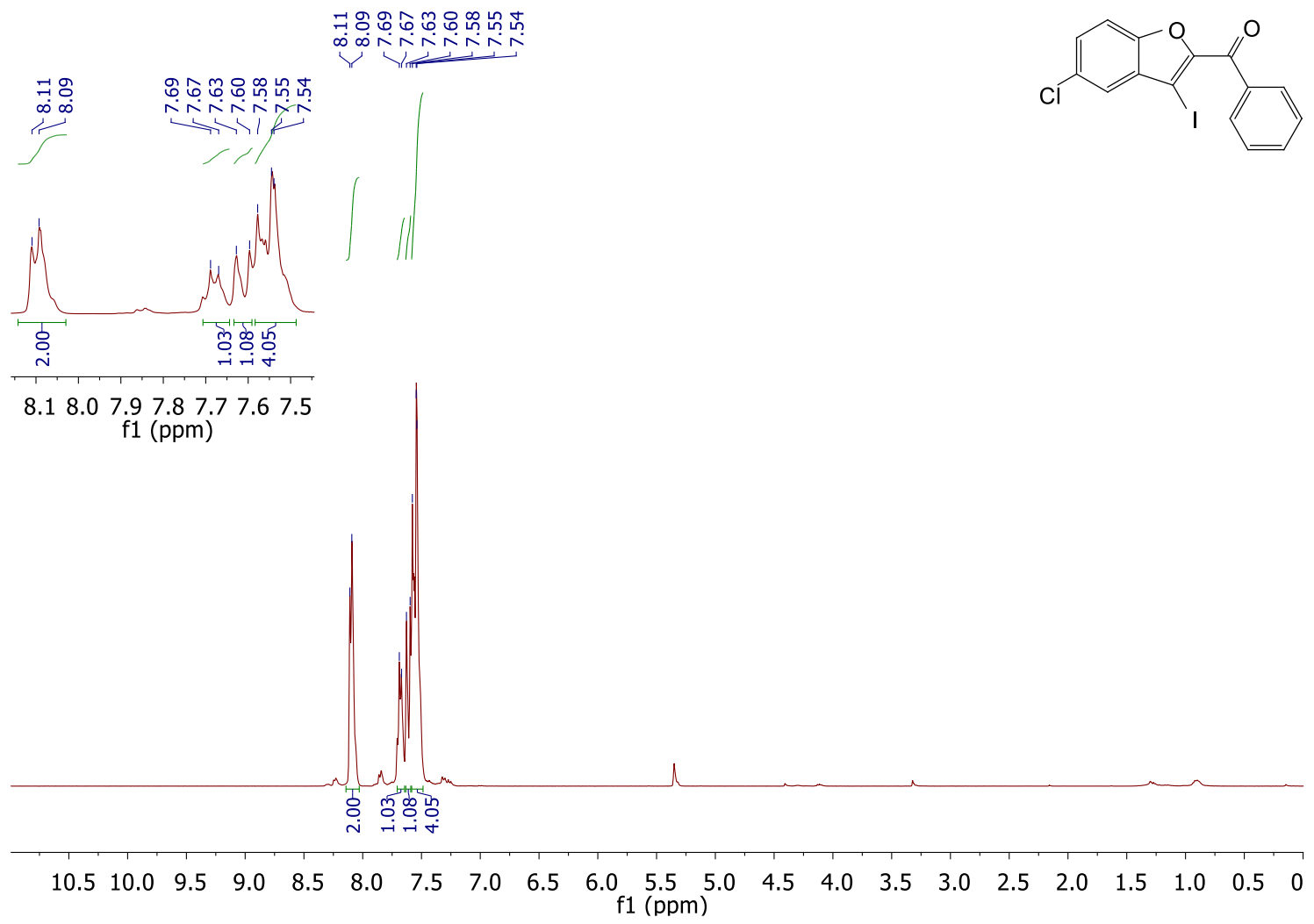

2h $\quad{ }^{13} \mathrm{C}$ NMR spectra $\left(\mathrm{CD}_{2} \mathrm{Cl}_{2}\right)$

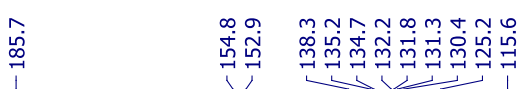

幽离

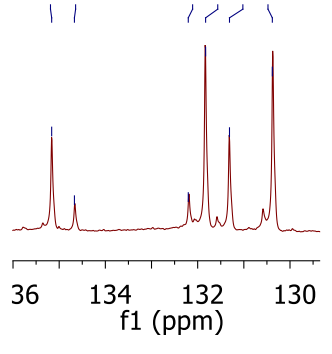

$\stackrel{\substack{+i}}{i}$
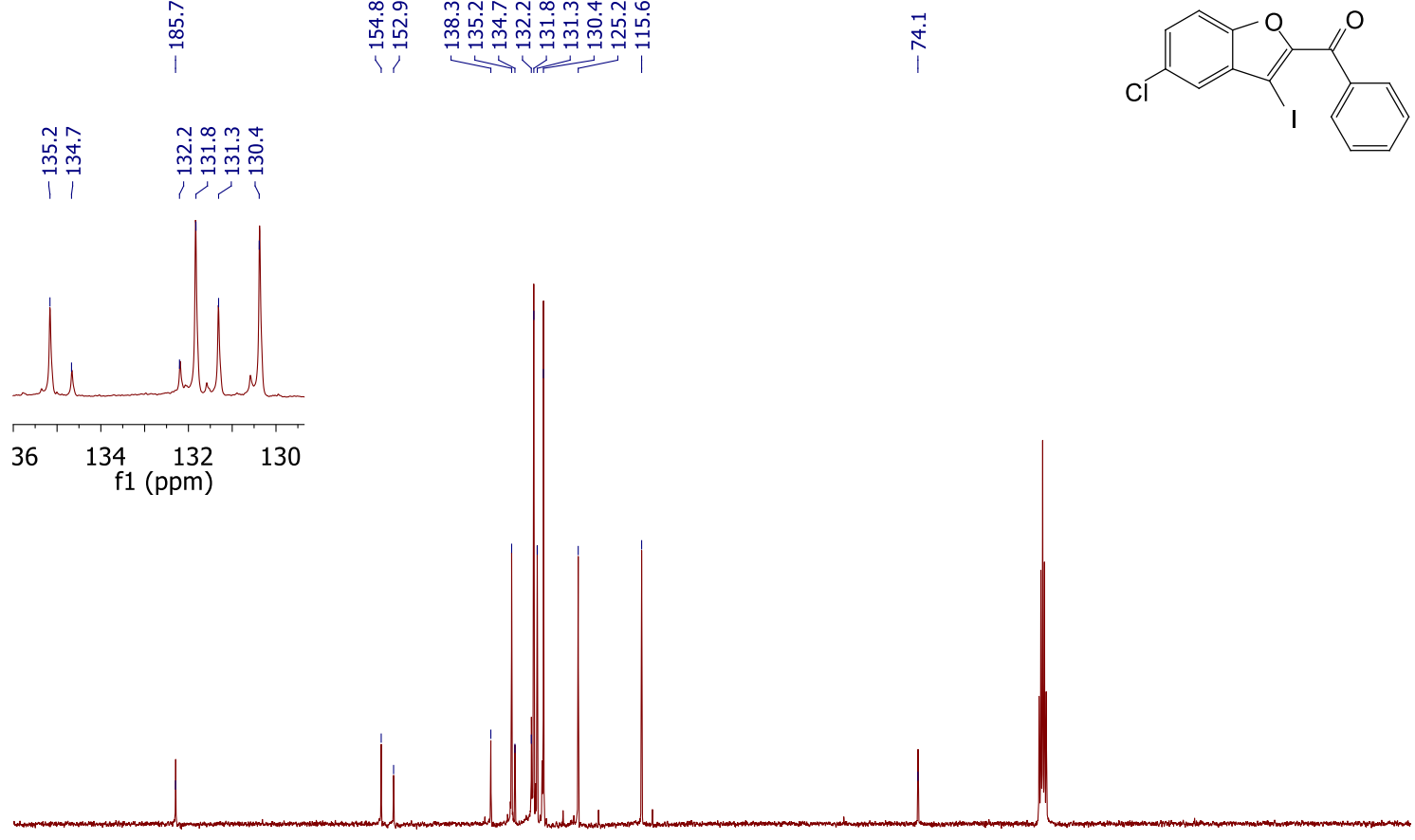

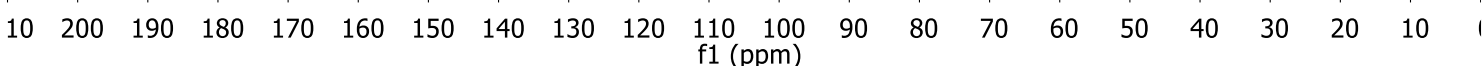




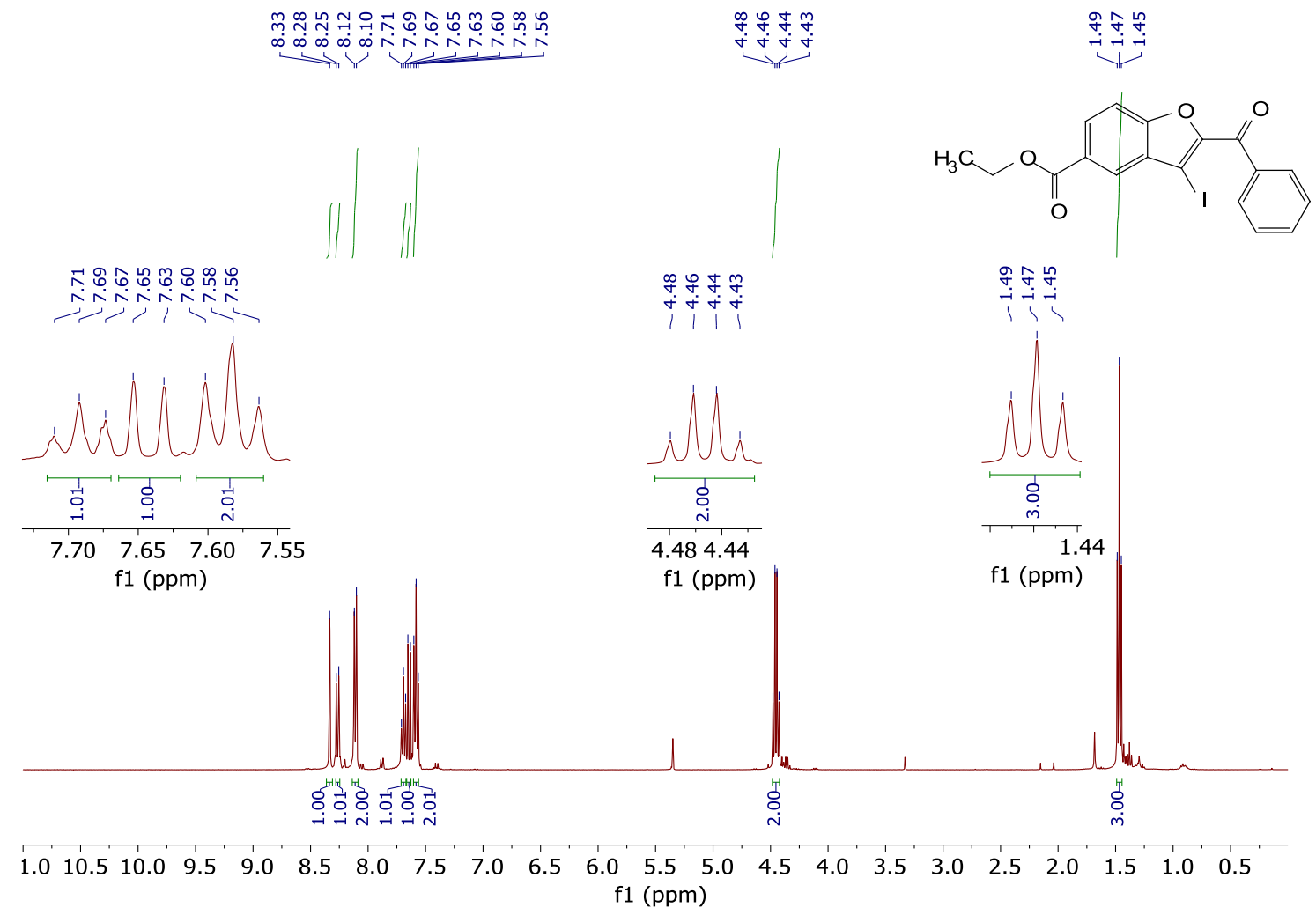

$2 \mathrm{i} \quad{ }^{13} \mathrm{C}$ NMR spectra $\left(\mathrm{CD}_{2} \mathrm{Cl}_{2}\right)$

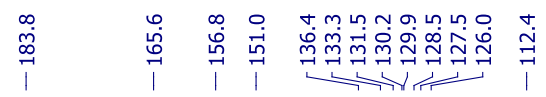

$\stackrel{\infty}{\stackrel{m}{i}} \underset{i}{\stackrel{m}{i}} \stackrel{\stackrel{\sim}{\sim}}{i}$
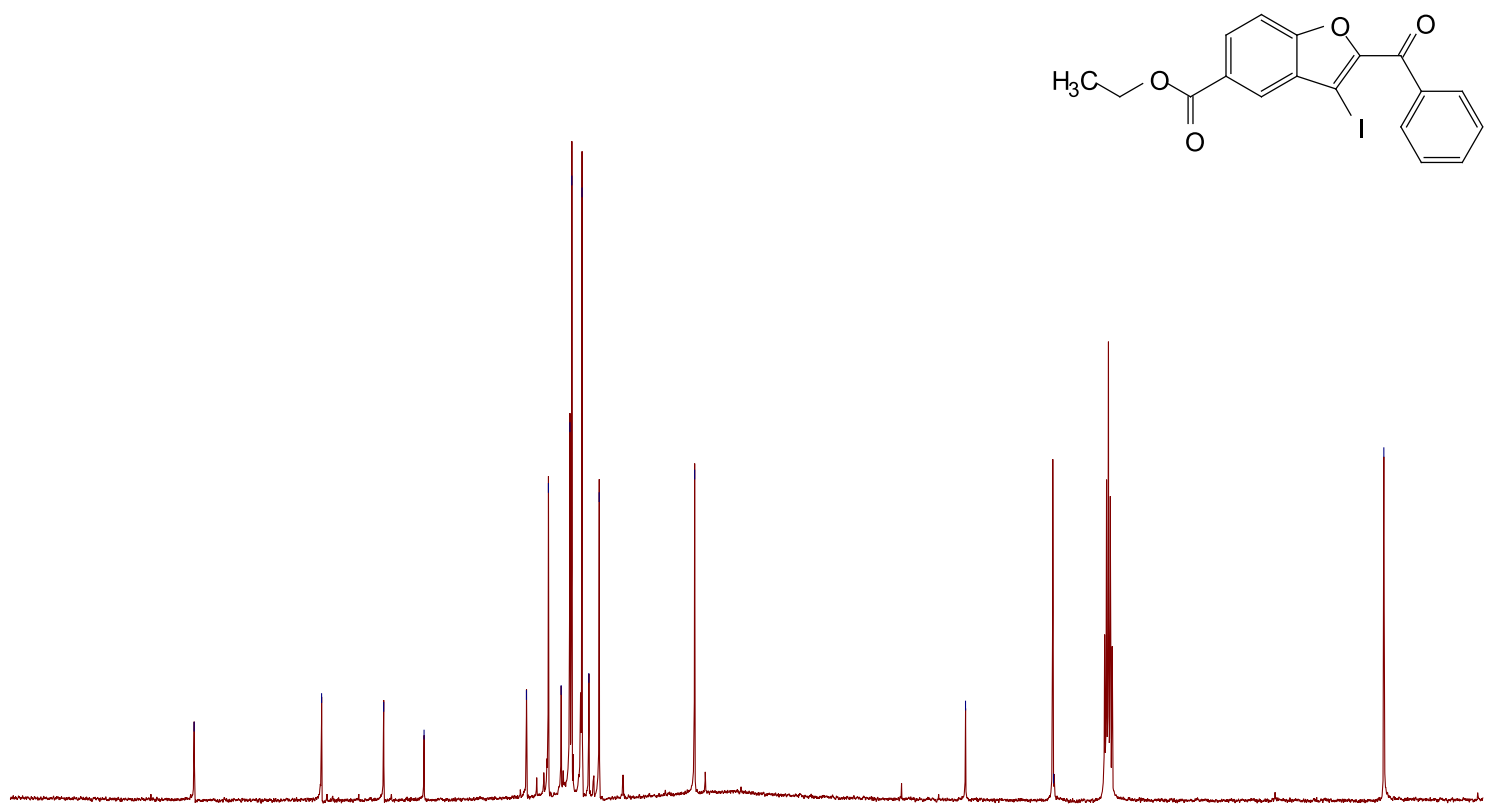

$\begin{array}{lllllllllllllllllllll}10 & 200 & 190 & 180 & 170 & 160 & 150 & 140 & 130 & 120 & \begin{array}{c}110 \\ \mathrm{f} 1(\mathrm{ppm})\end{array} & 90 & 80 & 70 & 60 & 50 & 40 & 30 & 20 & 10\end{array}$ 


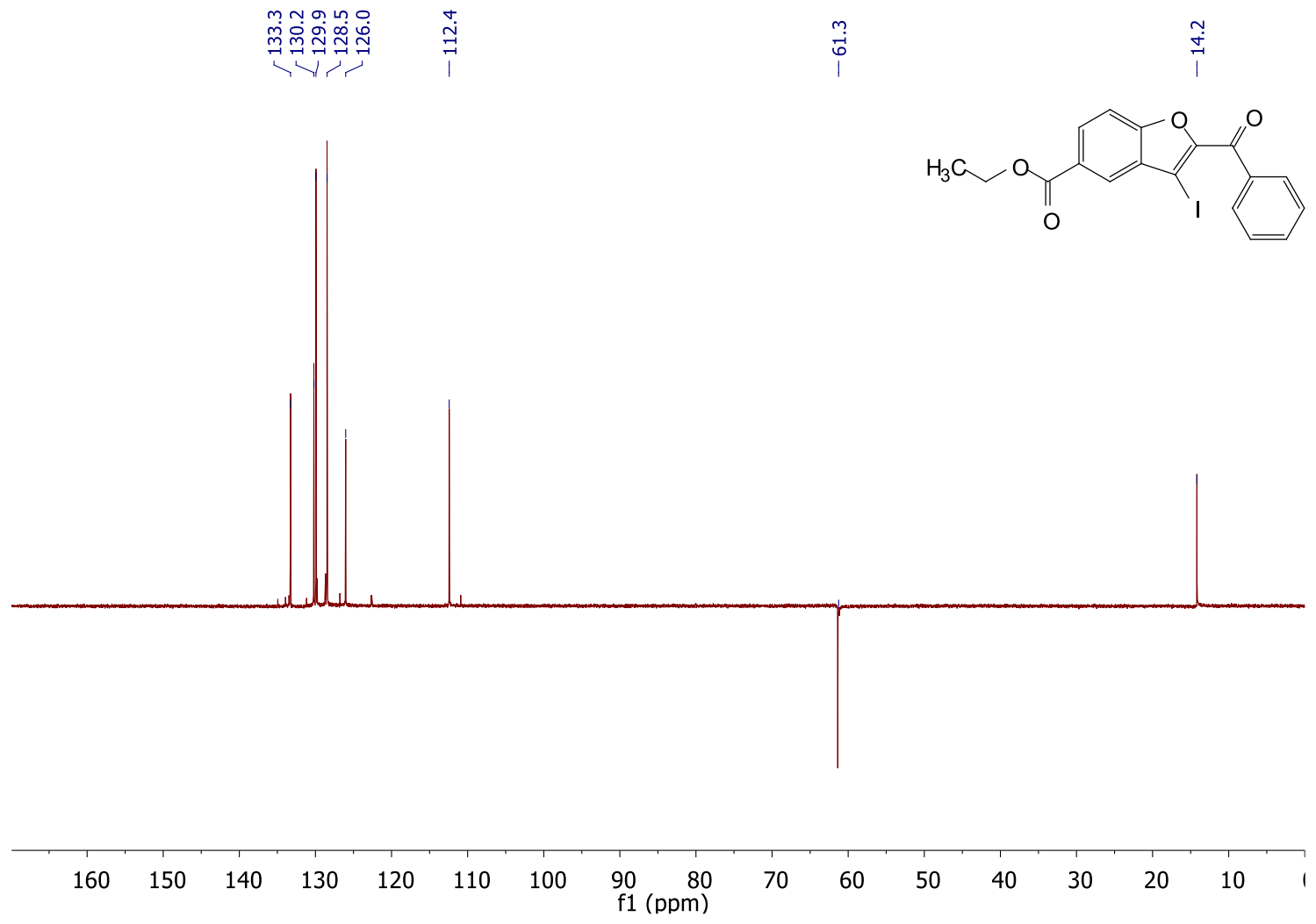

2j ${ }^{1} \mathrm{H}$ NMR spectra $\left(\mathrm{CD}_{2} \mathrm{Cl}_{2}\right)$

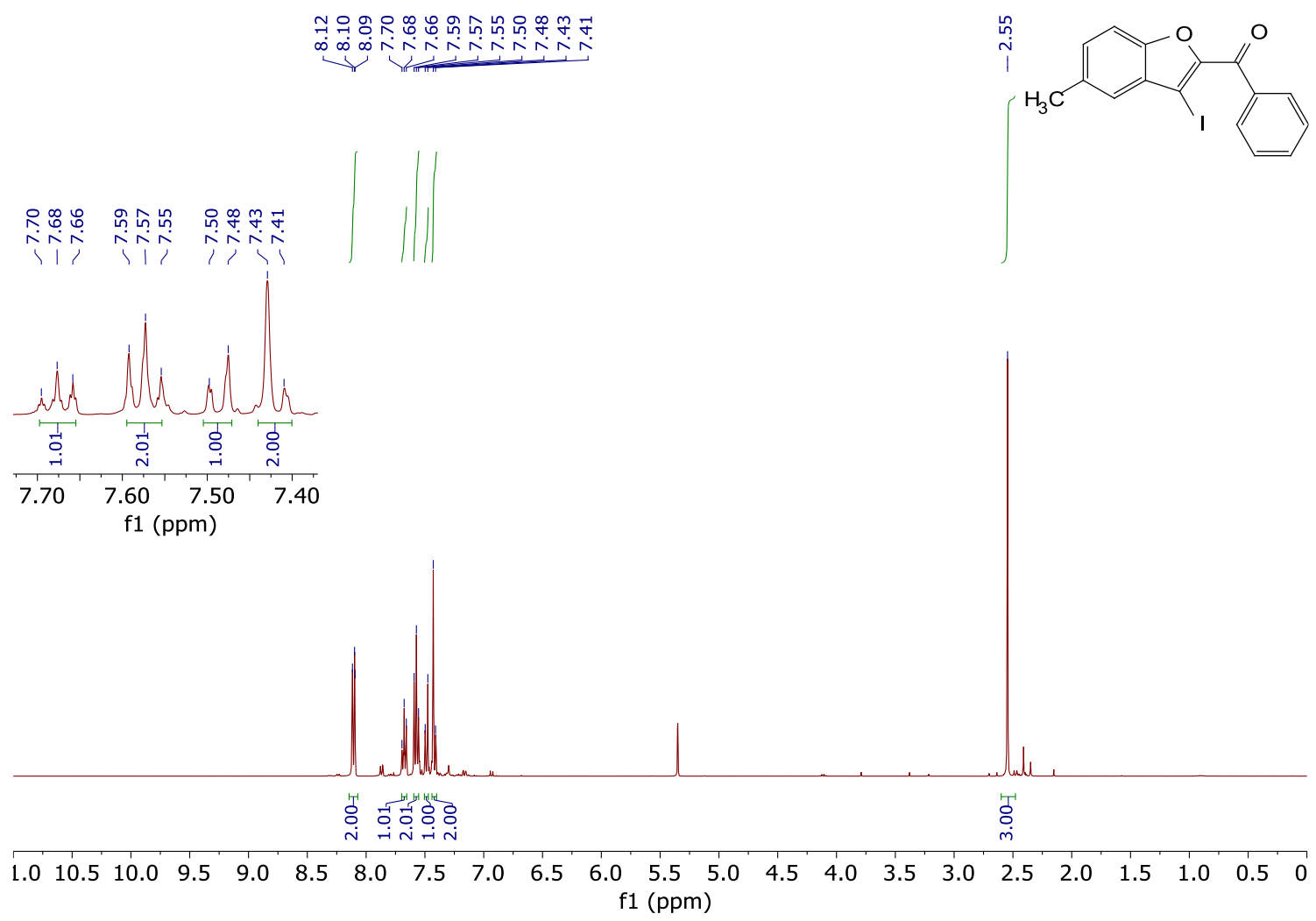


2j ${ }^{13} \mathrm{C}$ NMR spectra $\left(\mathrm{CD}_{2} \mathrm{Cl}_{2}\right)$

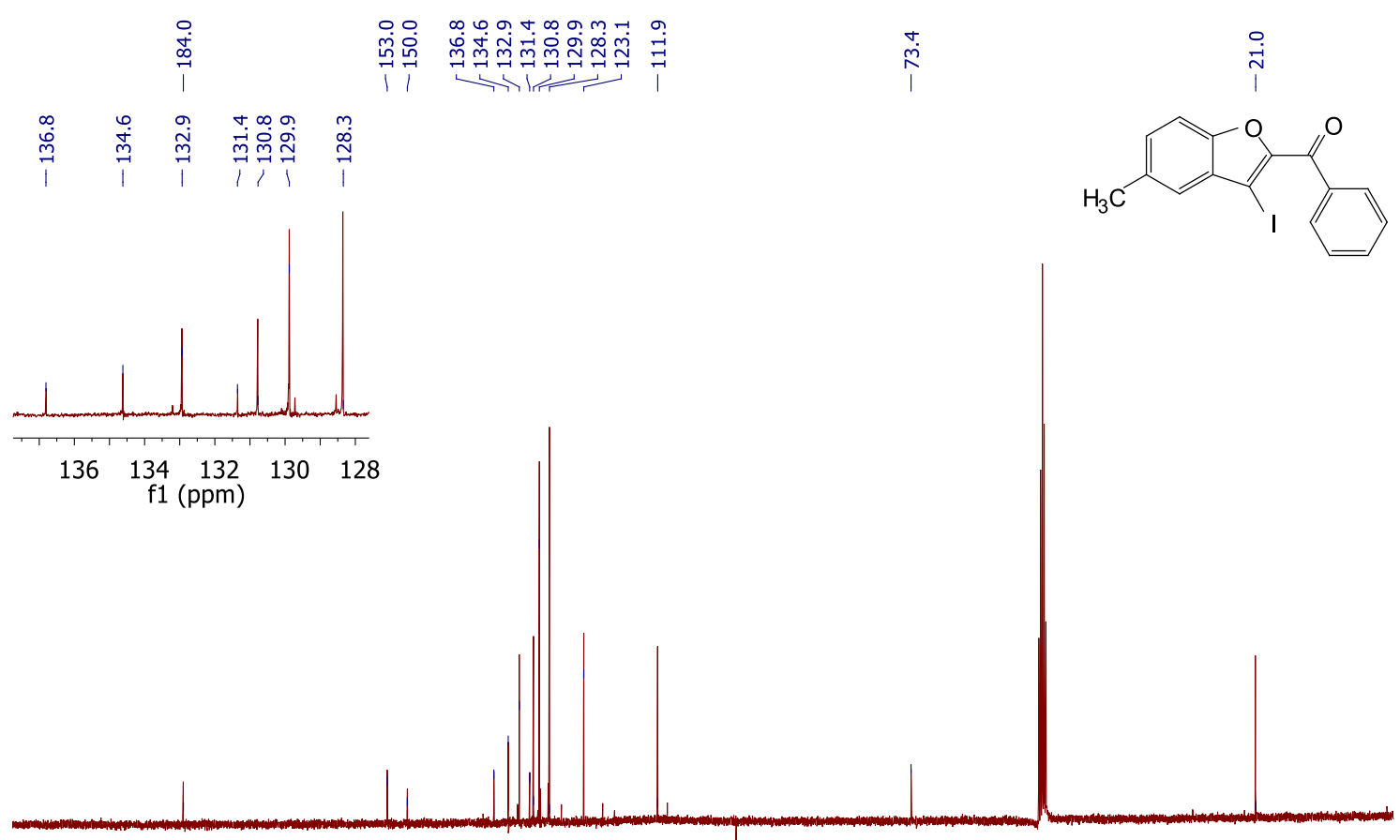

$\begin{array}{llllllllllllllllllllll}10 & 200 & 190 & 180 & 170 & 160 & 150 & 140 & 130 & 120 & \begin{array}{c}110(\mathrm{ppm}) \\ \mathrm{f}(\mathrm{pm})\end{array} & 90 & 80 & 70 & 60 & 50 & 40 & 30 & 20 & 10 & 1\end{array}$

2j DEPT NMR spectra $\left(\mathrm{CD}_{2} \mathrm{Cl}_{2}\right)$

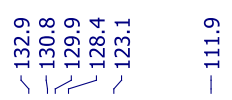
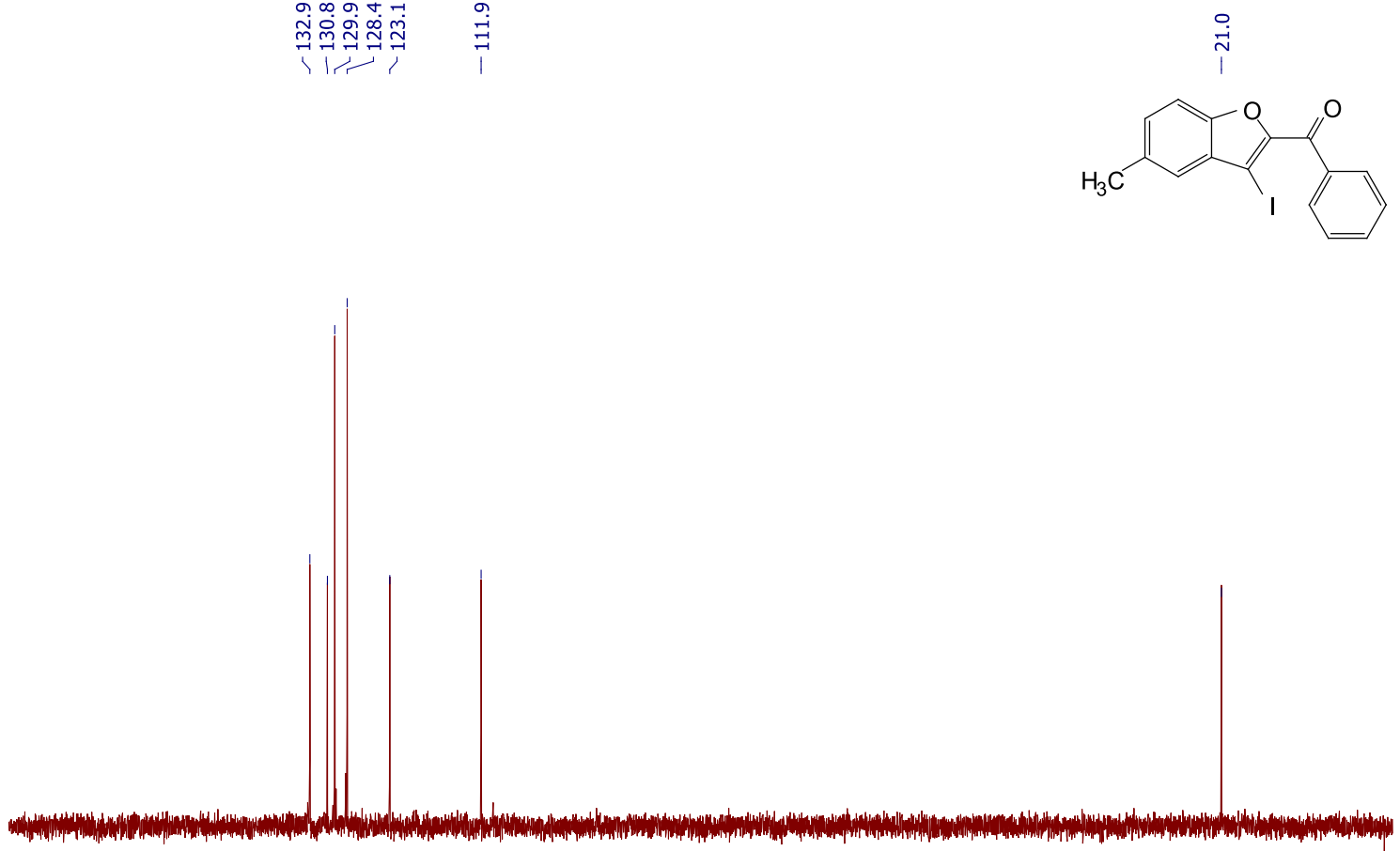

160

$150 \quad 140$

130

120

$110 \quad 100$

$90 \quad 80$

70

60

50

$\begin{array}{lll}40 & 30 \quad 20\end{array}$

10 


\section{2k ${ }^{1} \mathrm{H}$ NMR spectra $\left(\mathrm{CD}_{2} \mathrm{Cl}_{2}\right)$}

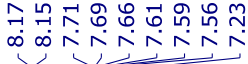

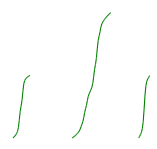

กั่ำ
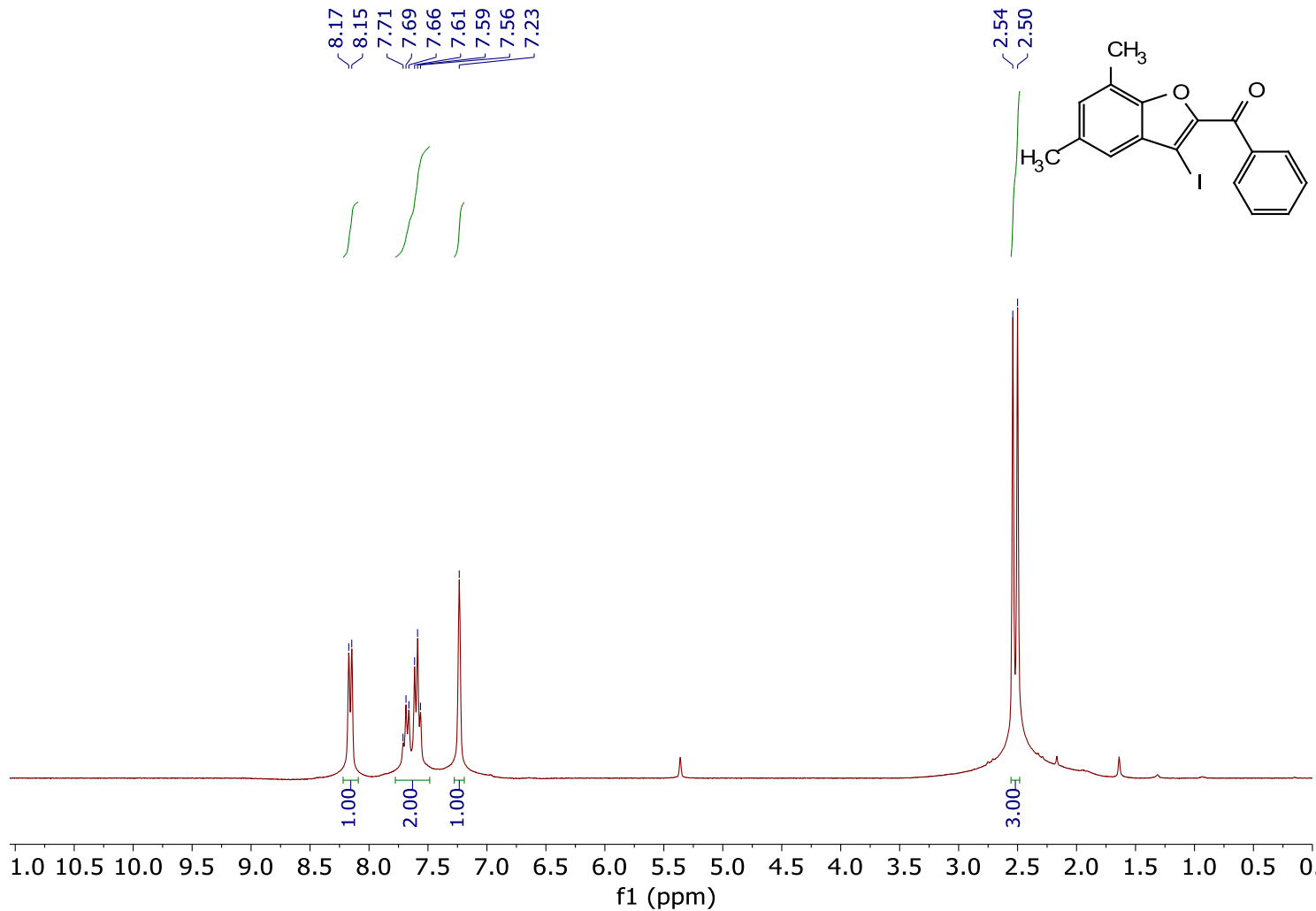

2k ${ }^{13} \mathrm{C}$ NMR spectra $\left(\mathrm{CD}_{2} \mathrm{Cl}_{2}\right)$

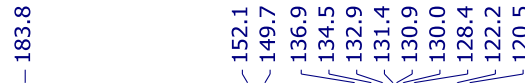

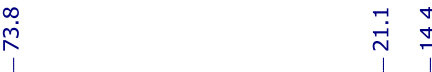

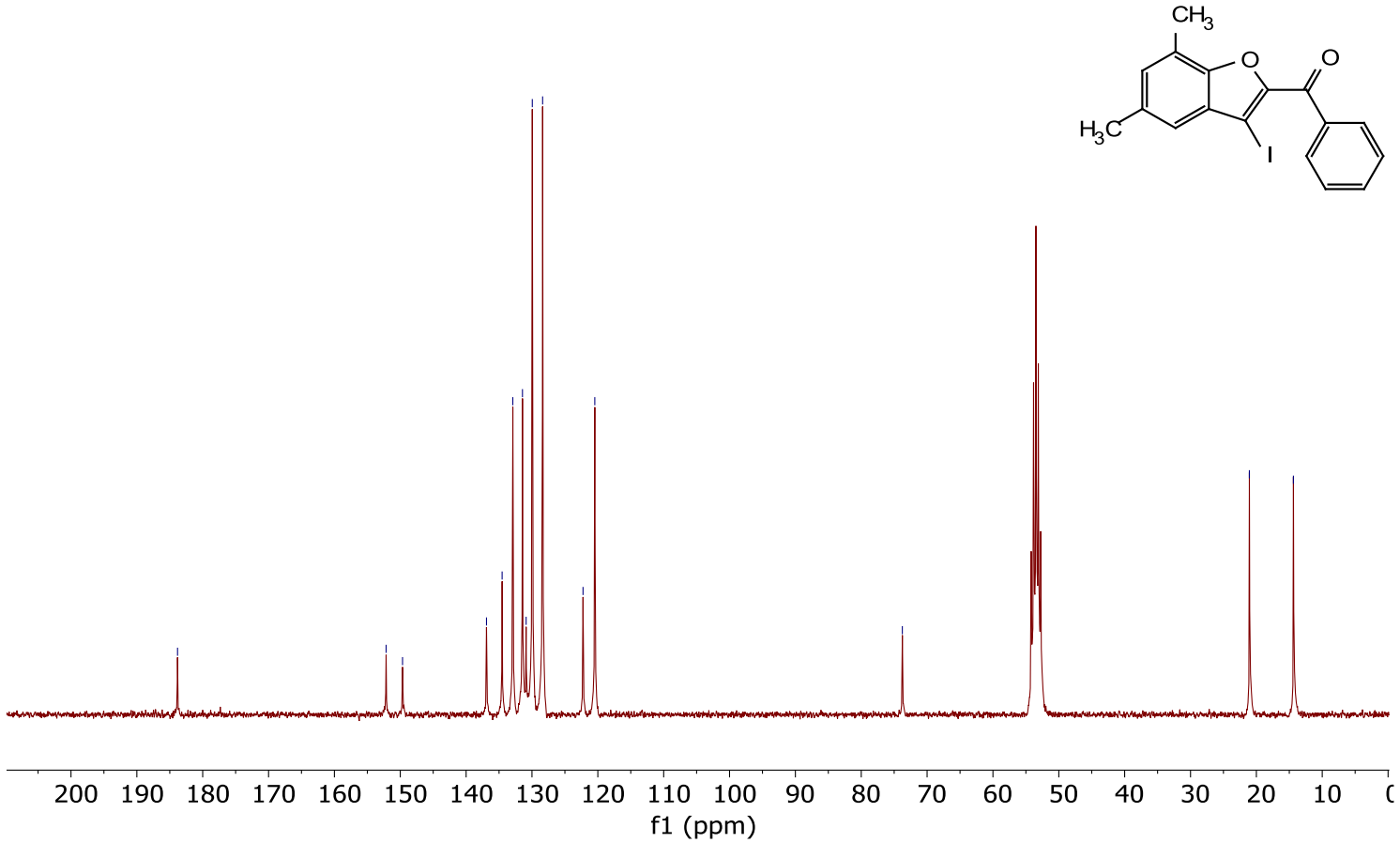



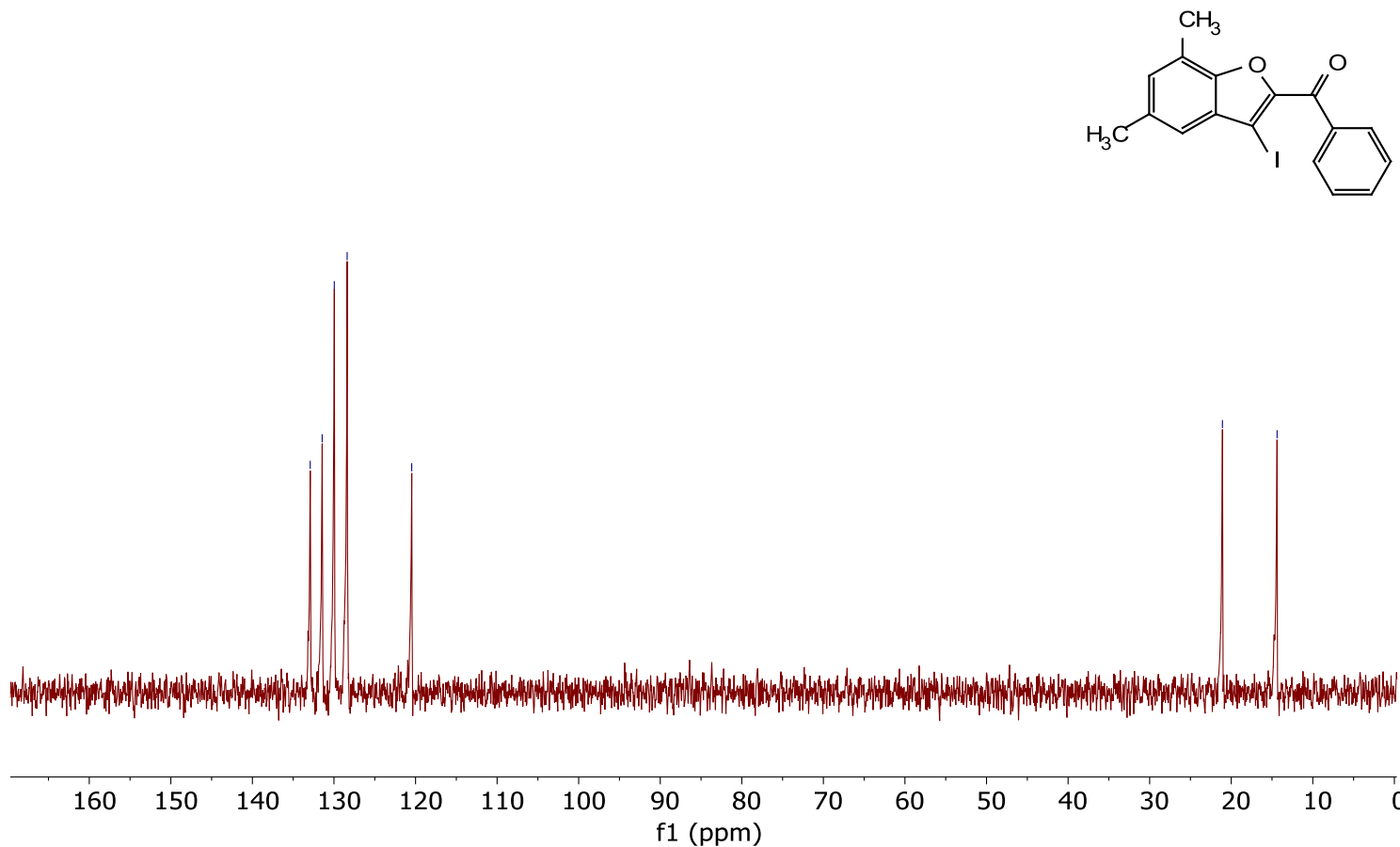

\section{I ${ }^{1} \mathrm{H}$ NMR spectra $\left(\mathrm{CD}_{2} \mathrm{Cl}_{2}\right)$}

مo

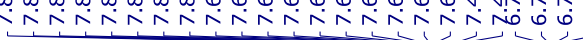

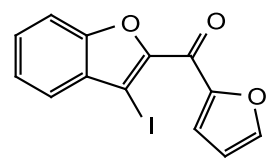

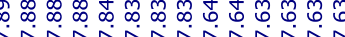

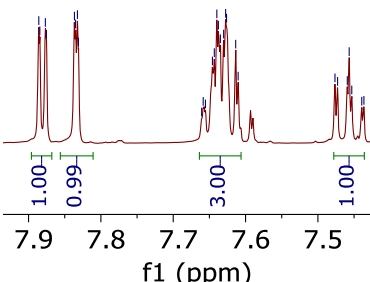

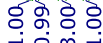

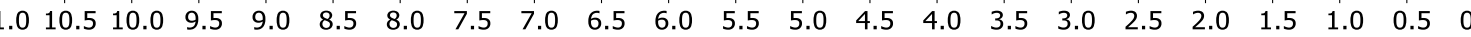
f1 (ppm) 
2I ${ }^{13} \mathrm{C}$ NMR spectra $\left(\mathrm{CD}_{2} \mathrm{Cl}_{2}\right)$

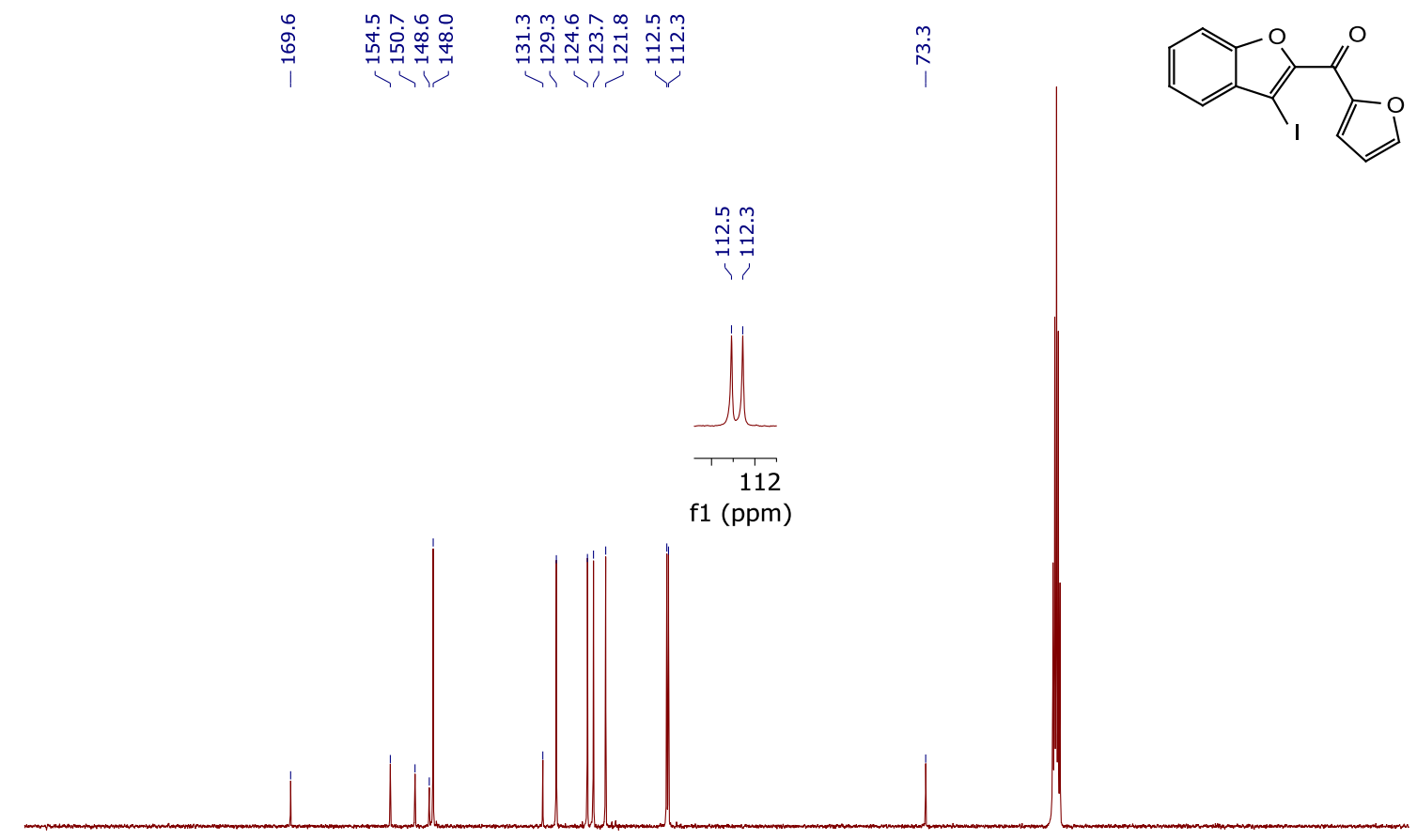

\begin{tabular}{|lllllllllllllllllllllll}
\hline 10 & 200 & 190 & 180 & 170 & 160 & 150 & 140 & 130 & 120 & 110 & 100 & 90 & 80 & 70 & 60 & 50 & 40 & 30 & 20 & 10 & 1
\end{tabular} f1 (ppm)

2l DEPT NMR spectra $\left(\mathrm{CD}_{2} \mathrm{Cl}_{2}\right)$

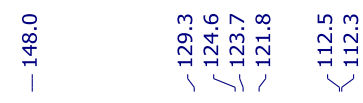
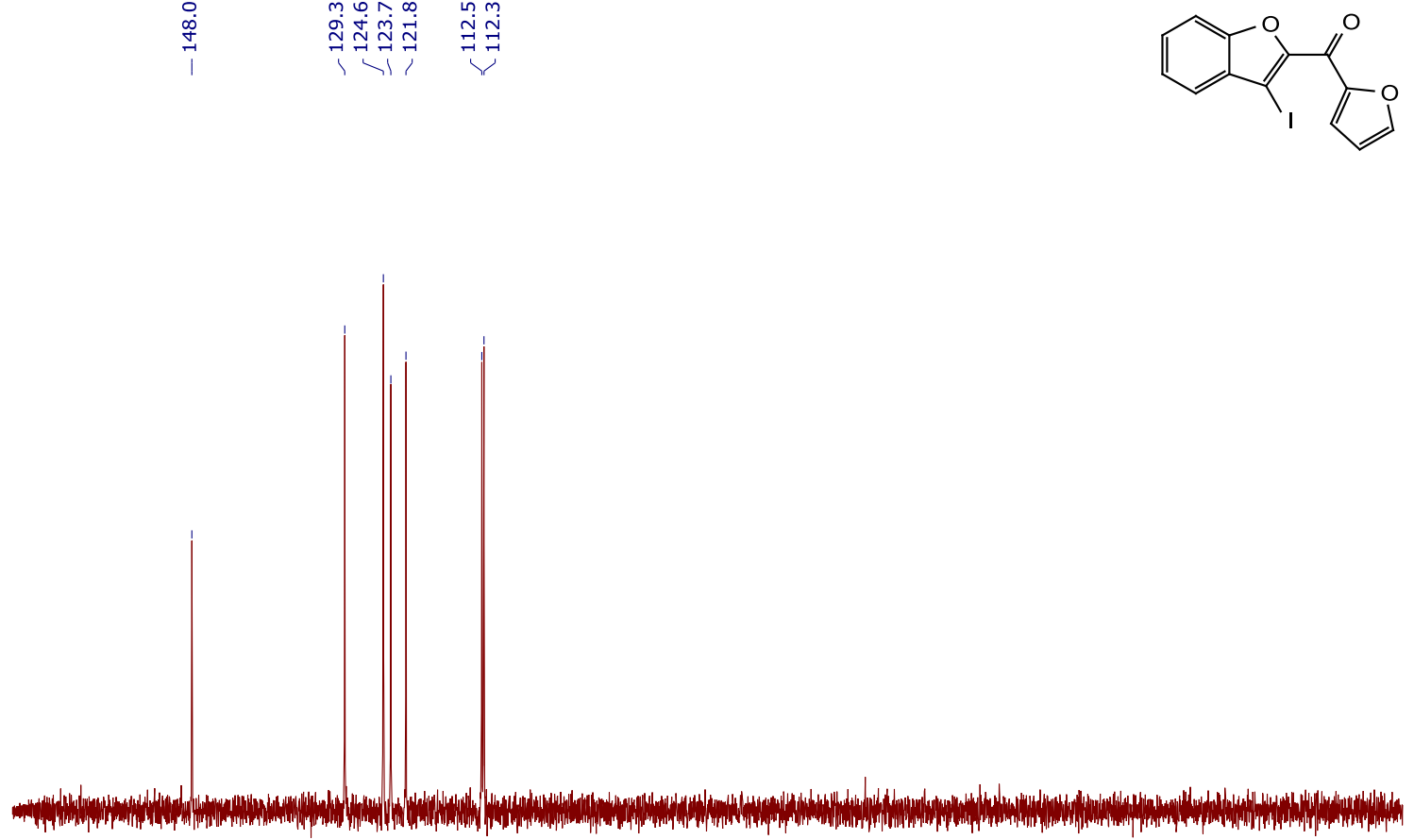

$\begin{array}{lllllllll}160 & 150 & 140 & 130 & 120 & 110 & 100 & 90 \begin{array}{r}80 \\ \mathrm{f} 1(\mathrm{ppm})\end{array}\end{array}$ 
$2 m \quad{ }^{1} \mathrm{H}$ NMR spectra $\left(\mathrm{CD}_{2} \mathrm{Cl}_{2}\right)$

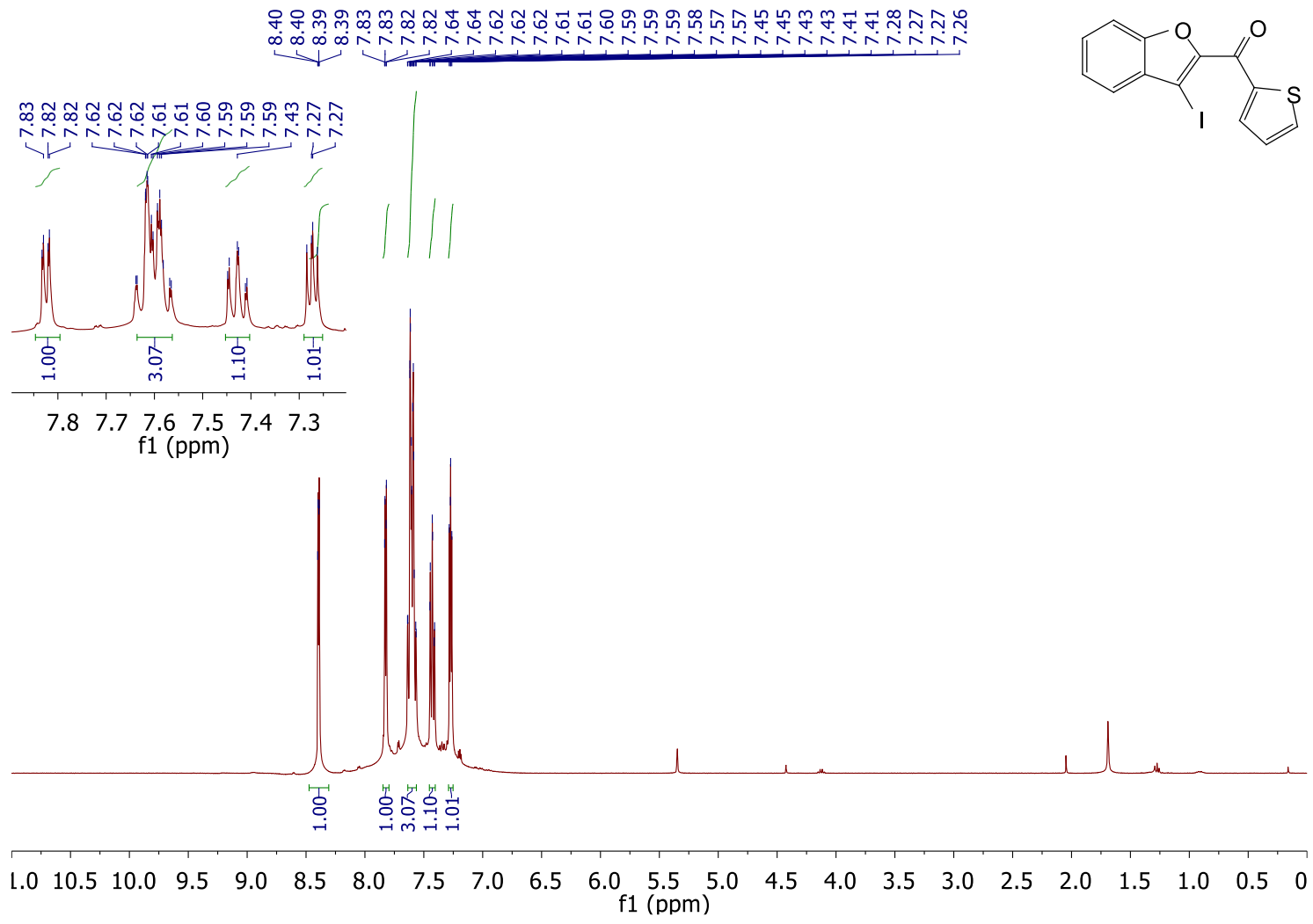

$2 m \quad{ }^{13} \mathrm{C}$ NMR spectra $\left(\mathrm{CD}_{2} \mathrm{Cl}_{2}\right)$

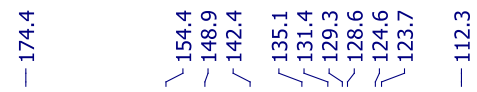

$\stackrel{\hat{n}}{\hat{i}}$
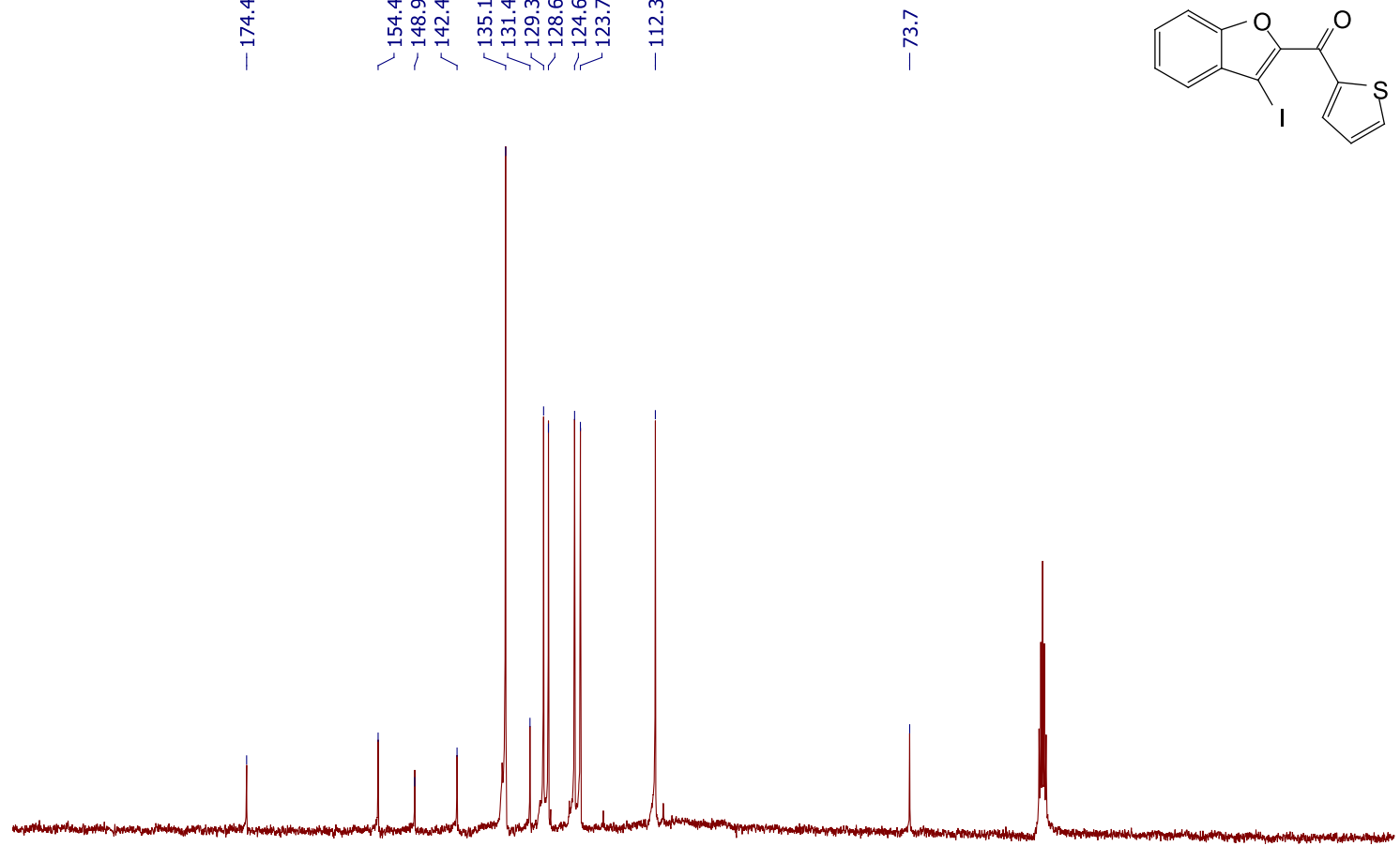

$\begin{array}{llllllllllllllllllllll}10 & 200 & 190 & 180 & 170 & 160 & 150 & 140 & 130 & 120 & 110 & 100 & 90 & 80 & 70 & 60 & 50 & 40 & 30 & 20 & 10 & 1\end{array}$ 
2n $\quad{ }^{1} \mathrm{H}$ NMR spectra $\left(\mathrm{CD}_{2} \mathrm{Cl}_{2}\right)$

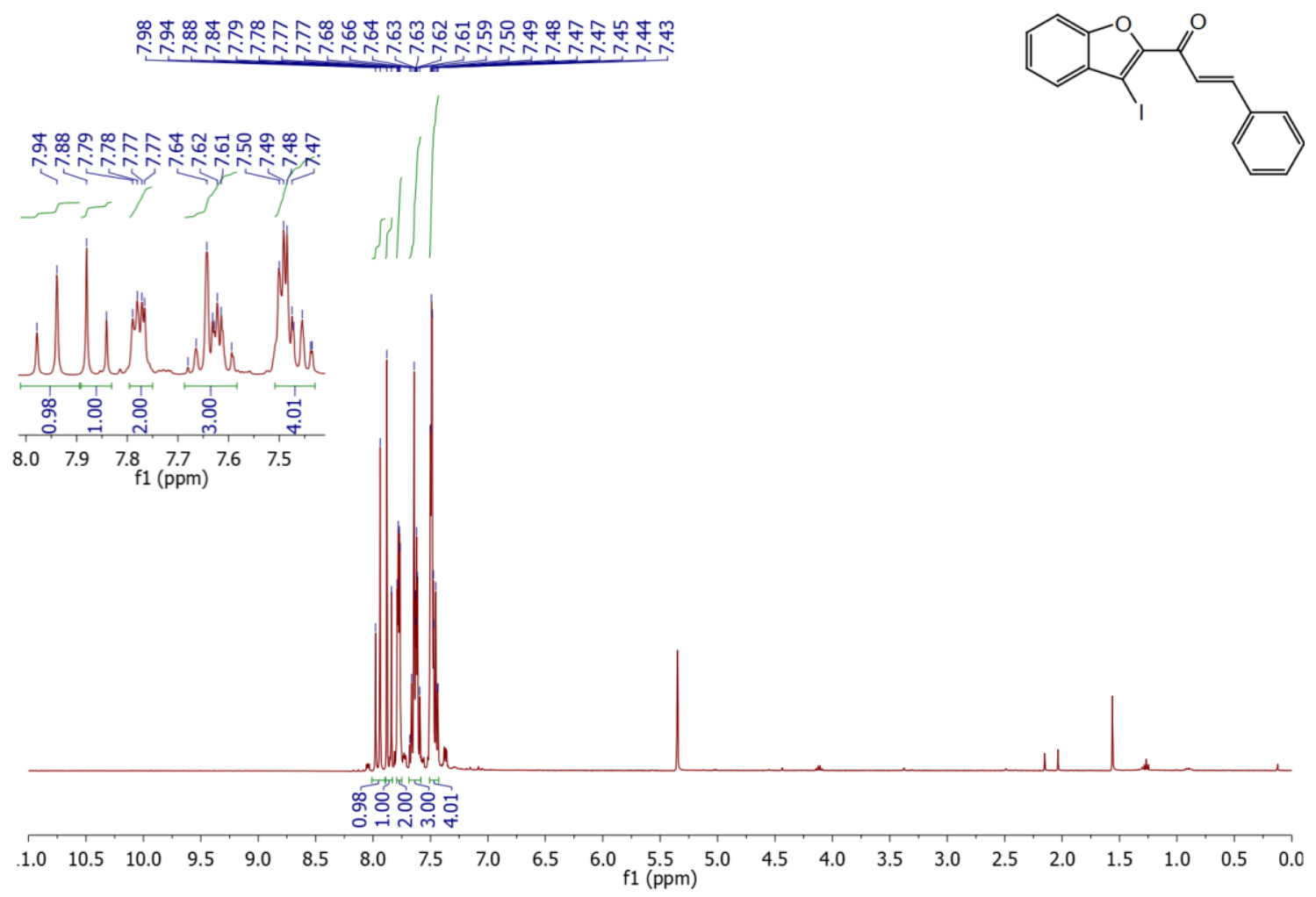

2n ${ }^{13} \mathrm{C}$ NMR spectra $\left(\mathrm{CD}_{2} \mathrm{Cl}_{2}\right)$

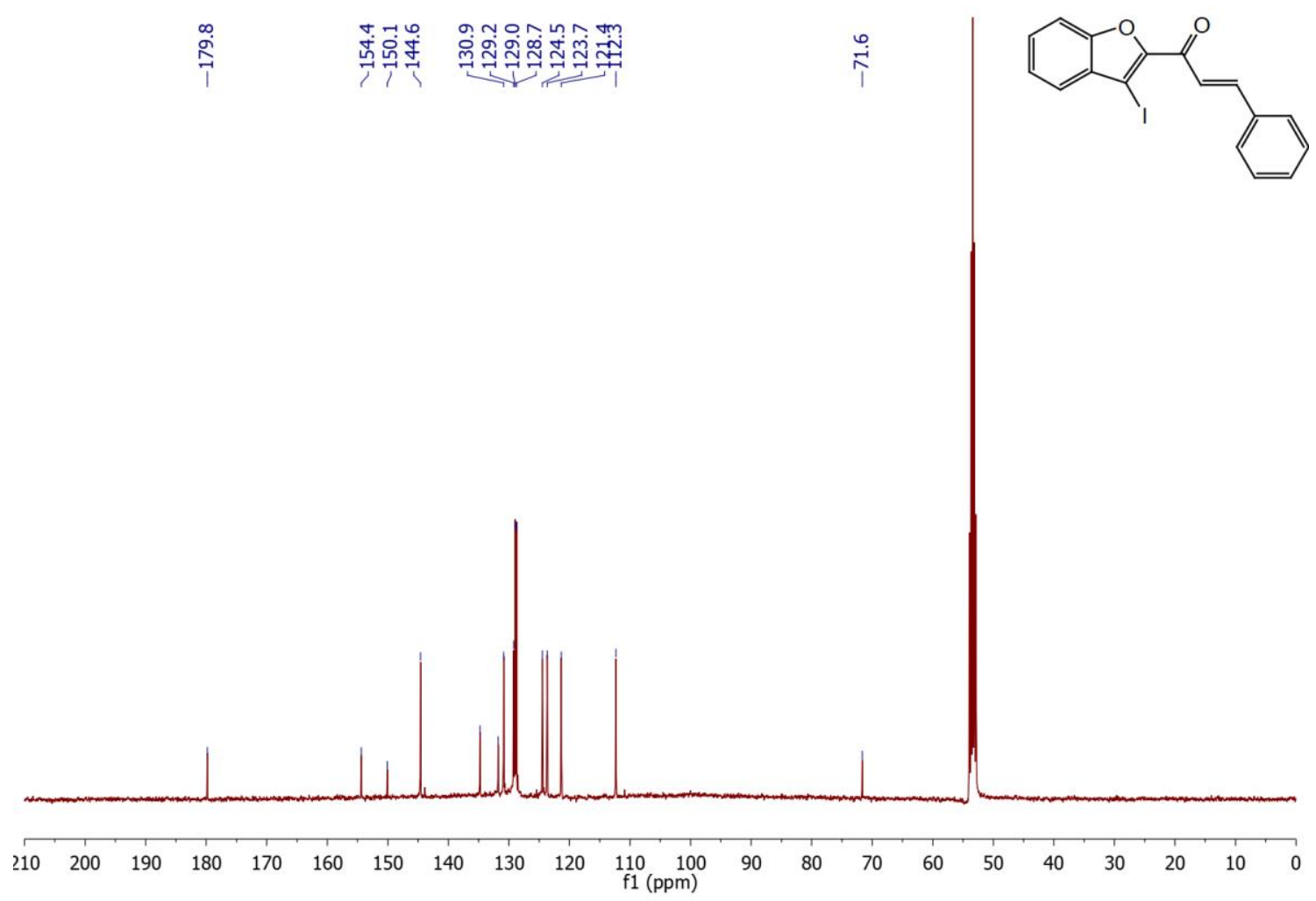




\section{告}
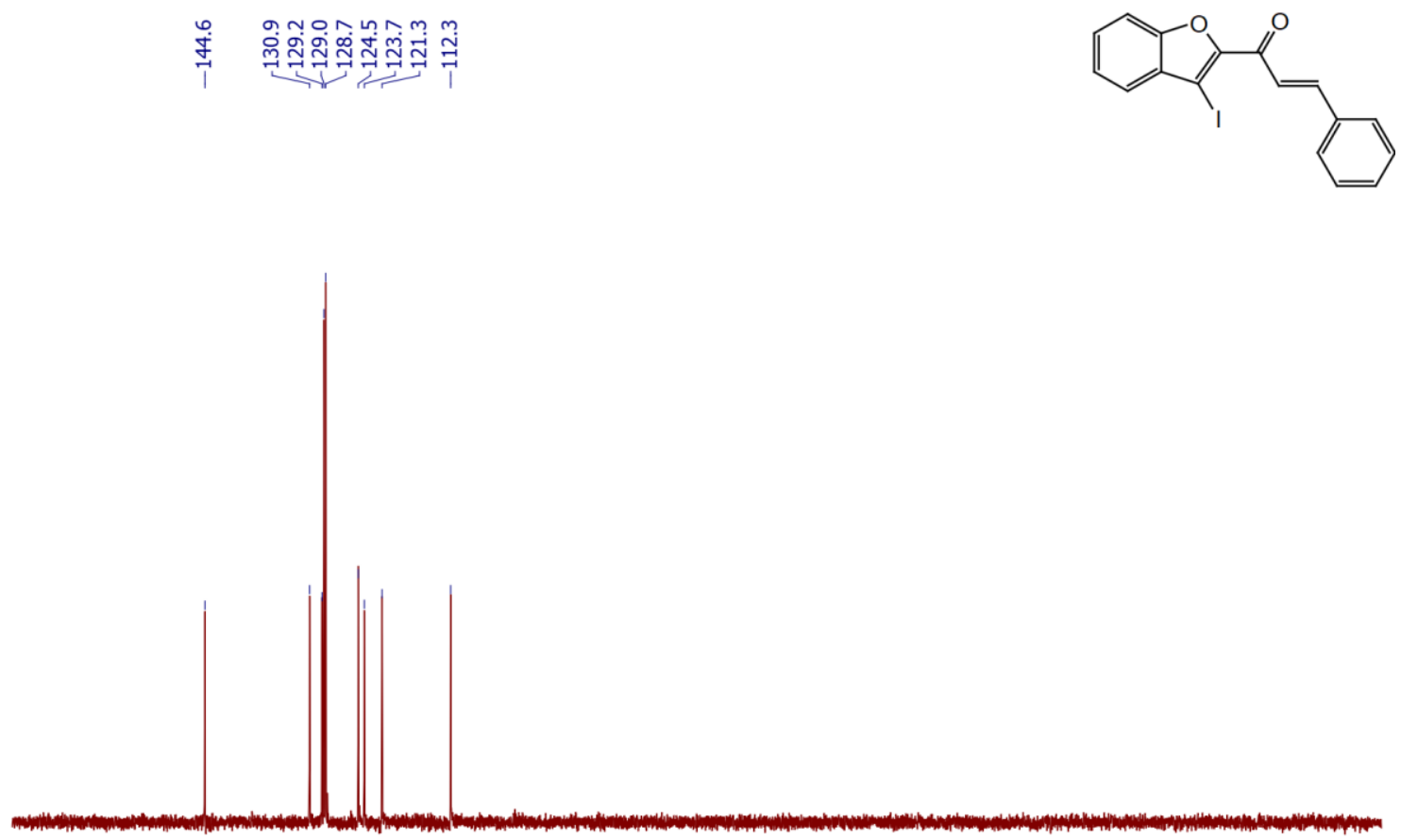

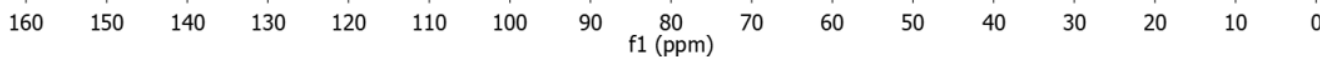

$20 \quad{ }^{1} \mathrm{H}$ NMR spectra $\left(\mathrm{CD}_{2} \mathrm{Cl}_{2}\right)$

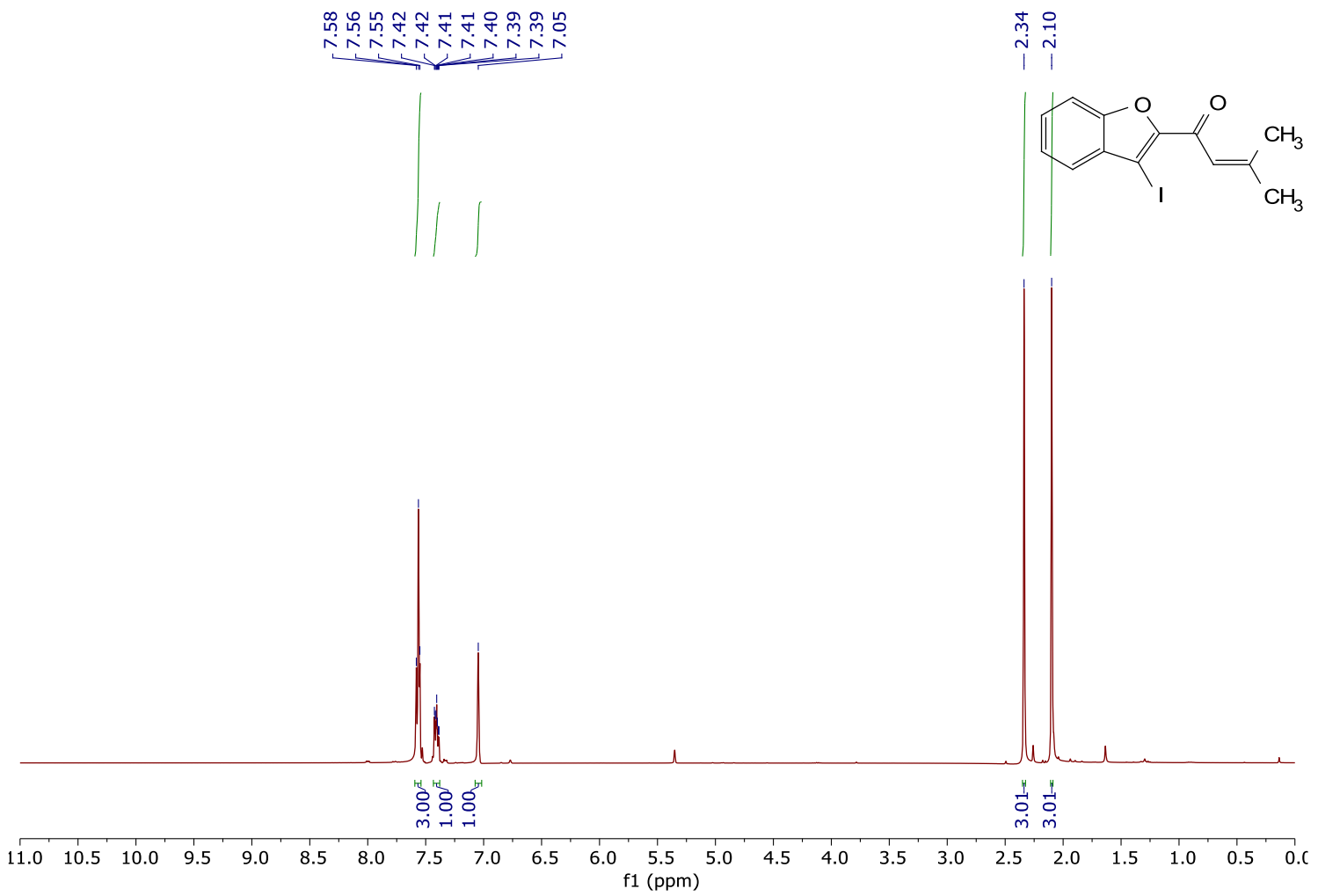




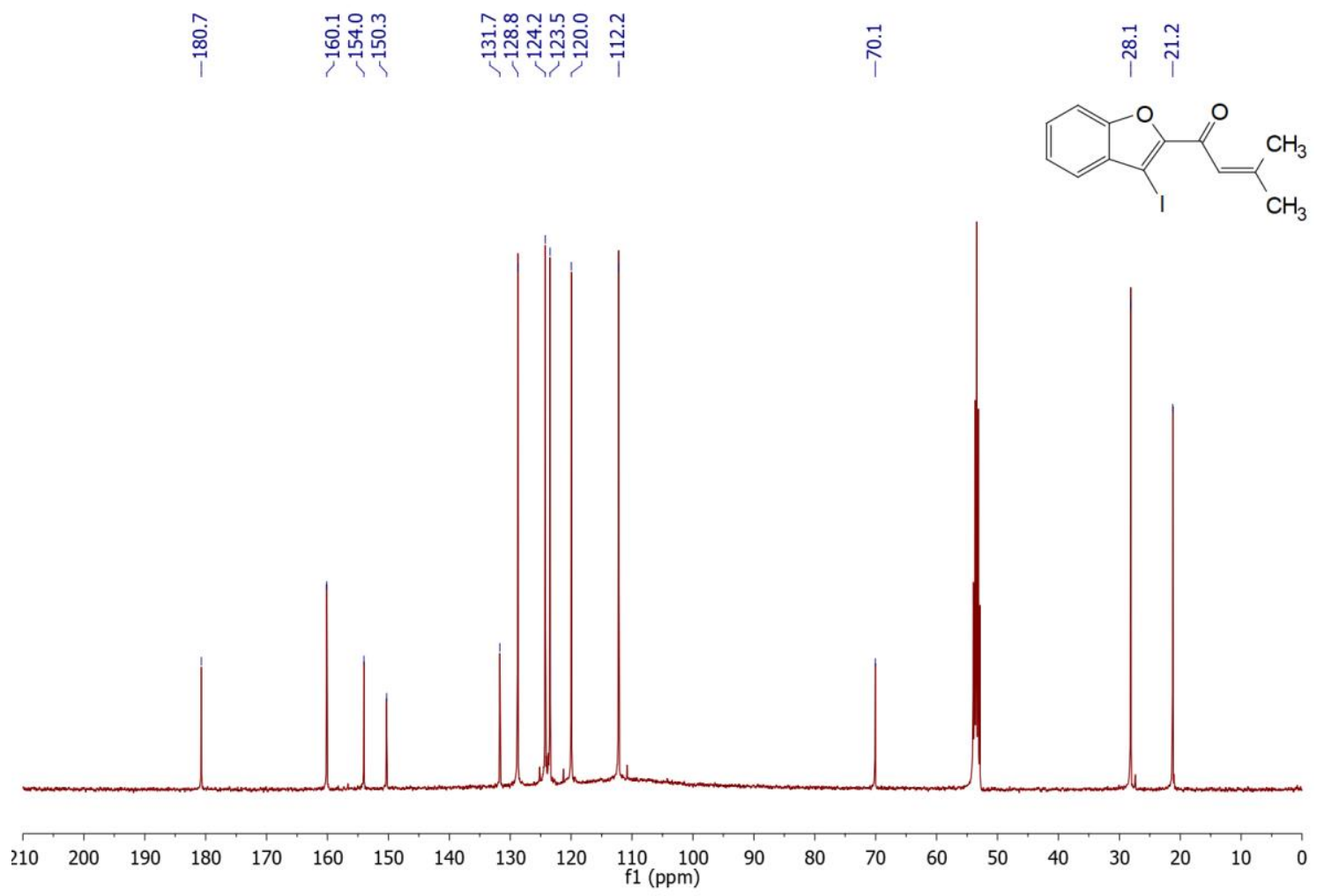

20 DEPT NMR spectra $\left(\mathrm{CD}_{2} \mathrm{Cl}_{2}\right)$

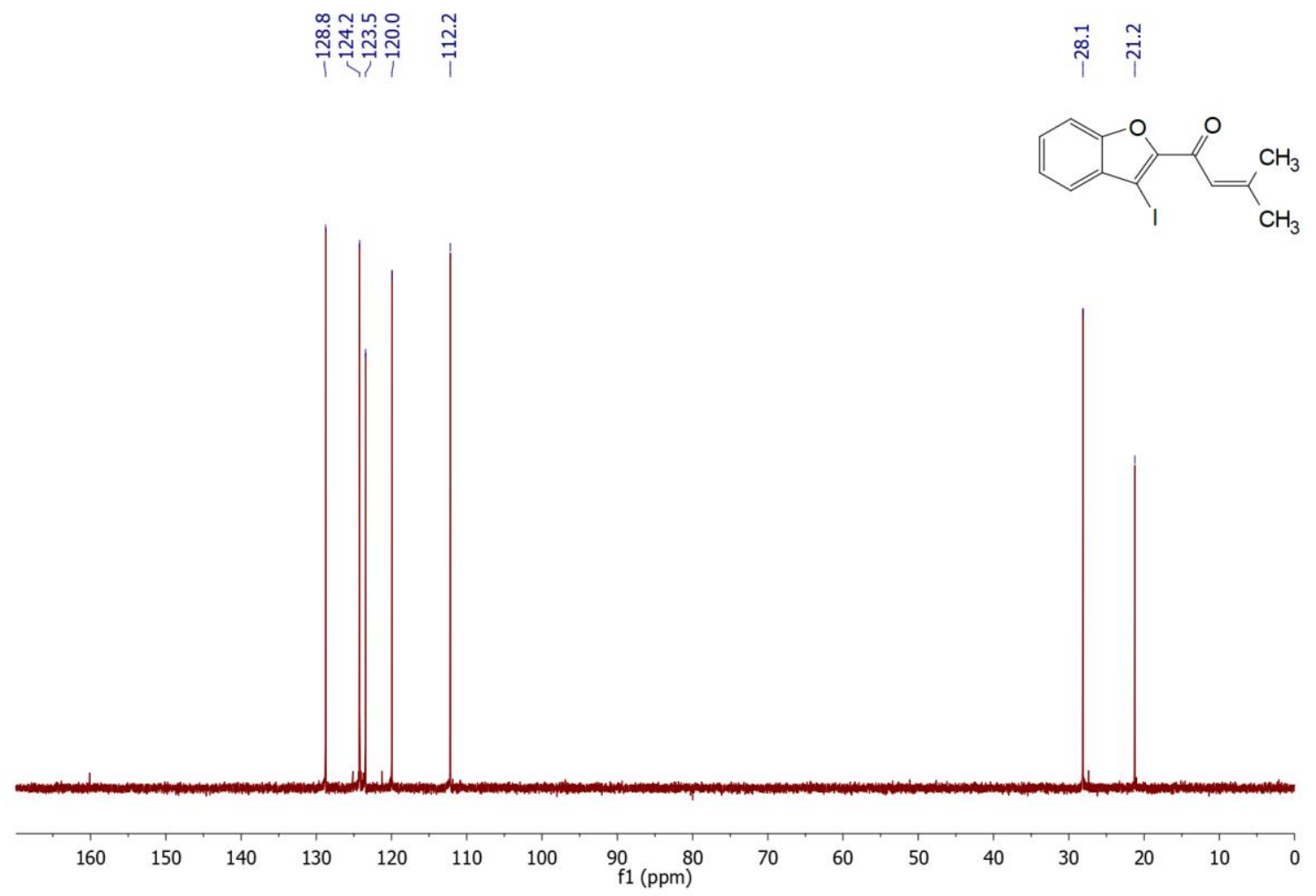




\section{2p ${ }^{1} \mathrm{H}$ NMR spectra $\left(\mathrm{CD}_{2} \mathrm{Cl}_{2}\right)$}

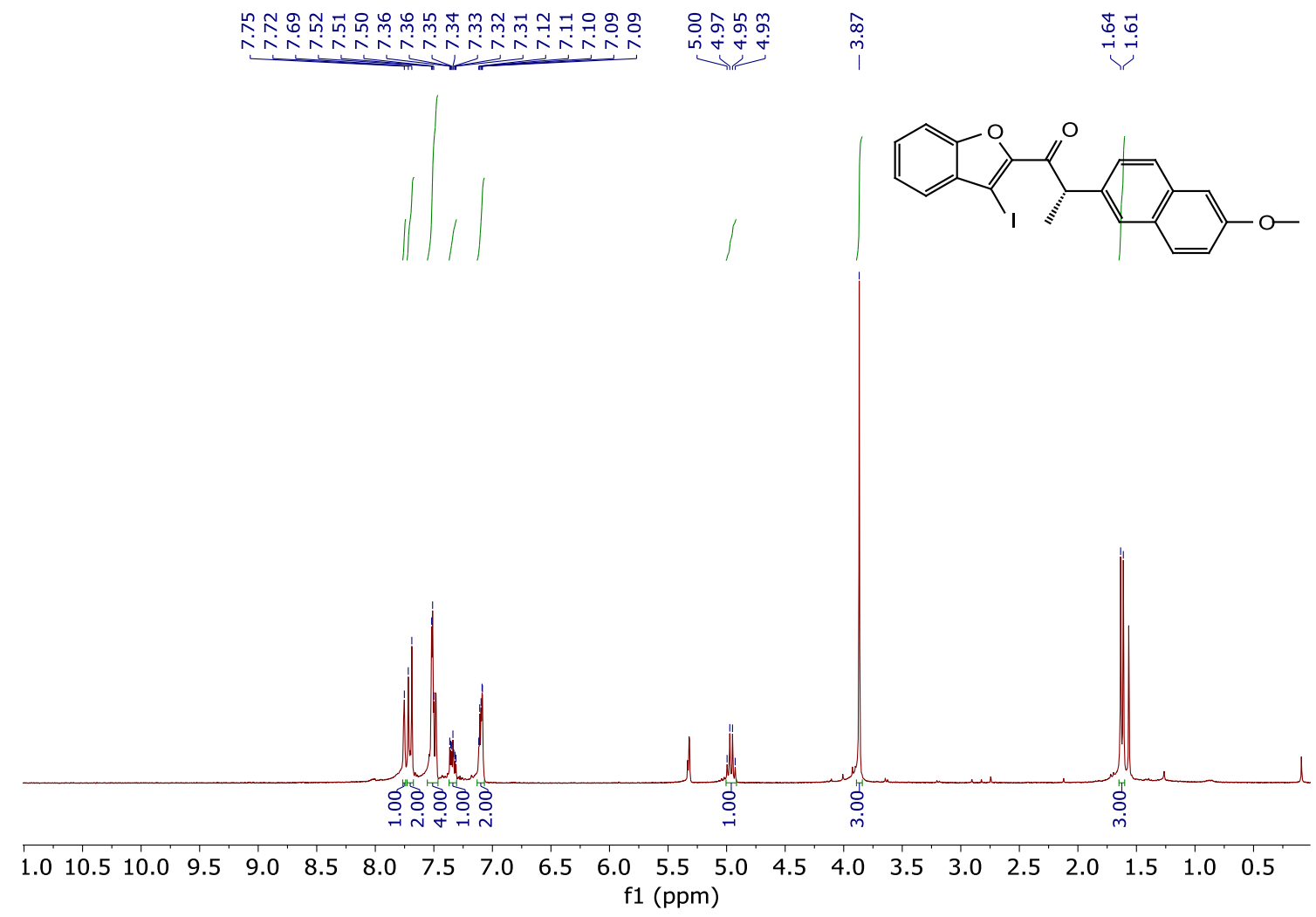

2p $\quad{ }^{13} \mathrm{C}$ NMR spectra $\left(\mathrm{CD}_{2} \mathrm{Cl}_{2}\right)$
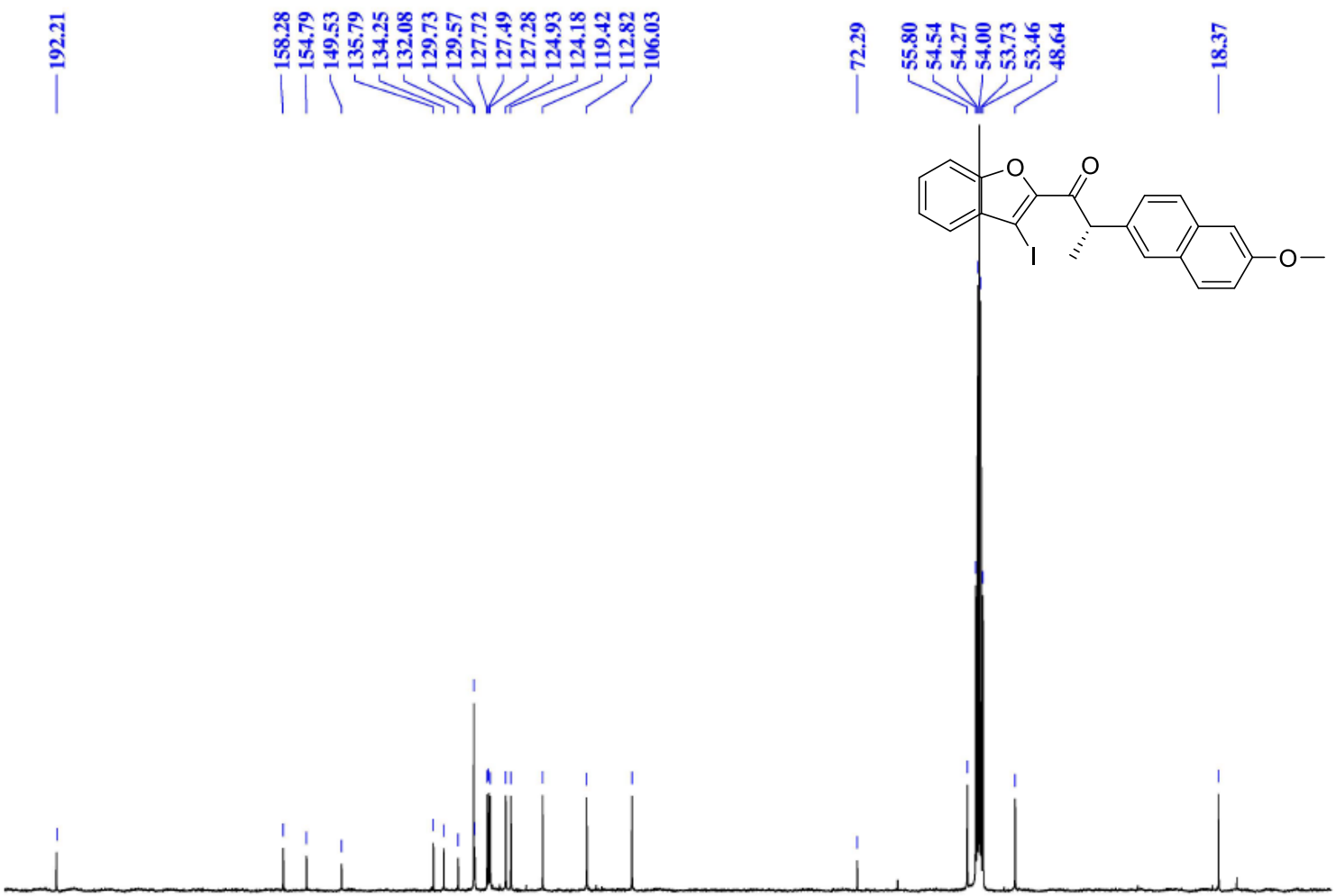

$\begin{array}{lllllllll}190 & 180 & 170 & 160 & 150 & 140 & 130 & 120 & 110\end{array}$

100 
2p DEPT NMR spectra $\left(\mathrm{CD}_{2} \mathrm{Cl}_{2}\right)$

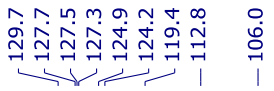
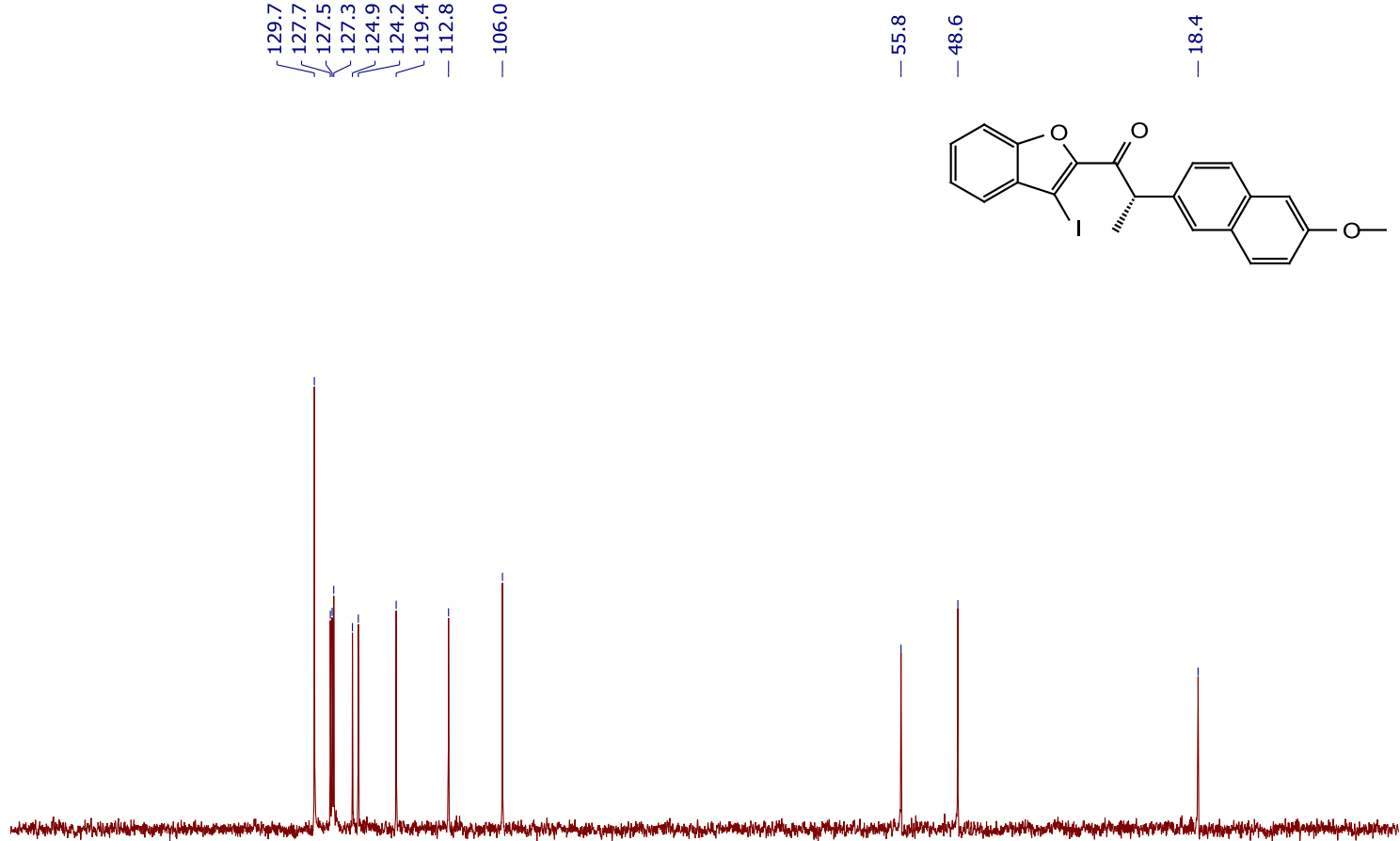

160

$\begin{array}{llllll}150 & 140 & 130 & 120 & 110 & 100\end{array}$

$\begin{array}{lllll}90 & 80 & 70 & 60 & 50\end{array}$ f1 (ppm) 


\section{6. $\quad$ X-Ray Crystal Structures}

CCDC 1917876 (2c) and CCDC 1917877 (2k) contains the supplementary crystallographic data for this paper. These data can be obtained free of charge from the Cambridge Crystallographic Data Centre via www.ccdc.cam.ac.uk/structures

\subsection{X-Ray Crystal Structure Determination for $2 \mathrm{c}$}

\section{1-(3-iodobenzofuran-2-yl)-3-methylbutan-1-one (2c)}<smiles>CC(C)CC(=O)c1oc2ccccc2c1I</smiles>

Cristal structure data for $\mathrm{C}_{13} \mathrm{H}_{13} \mathrm{IO}_{2}(2 \mathrm{c})$

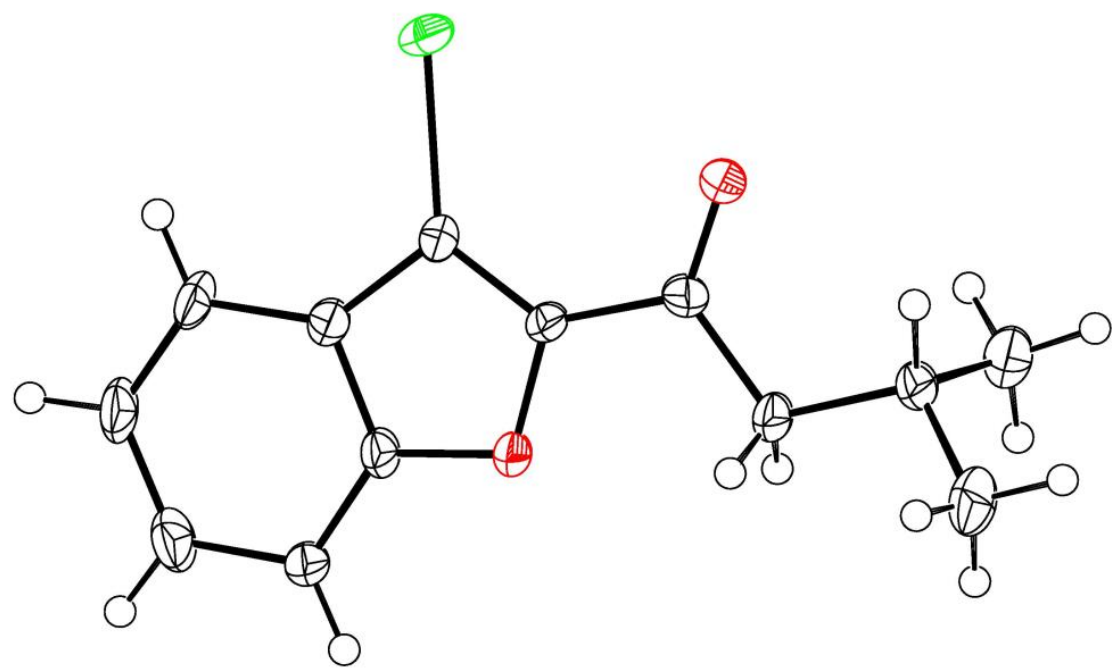

$50 \%$ probability level

$M_{r}=328.13 ; T=152(4) \mathrm{K} ; \lambda=1.54184 \AA$ А; Crystal system: Monoclinic; Space group: C2/c.

Unit cell dimensions: $a=7.0922(3), b=23.1472(11), c=15.0996(6) \AA ⿻ 冂 𠃍=97.280(4)^{\circ}$. Volume $=2458.84(18) \AA^{3} ; Z=8$, Calculated density $=1.773 \mathrm{Mgm}^{-3}$

Absorption coefficient: $20.330 \mathrm{~mm}^{-1} ; \mathbf{F}(\mathbf{0 0 0})=1280$; Crystal size: $0.31 \times 0.11 \times 0.07 \mathrm{~mm}$.

$\theta$ range data collection $=6.577-69.707^{\circ} ;$ Index ranges: $-8 \leq h \leq 8,-27 \leq k \leq 27,-17 \leq k 18 ;$ Reflections collected/unique $=10059 / 2095$ $\left[R_{\text {int }}=0.0830\right.$; Completeness to $2 \theta=67.4579(89.5 \%)$; Absortion correction: Semiempirical from equivalents; Max. and min. transmission $=1.0000$ and 0.30971 ; Refinement method: full matrix least-squares on $F^{2}$; Data $/$ restraints $/$ parameters $=$ 2095/0/147; Goodness-of-fit on $F^{2}=1.086$; Final $\boldsymbol{R}$ indices [ $\left.\$ 2 \sigma(I)\right]: R_{1}=0.0386, w R_{2}=0.0976 ; \boldsymbol{R}$ indices (all data): $R_{1}=$ $0.0438, w R_{2}=0.0996$; Largest difference peak and hole $=1.178$ and $-0.995 \mathrm{e}^{-3}$.

Deposit number: CCDC 1917876 


\section{2. $\underline{X}$-Ray Crystal Structure Determination for $2 \mathrm{k}$}

(3-iodo-5,7-dimethylbenzofuran-2-yl)(phenyl)methanone (2k)<smiles>Cc1cc(C)c2oc(C(=O)c3ccccc3)c(I)c2c1</smiles>

Cristal structure data for $\mathrm{C}_{17} \mathrm{H}_{13} \mathrm{IO}_{2}$ (2k)

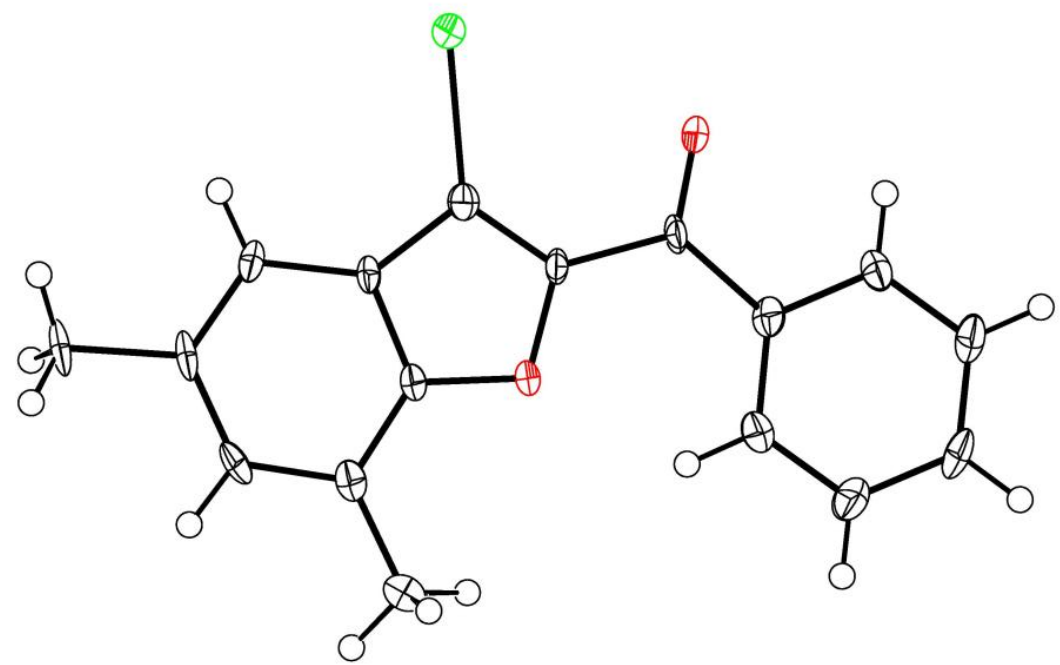

$50 \%$ probability level

$\boldsymbol{M}_{r}=376.17 ; \boldsymbol{T}=293$ (2) $\mathrm{K} ; \lambda=1.54184 \AA$; Crystal system: Triclinic; Space group: $P-1$.

Unit cell dimensions: $a=7.4393$ (3), $b=9.7836$ (4), $c=10.2982$ (4) $\AA, \alpha=90.136(3)^{\circ}, \beta=108.044(4)^{\circ}, \gamma=95.467$ (3), . Volume $=$ $709.03(5) \AA^{3} ; Z=2$, Calculated density $=1.762 \mathrm{Mgm}^{-3}$

Absorption coefficient: $17.727 \mathrm{~mm}^{-1} ; \mathbf{F}(\mathbf{0 0 0})=368$; Crystal size: $0.679 \times 0.323 \times 0.313 \mathrm{~mm}$

$\theta$ range data collection $=4.518-69.526^{\circ} ;$ Index ranges: $-8 \leq h \leq 8,-11 \leq k \leq 11,-12 \leq k \leq 12 ;$ Reflections collected/unique $=5347 / 2612$ $\left[R_{\text {int }}=0.0880\right]$; Completeness to $2 \theta=70.00(97.4 \%)$; Absorption correction: analytical; Max. and min. transmission $=1.0000$ and 0.3310; Refinement method: full matrix least-squares on $F$; Data /restraints / parameters =2612/0/183; Goodness-of-fit on $F^{2}=1.109 ;$ Final $\boldsymbol{R}$ indices $[>2 \sigma(I)]: R_{1}=0.0794, w R_{2}=0.2150 ; \boldsymbol{R}$ indices (all data): $R_{1}=0.0798, w R_{2}=0.2164 ;$ Largest difference peak and hole $=3.399$ and $-2.588 \mathrm{e}^{-3}$.

Deposit number: CCDC 1917877 


\section{7. $\quad$ HPLC analysis}

\subsection{HPLC data of starting materials}

Column: CHIRALPAK ${ }^{\circledR} \mathrm{AD}-\mathrm{H}, 4.6 \mathrm{~mm} \varnothing \times 250 \mathrm{mml}$

Precolumn: CHIRALPAK ${ }^{\circledR} \mathrm{AD}-\mathrm{H}, 4.0 \mathrm{~mm} \varnothing \times 10 \mathrm{mml}$ (3 pieces)

Solvent: Isopropanol:hexane (10:90)

Flow: $0.5 \mathrm{ml} / \mathrm{min}$

Injection: $10 \mu \mathrm{l}$

Temperature-column: $30 \stackrel{\circ}{ } \mathrm{C}$

Temperature-sample: $10 \stackrel{\circ}{\mathrm{C}}$

\section{Racemic 2-(iodoethynyl)phenyl 2-(6-methoxynaphthalen-2-yl)propanoate (rac-1p)}<smiles>COc1ccc2cc(C(C)C(=O)Oc3ccccc3C#CI)ccc2c1</smiles>

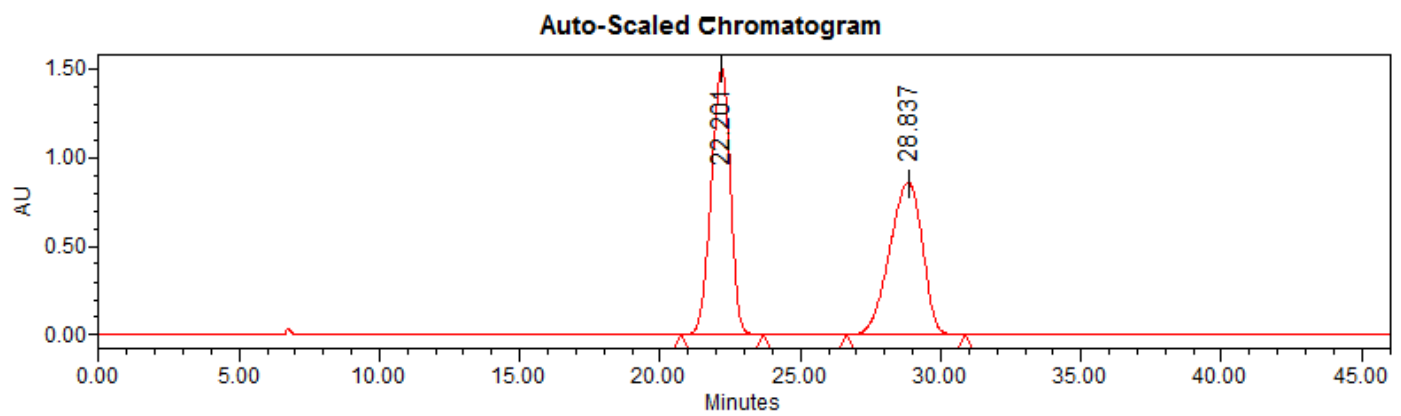

\section{Unknown Peak Results}

\begin{tabular}{|c|l|c|c|r|r|}
\hline$\approx$ & Peak Type & RT & Area & $\%$ Area & Height \\
\hline 1 & Unknown & 22.201 & 71032335 & 50.52 & 1496492 \\
\hline 2 & Unknown & 28.837 & 69556203 & 49.48 & 857404 \\
\hline
\end{tabular}

Enantioenriched 2-(iodoethynyl)phenyl (S)-2-(6-methoxynaphthalen-2-yl)propanoate (1p)<smiles>COc1ccc2cc([C@@H](C)C(=O)Oc3ccccc3C#CI)ccc2c1</smiles>

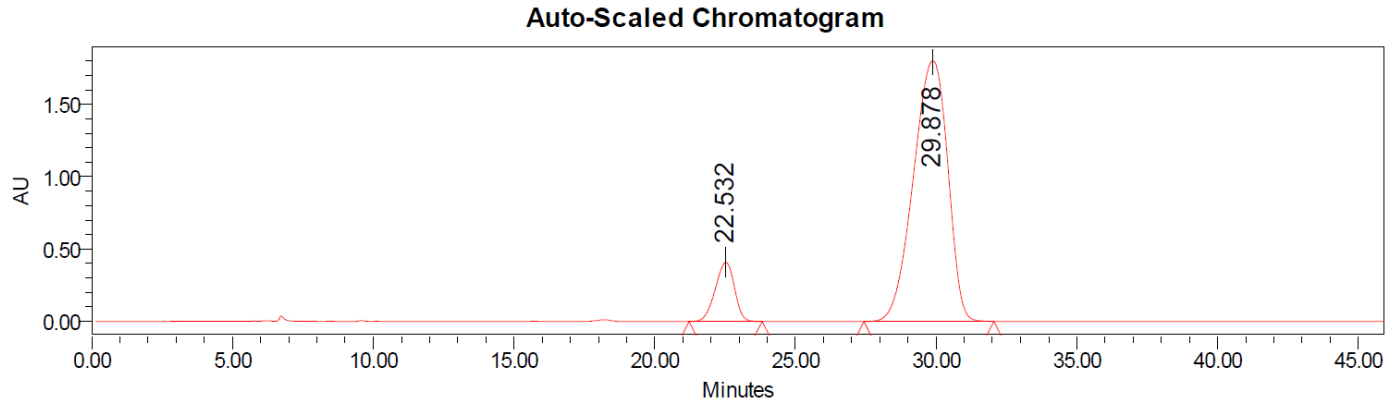

Unknown Peak Results

\begin{tabular}{|l|l|c|c|r|c|}
\hline & Peak Type & RT & Area & $\%$ Area & Height \\
\hline 1 & Unknown & 22.532 & 19423822 & 11.26 & 409313 \\
\hline 2 & Unknown & 29.878 & 153056440 & 88.74 & 1804170 \\
\hline
\end{tabular}




\subsection{HPLC data of final products}

Column: CHIRALPAK ${ }^{\circledR}$ AD-H, $4.6 \mathrm{~mm} \varnothing \times 250 \mathrm{mml}$

Precolumn: CHIRALPAK ${ }^{\circledR}$ AD-H, $4.0 \mathrm{~mm} \varnothing \times 10 \mathrm{mml}$ (3 pieces)

Solvent: Isopropanol:hexane (10:90)

Flow: $0.5 \mathrm{ml} / \mathrm{min}$

Injection: $10 \mu \mathrm{l}$

Temperature column: $30 \stackrel{\circ}{\circ}$

Temperature sample: $10^{\circ} \mathrm{C}$

\section{1-(3-iodobenzofuran-2-yl)-2-(6-methoxynaphthalen-2-yl)propan-1-one (rac-2p)}<smiles>CCCCCOC(C)(C)CCCCC</smiles>

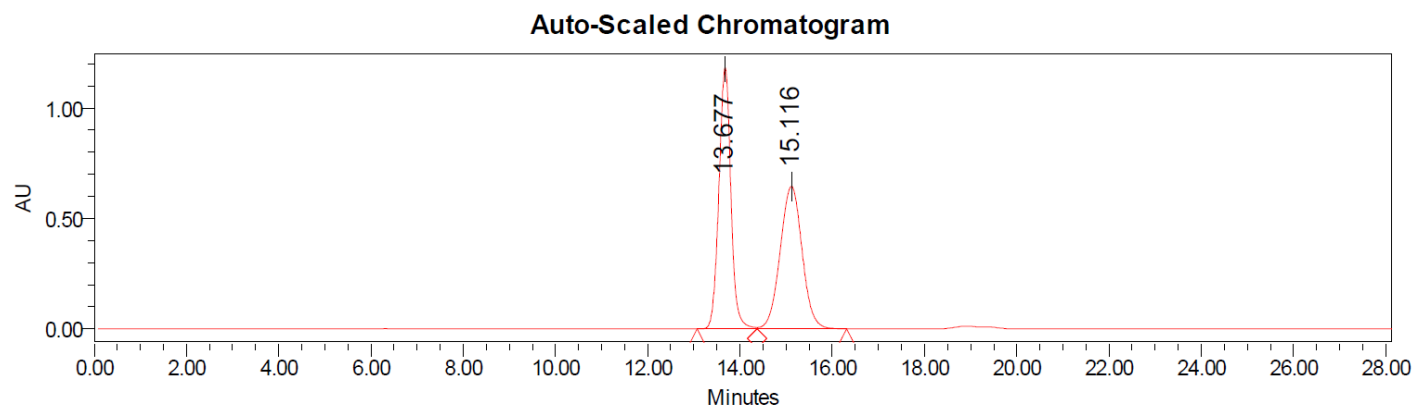

Unknown Peak Results

\begin{tabular}{|l|l|c|c|r|r|}
\hline & Peak Type & RT & Area & \% Area & Height \\
\hline 1 & Unknown & 13.677 & 21317354 & 49.94 & 1183961 \\
\hline 2 & Unknown & 15.116 & 21368790 & 50.06 & 646205 \\
\hline
\end{tabular}

Enantioenriched (S)-1-(3-iodobenzofuran-2-yl)-2-(6-methoxynaphthalen-2-yl)propan-1-one (2p)<smiles>COc1ccc2cc([C@@H](C)C(=O)c3oc4ccccc4c3I)ccc2c1</smiles>

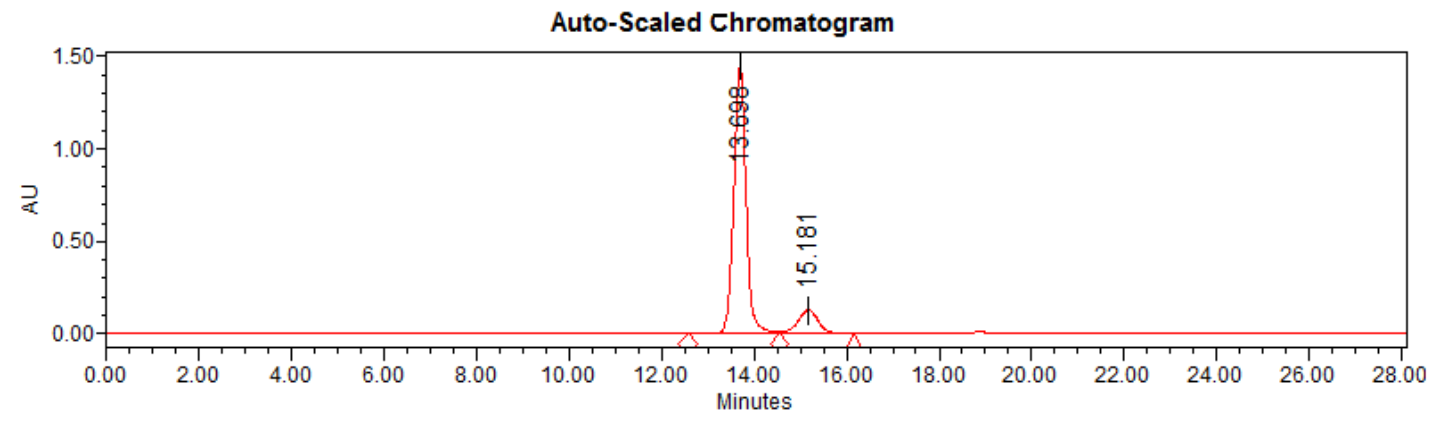

Unknown Peak Results

\begin{tabular}{|c|l|c|r|r|c|}
\hline 2 & Peak Type & RT & \multicolumn{1}{c|}{ Area } & \% Area & Height \\
\hline 1 & Unknown & 13.698 & 26604015 & 87.17 & 1446307 \\
\hline 2 & Unknown & 15.181 & 3917153 & 12.83 & 127045 \\
\hline
\end{tabular}




\section{Crossover reaction}<smiles>O=C(Oc1ccc(Cl)cc1C#CI)c1ccccc1</smiles>

$1 \mathrm{~h}$<smiles>O=C(Oc1ccccc1C#CI)c1cccs1</smiles>

$1 \mathrm{~m}$
$\left[\operatorname{IPrAu}\left(\mathrm{CH}_{3} \mathrm{CN}\right)\right]\left[\mathrm{SbF}_{6}\right]$ $2.5 \mathrm{~mol} \%$

$$
\begin{gathered}
\mathrm{ClCH}_{2} \mathrm{CH}_{2} \mathrm{Cl}(0.1 \mathrm{M}) \\
80^{\circ} \mathrm{C}
\end{gathered}
$$

$$
\text { (Using } \mathrm{CH}_{2} \mathrm{Br}_{2}
$$

as internal standard)<smiles>O=C(c1ccccc1)c1oc2ccc(Cl)cc2c1I</smiles>

2h, $96 \%$<smiles>O=C(c1cccs1)c1oc2ccccc2c1I</smiles>

$2 \mathrm{~m}, 78 \%$

The crossover experiment was performed following the general method for the catalytic cycloisomerizations of the compounds (2). The two starting material (1h and $1 \mathrm{~m})(0.4 \mathrm{mmol}, 0.2 \mathrm{mmol}$ of each), in dry 1,2-dichloethane (4 ml) with a concentration of $0.1 \mathrm{M}$ in relation to both substrates, and adding $2.5 \mathrm{~mol} \%$ of the catalyst $(8.7 \mathrm{mg})$ with respect to the two starting material was added in a carusel tube. The reaction was carried out under argon atmosphere, at $80^{\circ} \mathrm{C}$, for 2 hours.

The reaction was monitored by TLC, until consumption of the starting materials was noticed. Then, the solvent was evaporated, and $\mathrm{CH}_{2} \mathrm{Br}_{2}$ was added to the sample, as internal standard to determine the yields.

In the picture below, representative ${ }^{1} \mathrm{H}$ NMR spectra are shown: the compound $\mathbf{2 h}$ (green), the compound $\mathbf{2 m}$ (blue) and the crossing experiment (red). The characteristic signals of products $\mathbf{2 h}$ and $\mathbf{2 m}$ are perfectly distinguished in the spectra of the crossover reaction. No evidence of the presence of the starting material is observed. The lack of formation of new peaks, led to the conclusion that no crossover reaction took place.

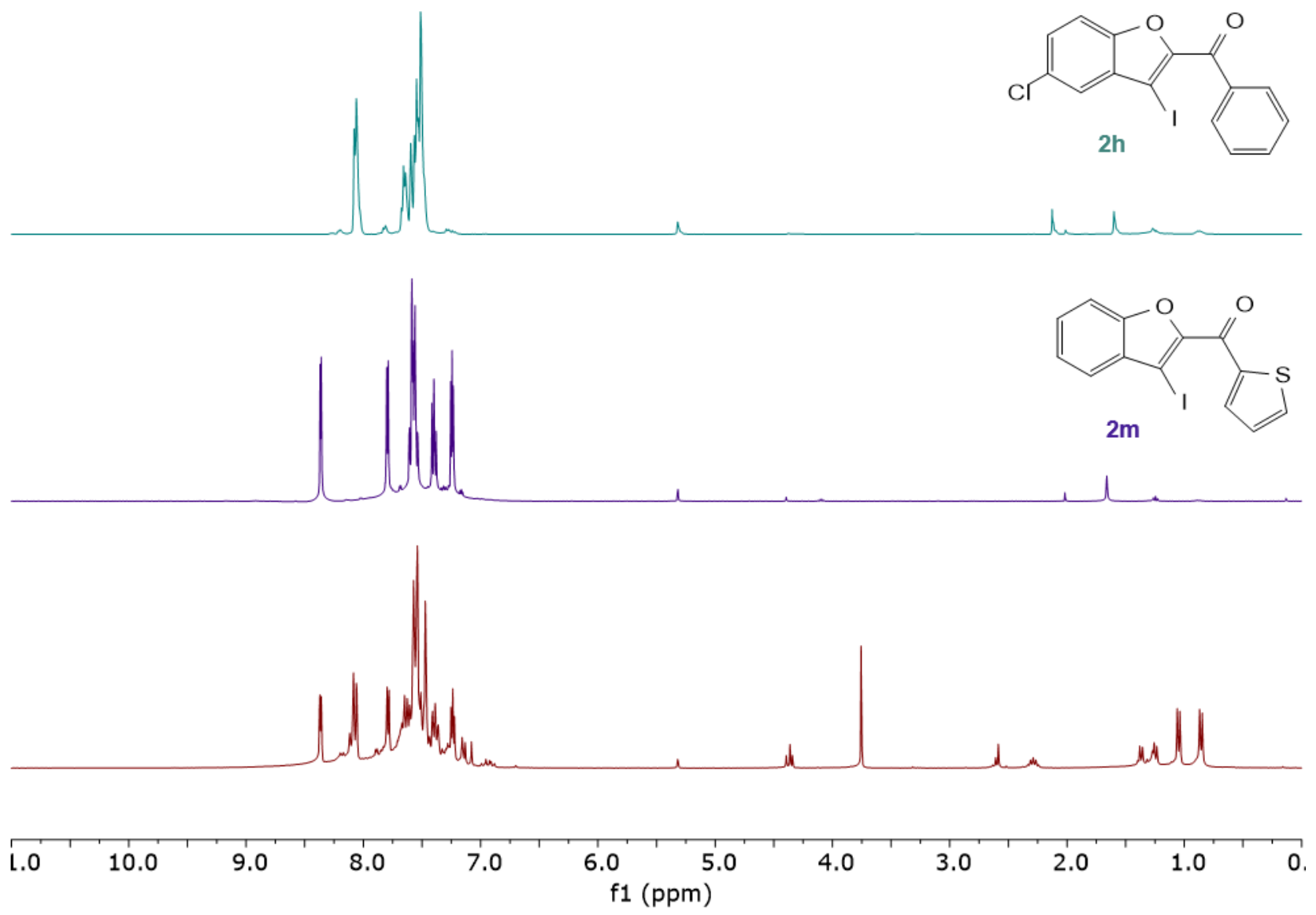




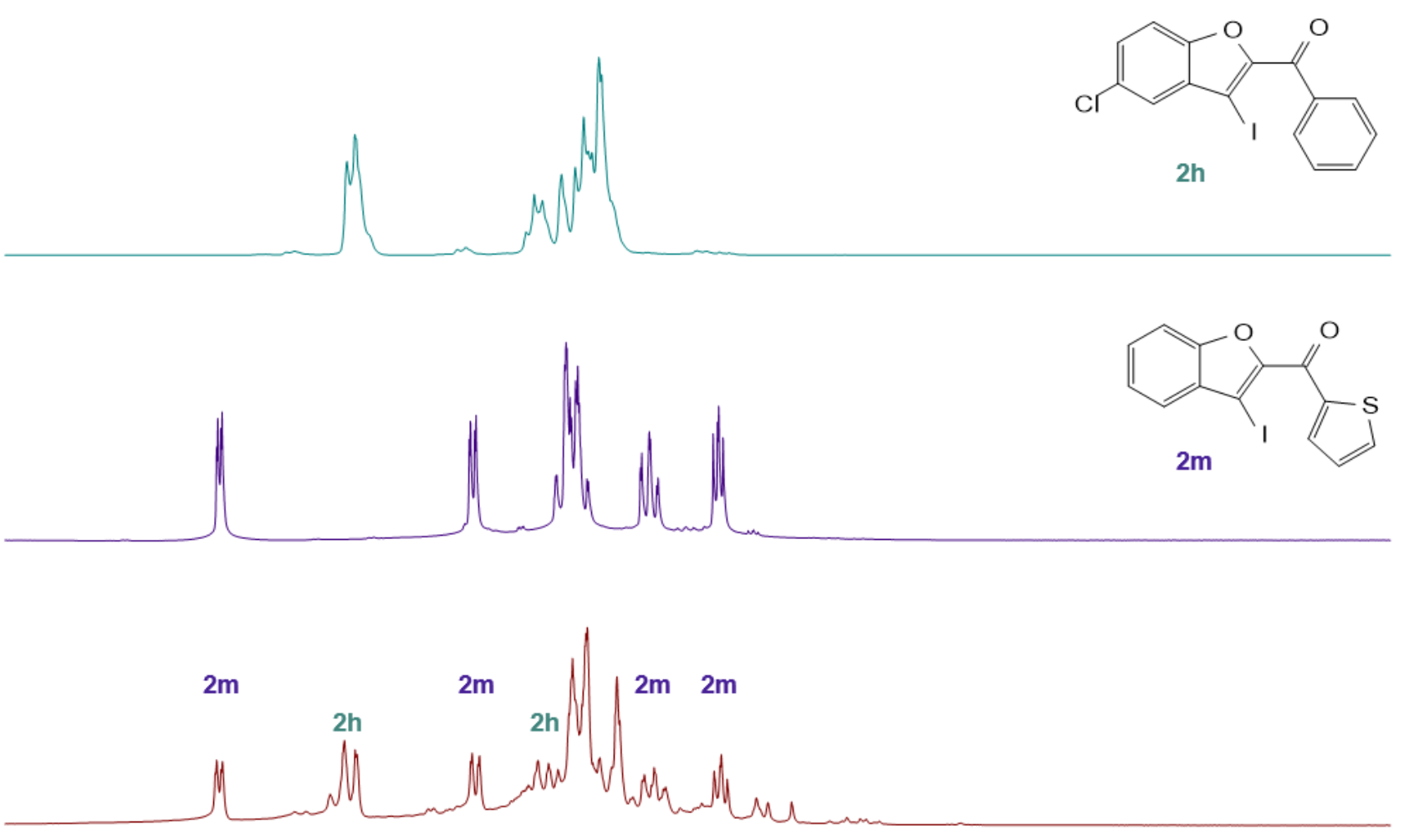

\begin{tabular}{|c|c|c|c|c|c|c|c|c|c|c|c|c|c|c|c|}
\hline 8.8 & 8.6 & 8.4 & 8.2 & 8.0 & 7.8 & 7.6 & $\begin{array}{r}7.4 \\
\text { f1 }\end{array}$ & $\begin{array}{r}7.2 \\
\mathrm{ppm})\end{array}$ & 7.0 & 6.8 & 6.6 & 6.4 & 6.2 & 6.0 & 5.8 \\
\hline
\end{tabular}




\section{Reference}

${ }^{1}$ Fürstner, A.; Davies, P. W. Heterocycles by $\mathrm{PtCl}_{2}$-Catalyzed Intramolecular Carboalkoxylation or Carboamination of Alkynes. J. Am. Chem. Soc. 2005, 127, 15024-15025. http://dx.doi.org/10.1021/ja055659p

${ }^{2}$ For the general method click here.

${ }^{3}$ Meraz, K.; Gnanasekaran, K. K.; Thing, R.; Bunce, R. A. Bismuth(III) triflate catalyzed tandem esterification-Fries-oxa-Michael route to 4chromanones. Tetrahedron Lett. 2016, 57, 5057-5061. https://doi.org/10.1016/j.tetlet.2016.10.005

${ }^{4}$ Pablo Morán-Poladura, PhD thesis "Activación electrófila de sistemas insaturados: aplicaciones en síntesis de estructura carbo- y heterociclas y exploración de nuevas transformaciones sintéticas", University of Oviedo, 2015. http://hdll.handle.net/10651/33974

${ }^{5}$ Álvarez-Calero, J. M.; Jorge, Z. D.; Massanet, G. M. TiCl $/ \mathrm{Et}_{3} \mathrm{~N}$-Mediated Condensation of Acetate and Formate Esters: Direct Access to $\beta$ Alkoxy- and $\beta$-Aryloxyacrylates. Org. Lett. 2016, 18, 6344-6347. https://doi.org/10.1021/acs.orglett.6b03233

${ }^{6}$ Simion, A. M.; Hashimoto, I.; Mitoma, Y.; Egashira, N.; Simion, C. O-Acylation of Substituted Phenols with Various Alkanoyl Chlorides Under Phase-Transfer Catalyst Conditions. Synthetic Communications, 2012, 42, 921-931. https://doi.org/10.1080/00397911.2011.584007

${ }^{7}$ Lehnherr, D.; Alzola, J. M.; Lobkovsky, E. B.; Dichtel, W. R. Regioselective Synthesis of Polyheterohalogenated Naphthalenes via the Benzannulation of Haloalkynes. Chem. Eur. J. 2015, 21, 18122-18127. http://dx.doi.org/10.1002/chem.201503418

${ }^{8} \mathrm{PhD}$ thesis Marta Pérez Álvarez, University of Oviedo, 1997. "Aplicación del ipy ${ }_{2} \mathrm{bf}_{4}$ en la elaboración de índoles y de otras sustancias de interés biológico por yodación de moléculas ópticamente puras". http://hdl.handle.net/10651/13667

${ }^{9}$ Abouelhassan, Y.; Garrison, A. T.; Burch, G. M.; Wong, W.; Norwood, V. M.; Huigens, R. W. Discovery of quinoline small molecules with potent dispersal activity against methicillin-resistant Staphylococcus aureus and Staphylococcus epidermidis biofilms using a scaffold hopping strategy. Bioorg. Med. Chem. Lett. 2014, 24, 5076-5080.

https://doi.org/10.1016/j.bmcl.2014.09.009

${ }_{10}$ White, J. D.; Shaw, S. A New Cobalt-Salen Catalyst for Asymmetric Cyclopropanation. Synthesis of the Serotonin-Norepinephrine Repuptake Inhibitor (+)-Synosutine. Org. Lett. 2014, 16, 3880-3883. https://doi.org/10.1021/0l501549x

${ }_{11}$ Jarava-Barrera, C.; Parra, A.; López, A.; Cruz-Acosta, F.; Collado-Sanz, D.; Cárdenas, D. J.; Tortosa, M. Copper-Catalyzed Borylative Aromatization of $p$-Quinone Methides: Enantioselective Synthesis of Dibenzylic Boronates. ACS. Catal. 2016, 6, 442-446. https://doi.org/10.1021/acscatal.5b02742

${ }_{12}$ You, W.; Li, Y.; Brown, M. K. Stereoselective Synthesis of All-Carbon Tetrasubstituted Alkenes from In Situ Generated Ketenes and Organometallic Reagents. Org. Lett., 2013, 15, 1610-1613. https://doi.org/10.1021/ol400392r 